GEOLOGICAL SURVEY CIRCULAR 860

\title{
Estimates of Undiscovered Recoverable Conventional Resources of Oil and Gas in the United States
}

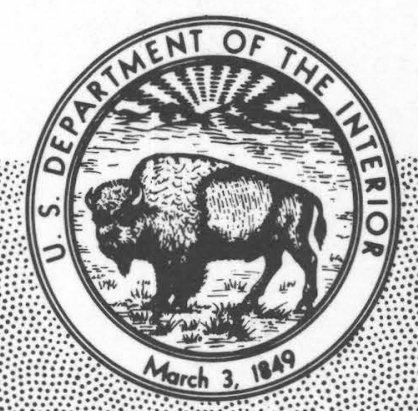





\section{Estimates of Undiscovered Recoverable Conventional Resources of Oil and Gas in the United States}

By G. L. Dolton, K. H. Carlson, R. R. Charpentier, A. B. Coury, R. A. Crovelli, S. E. Frezon,

A. S. Khan, J. H. Lister, R. H. McMullin,

R. S. Pike, R. B. Powers, E. W. Scott, and K. L. Varnes

GEOLOGICAL SURVEY CIRCULAR 860 
United States Department of the Interior

JAMES G. WATT, Secretary

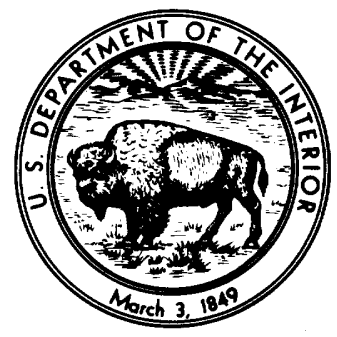

\section{Geological Survey}

Dallas L. Peck, Director

Library of Congress catalog-card No. 82-600010

Free on application to Branch of Distribution, U.S. Geological Survey, 604 South Pickett Street, Alexandria, VA 22304 
Summary.$\ldots \ldots \ldots \ldots \ldots \ldots \ldots \ldots \ldots \ldots \ldots \ldots \ldots$

Introduction. ......................

Acknowledgments.....................

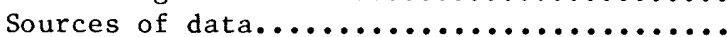

Commodities assessed..................

Definitions.........................

Role of technology and economics in

appraisal of recoverable resources....... 7

Region and province locations and

Geologic framework................... 8

Areas and volumes of sedimentary rocks..... 11

Methodology of resource appraisal........ 12

Review of general methods............ 12

Appraisal procedures for this report...... 14

Methodology for processing probabilistic

assessments of undiscovered hydro-

carbon resources................... 16

Summary of methodology............. 20

Calculation of resources of natural gas

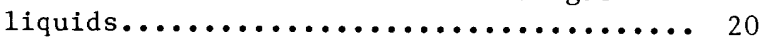

Calculation of inferred reserves......... 22 boundaries....................... 8

Estimates of petroleum resources.......... 26

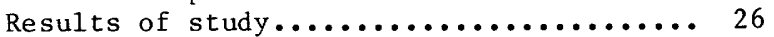

Comparison of recent hydrocarbon

resource estimates................. 29

Conclusions......................... 35

Selected references.................. 36

Appendixes

A. Aggregate probability distributions............... 41

B. Province index maps........... 74

C. Estimates of undiscovered recoverable oil and gas for onshore provinces........... 76

D. Estimates of undiscovered recoverable oil and gas for offshore provinces.......... 78

E. Estimated Federal ownership of oil and gas resources........ 80

F. Estimation of inferred plus indicated reserves for the United States, by D. H. Root....

ILLUSTRATIONS

Figure 1. Diagrammatic representation of discovered and undiscovered

Page recoverable quantities of crude oil and natural gas in the United States......... 3

2. Diagrammatic representation of petroleum resource classification............. 6

3. Maps showing petroleum Regions of the United States......... 9

4. Generalized tectonic map of North America............. 10

5. Map showing general areal distribution of the oil and gas fields of the United States.............. 11
Figures $\quad$ Page

6-12. Graphs showing:

6. Age range of principal producing and prospective reservoir rock units by petroleum Regions.............

7. Example of finding-rate curves showing extrapolation of exponential and hyperbolic curves..........

8. Typical conditional probability distribution of an undiscovered recoverable resource... 
Figure

9. Conditional probability
distribution of undis-
covered recoverable oil
for the North Atlantic
Shelf province..........

10. Probability distribution of undiscovered recoverable oil for the North Atlantic Shelf province.............

11. Probability distribution of undiscovered recoverable oil for Mid-Atlantic She1f province............

12. Aggregate probability distribution of undiscovered recoverable oil for the combined North Atlantic and Mid-Atlantic Shelf area...........

13-14. Maps showing estimated ranges and means of undiscovered recoverable resource by Region for: 13. Crude oil............... 26

8

\section{Figure} $15-16$.

$17-18$

$19-20$

Table 1. Production, reserves, and estimates of undiscovered recoverable resources of crude oil, natural gas, and natural gas liquids for the United States... 2

2. Estimates of minimum economic field sizes offshore......... 8

3. Estimated areas and volumes of sedimentary rocks by Region.....

$\begin{array}{ll} & \text { Tabl } \\ 2 & \\ 8 & \\ 13 & \end{array}$

14. Natural gas.............

Charts showing undiscovered

recoverable resources by

Region as percentage of the

total estimate for

the United States for:

15. Crude oil............ 28

16. Natural gas........... 29

Graphs showing estimates of

discovered and undiscovered

amounts of recoverable re-

sources by Region for:

17. Crude oil............ 30

18. Natural gas.......... 31

Graphs showing probability distributions of undiscovered recoverable resources for the United States for:

19. Crude oil............ 32

20. Natural gas.......... 32

Graphs showing selected estimates of undiscovered recoverable resources for the United States for:

21. Crude oil........... 33

22. Natural gas........... 34

34




\title{
Estimates of Undiscovered Recoverable Conventional Resources of Oil and Gas in the United States
}

\author{
By G. L. Dolton, K. H. Carlson, R. R. Charpentier, A. B. Coury, \\ R. A. Crovelli, S. E. Frezon, A. S. Khan, J. H. Lister, R. H. McMullin, \\ R. S. Pike, R. B. Powers, E. W. Scott, and K. L. Varnes
}

\section{SUMMARY}

In 1980, the U.S. Geological Survey (USGS) reappraised the undiscovered recoverable conventional resources of crude oil and natural gas in the United States. This investigation was in response to a national need for such estimates and took into account new geologic information and technology, economic changes, and new or refined methods of resource appraisal. The assessed resources were defined as those that could be extracted economically under price-cost relationships and technological trends prevailing at the time of the assessment. Undiscovered recoverable resources do not include quantities that may yet be found in new pay zones or extensions of existing fields. Also excluded from this assessement were resources from heavy oil deposits, tar deposits, oil shales, as well as gas in lowpermeablity "tight" reservoirs, gas occluded in coal, gas in geopressured shales and brines, and gas in natural gas hydrates (clathrates).

For this study, the United States was divided into 15 Regions--11 onshore and 4 offshore. These Regions correspond in general to those assessed in the USGS 1975 appraisal (Miller and others, 1975); however, the continental slopes were included in the present report, thereby increasing the offshore area assessed. The 15 Regions were further subdivided into 137 provinces that were the actual assessment units. Hawaii was not included because its volcanic terrane was not considered prospective for hydrocarbons.

The assessments of undiscovered recoverable oil and gas were based fundamentally upon analysis and review of the province petroleum geology, exploration history, volumetric-yield determinations, finding-rate studies, and structural analyses. Because of the uncertainty in estimating undiscovered resources, the reported quantities include a range of values that correspond to different probability levels. Subjective probability procedures were used in their derivation.

The undiscovered recoverable conventional oil resources for the United States are estimated to range from 64.3 to 105.1 billion barrels with a mean estimate of 82.6 billion barrels (table 1). Assessed gas resources range from 474.6 to 739.3 trillion cubic feet with a mean estimate of 593.8 trillion cubic feet (table 1). Each range corresponds to 95 percent and 5 percent probabilities of more than the respective amounts.

When compared with the USGS estimates of 1975, the mean estimate of oil for the entire United States has changed little, whereas the mean estimate of natural gas has increased. In making such a comparison, however, the reader should recognize that resources of the continental slopes are included in the current assessment, but were not included in the 1975 report.

Figure 1 shows the relationship between undiscovered recoverable quantities and those quantities that already have been found. For oil, the mean estimate of undiscovered resources is about 47 percent of what has been found. For natural gas, the mean estimate of undiscovered resources is 63 percent of what has been found.

\section{INTRODUCTION}

This report presents a new appraisal of the undiscovered recoverable conventional resources of oil and gas in the United States. The appraisal, which was made in mid-1980 following an intensive period of study, incorporated data that were not available at the time of the previous USGS estimates (Miller and others, 1975). The new appraisals were based on new geologic information, results of continuing petroleum exploration, advances in petroleum 
Table 1.--Production, reserves, and estimates of undiscovered recoverable resources of crude oil, natural gas, and natural gas liquids for the United States

[Al1 tabulated values are rounded numbers; therefore, values for production and reserves and for means of undiscovered resources, all of which are additive, may not be precisely so. Neg1., negligible, less than or equal to 0.05 billion barrels of oil or 0.05 trillion cubic feet of gas; NA, not applicable; NE, not estimated]

\begin{tabular}{|c|c|c|c|c|c|c|c|}
\hline \multirow[b]{2}{*}{ Area } & \multirow[b]{2}{*}{$\begin{array}{l}\text { Cumulative } \\
\text { production }\end{array}$} & \multicolumn{3}{|c|}{ Identified resources ${ }^{l}$} & \multicolumn{2}{|c|}{ Undiscovered recoverable } & resources \\
\hline & & $\begin{array}{l}\text { Measured } \\
\text { reserves }\end{array}$ & $\begin{array}{l}\text { Indicated } \\
\text { reserves }\end{array}$ & $\begin{array}{l}\text { Inferred } \\
\text { reserves }\end{array}$ & $\begin{array}{l}\text { Low } \\
{ }_{F_{95}}\end{array}$ & $\begin{array}{l}\text { High } \\
3_{F_{5}}\end{array}$ & Mean \\
\hline \multicolumn{8}{|l|}{ Onshore } \\
\hline 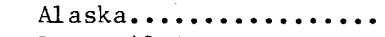 & 1.2 & 8.7 & 0 & 5.0 & 2.5 & 14.6 & 6.9 \\
\hline \multicolumn{8}{|l|}{ Offshore } \\
\hline 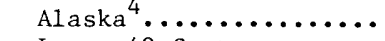 & 0.7 & 0.2 & 0 & 0.1 & 4.6 & 24.2 & 12.2 \\
\hline Lower 48 States........ & 7.5 & 3.0 & Negl. & 1.4 & 8.7 & 25.1 & 15.8 \\
\hline Entire offshore....... & 8.2 & 3.1 & Negl. & 1.5 & 16.9 & 43.5 & 28.0 \\
\hline Entire United States..... & 120.7 & 27.8 & 3.6 & 23.4 & 64.3 & 105.1 & 82.6 \\
\hline
\end{tabular}

Natural gas (trillion cubic feet)

\begin{tabular}{|c|c|c|c|c|c|c|c|}
\hline \multicolumn{8}{|l|}{ Onshore } \\
\hline Alaska............... & 1.2 & 30.0 & $\mathrm{NA}$ & 4.4 & 19.8 & 62.3 & 36.6 \\
\hline Lower 48 States......... & 519.3 & 123.3 & NA & 132.1 & 288.6 & 525.9 & 390.2 \\
\hline Entire onshore........ & 520.6 & 153.3 & $\mathrm{NA}$ & 136.5 & 322.5 & 567.9 & 426.8 \\
\hline \multicolumn{8}{|l|}{ Offshore } \\
\hline Alaska ${ }^{4} \ldots \ldots \ldots$ & 0.6 & 2.0 & NA & 1.2 & 33.3 & 109.6 & 64.6 \\
\hline Lower 48 States........ & 56.8 & 36.3 & $\mathrm{NA}$ & 39.8 & 66.1 & 148.2 & 102.4 \\
\hline Entire offshore........ & 57.5 & 38.2 & NA & 41.0 & 117.4 & 230.6 & 167.0 \\
\hline Entire United States..... & 578.0 & 191.5 & NA & 177.5 & 474.6 & 739.3 & 593.8 \\
\hline
\end{tabular}

Natural gas liquids (billion barrels)

\begin{tabular}{llllllll}
\hline Entire United States..... & 19.1 & 5.7 & NA & 4.8 & NE & NE & 17.7 \\
\hline
\end{tabular}

${ }^{1}$ Cumulative production and reserves are as of December 31,1979 . Production and reserve figures were derived from API and AGA data (American Petroleum Institute, American Gas Association, and Canadian Petroleum Association, 1980), except for California where production and reserve data were taken from the California Division of 011 and Gas (1980) and the U.S. Geological Survey (Kalil, 1980).

${ }^{2}$ Does not include gas in storage.

${ }^{3} \mathrm{~F}_{95}$ denotes the 95 th fractile; the probability of more than the amount $\mathrm{F}_{95}$ is 95 percent.

$\mathrm{F}_{5}$ is defined similarly. Fractile values are not additive.

${ }^{4}$ Includes quantities considered recoverable only if technology permits their exploitation beneath Arctic pack ice-a condition not yet met.

technology, changes in economic conditions, and refined methods of resource appraisal.

The primary purpose of this report is to present estimates of the quantities of oil and gas that may be available for discovery and recovery. Secondary objectives are to describe briefly the geologic and mathematical methodologies used in the analyses and to provide an historical context for review of the results. Preliminary results of this study were released in USGS Open-File Report 81-192 (Dolton and others, 1981).

The United States was divided into 137 provinces, which included 80 onshore provinces and 57 offshore provinces on the continental shelves and slopes. Estimates of undiscovered recoverable oil and gas resources were made for each province. Each evaluation involved the determination, from a geologic viewpoint, of the likelihood of the province having recoverable oil and gas, and the estimation of possible quantities of undiscovered recoverable oil and gas. Subjective probability methods were used.

Both English and metric units are used in this report. For resource quantities English units are used exclusively. For most other quantities (such as drilling depths, areas, volumes) the traditionally used English units are given with metric equivalents in parentheses. For water depths, metric units are 


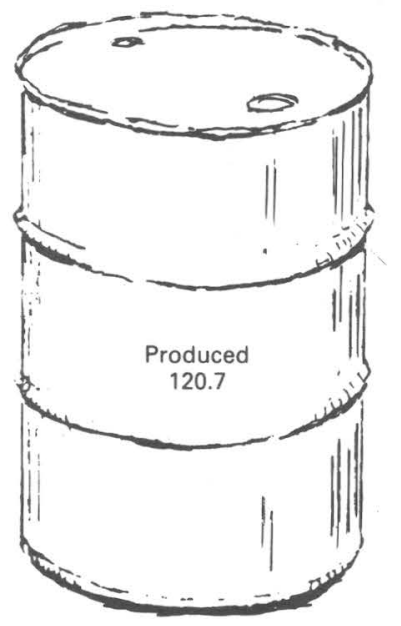

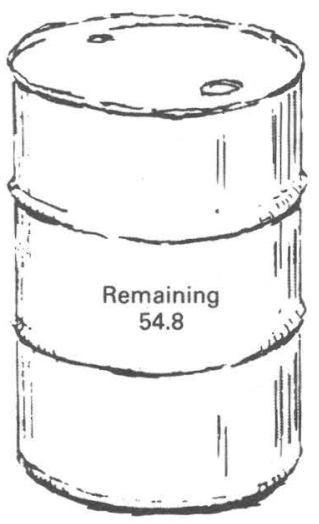

DISCOVERED

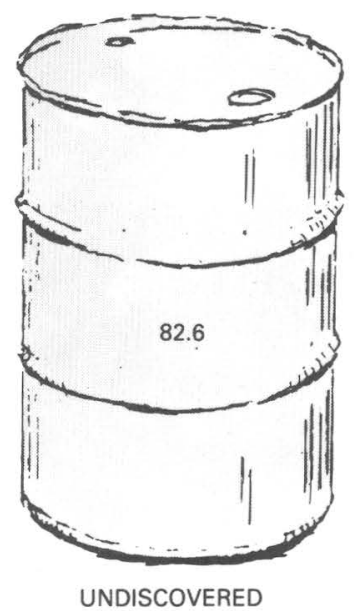

CRUDE OIL, IN BILLON BARRELS

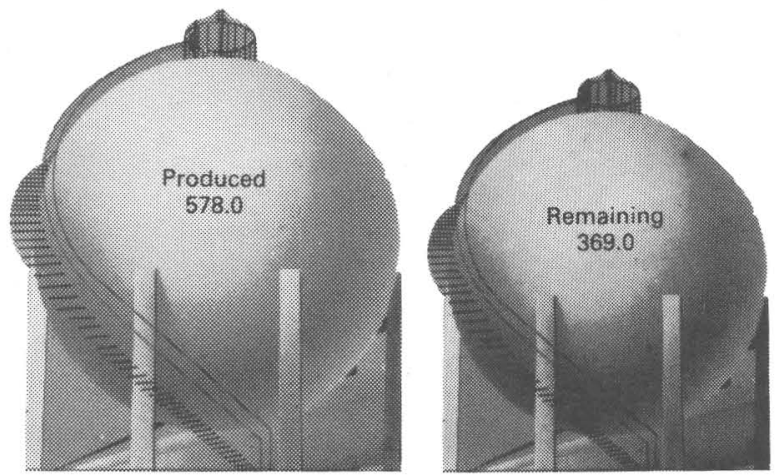

DISCOVERED

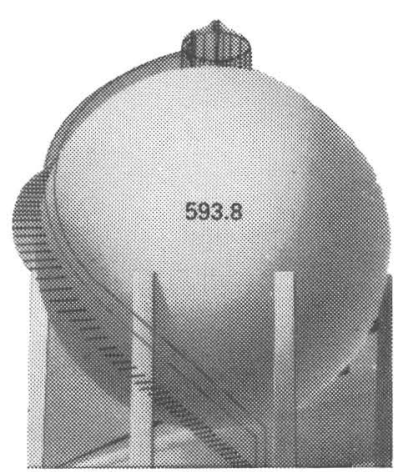

UNDISCOVERED

NATURAL GAS, IN TRILLION CUBIC FEET

Figure 1.--Discovered and undiscovered recoverable quantities of crude oil and natural gas in the United States. Undiscovered values are mean estimates. Crude oil in billion barrels; total natural gas in trillion cubic feet. 
more traditional and are used singly or with English equivalents.

\section{ACKNOWLEDGMENTS}

Integration of a vast quantity of information into this assessment of the Nation's petroleum resources required the involvement of many USGS scientists. State Geologists were invited through W. L. Fisher, Chairman, Liaison Committee of the Association of State Geologists, to participate. In addition to the authors, fifty USGS geologists aided in the data gathering and appraisal process. They were responsible for assembling data from 91 of the 137 provinces assessed. We wish to thank the following people for their contributions:

\section{U.S. GEOLOGICAL SURVEY}

\section{Geologic Division}

Branch of Alaskan Geology,

Mento Park, Catifomia

W. P. Brosgé

M. Churkin, Jr.

R. L. Detterman

A. A. Grantz

G. Plafker

Anchorage, Alaska

C. G. Mul1

Branch of Pacific-Arctic Marine Geology,

Menlo Park, Califomia

S. H. Clark, Jr.

A. K. Cooper

J. K. Crouch

M. S. Marlow

S. D. May

D. W. Scholl

P. D. Snavely, Jr.

J. G. Vedder

R. E. von Huene

Seattie, Washington

T. H. McCulloh

Branch of Atzantic-Gulf Coast Marine Geology, Corpus Christi, Texas

R. G. Martin

Woods Hole, Massachusetts

W. P. Dillon

J. A. Grow

J. S. Schlee

Branch of 0 it and Gas Resources, Cincinnati, Ohio

R. C. Kepferle

Corpus Christi, Texas

R. Q. Foote

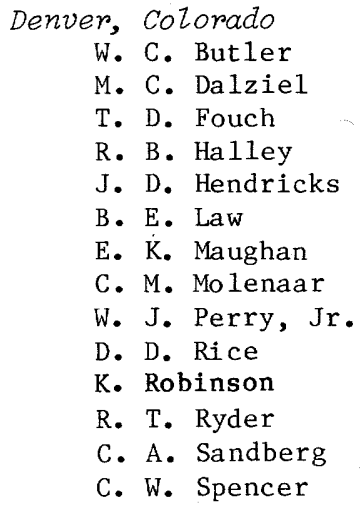

Missoula, Montana

J. A. Peterson

Rapid City, South Dakota

J. E. Fox

Reston, Virginia

K. C. Bayer

W. dewitt, Jr,

L. D. Harris

Woods Hole, Massachusetts

M. M. Ba 11

Branch of Sedimentary Minerals, Denver, Colorado

R. J. Hite

The following individuals also contributed as advisors, consultants, or participants in the appraisal process:

\section{U.S. GEOLOGICAL SURVEY}

\section{Geologic Division}

Branch of Pacific-Arctic Marine Geology, Mento Park, Califomia

D. S. McCulloch 
Branch of Paleontology and Stratigraphy, Woods Hole, Massachusetts

$$
\text { C. W. Poag }
$$

Branch of oil and Gas Resources, Reston, Virginia R. E. Mattick

\section{Conservation Division}

Anchorage, Alaska

I. F. Palmer, Jr.

Los Angeles, Califomia

D. G. Griggs

F. L. Webster

Metairie, Louisiana

F. T. Bryan

J. Hewitt

J. R. Pearcy

Reston, Virginia

R. A. Kahler

Washington, D.C.

R. V. Amato

R. D. Higgens

S. S. Jacobson

F. W. Lishman

E. K. Simonis

STATE OF CALIFORNIA, DEPARTMENT OF CONSERVATION Sacramento, Califomia

W. F. Guerard

U.S. DEPARTMENT OF ENERGY, OFFICE OF APPLIED ANALYSIS

Dalzas, Texas

T. M. Garland

\section{STATE OF LOUISIANA, OFFICE OF CONSERVATION}

Baton Rouge, Louisiana

R. T. Sutton,

Commissioner of Conservation

OKLAHOMA GEOLOGICAL SURVEY

Norman, OkZahoma

W. E. Harrison

Our technical support staff helped in the preparation of this report. J. H. Yenowine, Q. A. Wright, and B. L. Lane, provided valuable assistance in computing production statistics, planimetry, computer processing, the development of finding-rate curves, and other tasks necessary for the completion of this report. J. S. Wesley made literature searches and obtained references. D. D. Fox and D. K. Hobbs typed the manuscript. Tom Kostick provided drafting expertise in preparation of illustrations. In addition, we are indebted to J. D. Megeath and N. E. Pence for writing several computer programs, including graphics routines, and for revising a program originally based on the ideas of G. M. Kaufman, Massachusetts Institute of Technology. We also wish to thank T. S. Dyman for his assistance in data retrieval.

We particularly wish to thank the Conservation Division, U.S. Geological Survey, which made available unpublished material, including proprietary data, for many offshore areas.

\section{SOURCES OF DATA}

Primary sources of daca for this study were direct contributions of U.S. Geological Survey geologists; published geologic information; published statistical data on petroleum exploration, reserves, and production; and unpublished U.S. Geological Survey material.

The "Selected References" section lists the major published sources used for the nation as a whole; however, many significant reports and maps pertaining to specific regions are not included in this listing. Statistical data on production, reserves, and exploratory drilling were obtained primarily from the annual volumes on reserves and production of the American Petroleum Institute (API), American Gas Association (AGA), and Canadian Petroleum Association (CPA) (1967-1980), and from annual State statistical publications. Also used extensively were the oil and gas development yearbooks of the International 0il Scouts Association (1945-1978).

Maps used on a national scale were the Geologic Map of the United States (King and Beikman, 1974), the Tectonic Map of North America (King, 1969), the Geothermal Gradient Map of North America (Geothermal Survey of North America Subcommittee of the American Association of Petroleum Geologists Research Committee, 1976), the Basement Rock Map of the United States exclusive of Alaska and Hawaii (Bayley and Muehlberger, 1968), the Oil and Gas Fields of the United States exclusive of Alaska and Hawaii (V1issides and Quirin, 1964), and the Terra Graphics' $\mathrm{Oil}$ and Gas Production Map of the United States (Smith, 1977). The National Atlas (U.S. Geological Survey, 1970) and land status and mineral status maps from the Bureau of Land Management were useful in the estimation of Federal and other ownership of oil and gas.

Computer data bases included the Petroleum Information Corporation's We1l History Control System and the Petroleum Data System. Some field and pool data were supplied by the office of Applied Analysis, U.S. Department of Energy, Dallas, Texas.

\section{COMMODITIES ASSESSED}

Commodities included in this appraisal are crude oil, natural gas, and natural gas liquids that exist in conventional reservoirs. Crude oil is a mixture of hydrocarbons present in a liquid state in underground reservoir rocks and remaining in a liquid state as it is produced 
from wells. Natural gas is a mixture of gaseous hydrocarbons classified by occurrence into the following categories:

Associated gas--free natural gas, occurring as a gas cap, in contact with and above an oil accumulation within the reservoir;

Dissolved gas--natural gas dissolved in crude oil within the reservoir; and

Non-associated gas--natural gas that is not associated with or not in contact with crude oil within a reservoir.

Natural gas liquids (NGL) are "those portions of reservoir gas which are liquefied at the surface in lease separators, field facilities, or gas processing plants. Natural gas liquids include but are not limited to ethane, propane, butanes, pentanes, natural gasoline, and condensate" (American Petroleum Institute, 1976, p. 6). Both oil and natural gas normally include small quantities of various nonhydrocarbon impurities. Amounts of oil and gas are reported as standard stock tank barrels of crude oil (42 gallons per barre1) and standard cubic feet of gas ( 14.73 pounds per square inch atmosphere and $\left.60^{\circ} \mathrm{F}\right)$, respectively.

We have excluded unconventional resources from this assessment. Eliminated, therefore, were resources from heavy oil deposits, tar deposits, and oil shales; as well as gas in lowpermeability ("tight") reservoirs, gas occluded in coal, gas in geopressured shales and brines, and gas in natural gas hydrates (clathrates). However, small quantities of gas in lowpermeability reservoirs and limited quantities of heavy oil were incorporated as reserves and production in this report because they were not separated in the published production and reserve data sources.

Estimates of undiscovered crude oil and natural gas are as of $\mathrm{mid}-1980$.

\section{DEFINITIONS}

Resource definitions published by the U.S. Bureau of Mines and the U.S. Geological Survey (McKelvey, 1973; U.S. Bureau of Mines and U.S. Geological Survey, 1976, 1980) have been modified to apply specifically to crude oil, natural gas, and natural gas liquids. In some instances, definitions published by API (1976) were used with modification. The principal terms used in the present study are defined as follows, and, where appropriate, are identified in figure 2:

Resources.--Concentrations of naturally occurring liquid or gaseous hydrocarbons in the Earth's crust, some part of which is currently or potentially economically extractable.

Economic (commercial) resources.-Those resources, both identified and undiscovered, that are economically extractable. In this study, price-cost relationships and technological trends prevailing at the time of assessment (1980) were assumed. Specifically excluded are quantities that may be technically extractable but not economically so. Therefore, excluded are deposits that are too small, too dispersed or too remote to be presently economic, and those portions of economic deposits that are non-extractable in a technologic sense.

Recoverable resources.--Identical to economic resources.

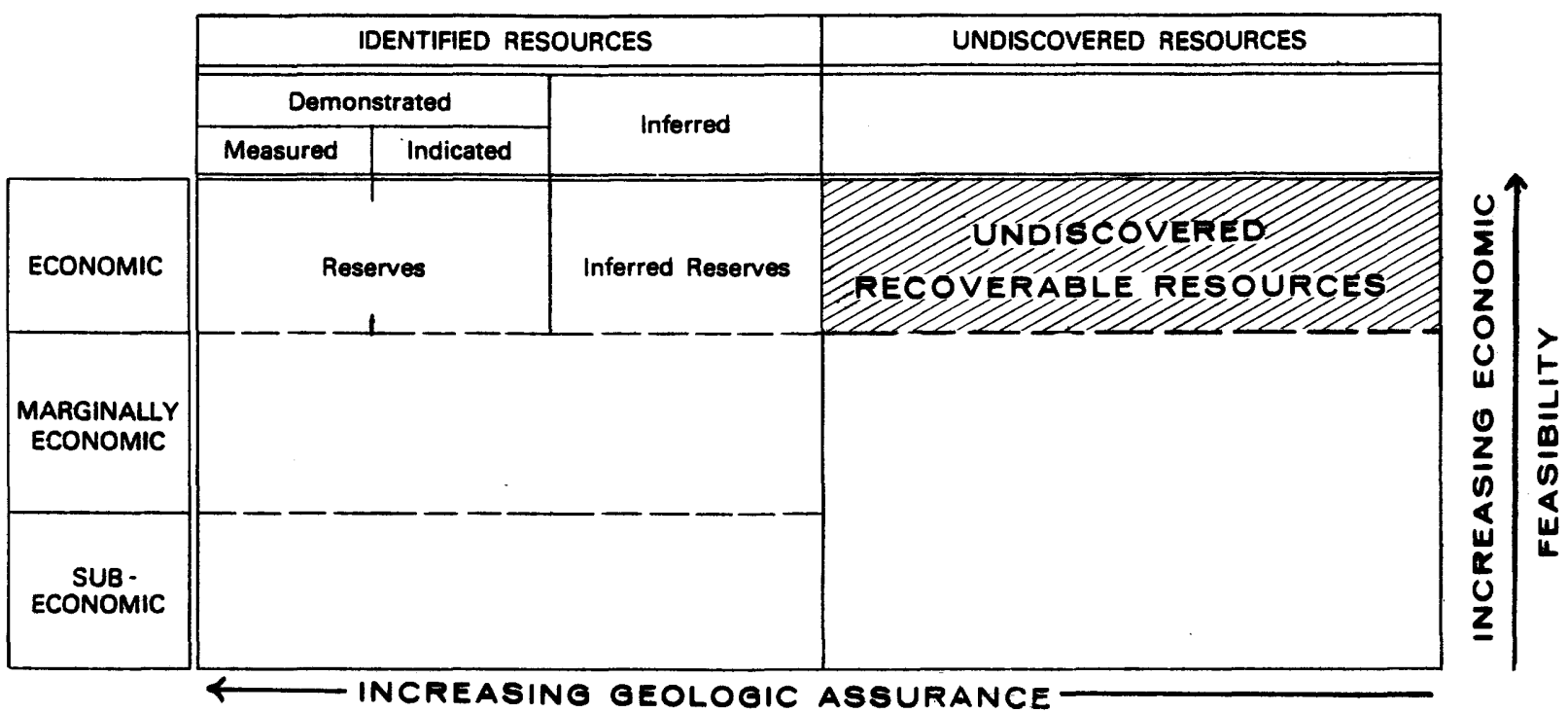

Figure 2.--Petroleum resource classification (modified from U.S. Bureau of Mines and U.S. Geological Survey, 1976, 1980). Shaded area indicates the undiscovered recoverable resources estimated in the present study. 
Marginally economic resources.--Resources not presently recoverable because of technologic and (or) economic factors, but that may become recoverable in the future. They are that part of the resources intermediate between the economic and subeconomic categories (fig. 2).

Subeconomic resources.--Resources that have an even more remote likelihood of extraction than do marginally economic resources. They are considered to be the largely unextractable portion of the original oil and gas in-place. Some part eventually may become recoverable as a result of major changes in technology and economic conditions; however, significant portions may never be recoverable.

Identified resources.--Resources whose location and quantity are known or are estimated from specific geologic evidence and that include economic, marginally economic, and subeconomic components. Identified resources also can be subdivided (fig. 2) into measured, indicated, and inferred resources, expressing varying degrees of geologic certainty.

Measured reserves.--That part of the economic identified resource that is estimated from geologic evidence supported directly by engineering measurements. Measured reserves here are equivalent to proved reserves as defined by $\operatorname{API}(1976$, p. 1).

Indicated reserves.--Reserves equivalent to API indicated additional reserves, that are defined as economic reserves in "known productive reservoirs in existing fields expected to respond to improved recovery techniques such as fluid injection where (a) an improved recovery technique has been installed but its effect cannot yet be fully evaluated; or (b) an improved technique has not been installed but knowledge of reservoir characteristics and the results of a known technique installed in a smiliar situation are available for use in the estimating procedure." (API, 1976, p. 1, 2.)

Inferred reserves.--That part of the identified economic resource that will be added to known fields through extensions, revisions, and new pay zones. (See p. 22 and Appendix F for derivation of inferred reserves used in this study.)

Undiscovered resources.--Resources, outside of known fields, estimated from broad geologic knowledge and theory . Also included are resources from undiscovered pools that occur as unrelated accumulations controlled by distinctly separate structural features and (or) stratigraphic conditions within areas of known fields.

Oil or gas in-place.--The total oil or natural gas that is in underground reservoir rock without qualification as to what portion may be considered either currently or potentially extractable. $0 i 1$ or gas in-place is essentially equivalent to total resources.

Pool.--A discrete natural accumulation of oil or gas in an underground reservoir, confined by barriers of water or impermeable rock, and characterized by a single pressure system. Some reporting agencies may define each pool as a separate field, as is done in Texas.

Field.--A single pool or multiple pools all grouped on, or related to, a single structural and (or) stratigraphic feature. Individual pools in a single field may be separated vertically by impervious strata or laterally by local geologic barriers.

\section{ROLE OF TECHNOLOGY AND ECONOMICS IN APPRAISAL OF RECOVERABLE RESOURCES}

This study, which assesses the undiscovered recoverable hydrocarbon potential of the United States, considers only conventional accumulations of oil and gas. In production from conventional reservoirs, there are certain technologic and economic limitations to the amount of oil or gas in-place that can be recovered. Recovery of oil from a pool generally is limited to less than 60 percent of what is in place, and recovery of gas to less than 90 percent. On a national scale, recovery factors for oil and gas average about 32 percent and 80 percent, respectively.

Additional technologic and economic constraints apply to the conditions under which exploration and production can take place. These conditions include the depth of drilling into the Earth's crust, the water depth offshore, availability of transportation and proximity to markets, and ice and other harsh physical environmental conditions. In addition, production rate and life expectancy of the reservoir are important factors. Drilling onshore now has reached depths in excess of 30,000 ft $(9,144 \mathrm{~m})$, and deepest reported production is at $26,518 \mathrm{ft}(8,083 \mathrm{~m}$ ) (World Oil, $1981 \mathrm{a}, \mathrm{b})$. Industry exploratory wells have been drilled in water depths approaching 5,000 ft $(1,524 \mathrm{~m})$; a drilling vessel is expected to be available soon to drill in water depths to $13,000 \mathrm{ft}(3,962 \mathrm{~m})$ and to depths of $20,000 \mathrm{ft}$ $(6,096 \mathrm{~m})$ below the sea floor. To date, the deepest water where production has been established is slightly more than $1,000 \mathrm{ft}$ (305 m). Continued extension of deep-water drilling and production technology can be expected as a result of current design and research programs.

In estimating amounts of undiscovered recoverable (economic) oil and gas resources, certain assumptions must be made about economics and technology. We assumed that undiscovered resources of oil and gas will be recoverable under conditions represented by a continuation of price-cost relationships and technological trends that prevailed at the time of the assessment (1980). However, significant changes in price-cost relationships or fundamental changes in technology would affect estimates of recoverable resources.

Onshore, the economic and technologic conditions assumed permitted the appraisal of recoverable resources on the basis of the size and type of fields that historically have been found, developed, and produced. of fshore, 
Table 2.--Estimates of minimum economic field sizes offshore

[Gas-field sizes for the Gulf of Mexico and all oil-field sizes were provided by D. E. Kash, Conservation Division, U.S. Geological Survey, 1980, in a written communication. Non-associated gas-field sizes other than for the Gulf of Mexico were derived from the oil-field sizes by using a British thermal unit (BTU) equivalent of 6000 cubic feet of gas to one barrel of oil]

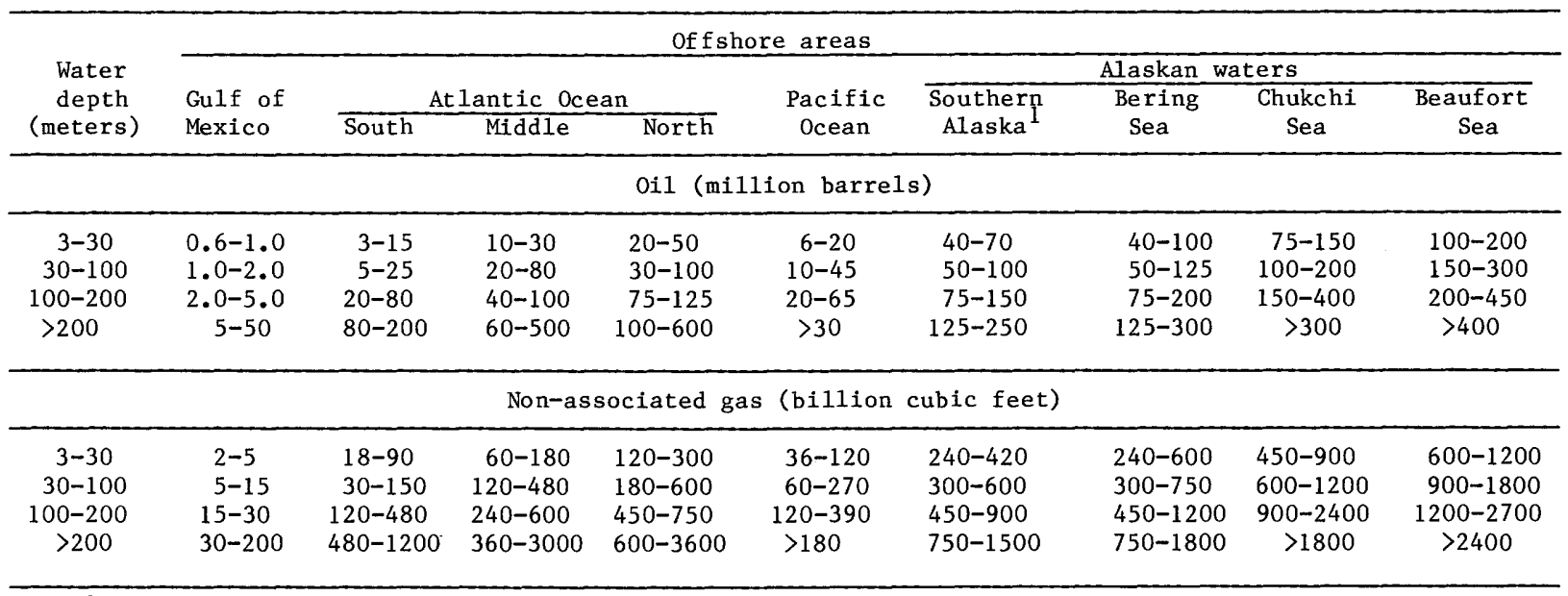

\footnotetext{
${ }^{1}$ Gulf of Alaska, Kodiak, lower Cook Inlet, Shelikof Strait.
}

recoverability often is uncertain due to the severe technologic and economic constraints imposed by the operating conditions. For guidelines, minimum field sizes for undiscovered recoverable resources offshore were arbitrarily assumed to be those summarized in table 2. In offshore northern Alaska, although economic field-size thresholds are indicated on table 2, even large accumulations beneath Arctic pack ice do not appear to be currently exploitable, although technologic advance may permit their development in the future.

\section{REGION AND PROVINCE LOCATIONS AND BOUNDARIES}

Regions and provinces were established to provide a basis for systematic appraisal. The 15 Regions in this report (fig. 3), 11 onshore and 4 offshore, coincide in part with major geographic elements and are similar to those Regions used by Cram (1971) and by Miller and others (1975). The Regions in the present report were divided into 137 individual provinces that were the actual appraisal units.

Province boundaries were based on natural geologic entities and may include a single dominant structural element or a number of contiguous elements. These boundaries follow State and county lines where possible, thus facilitating the use of production, reserve, and other data reported for political units by various State and Federal agencies and private compilers. Provinces were named for a structural, physiographic, or geographic feature within the province.
Offshore, province boundaries were drawn between shelf and slope at $200 \mathrm{~m}(656 \mathrm{ft})$ of water depth. Provinces of the continental slope extend seaward from a water depth of $200 \mathrm{~m}$ (656 $\mathrm{ft})$ to a depth of $2,400 \mathrm{~m}(7,874 \mathrm{ft})$ off Alaska and $2,500 \mathrm{~m}(8,202 \mathrm{ft})$ off the conterminous United States, unless the base of slope is at a shallower water depth.

With reference to the international boundaries of the offshore regions, the United States has not yet resolved its offshore boundaries with its neighboring States. For purposes of this report, certain arbitrary assumptions had to be made about the extent of areas potentially subject to United States jurisdiction. The lines used in preparing this report are for purposes of illustration only, and do not necessarily reflect the position or views of the United States with respect to the location of the offshore boundaries between the United States and other States concerned. The United States expressly reserves its rights, and those of its nationals, in all areas in which the offshore boundary has not been resolved, and these illustrative lines are used without prejudice to such rights.

\section{GEOLOGIC FRAMEWORK}

The distribution of oil and gas resources in the United States is best understood within the framework of the geology of the North American continent. In essence, the continent consists of a relatively stable interior surrounded by zones of more highly deformed 
rocks (fig. 4). The Canadian Shield is an outcrop of the old, tectonically stable rocks that form the core of the continent. These igneous and metamorphic rocks are not prospective for hydrocarbons. In the Central Stable Interior, similar crystalline rocks are overlain by a relatively thin cover of sedimentary rock that fills a number of structurally uncomplicated basins separated by broad arches. Regional deformation of the platform formed by these sedimentary rocks occurs in the Colorado Plateau and in parts of the Rocky Mountain System. Marginal basins of the Central Stable Interior tend to be deeper and structurally more complex than are those of the interior.
Belts of rock deformed by intense folding and thrusting ring the central platform. These are the Cordilleran thrust belt that stretches from Alaska to Mexico, the Appalachian thrust be1t, the Ouachita thrust belt, and the Marathon thrust belt (fig. 4).

East of the Appalachian thrust belt are the crystalline rocks of the Piedmont. Mesozoic and Cenozoic sedimentary rocks of the Atlantic coastal plain lap onto the Piedmont forming a wedge of sedimentary rocks that thickens seaward along most of the Atlantic margin from a few hundred feet to more than 40,000 ft $(12,192$ m). Mesozoic and Cenozoic sedimentary rocks also lap onto the Marathon and Ouachita thrust belts and form the Gulf Coastal Plain. These

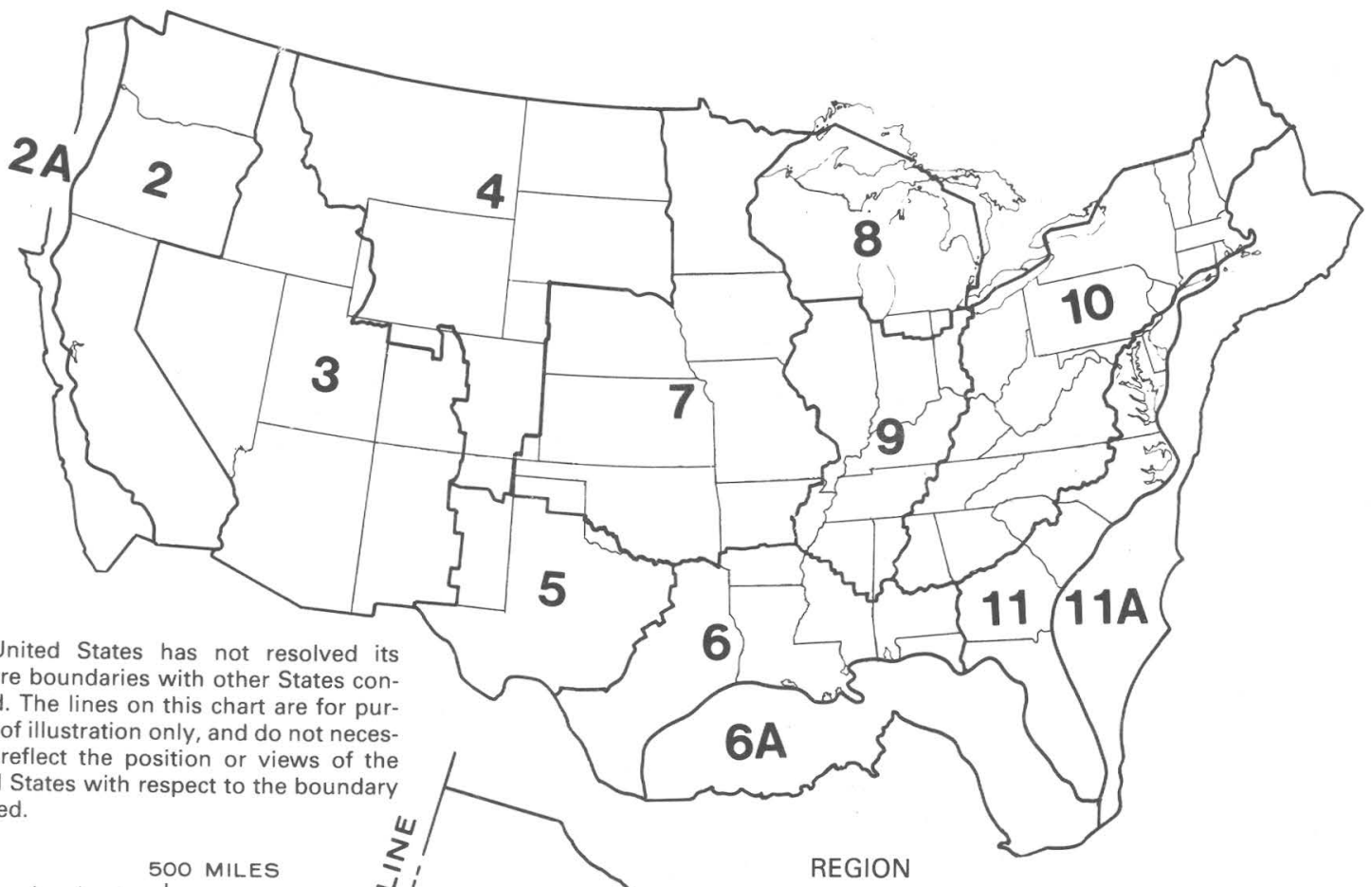

The United States has not resolved its offshore boundaries with other States concerned. The lines on this chart are for purposes of illustration only, and do not necessarily reflect the position or views of the United States with respect to the boundary involved.
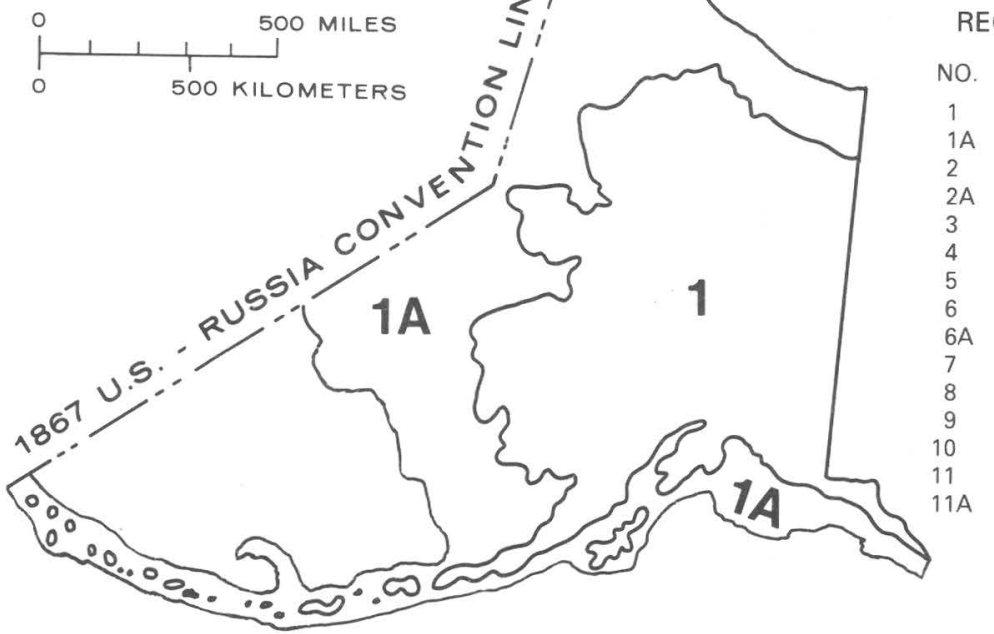

NO. NAME

1 Alaska

A Alaska offshore

Pacific Coast

Pacific Coast offshore

Colorado Plateau and Basin and Range

Rocky Mountains and Northern Great Plains

West Texas and Eastern New Mexico

Gulf Coast

Gulf of Mexico

Mid-continent

Michigan Basin

Eastern Interior

Appalachians

Atlantic Coast

Atlantic Coast offshore

Figure 3.--Petroleum Regions of the United States. 
younger rocks thicken southward into the Gulf of Mexico.

West of the Cordilleran thrust belt, the major structural or physiographic elements are the Basin and Range, parts of the Rocky Mountain System, and the Pacific Margin System. The complex structures of this part of the continent indicate that it has been tectonically active through much of geologic time.

Alaska is divided into two major structural and stratigraphic elements. The northern element consists of the Brooks Range, which is part of the Cordilleran thrust belt, and all areas north to the Arctic Ocean. The southern element includes all of Alaska south of the Brooks Range and has a different and more complex geologic history than does the northern element.

Areas of the United States that have produced oil and gas are shown in figure 5 . Ages of productive and prospective rocks in each Region are shown in figure 6. The Central Stable Interior (Regions 5, 7-9, and parts of 4 and 10) produces mainly from relatively old rocks of Paleozoic age. However, toward the western part of the Interior (parts of Regions 3 and 4) petroleum from some of the intermontane basins is produced both from the older rocks of

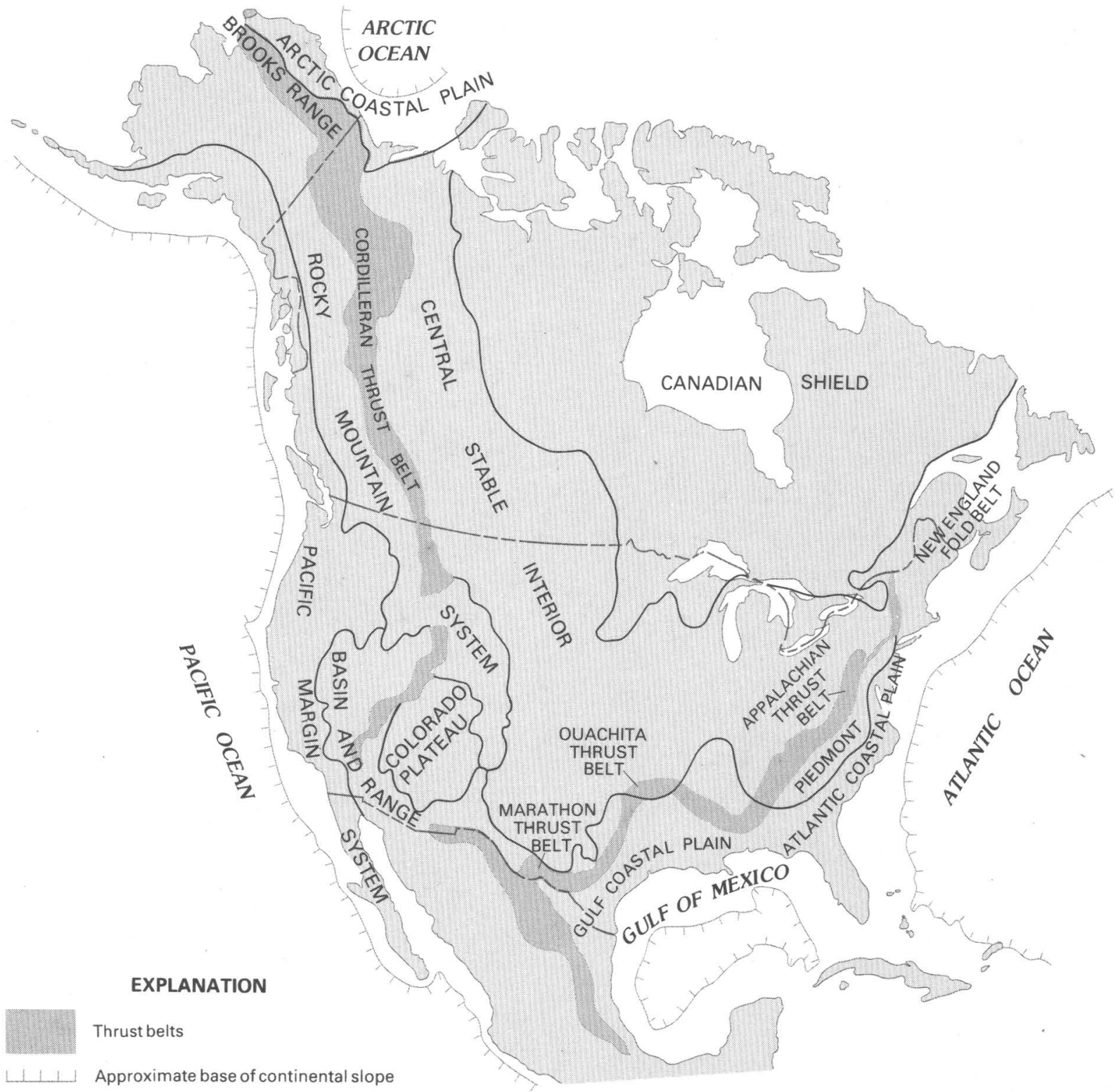

Figure 4.--Generalized tectonic map of North America. (Modified from King and Edmonston, 1972; and Hayes, 1976.) 
Paleozoic age and from younger rocks of Mesozoic and Cenozoic age.

Intense exploration for hydrocarbons in the thrust belts is relatively recent, but since 1975 substantial discoveries in Paleozoic and Mesozoic rocks have been made in the WyomingUtah-Idaho area. The Appalachian, Marathon, and Ouachita thrust belts are being actively explored.

A thick sequence of Mesozoic and Cenozoic sedimentary rocks characterizes both the Gulf and Atlantic margins. In the Gulf Coastal Plain (Region 6) and the adjoining Gulf of Mexico, these rocks have produced large quantities of hydrocarbons. Other than peninsular Florida, the Atlantic margin (Regions 11 and $11 \mathrm{~A}$ ) has not produced commercial amounts of petroleum to date; however, recent discoveries of gas and some oil have been made in Mesozoic rocks in the offshore mid-Atlantic Baltimore Canyon area.

A series of productive sedimentary basins extends from New Mexico to Montana within the Rocky Mountain System and the Colorado Plateau (parts of Regions 3 and 4). Hydrocarbon production in this area is from rocks of Paleozoic through Cenozoic age. Except for the rich Cenozoic basins in California, there is little production through much of the far western United States.

Alaska's production is from two major areas. Cook Inlet, in southern Alaska, produces from rocks of Cenozoic age, and the Arctic coastal plain of the North Slope, which includes the supergiant Prudhoe Bay Field, produces from rocks of Paleozoic, Mesozoic, and Cenozoic age.

\section{AREAS AND VOLUMES OF SEDIMENTARY ROCKS}

Areas and volumes of sedimentary rocks were determined for each province because the character, amount, and distribution of sedimentary fill in basins are fundamental factors relating to hydrocarbon potential. Some analytical procedures also are dependent upon such rock areas and volumes. Rocks that are deformed or altered to the point of being nonproductive for oil or gas were considered "basement" and were excluded. Igneous rocks were excluded except where they occur as incidental interlayers and intrusions. Areas and volumes of sedimentary rocks for the Regions of the United States are shown on table 3.

Rocks deeper than $30,000 \mathrm{ft}(9,144 \mathrm{~m})$ were excluded from these tabulations on the basis of

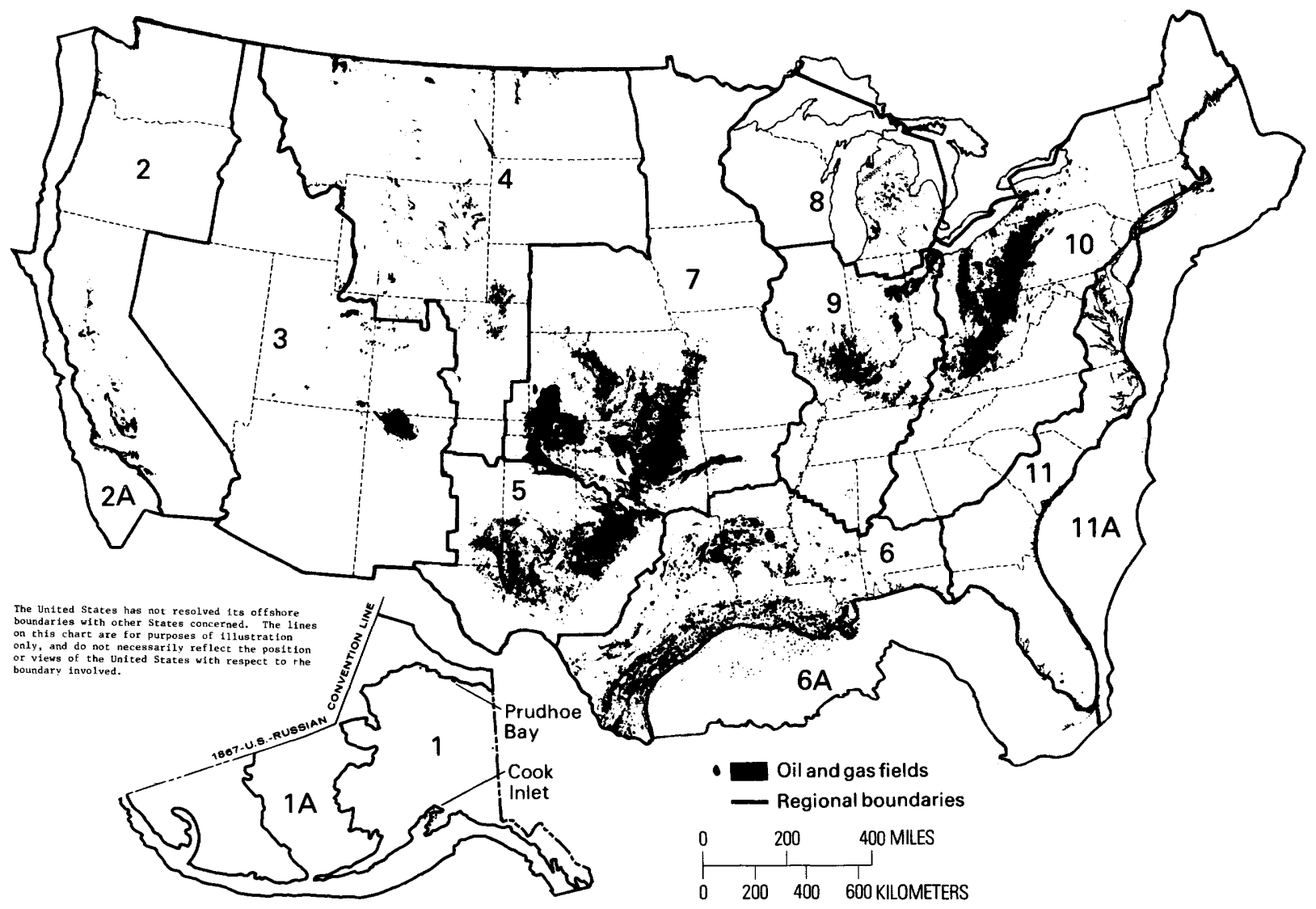

Figure 5.--General areal distribution of oil and gas fields in the United States. (Modified from V1issides and Quirin, 1964.) Names of numbered Regions are given in figure 3. 
limiting factors of economics and drilling technology and the general degradation of reservoirs at depth. All calculated volumes of sedimentary rocks were regarded as having petroleum potential, qualified by such geologic factors as reservoir quality, ability to generate hydrocarbons, and trapping potential.

\section{METHODOLOGY OF RESOURCE APPRAISAL}

\section{Review of general methods}

Many methods have been developed for estimating undiscovered petroleum resources. The methods differ greatly with respect to strengths, weaknesses, amount of information needed, and applicability of results. There are various amounts of overlap between the methods and sometimes several methods are used in conjunction. The five major categories of resource appraisal methods are as follows:
1. Extrapolation of Historical Trends

These methods use statistical procedures to predict future discoveries by extrapolation of past performances. The most commonly used historical statistics are finding rates, that relate the discovered volume of hydrocarbons to the exploratory footage drilled, or the number of exploratory wells, or time. Hubbert (1974) and Moore (1966) used techniques of this category.

\section{Areal- or Volumetric-yield Methods}

These methods involve the calculation of amounts of discovered hydrocarbon per unit area or volume of rock in well-explored districts and application of these ratios to areas or volumes of rock in less-explored districts. Variation among these approaches is due primarily to different assumptions

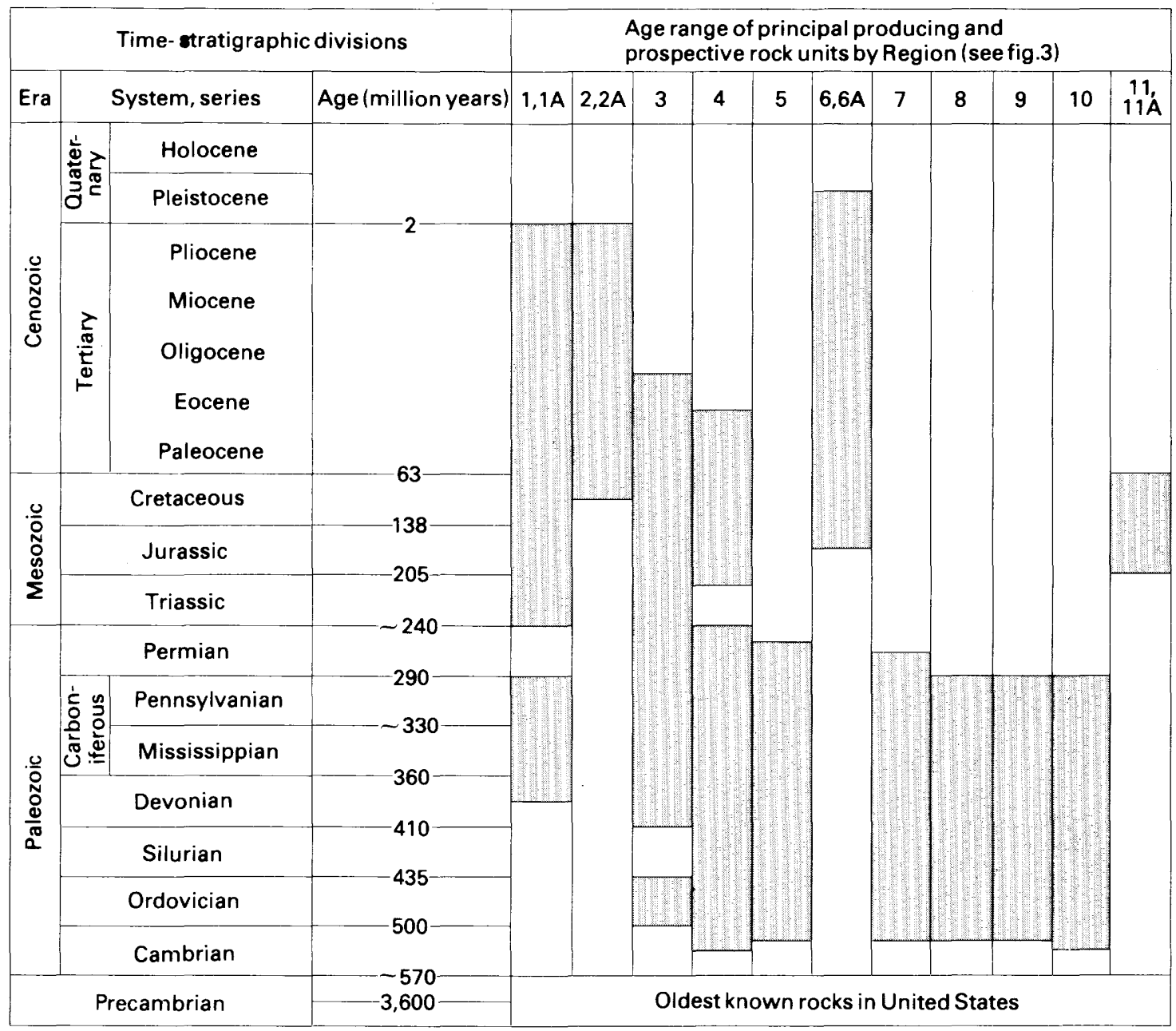

Figure 6.--Age range of principal producing and prospective reservoir rock units by petroleum Regions in the United States. 
Table 3.--Estimated areas and volumes of sedimentary rocks by Region

[Area is in thousands of square miles $\left(\mathrm{mi}^{2}\right)$ and square kilometers $\left(\mathrm{km}^{2}\right)$. Volume is in thousands of cubic $\mathrm{miles}\left(\mathrm{mi}{ }^{3}\right.$ ) and cubic kilometers $\left(\mathrm{km}^{3}\right)$. All tabulated values are rounded and may not be precisely additive due to rounding]

\begin{tabular}{|c|c|c|c|c|c|c|c|c|c|c|c|c|}
\hline & \multirow[b]{2}{*}{ Region } & \multicolumn{2}{|c|}{ Area } & \multicolumn{2}{|c|}{ Volume } & \multirow{2}{*}{\multicolumn{3}{|c|}{ Region }} & \multicolumn{2}{|c|}{ Area } & \multicolumn{2}{|c|}{ Volume } \\
\hline & & $\mathrm{mi}^{2}$ & $\mathrm{~km}^{2}$ & $\mathrm{mi}^{3}$ & $\mathrm{~km}^{3}$ & & & & $\mathrm{mi}^{2}$ & $\mathrm{~km}^{2}$ & $\mathrm{mi}^{3}$ & $\mathrm{~km}^{3}$ \\
\hline \multicolumn{6}{|c|}{ Onshore } & \multicolumn{7}{|c|}{ offshore } \\
\hline 1 & ...................... & 163 & 421 & 481 & 2,006 & $1 \mathrm{~A}$ & Alaska: & Shelf $\ldots . . . \ldots . .$. & 527 & 1,364 & 657 & 2,740 \\
\hline 2 & Pacific Coast..................... & 142 & 367 & 228 & 949 & & & s1ope............. & 170 & 441 & 277 & 1,154 \\
\hline 3 & Colorado Plateau-Basin and Range..... & 414 & 1,072 & 958 & 3,994 & $2 \mathrm{~A}$ & Pacific Coast: & She1f............. & 19 & 49 & 35 & 145 \\
\hline \multirow[t]{2}{*}{4} & Rocky Mountains-Northern & & & & & & & slope............ & 64 & 165 & 78 & 327 \\
\hline & Great Plains.................... & 415 & 1,074 & 591 & 2,463 & $6 \mathrm{~A}$ & Gulf of Mexico: & Shelf............. & 124 & 322 & 635 & 2,647 \\
\hline 5 & West Texas and Eastern New Mexico.... & 172 & 446 & 294 & 1,225 & & & slope............. & 95 & 246 & 485 & 2,022 \\
\hline 6 & Gulf Coast........................... & 237 & 614 & 783 & 3,263 & $11 \mathrm{~A}$ & Atlantic Coast: & Sheif $\ldots \ldots \ldots \ldots \ldots$ & 106 & 274 & 245 & 1,020 \\
\hline 7 & 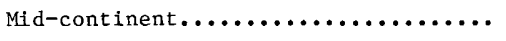 & 401 & 1,039 & 332 & 1,382 & & & slope.............. & 83 & 216 & 367 & 1,531 \\
\hline 8 & Michigan Basin $, \ldots, \ldots, \ldots, \ldots, \ldots, \ldots, \ldots$ & 122 & 316 & 109 & 455 & & & Total shelf....... & 776 & 2,010 & 1,572 & 6,552 \\
\hline 9 & Eastern Interior $\ldots \ldots \ldots \ldots \ldots \ldots \ldots \ldots$ & 193 & 501 & 240 & 1,001 & & & Total slope....... & 412 & 1,067 & 1,208 & 5,034 \\
\hline 10 & Appalachians......................... & 193 & 500 & 493 & 2,054 & & & & & & & \\
\hline \multirow[t]{3}{*}{11} & 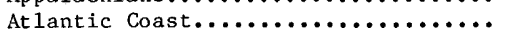 & 154 & 399 & 141 & 586 & & & Total offshore.... & 1,188 & 3,077 & 2,780 & 11,586 \\
\hline & Total onshore........................ & 2,606 & 6,749 & 4,649 & 19,377 & \multicolumn{7}{|c|}{ Onshore and offshore } \\
\hline & & & & & & Tota & a1 United Stat & .. & 3,794 & 9,826 & 7,429 & 30,963 \\
\hline
\end{tabular}

${ }^{1}$ Areas and volumes of sedimentary rocks in parts of interior Alaska were excluded because distribution of such rocks is too poorly known to estimate at this time. 
concerning the analogies between districts. Weeks (1950), Hendricks (1965), and Klemme (1980) discuss these procedures.

\section{Geochemical Material Balance Equations}

This is a special type of volumetric method in which estimates are made of the amounts of hydrocarbon generated, migrated, and trapped. This approach has been utilized mainly by Soviet geologists (for example, Neruchev, 1964).

\section{Play Analysis Methods}

In these methods the amount of hydrocarbon in a play or prospect is determined by use of a reservoir engineering equation, taking into account geologic risk factors. Often the input for each variable (such as thickness of reservoir rocks and porosity) of this equation is in the form of a probability distribution that is known or estimated. Monte Carlo methods commonly are used to generate a probability distribution for the amount of hydrocarbon. The study of the National Petroleum Reserve in Alaska by the U.S. Department of the Interior (1979) used a play analysis.

\section{Direct Subjective Assessment Methods}

In these methods, the quantity of resource is estimated directly on a subjective basis by an expert or team of experts. Geological information, and, generally, results of analyses by one or more of the other four methods, are reviewed and weighed. Delphi techniques commonly are employed. A direct subjective assessment method was used in the present report, as well as in Miller and others (1975).

\section{Appraisal Procedures for this Report}

In order to assess the total undiscovered recoverable crude oil and natural gas for the United States, the Nation was divided into geologic provinces, both onshore and offshore, and each province was individually assessed. The estimates of resources were based fundamentally upon analysis and review of available geological, geophysical, drilling and production data. The estimates represent direct judgements of the petroleum potential of each province made by a team of geologists using subjective probability techniques to address the problem of uncertainty.

\section{Data Compization}

Assembly of petroleum geology data was essential to the analysis and assessment. Available information concerning the petroleum geology, exploration status, and, where applicable, the petroleum history of each province was compiled by the province geologist on a standard form. The compilation was reviewed by a regional coordinator who gave particular attention to the determination of area, thickness, and volume of sedimentary rock; and to the selection of analog basins. After review, the regional coordinator added field and reservoir data, production and reserve statistics, and other supplementary information. A short form was prepared that summarized the compiled data for each province.

\section{Data Analysis}

A number of geological and statistical analyses were applied to the assessed provinces, dependent upon the type and availability of data. The main categories of analysis used were volumetric-yield analysis and finding-rate studies.

Volumetric-yield procedures were used to determine a range of hydrocarbon values useful as scaling factors. Yields from geologic analogs were used wherever possible. These analogs included internal analogs where known producibility was extrapolated into untested portions of a province, basin analogs using known yields of geologically similar basins, and structural or stratigraphic analogs using yields from structurally or stratigraphically similar basins. Potential yield categories as described by Klemme (1975) were applied selectively. Average, high, and low yields from the population of United States basins were also used as scaling factors without necessarily assuming geologic analogy.

Finding-rate studies provided an analytical tool when adequate drilling and discovery information was available (fig. 7). Findingrate studies were used to describe the relationship between discovered amounts of hydrocarbons and exploratory footage drilled. Curves fit to these historic data allow for extrapolation from which undiscovered resources may be determined, assuming a continuation of existing exploration trends and successes. Resource values determined by projection of exponential and hyperbolic decline curves are illustrated in figure 7 .

Structures were counted and measured in those few areas offshore where such data were available. These data, usually proprietary, were used for rough estimation of structural areas and closures, from which potential hydrocarbon volumes were calculated. Where available, detailed outer Continental Shelf (OCS) prospect analyses completed by the Conservation Division, USGS, were used.

\section{Resource estimation}

A resource appraisal team of 6-12. geologists met to make estimates of undiscovered resources for each of the provinces. The 
province geologist and the regional coordinator presented a summary of the geology and information pertinent to the evaluation. The data presented included an analysis and review of the province petroleum geology, exploration history, volumetric-yield procedures, findingrate studies, and structural analyses. Each member of the team then made an individual resource assessment for the province. Because of the uncertainty involved in appraising undiscovered resources, estimates of their quantities incorporated a range of values, and subjective probability procedures were used in their derivation.

Oil and non-associated gas were separately assessed for each province. The assessment of each resource involved probabilistic estimation of two uncertain events: (1) the presence of the assessed hydrocarbon, and (2) its quantity, if present.

As an example, in assessing undiscovered recoverable oil, an assessment must be made as to its presence within the province. Although the assumption of its presence may be made with confidence in producing provinces, this assumption cannot be made with certainty in areas where no economically recoverable petroleum has been discovered. In frontier areas where there has been little or no drilling, there is a risk that no recoverable petroleum exists. Therefore, the likelihood of any recoverable resource being present was estimated and was called the marginal probability. A marginal probability was estimated for the event "recoverable oil present" and for the event "recoverable nonassociated gas present." Associated-dissolved gas has the same marginal probability as does the oil with which it occurs.

Conditional upon recoverable resource being present, initial assessments were made for each of the assessed provinces as follows:

1. A low resource estimate corresponding to a 95-percent probability of more than that amount--this estimate is the 95th fractile $\left(\mathrm{F}_{95}\right)$.

2. A high resource estimate corresponding to a 5-percent probability of more than that amount--this estimate is the 5 th fractile $\left(\mathrm{F}_{5}\right)$.

3. A modal. ("most 1ikely") estimate of the quantity of resource associated with the greatest likelihood of occurrence.

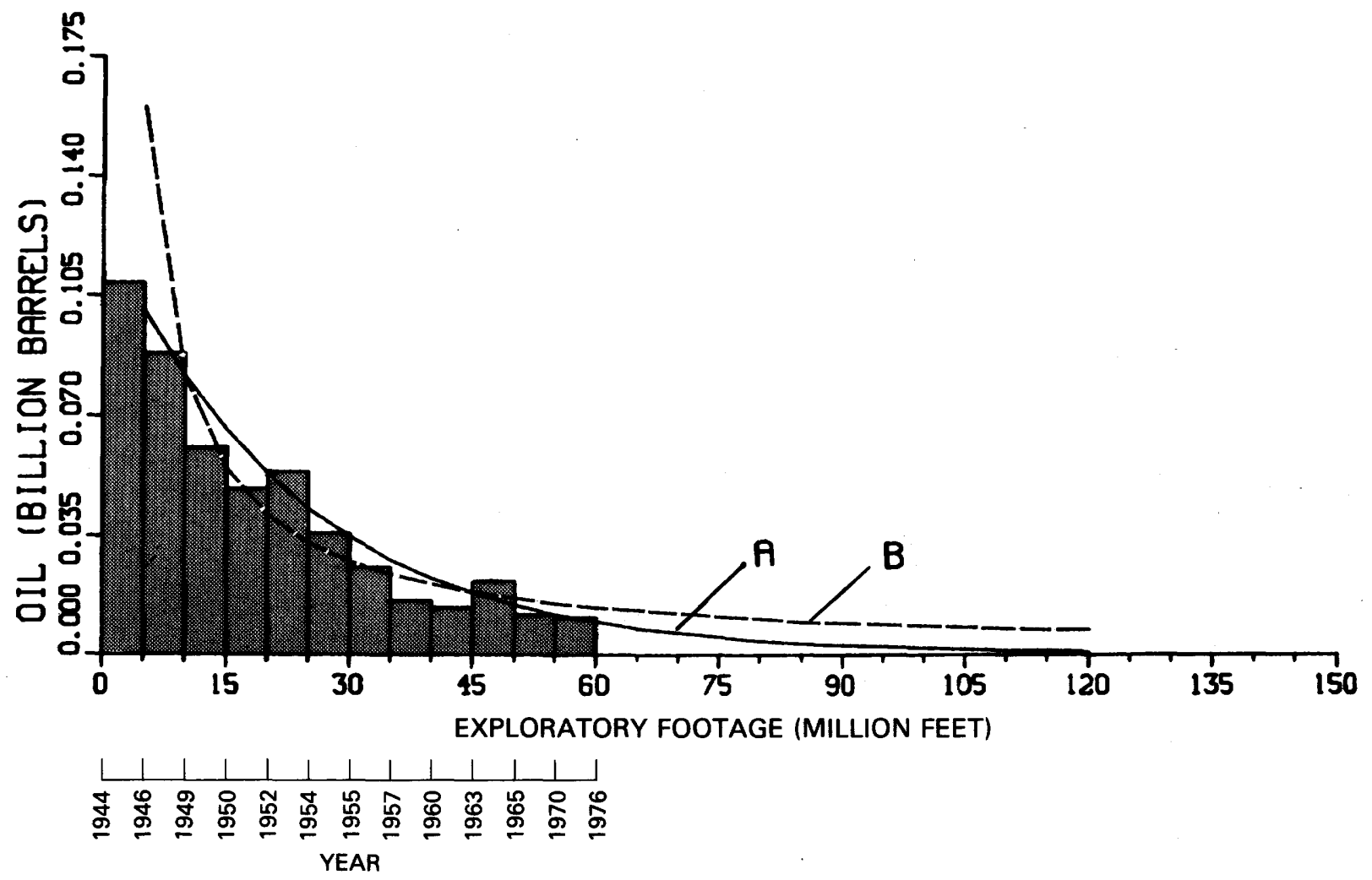

Figure 7.--Example of finding-rate curves showing extrapolation of exponential and hyperbolic curves. Historical data (data from Illinois basin) is from 1944 to 1976. The areas under the projected curves represent estimates of undiscovered recoverable oil to be found with the next 60 million feet of exploratory drilling. For the exponential curve $A$, the estimated amount of undiscovered recoverable oil is 0.038 billion barrels, and for the hyperbolic curve B, it is 0.115 billion barrels. 
Two, and in some cases three, separate iterations of the procedures were made, following the introduction of new or recast data. Each repetition included a subjective probability assessment by each assessor. The estimates from the final iteration consisted of four sets corresponding to the marginal probability and the low, high, and modal values. The estimates were averaged across assessors for each set, and the resulting average marginal probablity and 1ow, high, and modal values are the values that were processed using probabilistic methodology.

Non-associated gas and associated-dissolved gas were individually assessed. Non-associated gas was estimated directly by the subjective probability methods described. In contrast, the associated-dissolved gas was calculated through use of gas-oil ratios that had been separately determined for each province. The gas-oil ratio used represents a consensus estimate of the appraisal team and was based, when possible, on extrapolation of historic gas-oil ratios. The gas-oil ratio was applied to the estimated quantities of undiscovered oil in order to derive a corresponding distribution of quantities of undiscovered associated-dissolved gas.

\section{Methodology for Processing Probabilistic Assessments of Undiscovered Hydrocarbon Resources 1}

The procedures described for estimating the undiscovered recoverable resources for each province involved subjective probabilities. For each province the resource appraisal team expressed judgments as estimates of a marginal probability, two fractiles $\left(\mathrm{F}_{95}\right.$ and $\left.\mathrm{F}_{5}\right)$, and a modal value. These procedures were followed for al1 provinces, assuming independence among the provinces. The resources considered were oil, associated-dissolved gas, and non-associated gas. An assumption of independence was made between the two types of gas, whereas oil and associated-dissolved gas are completely dependent.

\section{Marginal Probability}

In the initial resource appraisal for a particular province, a condition was made that the resource was present in commercial quantities. Therefore, an estimate had to be made of the marginal probability--a subjective probability of the condition that the resource is actually present in recoverable quantities. These marginal probabilities were determined by the resource appraisal team as described in the previous section.

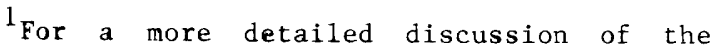
probabilistic methodology for oil and gas resource apraisal, see Crovelli (1981).
For an example, consider the North Atlantic Shelf province. At the present time there has been no commercial oil found in the province. The chance of oil being present in commercial quantities was estimated to be 42 percent, that is, a marginal probability of 0.42 .

\section{Conditional Probability Distribution}

The conditional low, high, and modal estimates of undiscovered recoverable resource described on p. 15 were used to determine a conditional probability distribution of the quantity of undiscovered recoverable resource for a province. The conditional probability distribution represents the judgmental probability distribution of the quantity of undiscovered recoverable resource conditioned on the recoverable resource being present. (This distribution is also referred to as the "unrisked" distribution.) A lognormal distribution was used as a probability model for the conditional probability distribution in a province. Because each pair of values among the three conditional estimates determines a lognormal distribution, there are three possible lognormal distributions. The fitted lognormal distribution with the largest standard deviation was chosen.

A conditional probability distribution can be described in several ways. One standard approach, which was used in this study, is the conditional "more-than" cumulative distribution function (fig. $8 \mathrm{~A}$ ) that gives the probability of more than a specific amount. From this function, all the fractiles can be obtained easily. Another approach is the conditional probability density function ( $\mathrm{fig} .8 \mathrm{~B}$ ) in which an area under its curve represents probability. The shape of the curve of this function helps to visualize where the probability is located.

The conditional probability distribution of the undiscovered recoverable oil for the North Atlantic Shelf province is used for illustrative purposes in figure 9. The curve of the conditional more-than cumulative distribution function is shown in figure $9 \mathrm{~A}$; the curve of the probability density function is given in figure $9 B$. Some numerical characteristics (in billion barrels) of the lognormal distribution in figure 9 are the following: 95th fractile $\mathrm{F}_{95}=0.18$, 5th fractile $\mathrm{F}_{5}=3.14$, mean $\mu=1.08$, and standard deviation $\sigma=1.19$.

\section{Probabizity Distribution}

The marginal probability of a resource for a province was applied to its corresponding conditional probability distribution to produce the judgmental probability distribution of the quantity of undiscovered recoverable resource. (This distribution also is referred to as the "unconditional" or "risked" distribution.) From the probability distribution, the final low 

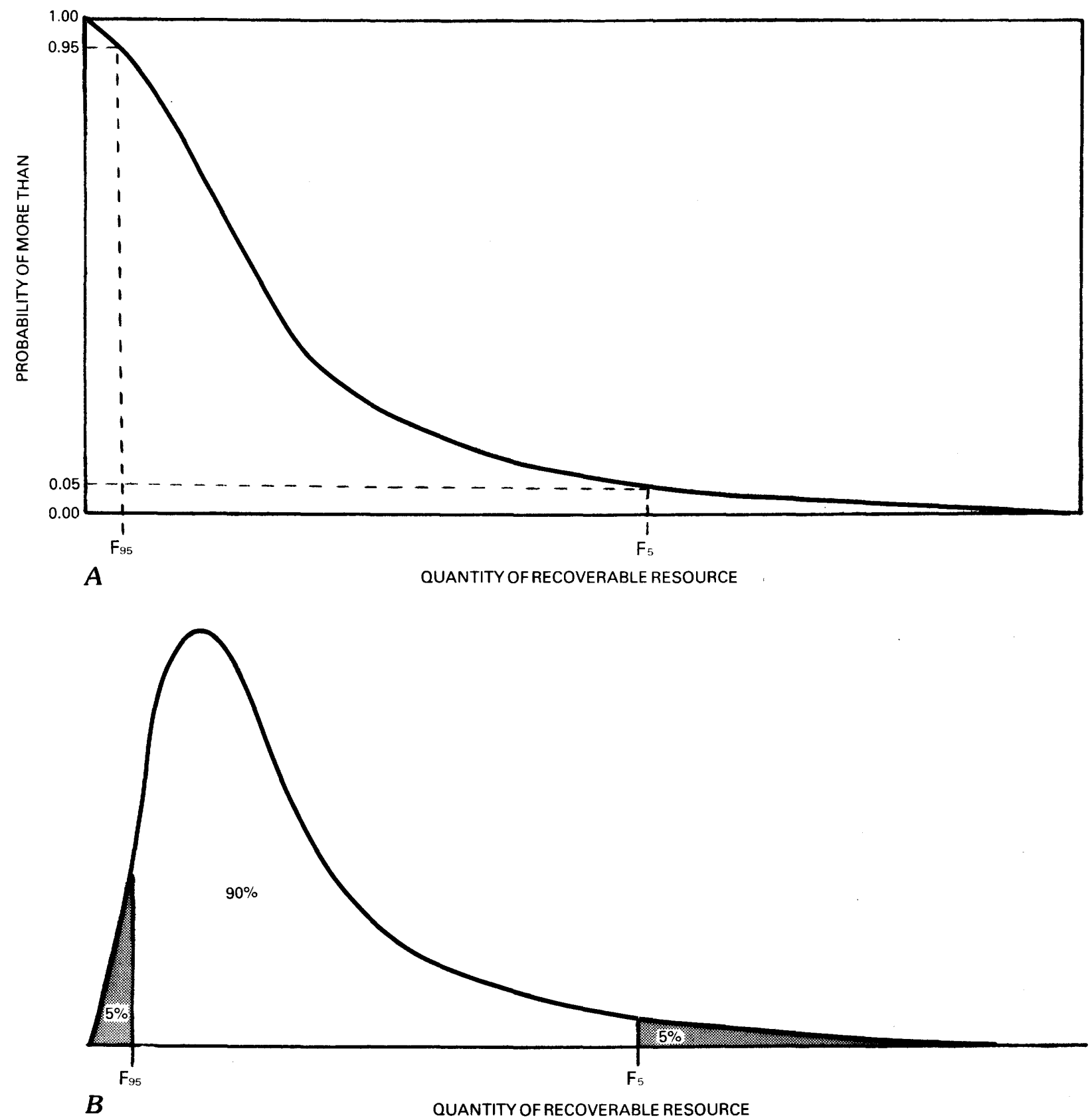

Figure 8.--Typical conditional probability distribution of an undiscovered recoverable resource shown as $A$, conditional more-than cumulative distribution function, and $B$, conditional probability density function. $F_{95}$ denotes the 95 th fractile; the probability of more than the amount is 95 percent. $F_{5}$ denotes the 5 th fractile; the probability of more than the amount is 5 percent. 

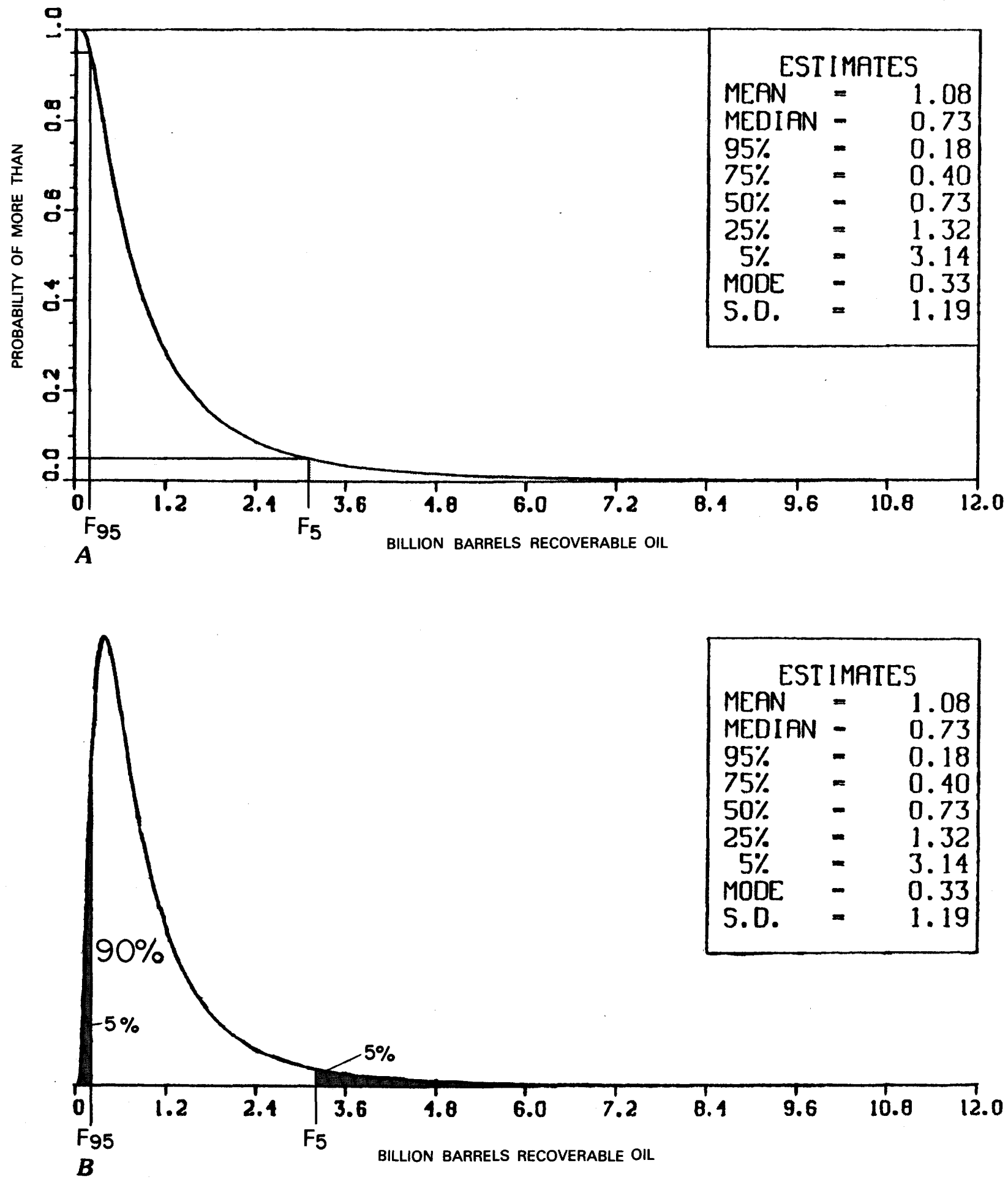

Figure 9.--Conditional probability distribution of the undiscovered recoverable oil for the North Atlantic Shelf province expressed as $A$, conditional more-than cumulative distribution function, and $B$, conditional probability density function. Estimates are mean, median, mode, standard deviation (S.D.), and fractiles that correspond to the percentages listed. 

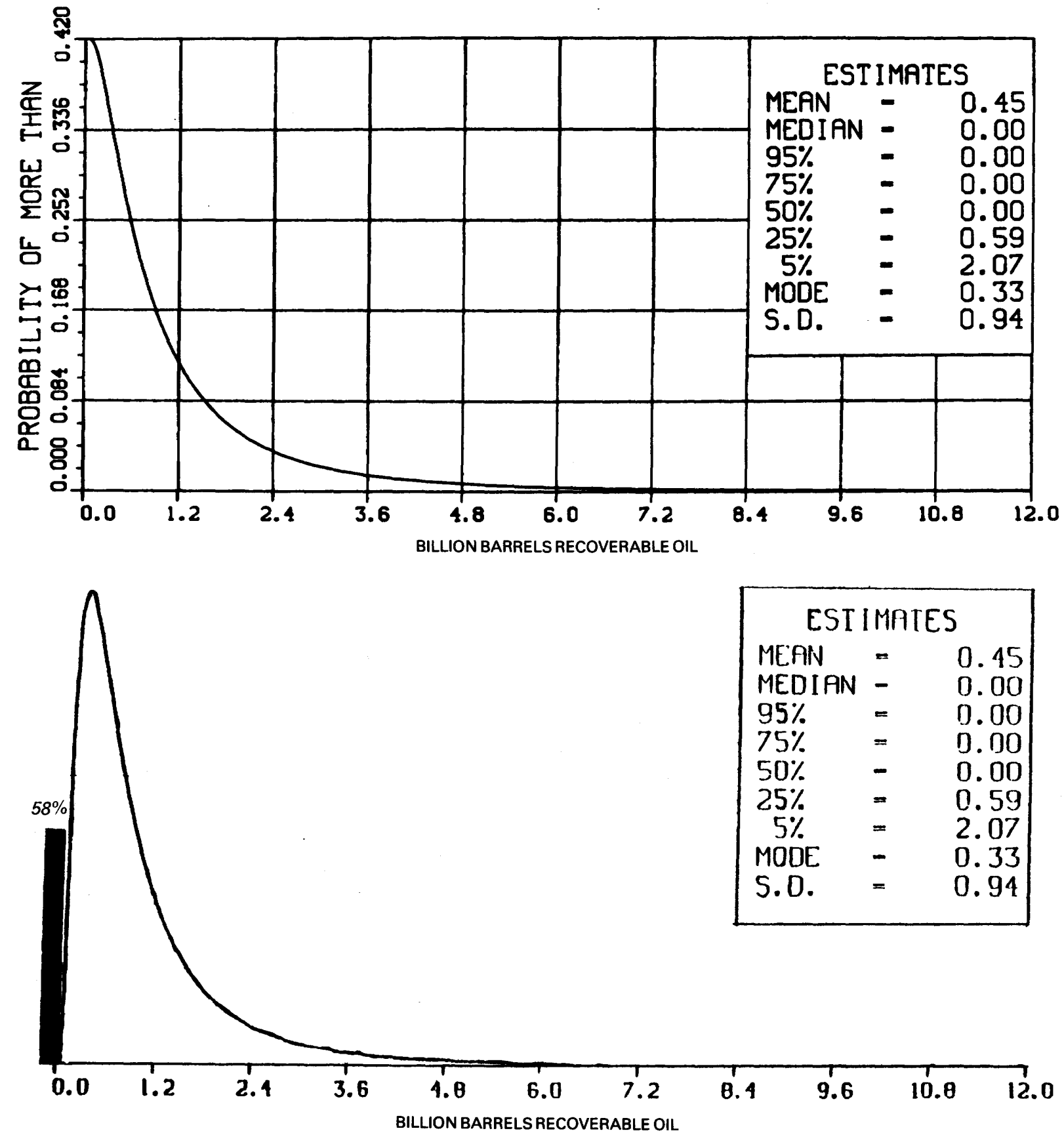

Figure 10.--Probability distribution of the undiscovered recoverable oil for the North Atlantic Shelf province expressed as $A$, more-than cumulative distribution function, and $B$, probability density function. $A$ has the value of the marginal probability (0.42) at zero resource. $B$ has a spike at zero resource of probability weight $1-0.42=0.58$ which represents the chance of no recoverable oil being present. Estimates are mean, median, mode, standard deviation (S.D.), and fractiles that correspond to percentages listed. 
$\left(\mathrm{F}_{95}\right)$, high $\left(\mathrm{F}_{5}\right)$, and mean $(\mu)$ estimates of the quantity of undiscovered recoverable resource were obtained for the province. The mean estimate is the mean of the probability distribution.

Referring once again to the North Atlantic Shelf province, the probability distribution of the undiscovered recoverable oil is given in figure 10. Some numerical characteristics (in billion barrels) of this distribution are the following: 95th fractile $F_{95}=0$, 5th fractile $\mathrm{F}_{5}=2.07$, mean $\mu 0.45$, and standard deviation $\sigma=0.94$. Note that the curve of the morethan cumulative distribution function (fig. 10 $A)$ has the value of the marginal probability $(0.42)$ at zero. The probability density function (fig. $10 \mathrm{~B}$ ) has a spike at zero of probability weight $1-0.42=0.58$ which represents the chance of no oil being present in commercial quantities; this function helps to visualize where the probability is located.

\section{Aggregate Probability Distribution}

An aggregate probability distribution is the judgmental probability distribution of the total quantity of undiscovered recoverable resource in an area consisting of two or more provinces. Hence, an aggregate probability distribution is the convolution of two or more probability distributions; so that we have the distribution of the sum of two or more independent random variables. In which case, the mean value for an area equals the sum of the mean values for the provinces making up the area. Similarly, the variance (square of the standard deviation) for an area equals the sum of the variances. The aggregate marginal probability is the subjective probability of the resource being present in commercial quantities within the area (one or more provinces) considered.

A Monte Carlo technique was used to aggregate the probability distributions of the provinces of an area to derive its aggregate probability distribution. From this distribution, the low $\left(\mathrm{F}_{95}\right)$, high $\left(\mathrm{F}_{5}\right)$, and mean $(\mu)$ estimates of the quantity of undiscovered recoverable resource were obtained for the area. An aggregate probability distribution of each resource was determined for each of several areas of the United States. Areas whose provinces were aggregated included the 15 Regions, the onshore area, the offshore area, and the entire United States. Each area considered has four corresponding aggregations: oil, associated-dissolved gas, nonassociated gas, and total gas.

For an illustrative example of an aggregation, a second province will be introduced and aggregated with the North Atlantic Shelf province discussed earlier. The probability distribution of the undiscovered recoverable oil for the Mid-Atlantic Shelf province is given in figure 11. Some numerical characteristics (in billion barrels) of this distribution are the following: 95th fractile $F_{95}=0$, 5th fractile $\mathrm{F}_{5}=2.63$, mean $\mu=0.78$, and standard deviation $\sigma=1.03$. Note that the marginal probability is equal to 69 percent.

Let the combined North Atlantic and MidAtlantic Shelf area consist of the two provinces: North Atlantic Shelf (fig. 10) and Mid-Atlantic Shelf (fig. 11). The aggregate probability distribution represents the judgmental probability distribution of the total quantity of undiscovered recoverable oil for the combined area and is given in figure 12. Some numerical characteristics (in billion barrels) of this distribution are the following: 95th fractile $\mathrm{F}_{95}=0$, $5 \mathrm{th}$ fractile $\mathrm{F}_{5}=3.76$, mean $\mu=1.23$, and standard deviation $\sigma=1.39$. There are important relationships between the provinces and the area as follows:

Aggregate marginal probability:

$$
1-(1-0.42)(1-0.69)=0.82
$$

Aggregate mean:

$$
0.45+0.78=1.23
$$

Aggregate standard deviation:

$$
\sqrt{(0.94)^{2}+(1.03)^{2}}=1.39
$$

\section{Summary of Methodology}

Individual appraisals were made for each of the provinces using province petroleum geology, volumetric-yield procedures, exploration histories, and, in some provinces, finding-rate studies and structural analyses as a basis for subjective assessments of oil and gas. A lognormal distribution was fitted using low, high, and modal estimates to determine the conditional probability distribution for each province. By applying the marginal probability to the conditional probability distribution, the probability distribution of the quantity of undiscovered resource was established. To obtain total resource estimates for an area, the probability distributions for the provinces composing the area were aggregated by a Monte Carlo technique. From aggregate probability distributions, final estimates were obtained for areas including the 15 Regions, the onshore area, the offshore area, and the entire United States.

\section{CALCULATION OF RESOURCES OF NATURAL GAS LIQUIDS}

Natural gas liquids (NGL) are produced with both associated-dissolved and non-associated gas. The cumulative production of the two gas types and their corresponding NGL have been published by the AGA (API and others, 19671980). From these statistics, historical production ratios of NGL to natural gas (barrels 


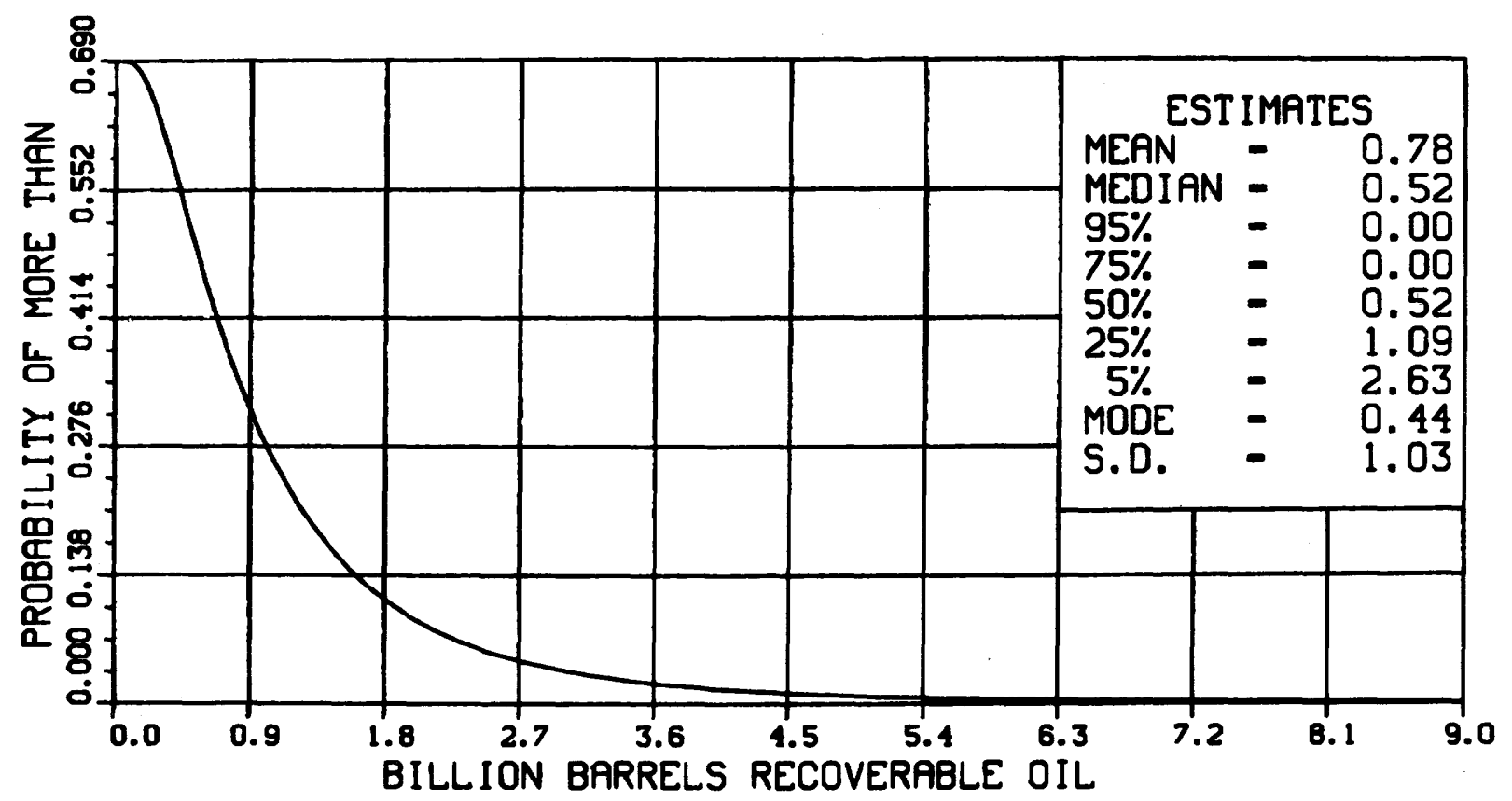

Figure 11.--Probability distribution of the undiscovered recoverable oil for the Mid-Atlantic Shelf province. Estimates are mean, median, mode, standard deviation (S.D.), and fractiles that correspond to the percentages listed.

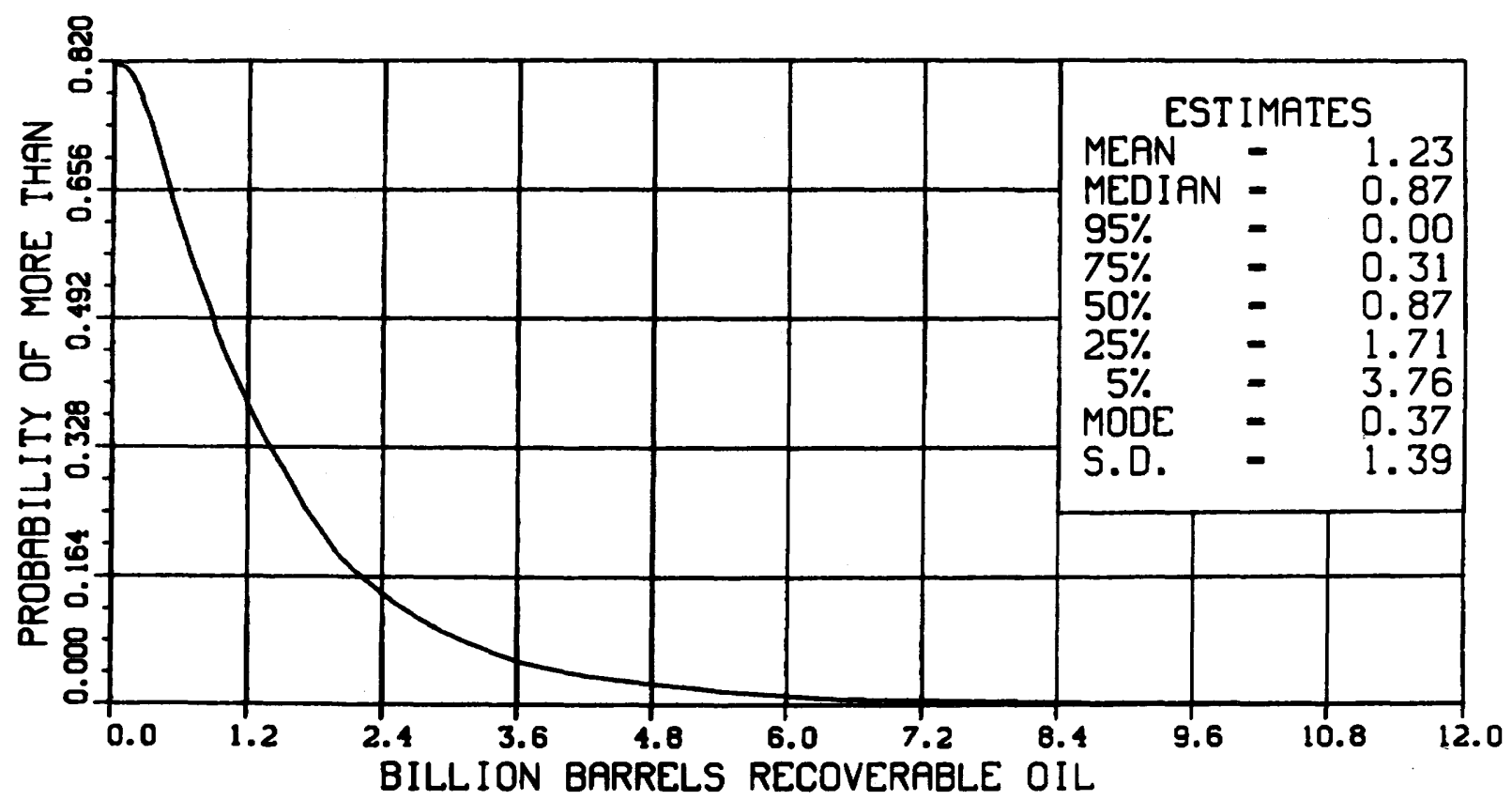

Figure 12.--Aggregate probability distribution of the undiscovered recoverable oil for the combined North Atlantic and Mid-Atlantic Shelf area. Estimates are mean, median, mode, standard deviation (S.D.), and fractiles that correspond to the percentages 1 isted. 
Table 4.--Crude oil--Production, reserves, and estimates of undiscovered recoverable resources of the United States

[All tabulated values are rounded numbers; therefore, values for production and reserves and for means of undiscovered resources, all of which are additive, may not be precisely so. Values shown are in billions of barrels. Negl., negligible, less than or equal to 0.05 billion barrels of oil]

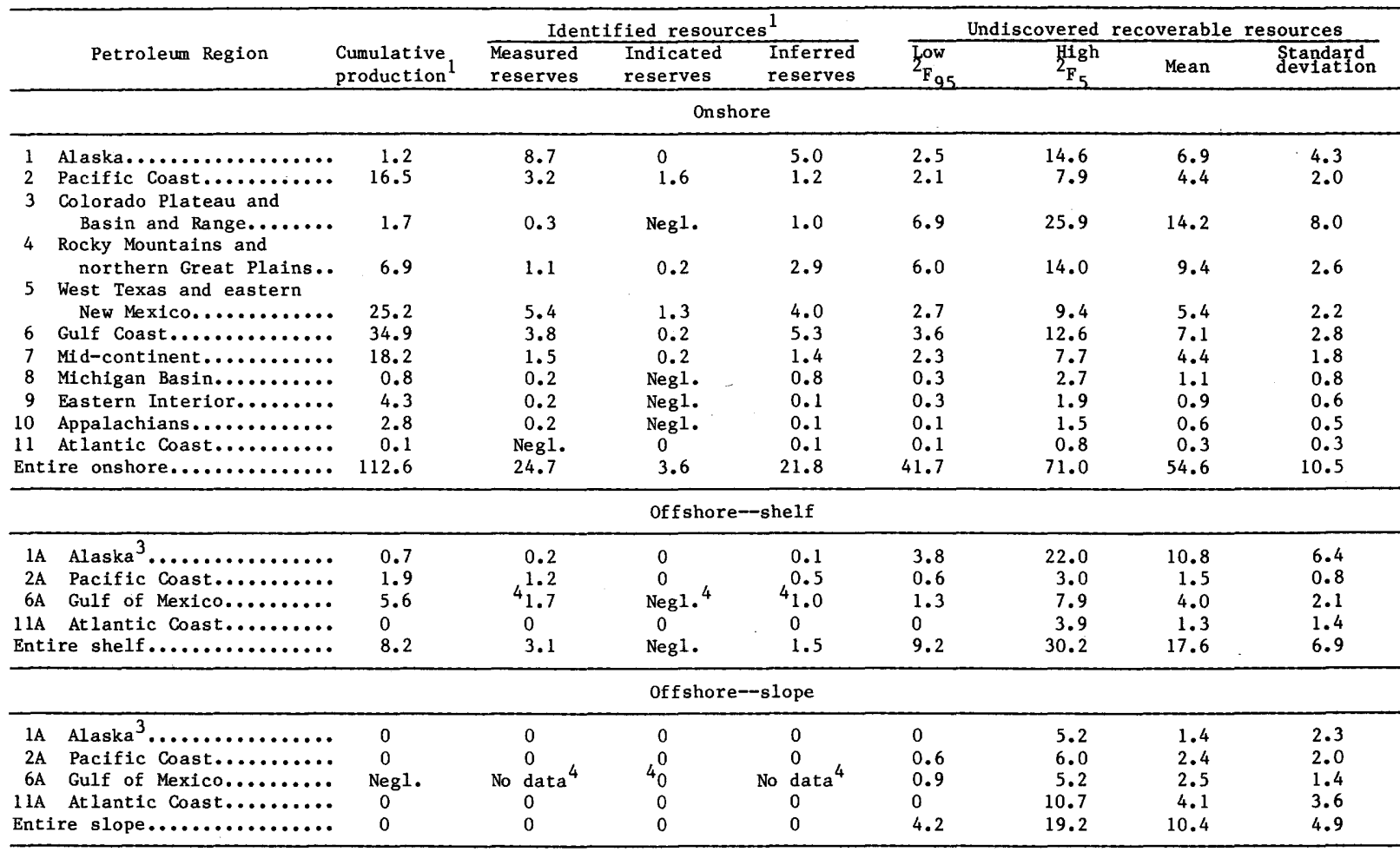

\begin{tabular}{|c|c|c|c|c|c|c|c|c|c|}
\hline \multicolumn{10}{|c|}{ offshore--combined shelf and slope } \\
\hline $1 \mathrm{~A}$ & Alaska ${ }^{3} \ldots \ldots \ldots \ldots \ldots$ & 0.7 & 0.2 & 0 & 0.1 & 4.6 & 24.2 & 12.2 & 6.8 \\
\hline $2 \mathrm{~A}$ & Pacific Coast.......... & 1.9 & 1.2 & 0 & 0.5 & 1.7 & 7.9 & 3.8 & 2.2 \\
\hline $6 \mathrm{~A}$ & Gulf of Mexico.......... & 5.6 & 1.7 & Neg1. & 1.0 & 3.1 & 11.1 & 6.5 & 2.5 \\
\hline $11 \mathrm{~A}$ & At lantic Coast.......... & 0 & 0 & 0 & 0 & 1.1 & 12.9 & 5.4 & 3.9 \\
\hline Entir & re offshore............ & 8.2 & 3.1 & Neg1. & 1.5 & 16.9 & 43.5 & 28.0 & 8.5 \\
\hline
\end{tabular}

Combined onshore and of $f$ shore

\begin{tabular}{llllllll}
\hline Entire United States........ & 120.7 & 27.8 & 3.6 & 23.4 & 64.3 & 105.1 & 82.6 \\
\hline
\end{tabular}

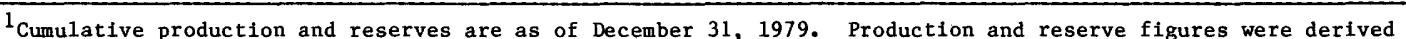
from API and AGA data (American Petroleum Institute, American Gas Association, and Canadian Petroleum Association, 1980) except for California for which production and reserve data were taken from California Division of Oil and Gas (1980) and the U.S. Geological Survey (Ka1il, 1980).

${ }^{2} \mathrm{~F}_{95}$ denotes the $95 \mathrm{th}$ fractile; the probability of more than the amount $\mathrm{F}_{95}$ is 95 percent. $\mathrm{F}_{5}$ is defined similarly. Fractile values are not additive.

${ }^{3}$ Includes quantities considered recoverable only if technology permits their exploitation beneath Arctic pack ice--a condition not yet met.

${ }^{4} \mathrm{API}$ and AGA reserve data for the Gulf of Mexico are not available within separate shelf and slope classifications. However, the declared reserves probably represent only the shelf and are so treated.

NGL/million cubic feet gas) were calculated for each of the two gas types for various areas of the country. The estimates of undiscovered recoverable NGL were obtained by multiplying these ratios by the corresponding mean estimates of undiscovered recoverable natural gas of each type. Where historical data were not available, or where future development might substantially alter the current ratio, the national average ratios were used; these are 52.21:1 for associated-dissolved gas and 25.23:1 for nonassociated gas.

\section{CALCULATION OF INFERRED RESERVES}

Estimates of the amounts of oil and gas credited to the year of discovery by the API and others (1967-1980) tend to increase through time 
Table 5.--Associated-dissolved gas--Production, reserves, and estimates of undiscovered recoverable resources of the United States

[All tabulated values are rounded numbers; therefore, values for production and reserves and for means of undiscovered resources, all of which are additive, may not be precisely so. Values shown are in trillion cubic feet. Negl., negligible, less than or equal to 0.05 trillion cubic feet of gas]

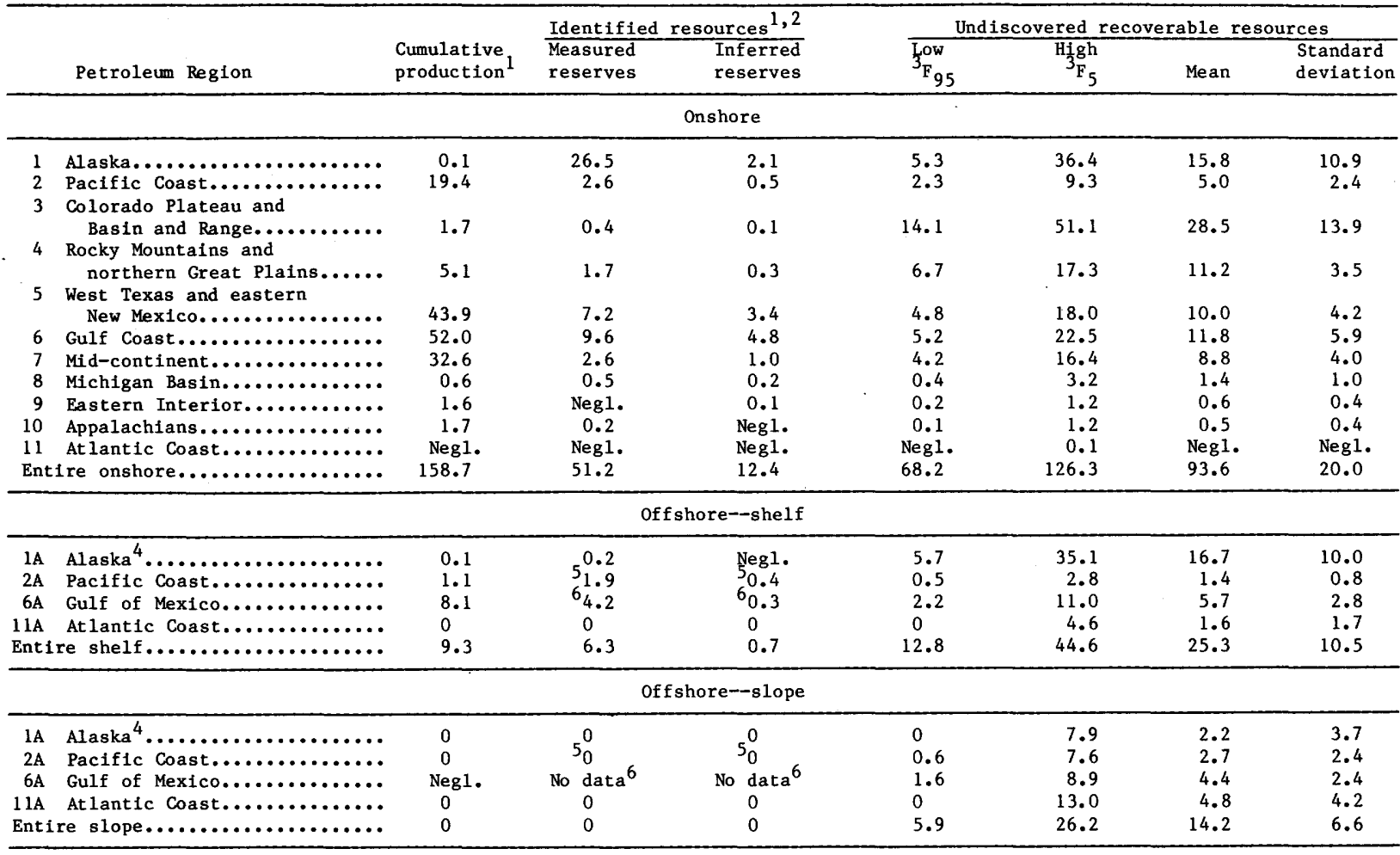

offshore--combined shelf and slope

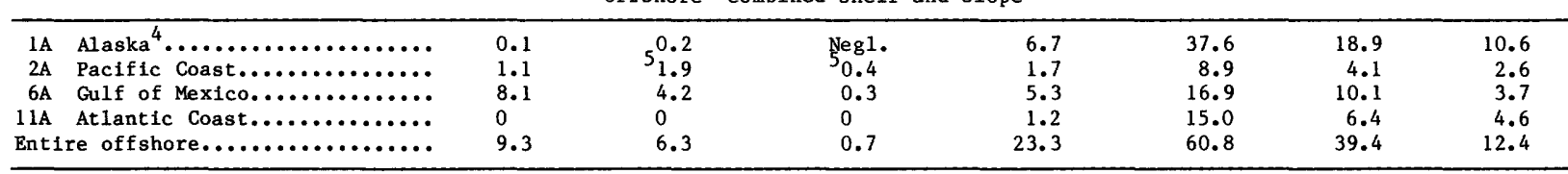

Combined onshore and offshore

\begin{tabular}{llllll}
\hline Entire United States............ 167.9 & 57.5 & 13.1 & 101.0 & 133.0 & 23.5
\end{tabular}

${ }^{1}$ Cumulative production and reserves are as of December 31 , 1979. Production and reserve figures were derived from API and AGA data (American Petroleum Institute, American Gas Association, and Canadian Petroleum Association, 1980) except for California for which production and reserve data were taken from California Division of Oil and Gas (1980) and the U.S. Geological Survey (Kalil, 1980).

2 Does not include gas in storage.

$3_{F_{95}}$ denotes the 95 th fractile; the probability of more than the amount $F_{95}$ is 95 percent. $F_{5}$ is defined similarly. Fractile values are not additive.

${ }^{4}$ Includes quantities considered recoverable only if technology permits their exploitation beneath Arctic pack ice-a condition not yet met.

${ }^{5}$ Estimates of non-associated and associated-dissolved gas reserves in California Federal offshore areas are not recorded separately. All gas in these areas is treated here as associated-dissolved.

${ }^{6} \mathrm{API}$ and AGA reserve data for the Gulf of Mexico are not available within separate shelf and slope classifications. However, the declared reserves probably represent only the shelf and are so treated.

as a consequence of revisions, extensions, and additions of new reservoirs to old fields. That part of the economic resources that will be added as a result of this growth in the future is inferred reserves.

Estimates of ultimate production from known fields, including growth, as of the end of 1978 were calculated by D. H. Root (Appendix F). We 
[All tabulated values are rounded numbers; therefore, values for production and reserves and for means of undiscovered resources, all of which are additive, may not be precisely so. Values shown are in trillion cubic feet. Negl., negligible, less than or equal to 0.05 trillion cubic feet of gas]

\begin{tabular}{|c|c|c|c|c|c|c|c|}
\hline \multirow[b]{2}{*}{ Petroleum Region } & \multirow[b]{2}{*}{$\begin{array}{l}\text { Cumulative } \\
\text { praduction }\end{array}$} & \multicolumn{2}{|c|}{ Identified resources 1,2} & \multicolumn{4}{|c|}{ Und iscovered recoverable resources } \\
\hline & & $\begin{array}{l}\text { Yeasured } \\
\text { reserves }\end{array}$ & $\begin{array}{l}\text { Inferred } \\
\text { reserves }\end{array}$ & $\begin{array}{l}\text { Low } \\
3_{95}\end{array}$ & $\begin{array}{l}\text { High } \\
3_{5}\end{array}$ & Mean & $\begin{array}{l}\text { Standard } \\
\text { deviation }\end{array}$ \\
\hline \multicolumn{8}{|c|}{ Onshore } \\
\hline 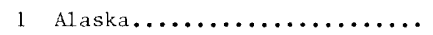 & 1.1 & 3.5 & 2.3 & 10.0 & 37.0 & 20.7 & 8.9 \\
\hline 2 Pacific Coast.............. & 7.6 & 1.7 & 3.3 & 4.4 & 19.5 & 9.6 & 4.9 \\
\hline 3 Colorado plateau and & & & & & & & \\
\hline Basin and Range.......... & 13.3 & 11.0 & 4.4 & 30.2 & 111.1 & 61.6 & 26.3 \\
\hline 4 Rocky Mountains and & & & & & & & \\
\hline $\begin{array}{l}\text { northern Great Plains...... } \\
5 \text { West Texas and eastern }\end{array}$ & 8.1 & 5.4 & 5.2 & 19.8 & 56.2 & 34.5 & 12.1 \\
\hline New Mexico....................... & 26.8 & 8.8 & 14.7 & 13.9 & 67.3 & 32.8 & 17.3 \\
\hline 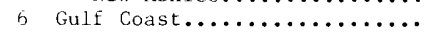 & 176.4 & 35.7 & 69.5 & 45.7 & 228.3 & 112.6 & 63.3 \\
\hline 7 Mid-continent............. & 95.2 & 29.4 & 17.9 & 15.8 & 68.9 & 35.7 & 18.0 \\
\hline 8 Michigan Basin............ & 0.7 & 0.6 & 0.8 & 0.9 & 9.3 & 3.8 & 3.0 \\
\hline 9 Eastern Interior........... & 0.2 & Negl. & Negl. & 0.8 & 4.4 & 2.1 & 1.2 \\
\hline 10 Appalachians............. & 32.5 & 6.0 & 5.8 & 6.0 & 43.9 & 19.7 & 13.2 \\
\hline 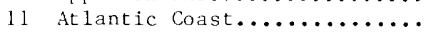 & 0 & 0 & 0 & 0 & 0.3 & 0.1 & 0.3 \\
\hline 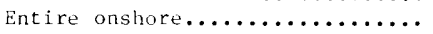 & 361.9 & 1102.0 & 124.1 & 235.6 & 468.4 & 333.2 & 75.9 \\
\hline \multicolumn{8}{|c|}{ Of Eshore--shelf } \\
\hline IA Alaska ${ }^{4} \ldots \ldots \ldots \ldots \ldots \ldots$ & 0.5 & 1.7 & 1.1 & 16.0 & 78.4 & 40.7 & 21.4 \\
\hline 2 A Pacific Coast $\ldots \ldots \ldots \ldots \ldots$ & 0.4 & Negl. 5 & Negl. 5 & 0.2 & 3.5 & 1.2 & 1.2 \\
\hline 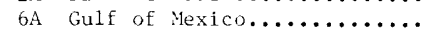 & 47.2 & 630.2 & 639.1 & 17.4 & 74.1 & 39.5 & 18.3 \\
\hline 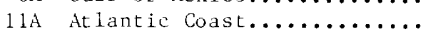 & 0 & 0 & 0 & 1.1 & 15.6 & 6.7 & 4.8 \\
\hline 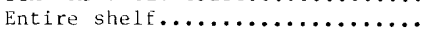 & 48.2 & 31.9 & 40.3 & 50.6 & 139.1 & 88.2 & 28.6 \\
\hline \multicolumn{8}{|c|}{ Offshore--slope } \\
\hline $1 \mathrm{~A} \mathrm{Alaska}^{4} \ldots \ldots \ldots \ldots \ldots \ldots \ldots$ & 1) & 0 & 0 & () & 15.2 & 5.11 & 11.7 \\
\hline $2 A$ Pacific Coast........... & 1) & 50 & 50 & 0.8 & 4.9 & 1.6 & 1.7 \\
\hline 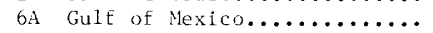 & 0 & No data 6 & No data 6 & 7.6 & 47.7 & 22.2 & 13.6 \\
\hline 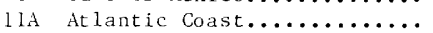 & 1) & 0 & 0 & 10 & 27.0 & 111.0 & 8.6 \\
\hline Entire slope................. & 0 & 0 & 0 & 17.2 & 71.6 & 39.4 & 20.11 \\
\hline
\end{tabular}

Offshore--combined shelf and slope

\begin{tabular}{|c|c|c|c|c|c|c|c|c|}
\hline $1 \mathrm{~A}$ & $\mathrm{Alaska}^{4} \ldots \ldots \ldots \ldots \ldots \ldots$ & 0.5 & 1.7 & 1.1 & 19.1 & 89.1 & 45.7 & 24.4 \\
\hline $2 \mathrm{~A}$ & Pacific Coast........... & 0.4 & $\operatorname{Neg} 1.5$ & $\operatorname{Neg} 1 .^{5}$ & 1.2 & 7.11 & 2.8 & 2.1 \\
\hline $6 \mathrm{~A}$ & Gulf of Hexico........... & 47.2 & 30.2 & 39.1 & 32.5 & 103.4 & 61.8 & 22.8 \\
\hline $11 \mathrm{~A}$ & Atlantic Coast............ & 0 & 0 & 0 & 6.5 & 36.4 & 17.3 & 9.8 \\
\hline \multicolumn{2}{|r|}{ Entire oftshore............. } & 48.2 & 31.9 & 40.3 & 80.3 & 188.8 & 127.6 & 34.8 \\
\hline
\end{tabular}

Combined onshore and offshore

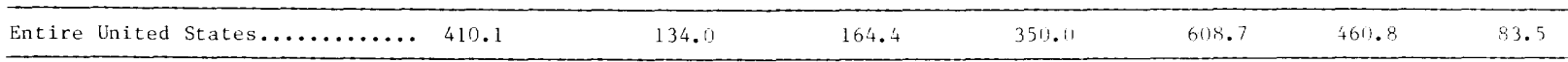

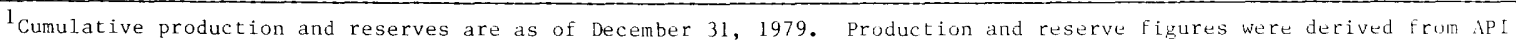
and AGA data (American Petroleum Institute, American Gas Association, and Canadian Petroleum issociation, 1980 ) ezcept for California for which production and reserve data were taken from the California Division of (Iil and Gas (1980) and the U.S. Geological Survey (Kali1, 1980).

2 Does not include gas in storage.

${ }^{3} \mathrm{~F}_{95}$ denotes the 95 th fractile; the probability of more than the amount F95 is 95 percent. E 5 is defined similarly. Fractile values are not additive.

${ }^{4}$ Includes quantities considered recoverable only if technology permits their exploitation beneath arctic pack ice--a condition not yet met.

${ }^{5}$ Estimates of non-associated and associated-dissolved gas reserves in Califurnia Federal offshore areas are not recorded separately. All gas in these areas is here treated as associated-dissolved yas.

${ }^{6} \mathrm{API}$ and AGA reserve data for the Gulf of Yexico are not available within separate shele and slope classifications. However, the declared reserves probably represent only the shelf and are so treated.

adjusted these estimates for discoveries made in 1979. API cumulative production, proved reserves, and indicated additional reserves as of the end of 1979 were subtracted from these adjusted estimates to obtain our inferred reserves. The inferred reserves were allocated 
Table 7.--Total gas--Production, reserves, and estimates of undiscovered recoverable resources of the United States

[All tabulated values are rounded numbers; therefore values for production and reserves and for means of undiscovered resources, all of which are additive, may not be precisely so. Values shown are in trillion cubic feet. Neg1., negligible, less than or equal to 0.05 trillion cubic feet of gas]

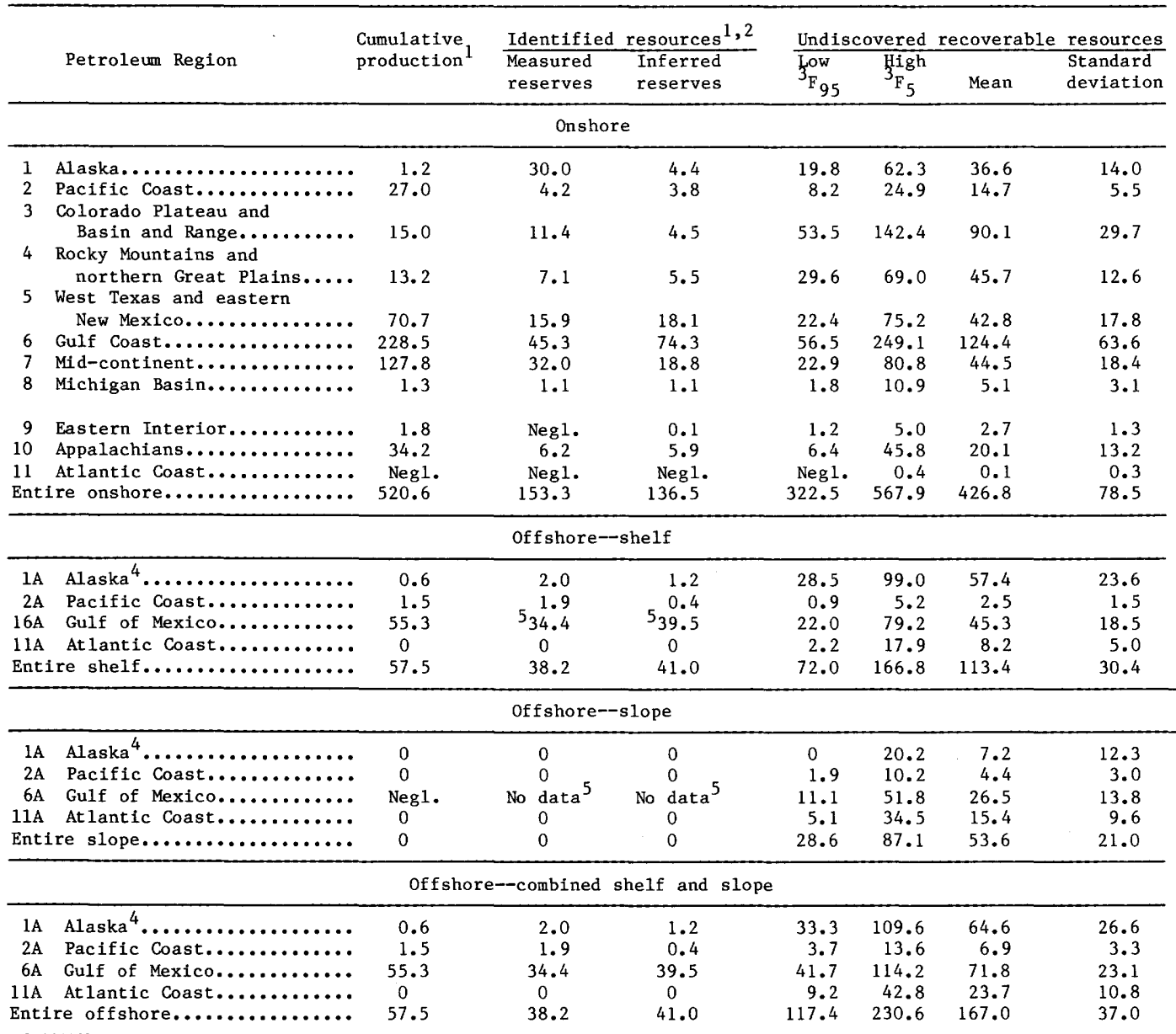

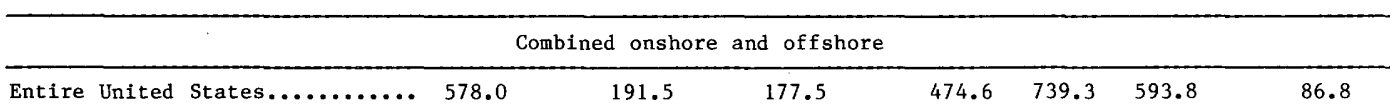

${ }^{1}$ Cumulative production and reserves are as of December $31,1979$. Production and reserve figures were derived from API and AGA data (American Petroleum Institute, American Gas Association, and Canadian Petroleum Association, 1980) except for California for which production and reserve data were taken from California Division of $0 i 1$ and Gas (1980) and the U.S. Geological Survey (Kalil, 1980).

2 Does not include gas in storage.

$3_{F_{95}}$ denotes the 95 th fractile; the probability of more than the amount $F_{95}$ is 95 percent. $\mathrm{F}_{5}$ is defined similarly. Fractile values are not additive.

${ }^{4}$ Includes quantities considered recoverable only if technology permits their exploitation beneath Arctic pack ice--a condition not yet met.

${ }^{5}$ API and AGA reserve data for the Gulf of Mexico are not available within separate shelf and slope classifications. However, the declared reserves probably represent only the shelf and are so treated.

to our Regions.

Inasmuch as oil and gas data do not allow the development of separate growth histories for
Al aska, the conterminous Alaska. pattern of growth shown for the States as a whole was used for 
ESTIMATES OF PETROLEUM RESOURCES

Results of Study

Tabulations of cumulative production; measured, indicated and inferred reserves; and estimates of undiscovered recoverable hydrocarbon resources are presented in tables 4 through 7. Statistics for oil (table 4), associated-dissolved gas (table 5), nonassociated gas (table 6), and total natural gas (table 7) are presented for each of the 15 Regions as we 11 as for the onshore area, the offshore area, the entire United States, and other selected areas. Individual province estimates of undiscovered resources are provided in Appendixes $C$ and $D$.

The data for cumulative production, measured reserves, and indicated reserves in tables 4 through 7 were derived from the API and AGA (API and others, 1980) except that California reserve statistics were based on data from the California Division of $0 i 1$ and Gas (1979) and the U.S. Geological Survey (Kalil, 1980). In some instances, reserves had to be allocated between two or more Regions; where done, all divisions were made proportional to the 1978 annual production. Inferred reserves were calculated from these data by the procedures discussed on p. 22 . These reserves

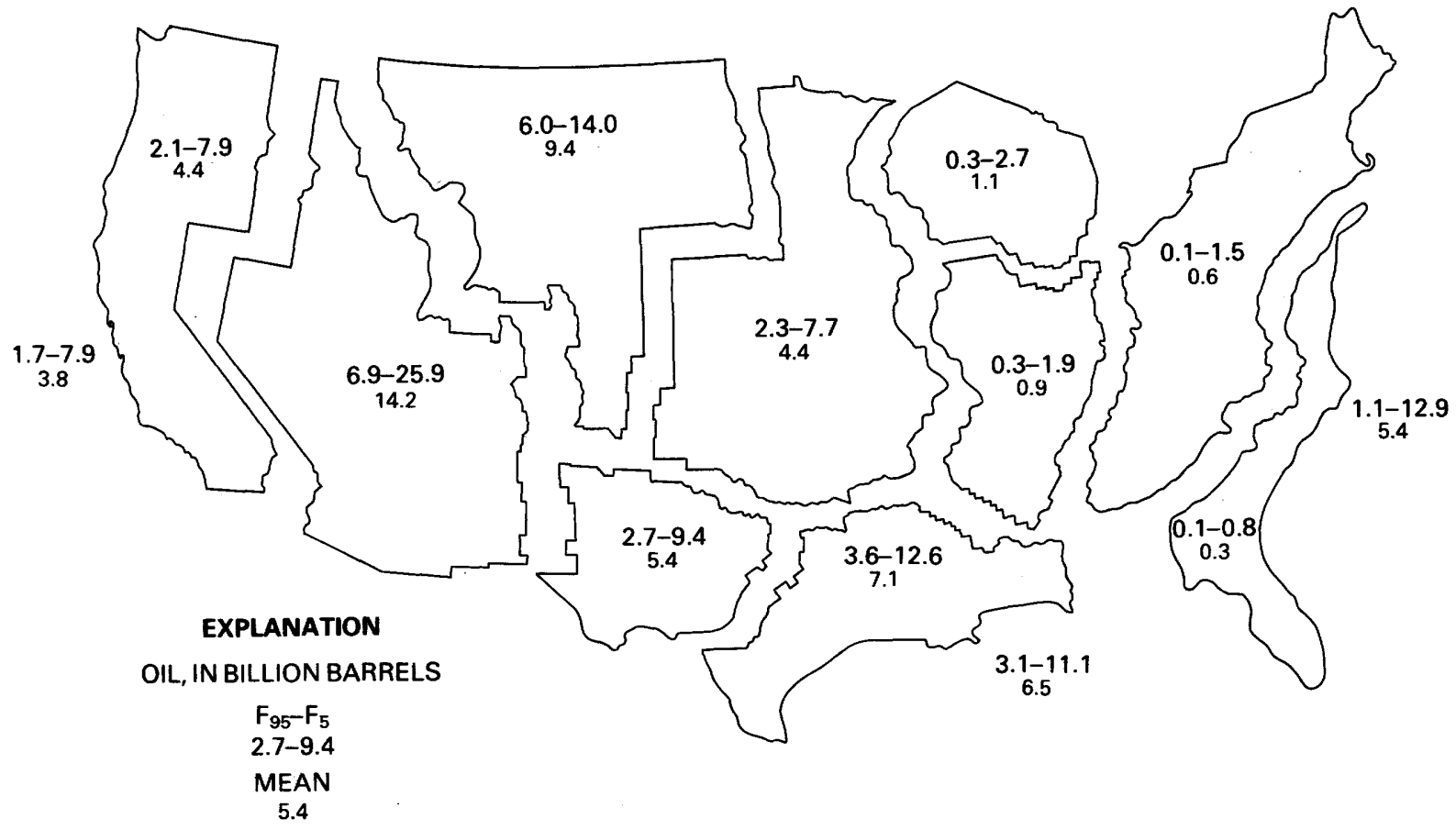

64.3-105.1

82.6
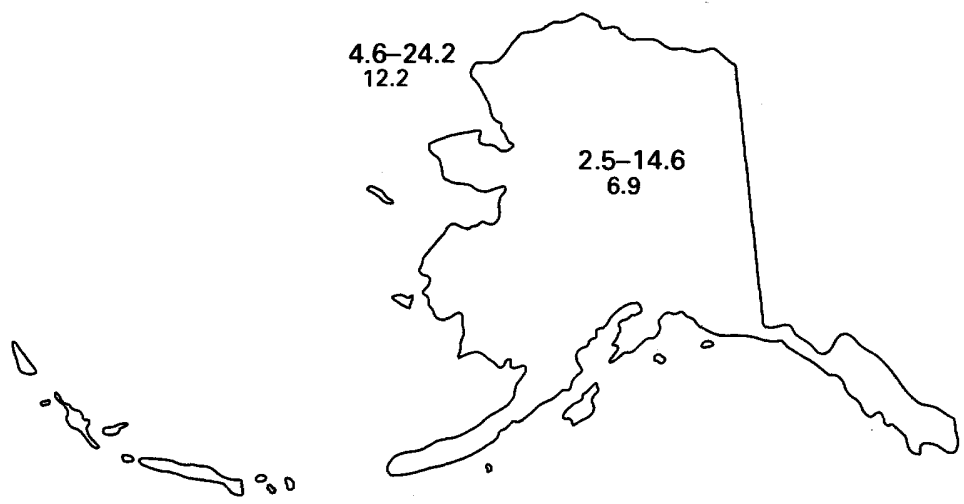

ENTIRE UNITED STATES

INCLUDING ALASKA

AND OFFSHORE

Figure 13.--Crude oil--Ranges and means of undiscovered recoverable resource by Region. (See fig. 3 for No. and name.) 
and produced quantities provide a frame of reference for the estimates of undiscovered resources.

The undiscovered recoverable oil of the United States is estimated to range from 64.3 to 105.1 billion barrels with a mean estimate of 82.6 billion barrels. The undiscovered recoverable gas is estimated to range from 474.6 to 739.3 trillion cubic feet with a mean estimate of 593.8 trillion cubic feet. Each range corresponds to 95 percent and 5 percent probabilities of more than the respective amounts.

The geographic distribution of estimated undiscovered resources is shown graphically in figures 13 and 14 and is further compared as percentage distributions in figures 15 and 16 . Resources are not uniformly distributed; a few Regions contain most of the estimated undiscovered oil and gas. First, 66 percent of the mean estimate for undiscovered oil and 72 percent for gas is onshore. Almost 90 percent of the onshore potential is found in 6 of the 11 Regions (namely 1 and 3 through 7). Similarly, of the offshore Regions, the Gulf of Mexico plus Alaska contain 67 percent of the oil potential and 82 percent of the gas potential. Analysis of the detailed tables of province estimates in Appendixes $C$ and $D$ indicates that commonly a few individual provinces in each of the Regions (for
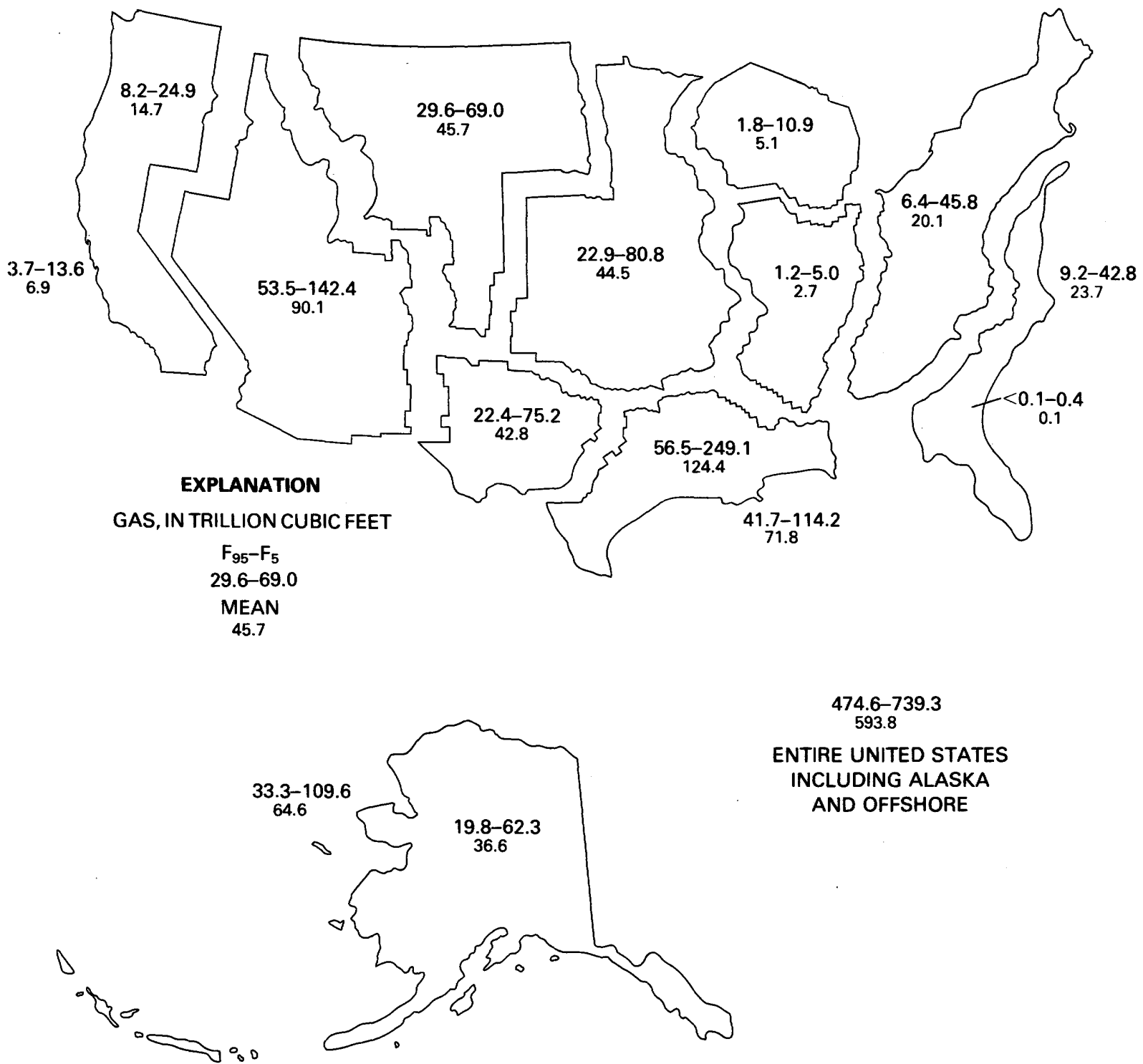

474.6-739.3

593.8

ENTIRE UNITED STATES

INCLUDING ALASKA

AND OFFSHORE

Figure 14.--Total natural gas--Ranges and means of undiscovered recoverable resource by Region. (See fig. 3 for No. and name.) 
example, the Wyoming-Utah-Idaho overthrust belt of Region 3) account for most of the potential in those Regions.

Figures 17 and 18 show regional distribution of mean estimates of undiscovered recoverable resources, as well as the distribution of discovered amounts of oil and gas. Most mature areas have amounts of undiscovered resources that are approximately equal to reserves. Frontier provinces are characterized by high undiscovered to discovered ratios, as in Regions 3 and 4 and in the offshore Regions exclusive of the Gulf of Mexico. The relatively low proportion of undiscovered to discovered quantities in onshore frontier Alaska (Region 1) is controlled by the presence of a single giant field, Prudhoe Bay, making Alaska appear similar to mature provinces in this respect. However, large amounts of oil and gas also remain undiscovered in some more maturely explored Regions, such as the Gulf Coast and the Gulf of Mexico.

Although it is convenient to use a point estimate, such as the mean, as a basis for comparison, a range of values (or interval estimate) more properly expresses the uncertainty inherent in estimates of undiscovered resources. Point estimates may convey an impression of exactness that is highly misleading. Aggregate probability distributions for undiscovered recoverable oil and gas for the United States are presented in figures 19 and 20, and show the amounts of resources and the respective probabilities of more than those amounts.

Although the oil ranges from 64.3 billion barrels (the 95th fractile) to 105.1 billion barrels (the 5 th fractile), and gas ranges from 474.6 trillion cubic ft to 739.3 trillion cubic ft; lower or higher amounts (fractiles) may be read directly from the curves. Appendix A contains the aggregate probability distributions.

Table 8 presents mean estimates of undiscovered recoverable resources of NGL in the United States. These amounts were calculated by the procedures explained on p. 22 . Natural gas liquids are a significant component of the total liquid hydrocarbons. They add approximately 17.7 billion barrels, on a mean estimate basis, to the assessed crude oil estimate of 82.6 billion barrels, and constitute approximately 18 percent of total liquids.

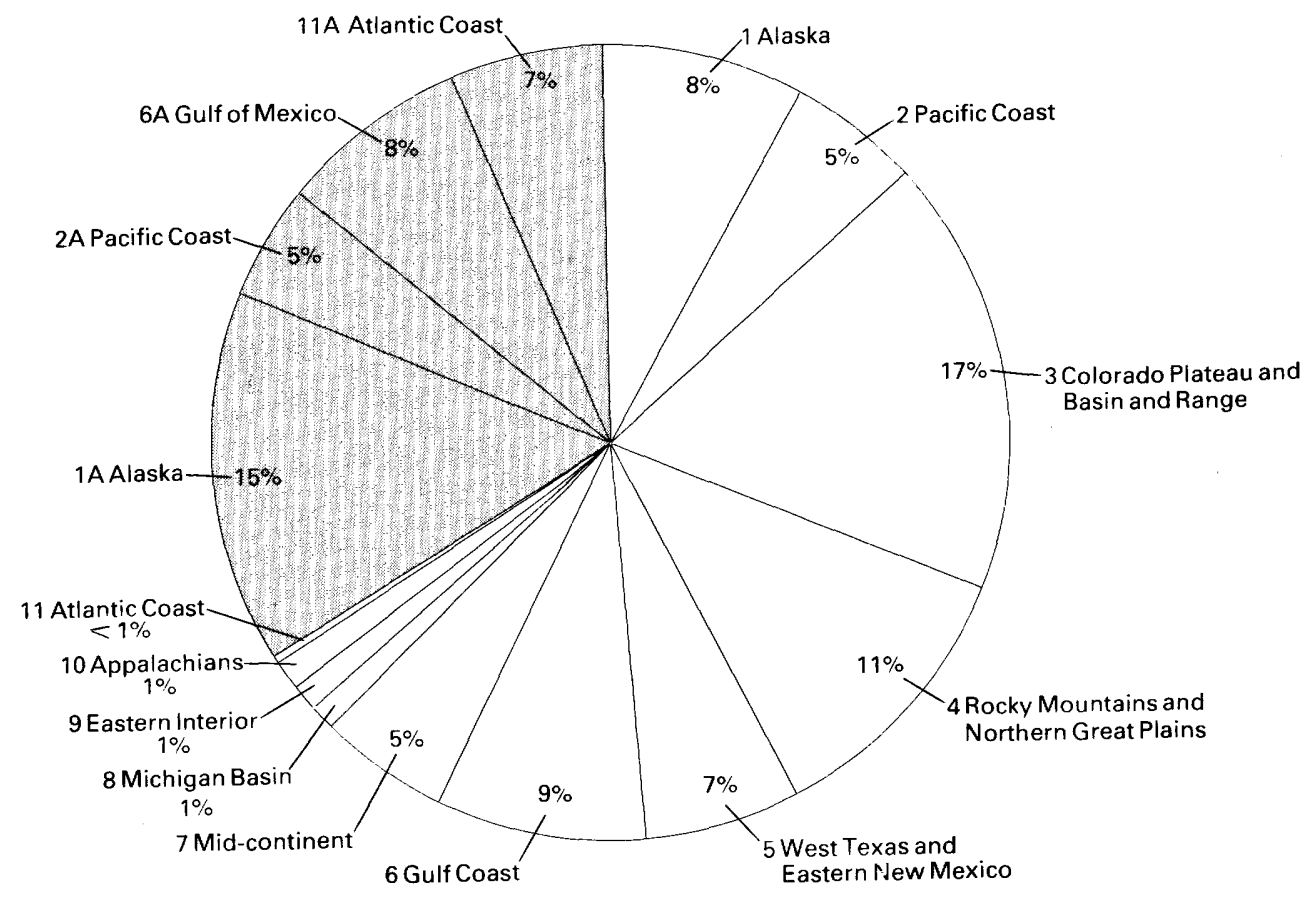

EXPLANATION

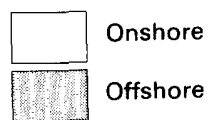

Figure 15.--Crude oil--Undiscovered recoverable resource by Region as percentage of the total estimate for the United States, based on mean estimates. 
Comparison of Recent Hydrocarbon Resource Estimates

Many estimates of United States recoverable oil and gas resources have been published since 1909, and have been compared by McCulloh (1973), Miller and others (1975), Sheldon (1976), Potential Gas Committee (1977a), and Masters (1979). Selected estimates appearing since 1970 are reviewed here (figs. 21 and 22). Direct comparison among these estimates is difficult for the following resasons:

1. Inclusion or exclusion of important areas, such as Alaska;

2. Differences in offshore areas as defined by different water depths;

3. Inclusion or exclusion of natural gas liquids in the estimates of crude oil;

4. Inclusion or exclusion of inferred reserves;

5. Assessment of quantities other than recoverable quantities; and

6. Differences in type of reported statistic (mean, mode, range, "expected value", etc.), or that the type of statistic is not explained.
Prior to 1975, there were several estimates that had values greater than 200 billion barrels of oil. Since 1975, however, as shown in figure 21, there has been a general consensus concerning the order of magnitude of undiscovered resources. Interval estimates generally overlap, and, excluding Nehring's (1981) estimates, the point estimates range from 55 to 113 billion barrels.

An examination of natural gas estimates (fig. 22) suggests a similar tendency toward consensus. The interval estimates published since 1975 also generally overlap; the point estimates, exclusive of Nehring (1981), range from 287 to 820 trillion cubic feet.

Some significant differences exist between the estimates presented in our report and those published by the USGS in 1975 (Miller and others). These differences essentially reflect the results of new data and new concepts. For example, results of exploratory drilling in some relatively unexplored areas, particularly the Gulf of Alaska, southern California borderland, and south Atlantic shelf have been disappointing, and geologic information obtained from those provinces indicates reduced

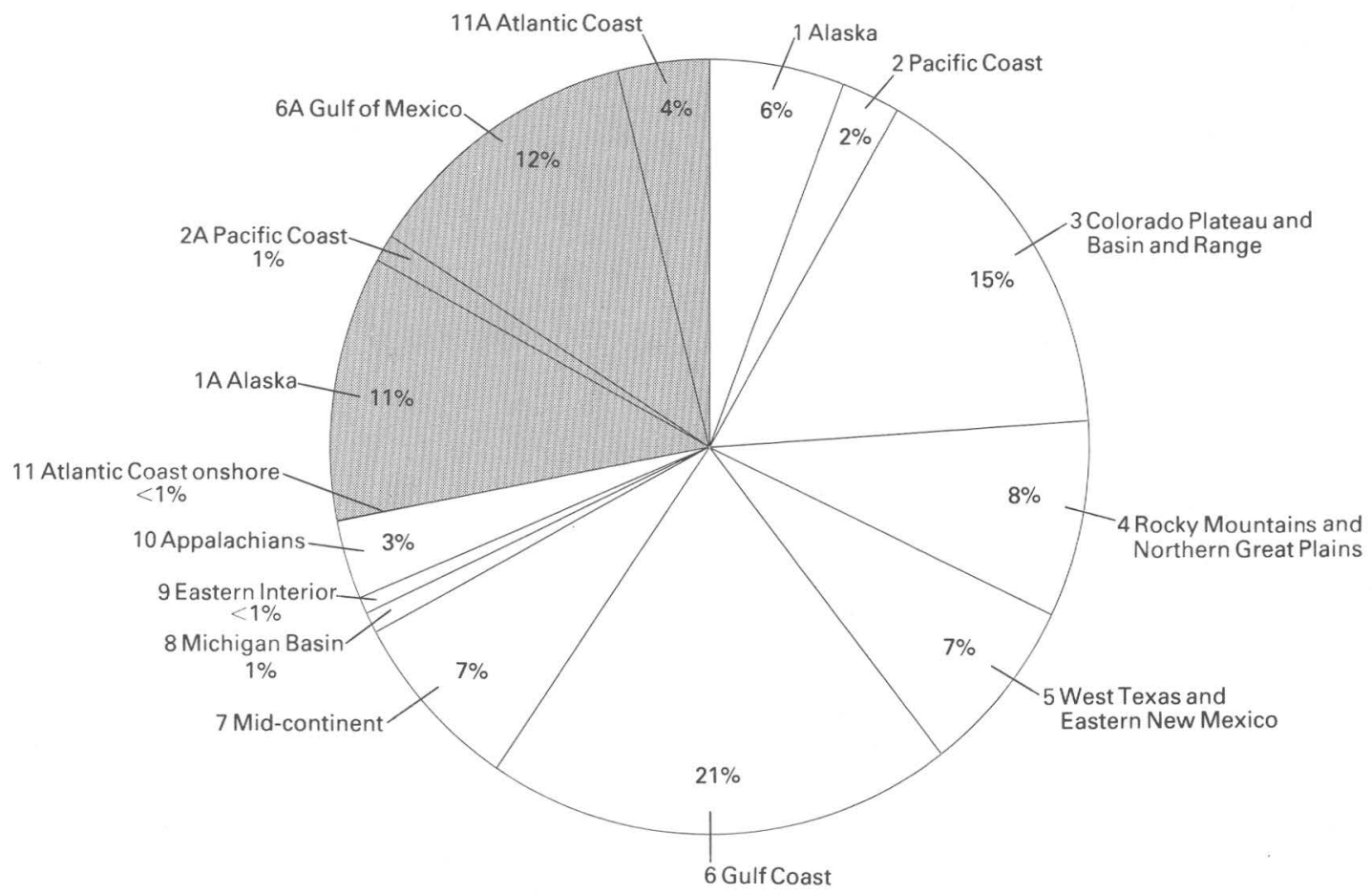

EXPLANATION

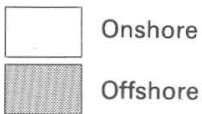

Figure 16.--Natural gas--Undiscovered recoverable resource by Region as percentage of the total estimate for the United States, based on mean estimates. 


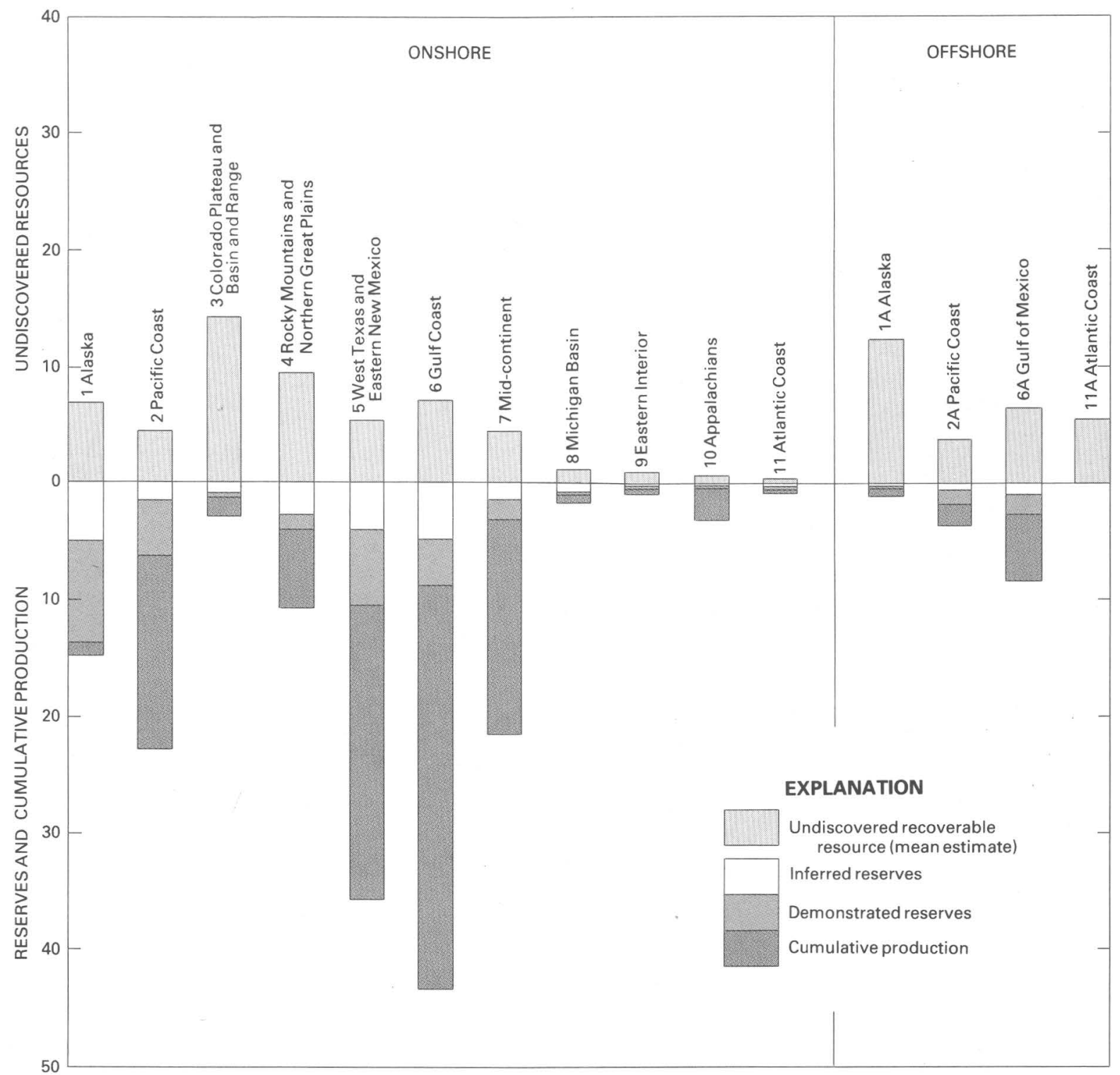

Figure 17.--Crude oil--Estimates of discovered amounts (cumulative production and reserves) and undiscovered amounts (mean estimates) in billion barrels by Region. 


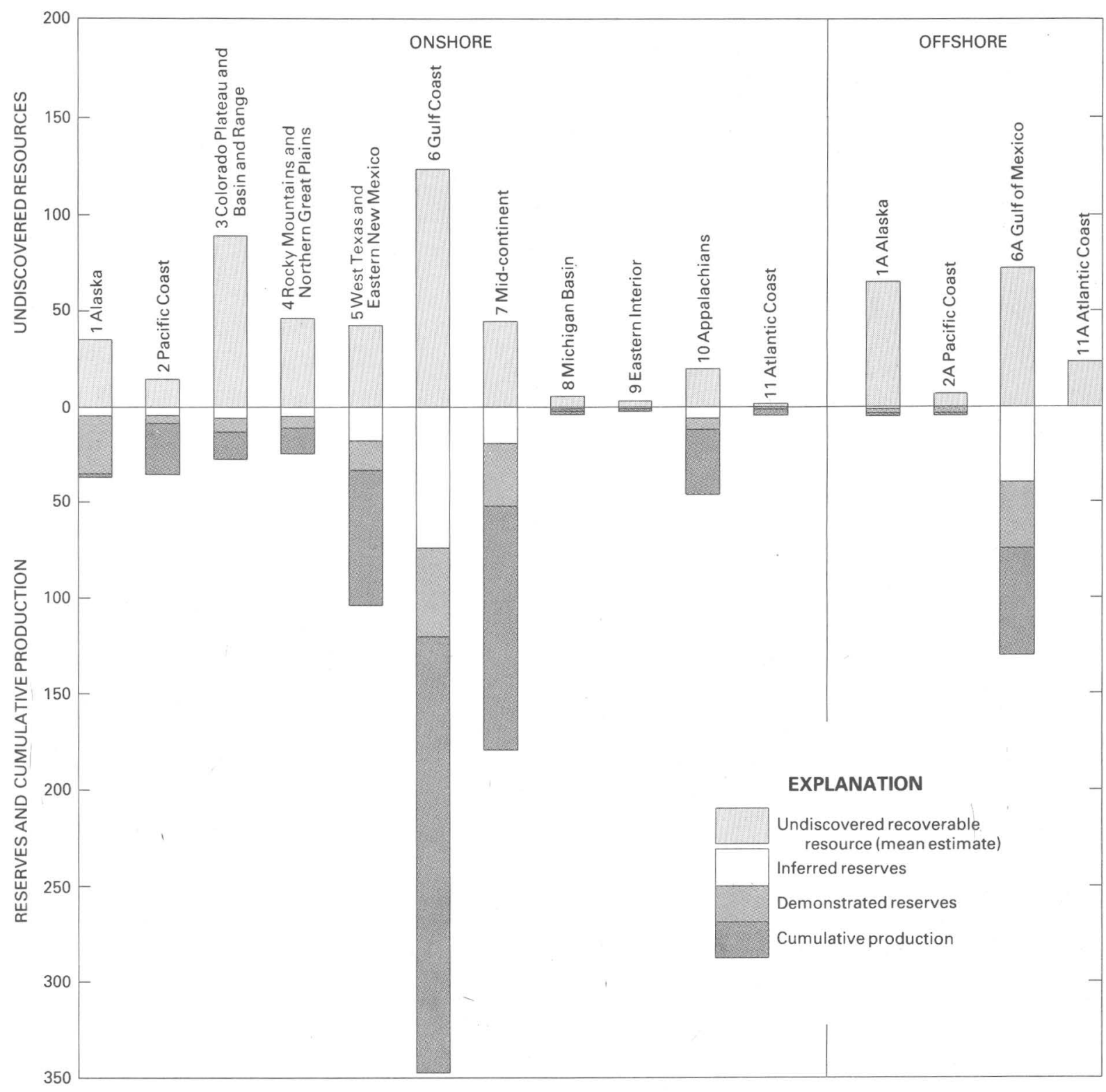

Figure 18.--Natural gas--Estimates of discovered amounts (cumulative production and reserves) and undiscovered recoverable amounts (mean estimates) in trillion cubic feet by Region. 


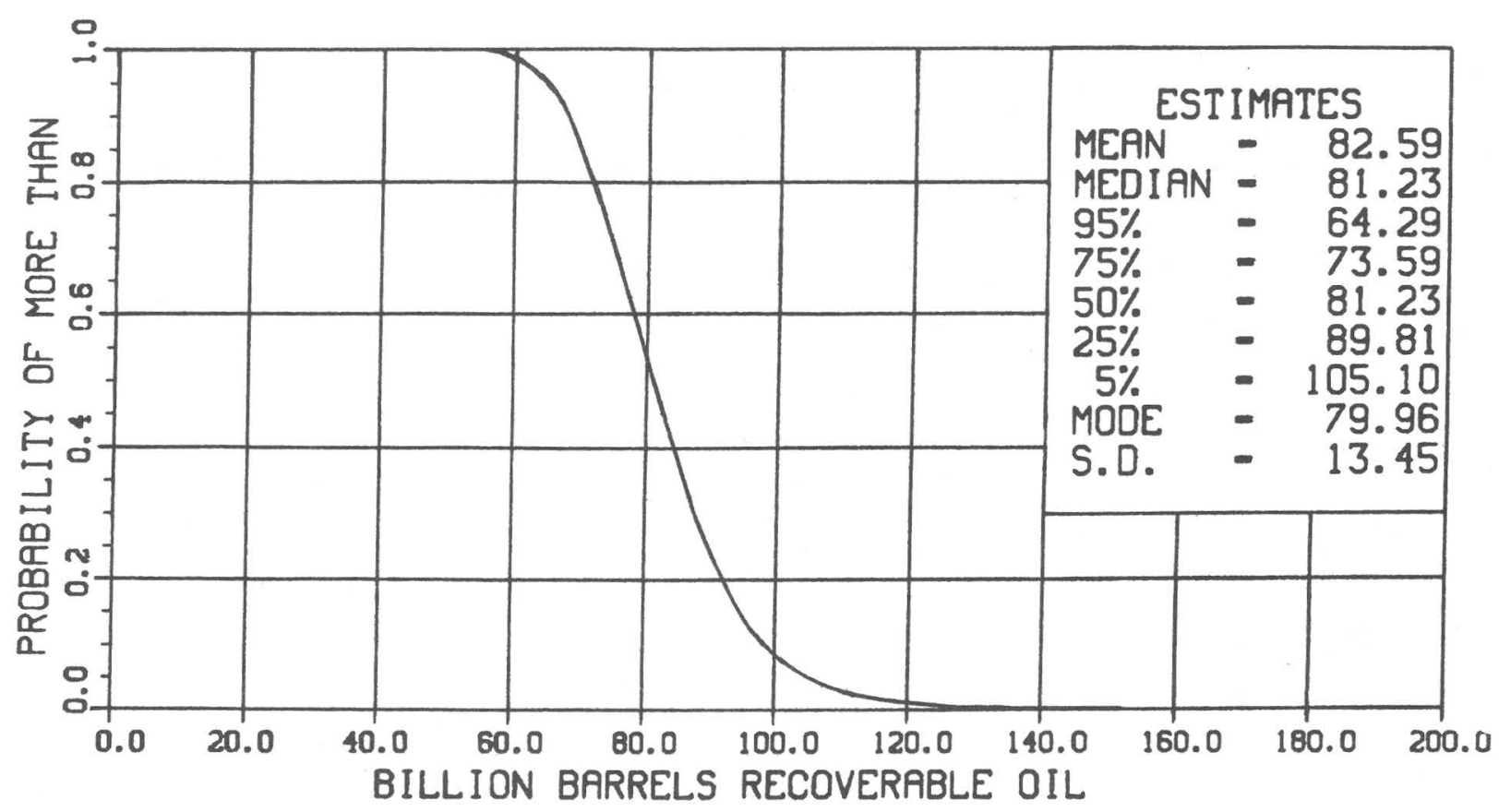

Figure 19.--Crude oil--Probability distribution of the undiscovered recoverable resources for the United States. Estimates are mean, median, mode, standard deviation (S.D.), and fractiles that correspond to the percentages listed.

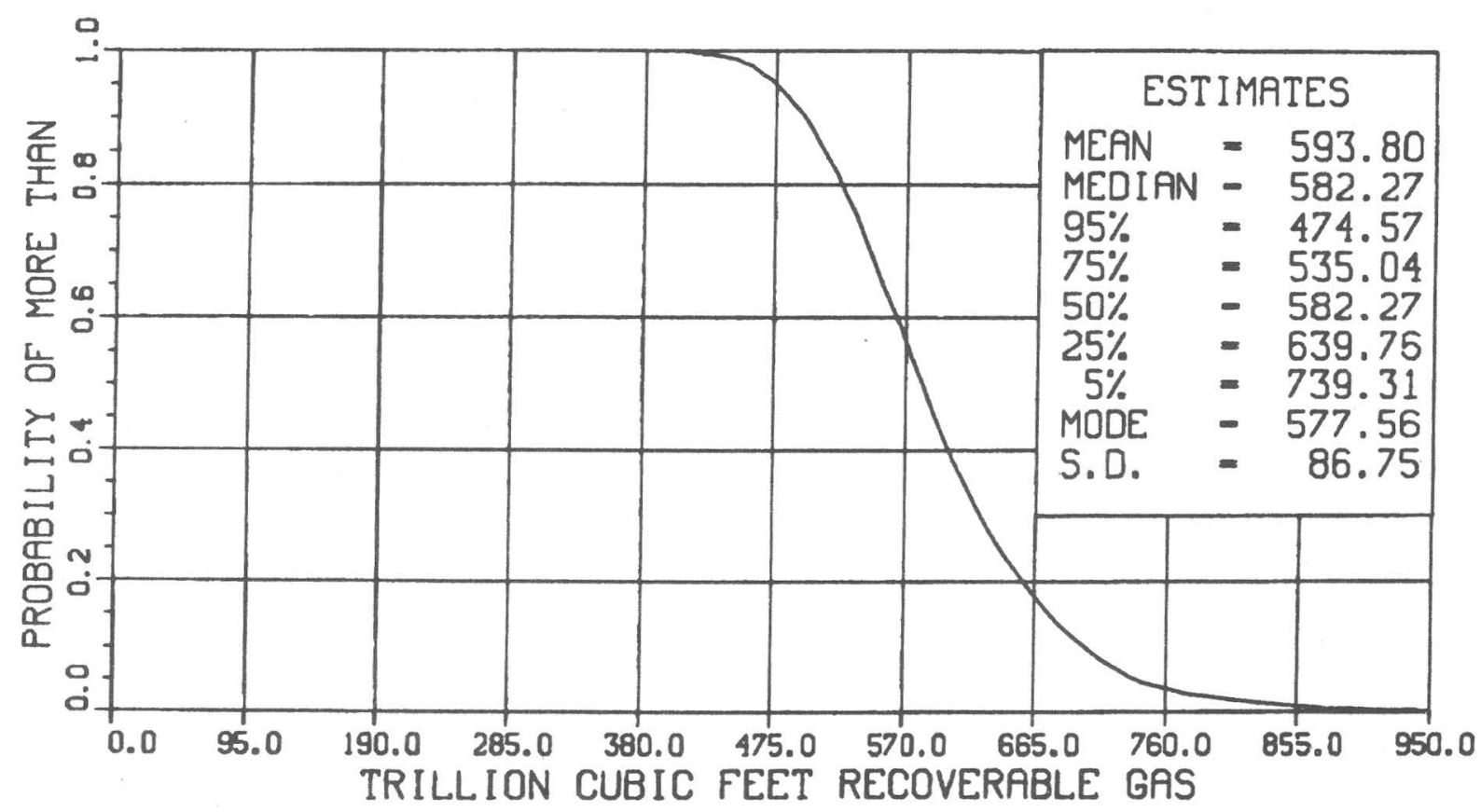

Figure 20.--Natural gas--Probability distribution of the undiscovered recoverable resources for the United States. Estimates are mean, median, mode, standard deviation (S.D.), and fractiles that correspond to the percentages listed. 


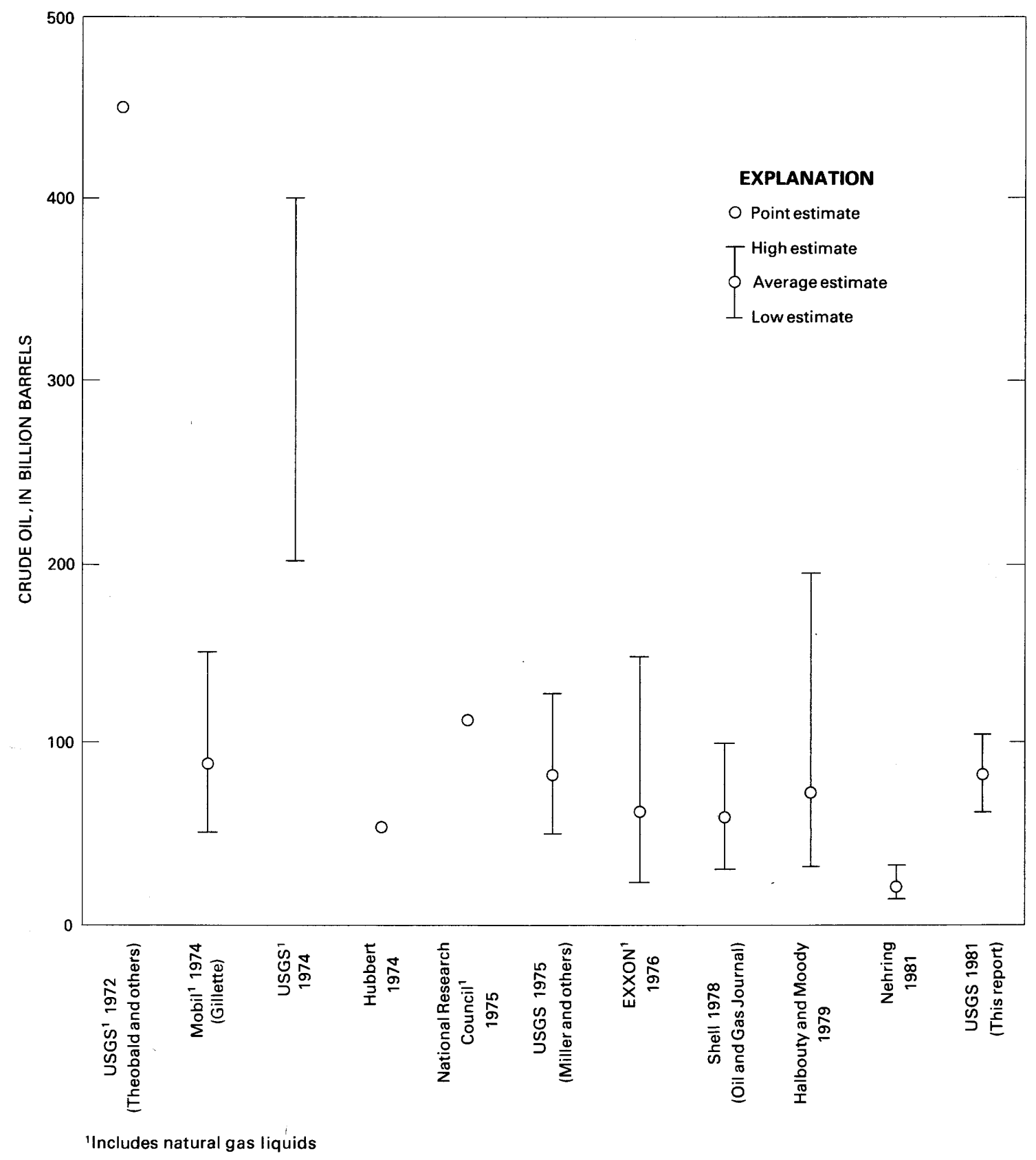

Figure 21.--Crude oil--Selected estimates of undiscovered recoverable resources for the United States. 


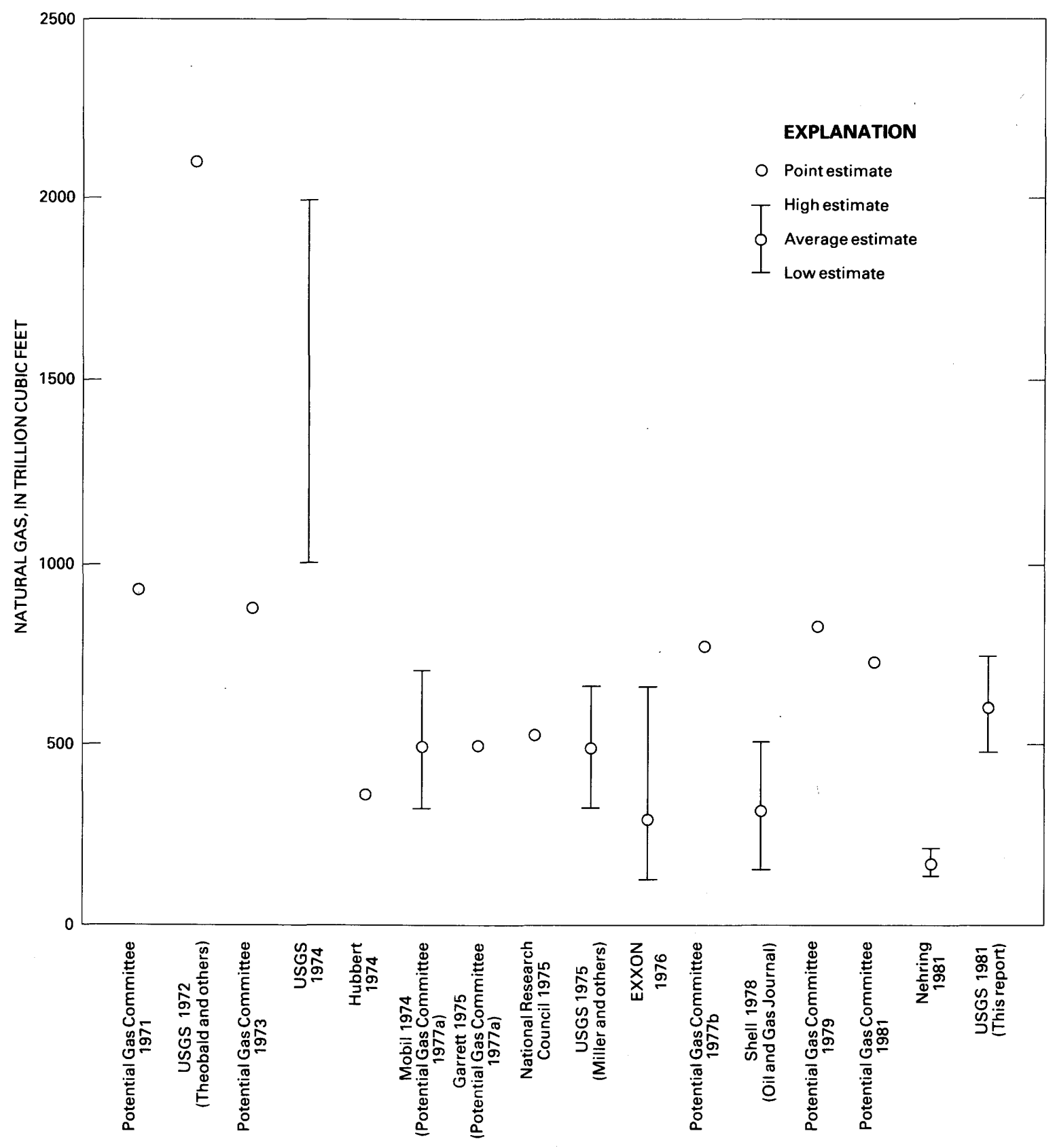

Figure 22.--Natural gas--Selected estimates of undiscovered recoverable resources for the United States. Estimate for the Potential Gas Committee is their "possible" plus their "speculative" estimates. 
hydrocarbon potential. Drilling since 1975 in the Cordilleran overthrust belt of the western United States (Regions 3 and 4), on the other hand, has indicated a large potential for both oil and gas in this area, and also has changed the concept of the potential of other thrust belts. In addition, note that the continental slope is included in the area of the current assessment, but was excluded from the 1975 study .

\section{CONCLUSIONS}

The purpose of this study was to estimate the quantities of conventional oil and natural gas that may be available for discovery and recovery. No attempt was made to predict what part of the assessed quantities will be discovered or when. Because of uncertainties involved in resource estimation, estimates are reported as a range of values. The low value corresponds to a 95 percent probability of more than that amount (95th fractile, $\mathrm{F}_{95}$ ) and the high value corresponds to a 5 percent probability of more than that amount ( $5 \mathrm{th}$ fractile, $\mathrm{F}_{5}$ ).

The current appraisal gives a mean estimate of undiscovered recoverable crude oil in the United States as 82.6 billion barrels and a range from 64.3 to 105.1 billion barrels, corresponding to the 95 th and 5 th fractile, respectively. The corresponding values for gas are a mean estimate of 593.8 trillion cubic feet and a range from 474.6 to 739.3 trillion cubic feet. The mean value for undiscovered oil is about 47 percent of the total oil discovered to date and the mean value for gas is about 63 percent of the total gas discovered to date. About 66 percent of the undiscovered oil and 72 percent of the undiscovered gas is estimated to occur onshore. The Region with the greatest onshore oil potential is the Colorado Plateau and Basin and Range, which includes the WyomingUtah-Idaho thrust belt. Offshore oil potential
Table 8.--Natural gas liquids (NGL)--Mean estimates of undiscovered recoverable resources in the United States

[A11 tabulated values are rounded from original numbers and may not be precisely additive. Values shown are in billions of barrels. Neg1., negligible, less than or equal to 0.05 billion barrels of NGL (natural gas 1iquids)]

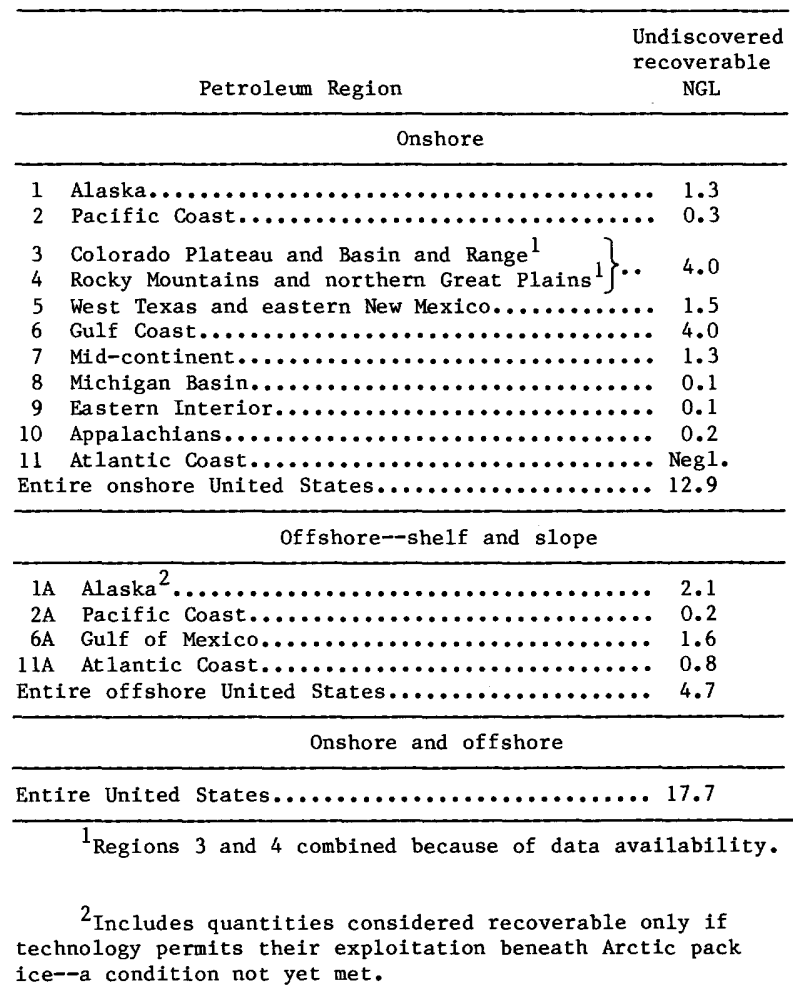

is greatest for Alaska, followed by the Gulf of Mexico and the Atlantic Coast. For gas, the mean values indicate that the Gulf Coast has the greatest potential onshore and that the Gulf of Mexico has the greatest potential offshore. 
Alpha, T. R., and Swenson, Phyl1is, 1978, Equal area base map of Alaska and northeast Siberia: U.S. Geological Survey Open-File Report 78-82, scale 1:5,000,000, 1 sheet.

American Association of Petroleum Geologists, 1969, Circum-Gulf of Mexico issue: American Association of Petroleum Geologists Bulletin, v. 53, no. 12, p. 2399-2558.

American Association of Petroleum Geologists Committee on Statistics of Drilling, compilers, in cooperation with the U.S. Geological Survey, 1978, Alaska geologic province boundary map: Tulsa, Oklahoma, American Association of Petroleum Geologists, scale approximately 1 inch=60 miles.

*American Petroleum Institute, 1976, Standard definitions for petroleum statistics: Washington, D.C., American Petroleum Institute Technical Report 1, 2d. ed., $40 \mathrm{p}$.

* American Petroleum Institute, American-Gas Association, and Canadian Petroleum Association, 1967-1980, Reserves of crude oil, natural gas liquids, and natural gas in the United States and Canada [annual volumes for the years 1966-1979]: New York, American Petroleum Institute.

Bally, A. W., 1975, A geodynamic scenario for hydrocarbon occurrences: Ninth World. Petroleum Congress Proceedings, v. 2, p. 33-44.

*Bayley, R. W., and Muehlberger, W. R., compilers, 1968, Basement rock map of the United States exclusive of Alaska and Hawaii: Washington, D.C., U.S. Geological Survey, scale $1: 2,500,000,2$ sheets.

Beebe, B. W., and Curtis, B. F., eds., 1968, Natural gases of North America--A symposium in two volumes: American Association of Petroleum Geologists Memoir 9, v. 1, p. 1-1226, v. 2, p. 1227-2493.

Beikman, H. M., compiler, 1978, Preliminary geologic map of Alaska: U.S. Geologica1 Survey, scale 1:2,500,000, 2 sheets.

Burk, C. A., and Drake, C. L, eds., 1974, The geology of continental margins: New York, Springer-Verlag, 1009 p.

*California Division of 011 and Gas, 1980, 65th Annual Report of the State oil and gas supervisor, 1979: California Division of Oil and Gas, Publication No. PR06, $162 \mathrm{p}$.

Committee on Statistics of Exploratory Drilling, 1946-1966, Exploratory drilling in 19451965: American Association of Petroleum Geologists Bulletin, v. 30, no. 6 to v. 50, no. 6 .

Committee on Statistics of Exploratory Drilling, 1967-1980, North American drilling activity 1966-1979: American As sociation of
Petroleum Geologists Bulletin, v. 51-54, no. 6; v. 55-56, no. 7; v. 57-63, no. 8; v. 64 , no. 9 .

*Cram, I. H., ed., 1971, Future petroleum provinces of the United States--Their geology and potential: American Association of Petroleum Geologists Memoir 15, v. 1, p. 1-803; v. 2, p. 805-1496.

*Crovelli, R. A., 1981, Probabilistic methodology for oil and gas resource appraisal: U.S. Geological Survey OpenFile Report 81-1151, 77 p.

Diment, W. H., and Urban, T. C., 1981, An average elevation map of the conterminous United States (Gilluly averaging method): U.S. Geological Survey Geophysical Investigations Map GP-933, scale $1: 2,500,000,2$ sheets.

*Dolton, G. L., Carlson, K. H., Charpentier, R. R., Coury, A. B., Crovelli, R. A., Frezon, S. E., Khan, A. S., Lister, J. H., McMullen, R. H., Pike, R. S., Powers, R. B., Scott, E. W., and Varnes, K. L., 1981, Estimates of undiscovered recoverable resources of conventionally producible oil and gas in the United States, a summary: U.S. Geological Survey Open-File Report $81-192,17 \mathrm{p}$.

Eardley, A. J., 1962, Structural geology of North America (2d ed.): New York, Harper Brothers, $624 \mathrm{p}$.

Emmerich, H. H., ed., 1974, Selected papers from East Coast offshore symposium, Baffin Bay to the Bahamas: American Association of Petroleum Geologists Bulletin, v. 58, no. 6, pt. 2 of 2, p. 1055-1240.

*Exxon Company, U.S.A., Exploration department, 1976, U.S. oil and gas potential: Exxon Company, U.S.A., 10 p. (March 1976).

*Geothermal Survey of North America Subcommittee of the American Association of Petroleum Geologists Research Committee, 1976, Geothermal gradient map of North America: American Association of Petroleum Geologists and U.S. Geological Survey, scale 1:5,000,000, 2 sheets.

*Gillette, R., 1974, Oil and gas resources--Did the USGS gush too high?: Science, v. 185, no. 4146, p. 127-130.

Grantz, Arthur, Holmes, M. L., and Kososki, B. A., 1975, Geologic framework of the Alaskan continental terrace in the Chukchi and Beaufort Seas, in Yorath, C. J., Parker, E. R., and Glass, D. J., eds., Canada's continental margins and offshore petroleum exploration: Canada Society of Petroleum Geologists Memoir 4, Calgary, Alberta, Canada, p. 669-700.

Grantz, Arthur, and Kirschner, C. E., 1976, Tectonic framework of petroliferous rocks in Alaska, in Circum-Pacific energy and 
mineral resources: American Association of Petroleum Geologists Memoir 25, p. 291-307.

Halbouty, M. T., ed., Geology of giant petroleum fields--A symposium: American Association of Petroleum Geologists Memoir 14, 575 p.

*Halbouty, M. T., and Moody, J. D., 1980, World ultimate reserves of crude oil: 10th World petroleum congress, Bucharest, 1979, Proceedings, v. 2, p. 291-301.

Harbaugh, J. W., Doveton, J. H., and Davis, J. C., 1977, Probability methods in oil exploration: New York, John Wiley, 269 p.

Haun, J. D., ed., 1975, Methods of estimating the volume of undiscovered oil and gas resources: American Association of Petroleum Geologists, Studies in Geology, no. 1, $206 \mathrm{p}$.

*Hayes, K. H., 1976, A discussion of the geology of the southeastern Canadian Cordillera and its comparison to the Idaho-Wyoming-Utah fold and thrust belt, in Hill, J. G., ed., Geology of the Cordilleran hinge 1ine: Rocky Mountain Association of Geologists, 1976, Symposium, p. 59-82.

*Hendricks, T. A., 1965, Resources of oil, gas, and natural-gas 1 iquids in the United States and the world: U.S. Geological Survey Circular 522, 20 p.

Hillier, F. S., and Lieberman, G. J., 1980, Introduction to Operations Research: San Francisco, Holden-Day, Inc., 3d ed. 829 p. Howe11, D. G., McCulloch, D. S., and Vedder, J. G., 1978, General geology, petroleum appraisal, and nature of environmental hazards, eastern Pacific shelf, latitude $28^{\circ}$ to $38^{\circ}$ north: U.S. Geological Survey Circular 786, 29 p.

Hubbert, M. K., 1967, Degree of advancement of petroleum exploration in United States: American Association of Petroleum Geologists Bulletin, v. 51, no. 11, p. 2207-2227.

* 1974, U.S. energy resources, a review as of 1972, pt. 1, in A national fuels and energy policy study: U.S. 93rd. Congress, 2d. session, Senate Committee on Interior and Insular Affairs, Committee Print, Serial no. 93-40 (92-75), 267 p.

Independent Petroleum Association of America, [1980], The oil producing industry in your State, 1979 ed.: Washington, D.C., Independent Petroleum Association of America, 119 p.

*International Oil Scouts Association, 19451978, International oil and gas development yearbooks, 1944-1977: Austin, Texas, International $0 i 1$ Scouts Association, v. 15-48.

Jones, D. L., and Silberling, N. J., 1979, Mesozoic stratigraphy--The key to tectonic analysis of southern and central Alaska: U.S. Geological Survey Open-File Report $79-1200,37 \mathrm{p}$.

*Kali1, F. F., 1980, Estimated oil and gas reserves, southern California outer continental shelf, December 31, 1979: U.S. Geological Survey Open-File Report 80-1042, $8 \mathrm{p}$.

Kaufman, G. M., 1963, Statistical decision and related techniques in oil and gas exploration: Englewood Cliffs, New Jersey, Prentice-Ha11, $307 \mathrm{p}$.

*King, P. B., compiler, 1969, Tectonic map of North America: U.S. Geological Survey, scale $1: 5,000,000,2$ sheets.

*King, P. B., and Beikman, H. M., compilers, and Edmonston, G. J., cartographer, 1974, Geologic map of the United States: U.S. Geological Survey, scale $1: 2,500,000,2$ sheets and legend.

*King, P. B., and Edmonston, G. J., 1972, Generalized tectonic map of North America: U.S. Geological Survey Miscellaneous Geologic Investigations Map I-688, scale $1: 15,000,000,1$ sheet.

King, R. E., ed., 1972, Stratigraphic oil and gas fields: American Association of Petroleum Geologists Memoir 16, 687 p.

*Klemme, H. D., 1975, Giant oil fields related to their geologic setting--A possible guide to exploration: Bulletin of Canadian Petroleum Geology, v. 23, no. 1, p. 30-66.

* 1980, Petroleum basins--Classifications and characteristics: Journal of Petroleum Geology, v. 3, no. 2, p. 187-207.

Lahee, F. H., 1962, Statistics of exploratory drilling in the United States, 1945-1960: Tulsa, Oklahoma, American Association of Petroleum Geologists, 135 p.

Landes, K. K., 1970, Petroleum geology of the United States: New York, Wiley Interscience, $571 \mathrm{p}$.

Langston, J. D., 1976, A new look at the U. S. oil and gas potential, in Cameron, V. S., ed., Exploration and economics of the petroleum industry, v. 14: New York, Mathew Bender, p. 33-50.

Linstone, H. A., and Turoff, M., eds., 1975, The Delphi method; techniques and applications: Reading, Massachusetts, Addison-Wesley Publishing Company, 620 p.

Maher, J. C., and Applin, E. R., 1971, Geologic framework and petroleum potential of the Atlantic coastal plain and continental shelf: U.S. Geological Survey Professional Paper 659, 98 p.

Marlow, M. S., Cooper, A. K., Parker, A. W., and Childs, J. R., 1979, Isopach map of strata above acoustic basement in the Bering Sea: U.S. Geological Survey Miscellaneous Field Studies Map MF-1164, scale $1: 2,500,000,1$ sheet.

*Masters, C. D., 1979, Recent estimates of U.S. oil and gas resource potential: U.S. Geological Survey Open-File Report 79-236, $19 \mathrm{p}$.

McCrossan, R. G., ed., 1973, The future petroleum provinces of Canada--Their geology and potential: Canadian Society of Petroleum Geologists Memoir 1, 720 p. 
*McCulloh, T. H., 1973, Oil and gas, in Brobst, D. A., and Pratt, W. P., eds., United States mineral resources: U.S. Geological Survey Professional Paper 820, p. 477-496.

*McKelvey, V. E., 1973, Mineral resource estimates and public policy, in Brobst, D. A., and Pratt, W. P., eds., United States mineral resources: U.S. Geological Survey Professional Paper 820, p. 9-19.

Megil1, R. E., 1971, Exploration economics: Tulsa, Oklahoma, Petroleum Publishing Company, 159 p.

1977, An introduction to risk analysis: Tulsa, Oklahoma, Petroleum Publishing Company, 199 p.

Meyer, R. F., ed., 1974, Geologic provinces of the United States: Tulsa, Oklahoma, American Association of Petroleum Geologists, scale 1:5,000,000.

Meyerhoff, A. A., 1967, Future hydrocarbon provinces of the Gulf of Mexico-Caribbean region: Gulf Coast Association of Geological Societies Transactions, v. 27, p. 217-260.

*Miller, B. M., Thomsen, H. L., Dolton, G. L., Coury, A. B., Hendricks, T. A., Lennartz, F. E., Powers, R. B., Sable, E. G., and Varnes, K. L., 1975, Geological estimates of undiscovered recoverable oil and gas resources in the United States: U.S. Geological Survey Circular 725, 78 p.

*Moore, C. L., 1966, Projections of U.S. petroleum supply to 1980, with annex entitzed The Gompertz curve for analyzing and projecting the historic supply patterns of exhaustible natural resources:

Washington, D.C., U.S. Department of the Interior, Office of $0 i 1$ and Gas, $42 \mathrm{p}$.

Nairn, A. E. M., and Stehli, F. G., eds., 1973, Ocean basins and margins: New York, Plenum Press, v. 1, 583 p.

1974, Ocean basins and margins: New York, Plenum Press, v. 2, 598 p.

1975, Ocean basins and margins: New York, Plenum Press, v. 3, 706 p.

*National Research Council, Committee on Mineral Resources and Environment, 1975, Mineral resources and the environment: National Academy of Science, $348 \mathrm{p}$.

*Nehring, Richard, (with Van Driest, E. R., II), 1981, The discovery of significant oil and gas fields in the United States: The Rand Publication Series R-2654/1-USGS/DOE, 2 v., 236 p. (with Appendix v. 2, of 477 p.).

*Neruchev, S. G., 1964, Possiblities of estimating prognostic reserves of oil on a genetic basis: Geologiya Nefti i Gaza, v. 8, no. 7, p. 8-11. [English translation in Petroleum Geology, v. 8, no. 7, p. 368372.]

Newendorp, P. D., 1975, Decision analysis for petroleum exploration: Tulsa, Oklahoma, Petroleum Publishing Company, 668 p.

*Oil and Gas Journal, 1978, She11; Alaska holds 58 percent of future U.S. oil finds: 0il and Gas Journal, v. 76, no. 47, p. 214. Pe1to, C. R., 1973, Forecasting ultimate oil recovery, in Symposium on petroleum economics and evaluation: Society of Petroleum Engineers, American Institute of Mining and Metallurgical Engineers, Dallas section, SPE 4261, p. 45-52.

PennWe11 Publishing Company, 1980, International petroleum encyclopedia 1980: Tulsa, Oklahoma, The Pennwe11 Publishing Company, $464 \mathrm{p}$.

Perry, W. J., Jr., Minard, J. P., Weed, E. G. A., Robbins, E. I., and Rhodehame1, E. C., 1975, Stratigraphy of the At lantic coastal margin of the United States north of Cape Hatteras--A brief survey: American Association of Petroleum Geologists Bulletin, v. 59, no. 9, p. 1529-1548.

Pitcher, M. G., ed., 1973, Arctic geology: American Association of Petroleum Geologists Memoir 19, $747 \mathrm{p}$.

*Potential Gas Committee, 1971, Potential supply of natural gas in the United States (as of December 31, 1970): Golden, Colorado, Potential Gas Agency, Colorado School of Mines, $41 \mathrm{p}$.

* 1973, Potential supply of natural gas in the United States (as of December 31, 1972): Golden, Colorado, Potential Gas Agency, Colorado School of Mines, $48 \mathrm{p}$.

* 1977a, A comparison of estimates of ultimately recoverable quantities of natural gas in the United States: Golden, Colorado, Potential Gas Agency, Colorado School of Mines, 27 p.

$1977 b$, Potential supply of natural gas in the United States (as of December 31, 1976): Golden, Colorado, Potential Gas Agency, Colorado School of Mines, $45 \mathrm{p}$.

1979 , Potential supply of natural gas in the United States (as of December 31, 1978): Golden, Colorado, Potential Gas Agency, Colorado School of Mines, 75 p. 1981, Potential supply of natural gas in the United States (as of December 31, 1980): Golden, Colorado, Potential Gas Agency, Colorado School of Mines, 119 p.

Raiffa, Howard, 1968, Decision analysis-Introductory lectures on choices under uncertainty: Reading, Massachussetts, Addison-Wesley Publishing Company, 309 p.

Ross, S. M., 1972, Introduction to probability models: New York, Academic Press, Inc., $272 \mathrm{p}$.

Schlee, John, Behrendt, J. C., Grow, J. A., Robb, J. M., Mattick, R. E., Taylor, P. T., and Lawson, B. J., 1976, Regional geologic framework off northeastern United States: American As sociation of Petroleum Geologists Bulletin, v. 60, no. 6, p. 926951.

Schumacher, G. M., compiler, 1976, Bathymetric map of the Gulf of Alaska: U.S. Geological Survey Open-File Report 76-822, map scale $1: 2,500,000,2$ sheets. 
*Sheldon, R. P., 1976, Estimates of undiscovered petroleum resources--A perspective: Washington, D.C., U.S. Geological Survey Annual Report, Fiscal year 1975, p. 11-22.

Sheridan, R. E., 1976, Sedimentary basins of the Atlantic margin of North America:

Tectonophysics, v. 36, issue no. 1-3, p. 113-132.

*Smith, Darold, compiler, 1977, 0il and gas production map of the United States: Terra Graphics, 1 sheet, scale approximately 1 inch $=50$ miles.

Smith, M. B., 1964, Map showing distribution and configuration of basement rocks of California: U.S. Geological Survey Oil and Gas Investigations Map OM-215, scale $1: 500,000,2$ sheets.

Spurr, W. A., and Bonini, C. P., 1973, Statistical analysis for business decisions: Homewood, Illinois, Richard D. Irwin, Inc., p. 97-98, 114, 376, 378.

Stauffer, Kent, Adams, Maurice, Habrat, Richard, and Bourgeois, Dan, 1981, Technological feasibility of deep-water drilling and production in the Gulf of Mexico, in Powers, R. B., ed., Geologic framework, petroleum potential, petroleum-resource estimates, mineral and geothermal resources, geologic hazards and deep-water drilling technology of the maritime boundary region in the Gulf of Mexico: U.S. Geological Survey Open-File Report 81-265, p. 62-89.

Taylor, J. C., 1976, Geologic appraisal of the petroleum potential of offshore southern California; the borderland compared to onshore coastal basins: U.S. Geological Survey Circular 730, $43 \mathrm{p}$.

*Theobald, P. K., Schweinfurth, S. P., and Duncan, D. C., 1972, Energy resources of the United States: U.S. Geological Survey Circular 650, 27 p.

U.S. Bureau of Land Management and U.S. Department of the Interior, 1978, Public land statistics: Washington, D.C., U.S. Department of the Interior, $191 \mathrm{p}$.

*U.S. Bureau of Mines and U.S. Geological Survey, 1976, Principles of the mineral resource classification system of the U.S. Bureau of Mines and U.S. Geological Survey: U.S. Geological Survey Bulletin 1450-A, p. A1-A5.

*U.S. Bureau of Mines and U.S. Geological Survey, 1980, Principles of a resource/reserve classification for minerals: U.S. Geological Survey Circular $831,5 \mathrm{p}$.

*U.S. Department of the Interior, office of Minerals Policy and Research Analysis, 1979, Final report of the 105 (b) economic and policy analysis--Alternative overall procedures for the exploration, development, production, transportation and distribution of the petroleum resources of the National Petroleum Reserve in Alaska (NPRA): Washington, D.C., U.S. Department of the Interior, $145 \mathrm{p}$.

*U.S. Geological Survey, 1970, The national atlas of the United States of America: Washington, D.C., U.S. Geological Survey, $417 \mathrm{p}$.

*U.S. Geological Survey, 1974, USGS releases revised U.S. oil and gas resource estimates: Washington, D.C., U.S. Department of the Interior, Geological Survey, News release, March 26, 1974.

Van Ensinga, F. W. B., 1975, Geological time table, 3d. ed.: Amsterdam, Elsevier, 1 sheet.

Varnes, K. L., Coury, A. B., Dolton, G. L., Frezon, S. E., Khan, A. S., Pike, R. S., Powers, R. B., and Scott, E. W., compilers, 1981, Oil and gas resource assessment areas, Geologic Division, 1980, lower 48 United States, Regions 2 through 11, 2A, 6A, and 11A: U.S. Geological Survey, OpenFile Report $81-84$ C, scale $1: 5,000,000,1$ sheet.

Varnes, K. L., Dolton, G. L., and McMullin, R. H., compilers, 1981, Oil and gas resource assessment areas, Geologic Division, 1980, Alaska, Regions 1 and 1A: U.S. Geological Survey Open-File Report 81-84A, scale $1: 5,000,000,1$ sheet.

Varnes, K. L., Dolton, G. L., and Scott, E. W., compilers, 1981, Oil and gas resource assessment areas, Geologic Division, 1980, Pacific Coast, Regions 2 onshore and $2 \mathrm{~A}$ offshore: U.S. Geological Survey Open-File Report $81-84 \mathrm{~B}$, scale $1: 2,500,000,1$ sheet.

Vedder, J. G., Beyer, L. A., Junger, A., Moore, G. W., Roberts, A. E., Taylor, J. C., and Wagner, H. C., 1974, Preliminary report on the geology of the continental borderland of southern California: U.S. Geological Survey Miscellaneous Field Studies Map MF624,34 p., 9 sheets, scales $1: 1,000,000$ and $1: 500,000$.

*V1issides, S. D., and Quirin, B. A., 1964, 0i1 and gas fields of the United States exclusive of Alaska and Hawaii: U.S. Geological Survey, scale $1: 2,500,000,2$ sheets.

Wa1pole, R. E. and Myers, R. H., 1978, Probability and statistics for engineers and scientists: New York, Macmillan Publishing Company, 2d ed., 580 p.

*Weeks, L. G., 1950, Concerning estimates of potential oil reserves: American Association of Petroleum Geologists Bulletin, v. 34, no. 10, p. 1947-1953.

White, D. A., and Gehman, H. M., 1979, Methods of estimating oil and gas resources: American Association of Petroleum Geologists Bulletin, v. 63, no. 12 , p. 2183-2192.

*World Oil, 1981a, Overthrust play sparks depth records: World Oil, v. 192, no. 3 (February 15), p. 145-147.

$1981 \mathrm{~b}$, West Texas gets new production depth record: World Oil, v. 192, no. 3 (February 15), p. 179-180. 


\section{APPENDIX A}

Graphs of aggregate probability distributions for oil, associated-dissolved gas, non-associated gas, and total gas for Regions in the United States 
- 
Appendix A

\section{Aggregate probability distributions}

Graphs showing the aggregate distributions are arranged as listed in the index below. Each illustration includes the distributions for oil, associated-dissolved gas, non-associated gas, and total gas for the area named. Estimates are the mean, median, mode, standard deviation (S.D.), and the fractiles that correspond to the percentages listed.

Onshore Regions

Page

$1 \quad$ Alaska....................................... 44

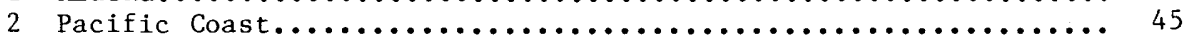

3 Colorado Plateau and Basin and Range................... 46

4 Rocky Mountains and Northern Great Plains................. 47

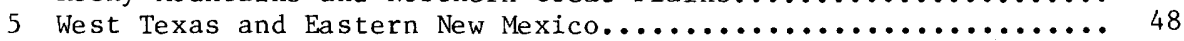

6 Gulf Coast....................................... 49

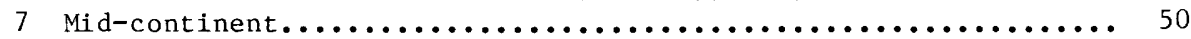

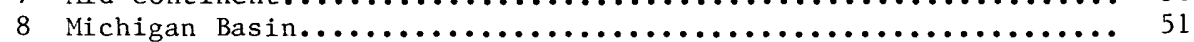

9 Eastern Interior............................... 52

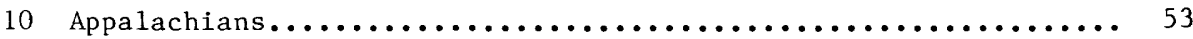

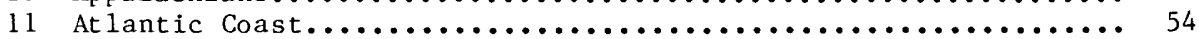

Offshore Regions

1A Alaska:

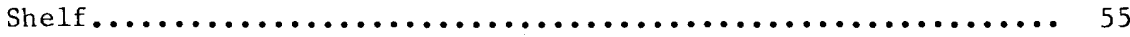

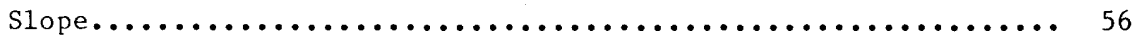

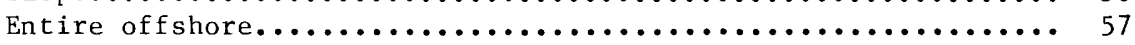

2A Pacific Coast:

Shelf...................................... 58

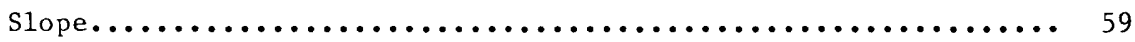

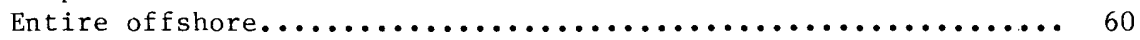

6A Gulf of Mexico:

Shelf ......................................... 61

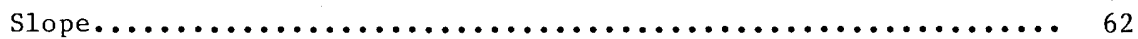

Entire off shore................................. 63

11 Atlantic Coast:

Shelf.......................................... 64

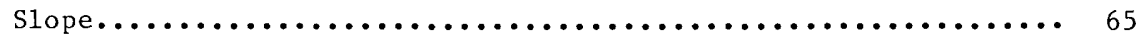

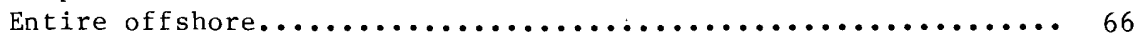

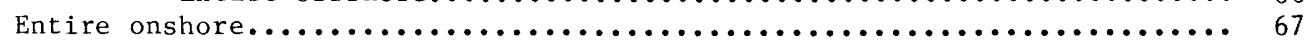

Entire shelf $\ldots \ldots \ldots \ldots \ldots \ldots \ldots \ldots \ldots \ldots \ldots \ldots \ldots \ldots \ldots \ldots \ldots \ldots \ldots \ldots \ldots \ldots \ldots \ldots \ldots \ldots \ldots \ldots \ldots .68$

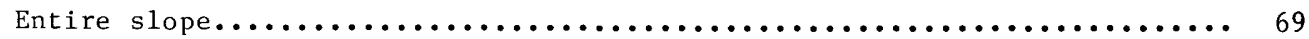

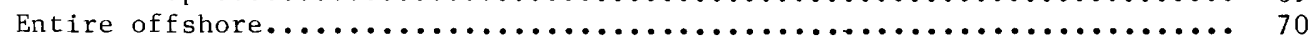

Entire United States..................................... 71 
OIL

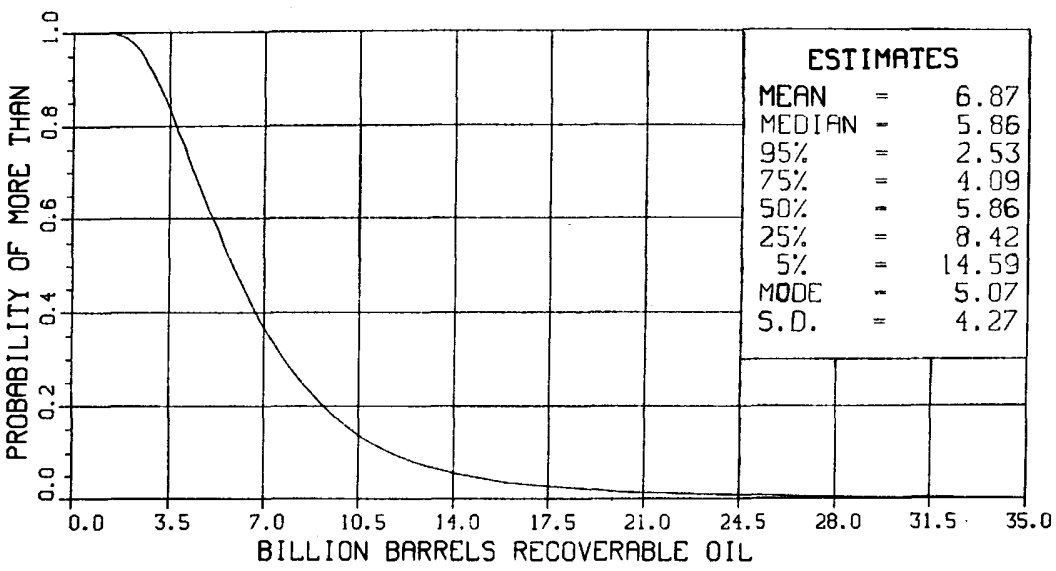

$\$$

\section{ASSOCIATED-DISSOLVED GAS}

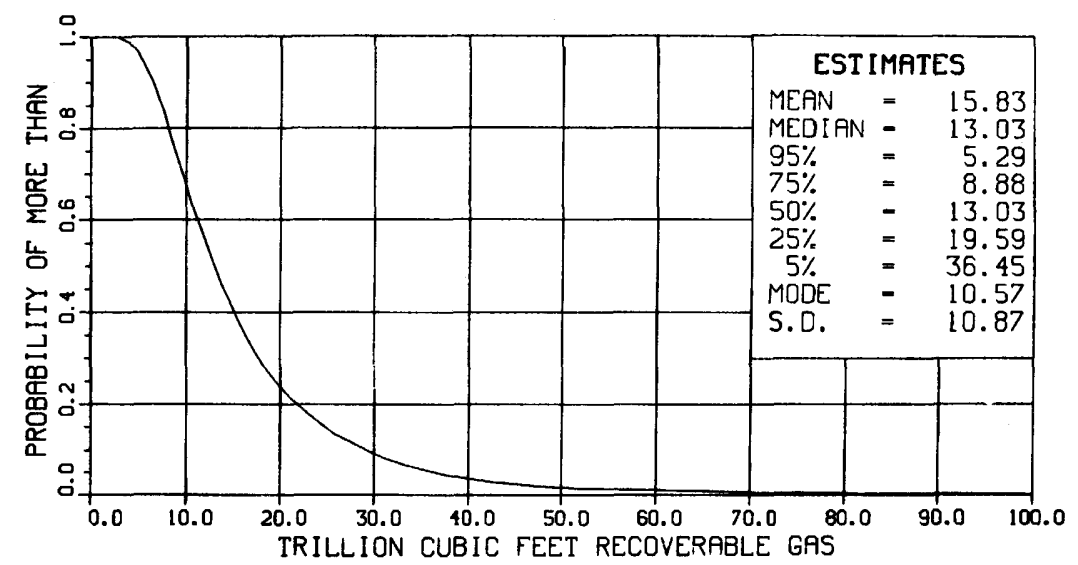

TOTAL GAS

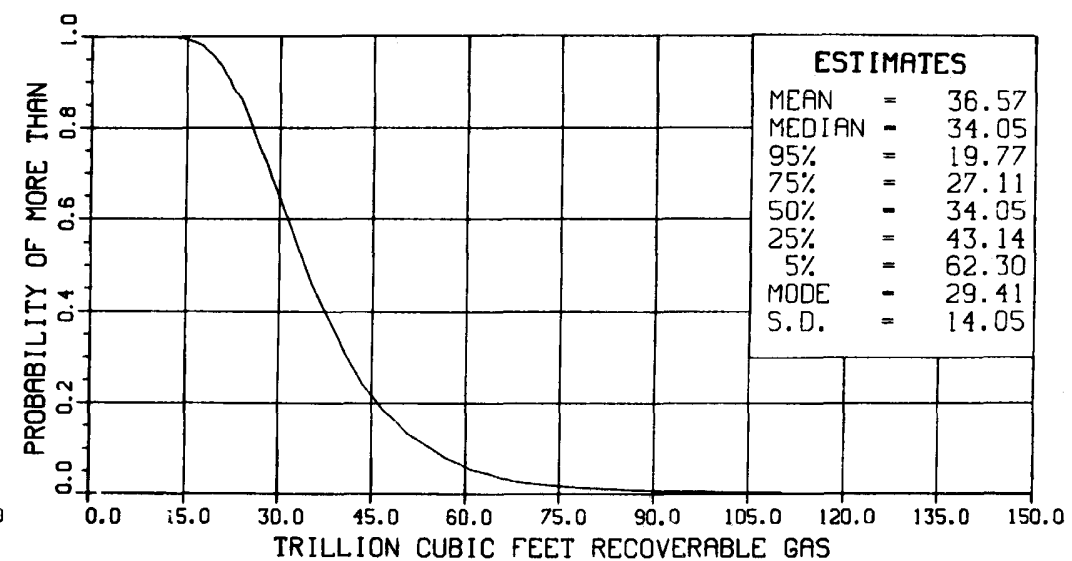

NON-ASSOCIATED GAS

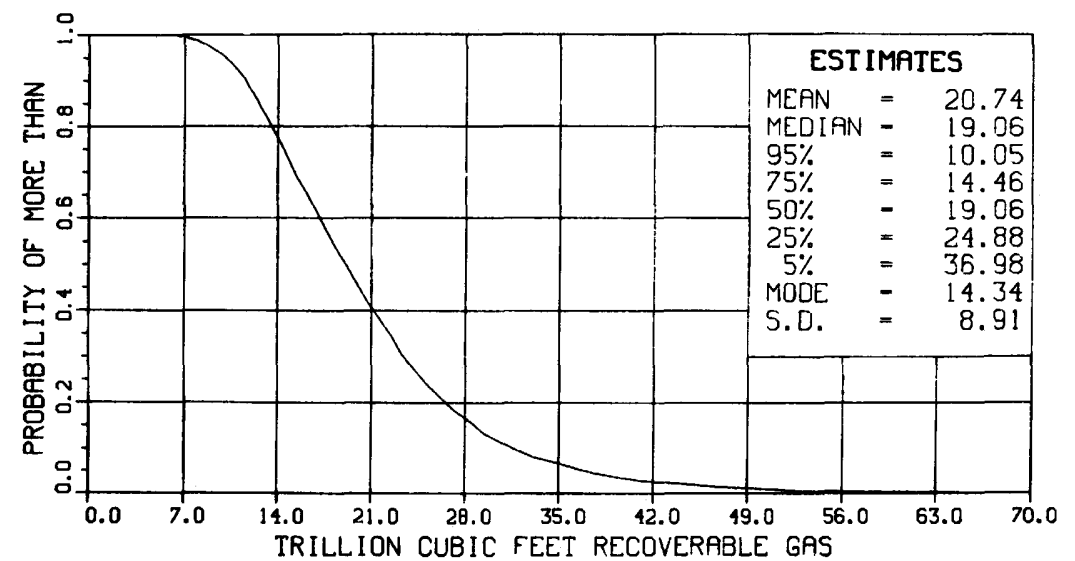

Region 1.--Alaska 
OIL

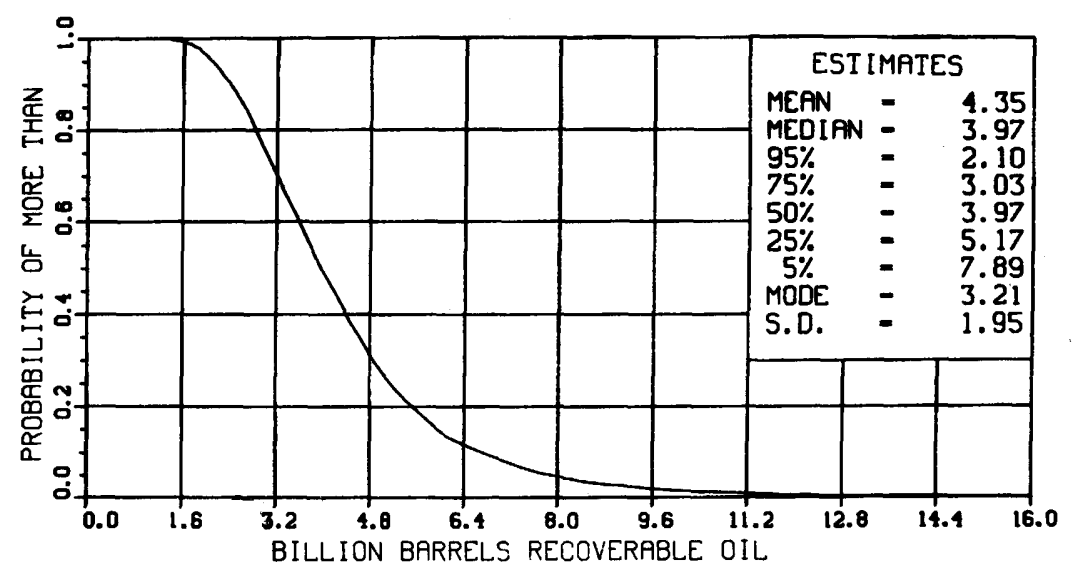

怘 ASSOCIATED-DISSOLVED GAS

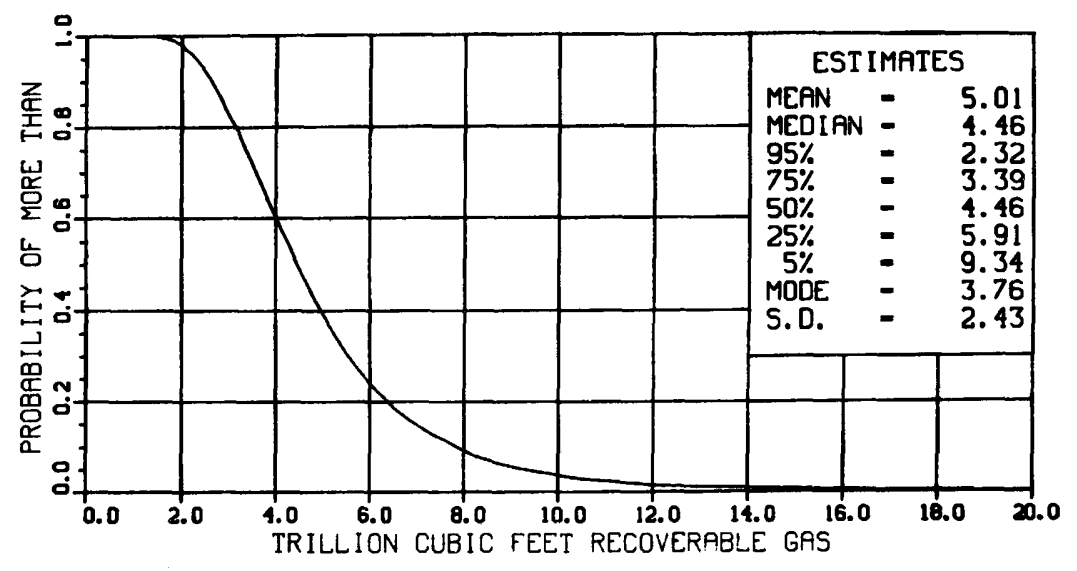

TOTAL GAS

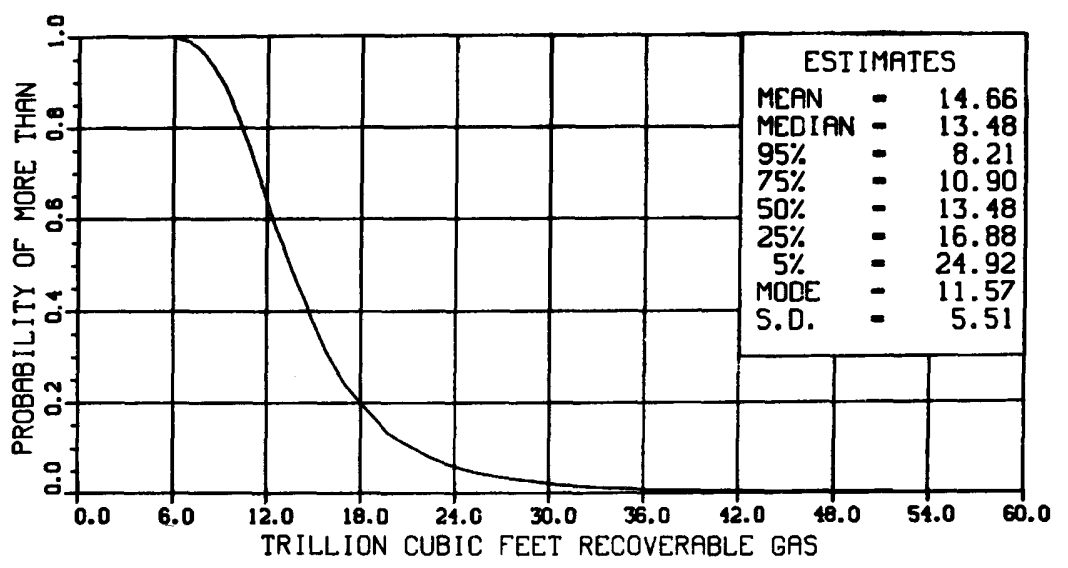

NON-ASSOCIATED GAS

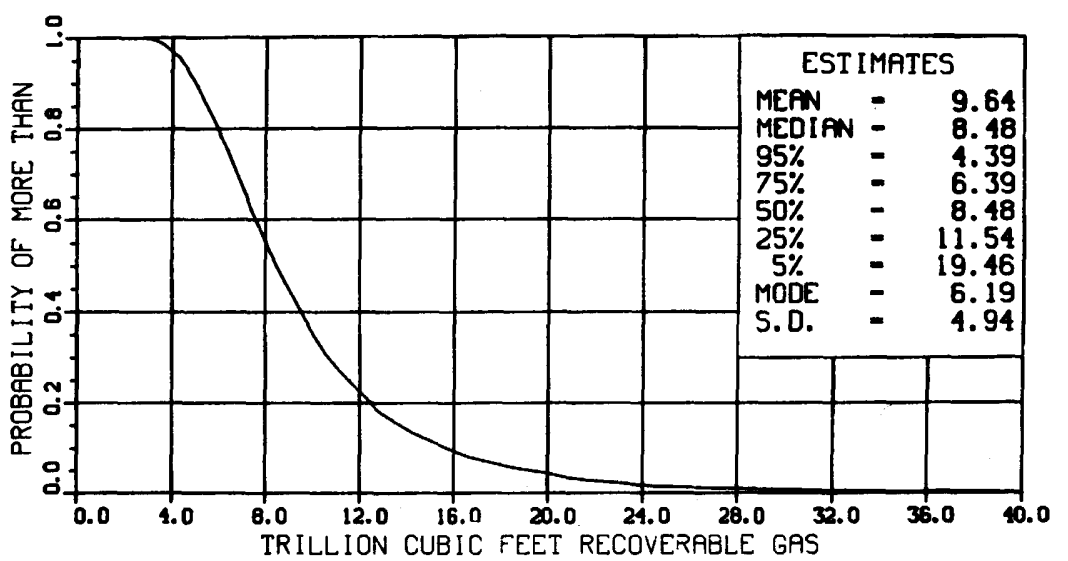

Region 2.--Pacific Coast 
OIL

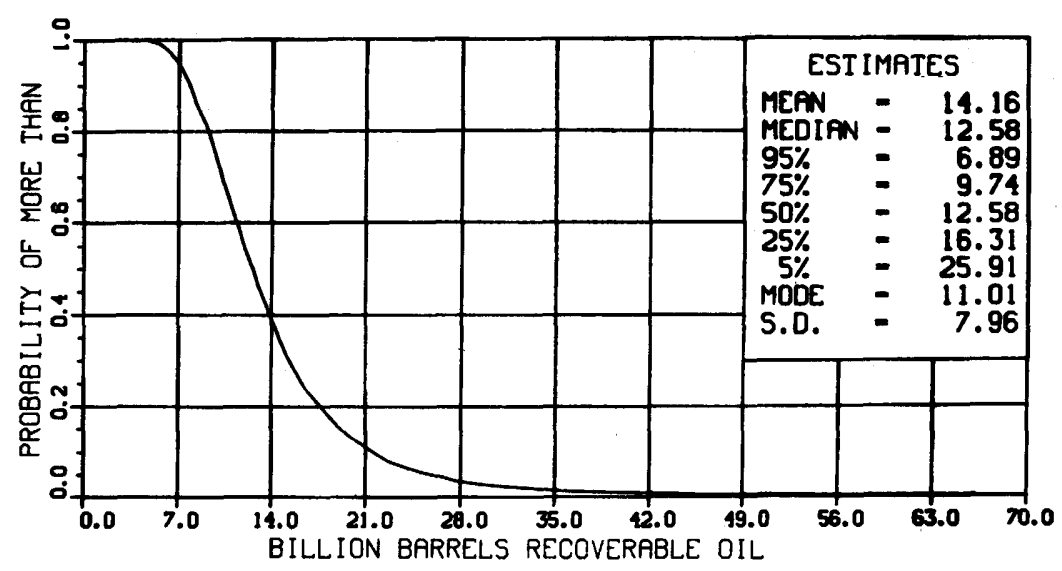

\& ASSOCIATED-DISSOLVED GAS

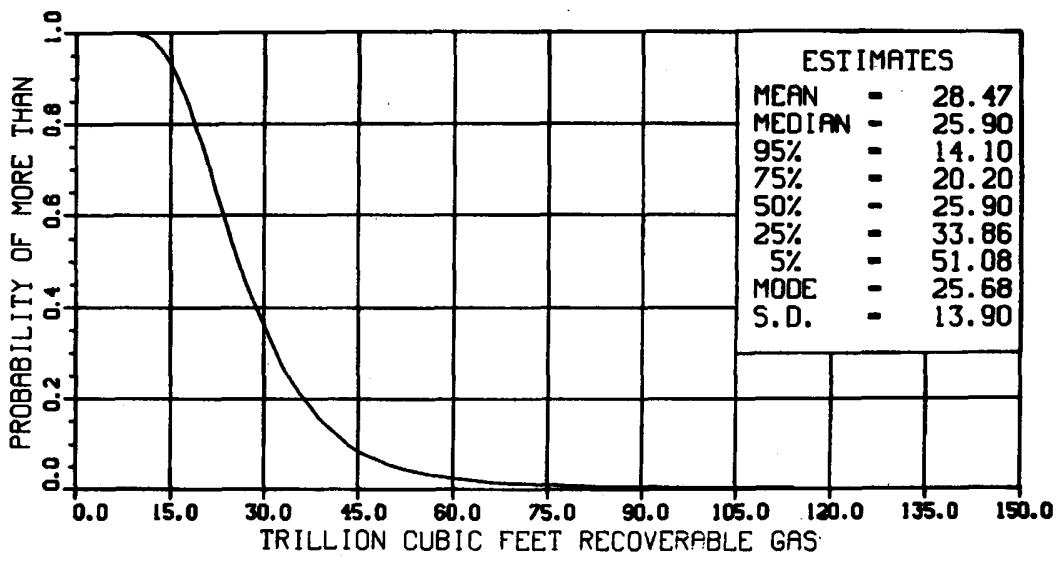

TOTAL GAS

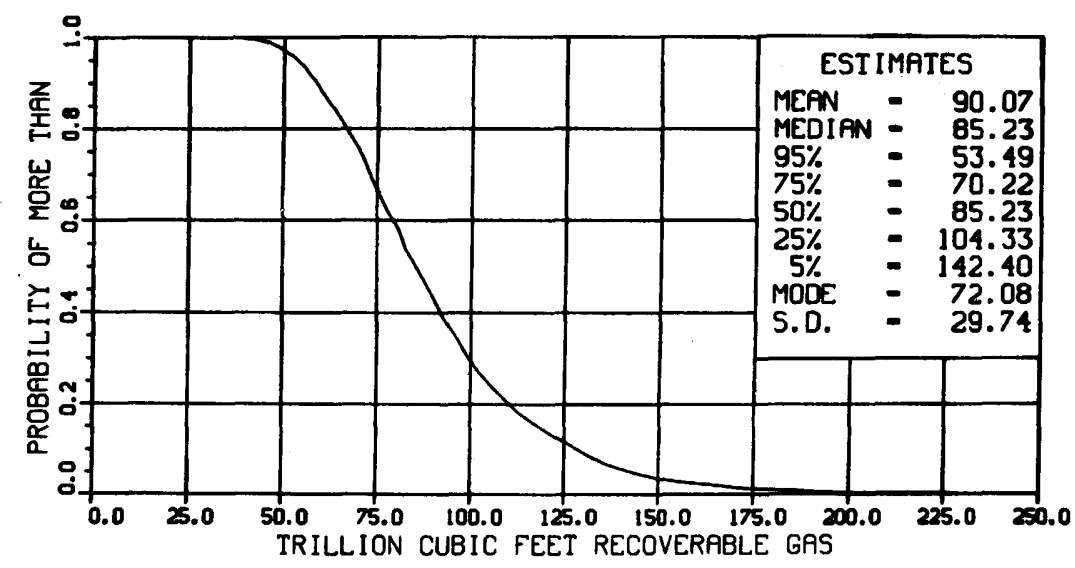

NON-ASSOCIATED GAS

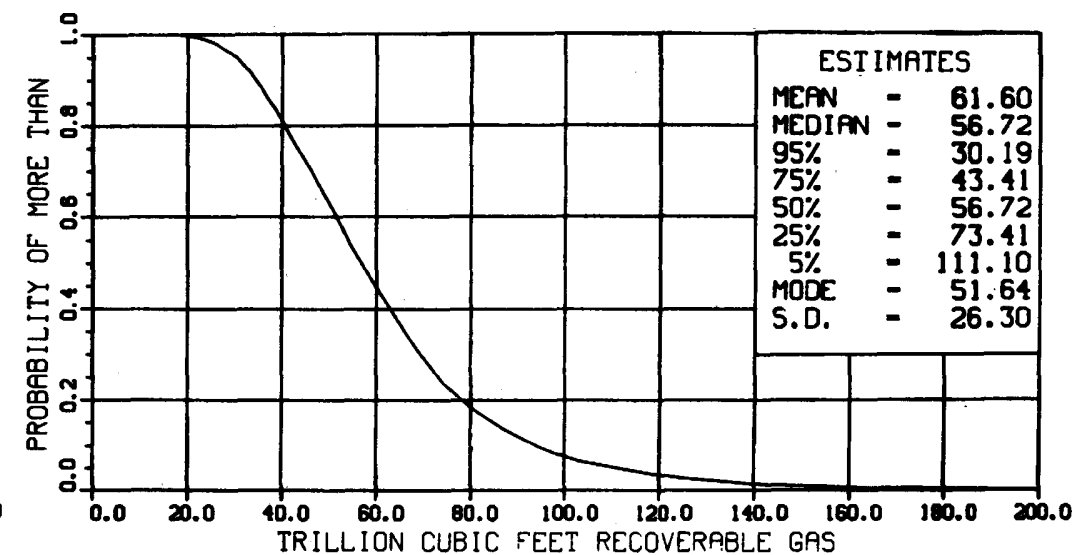

Region 3.--Colorado Plateau and Basin and Range 
OIL

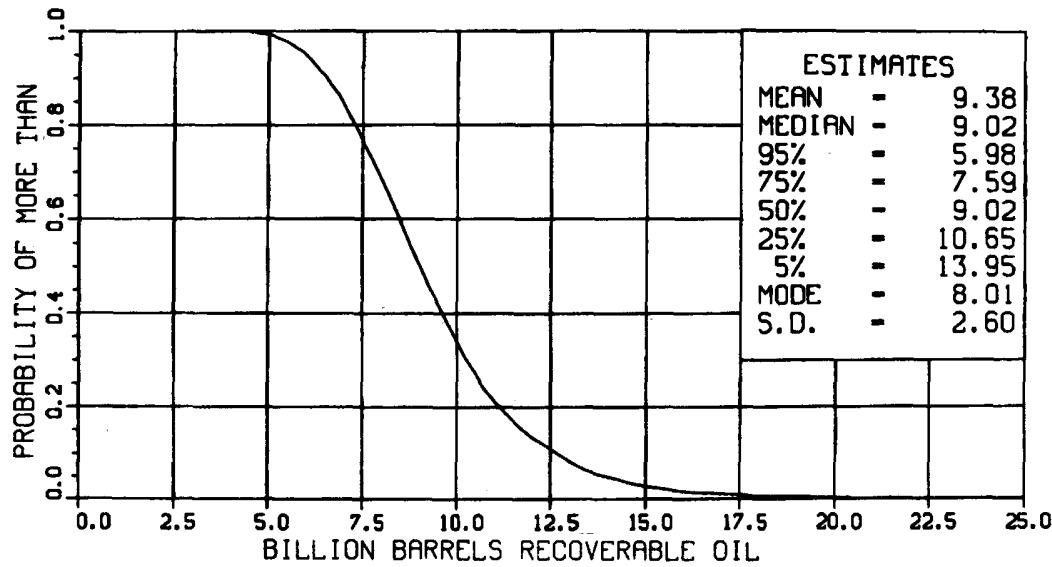

A ASSOCIATED-DISSOLVED GAS

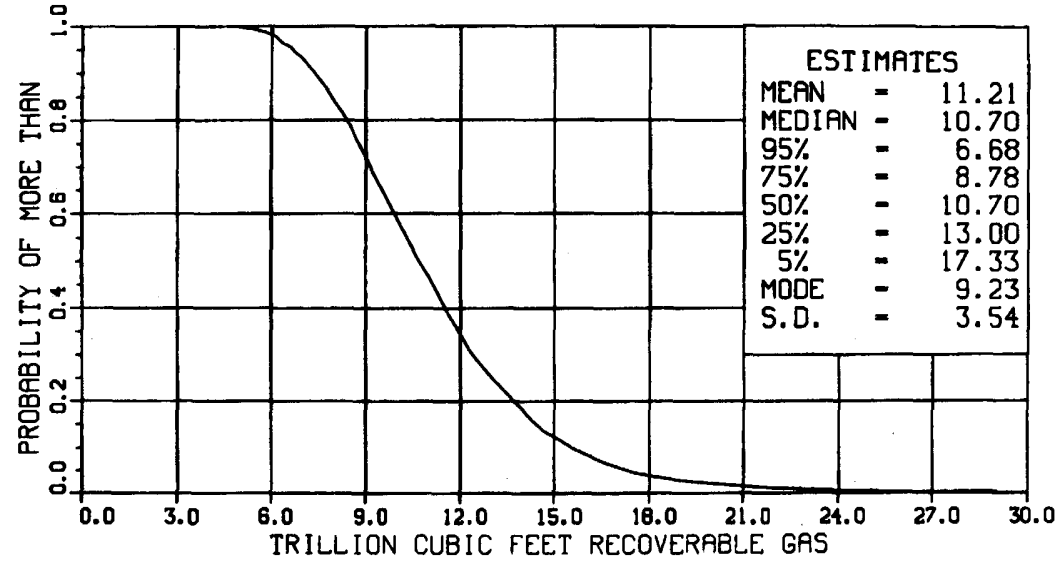

TOTAL GAS

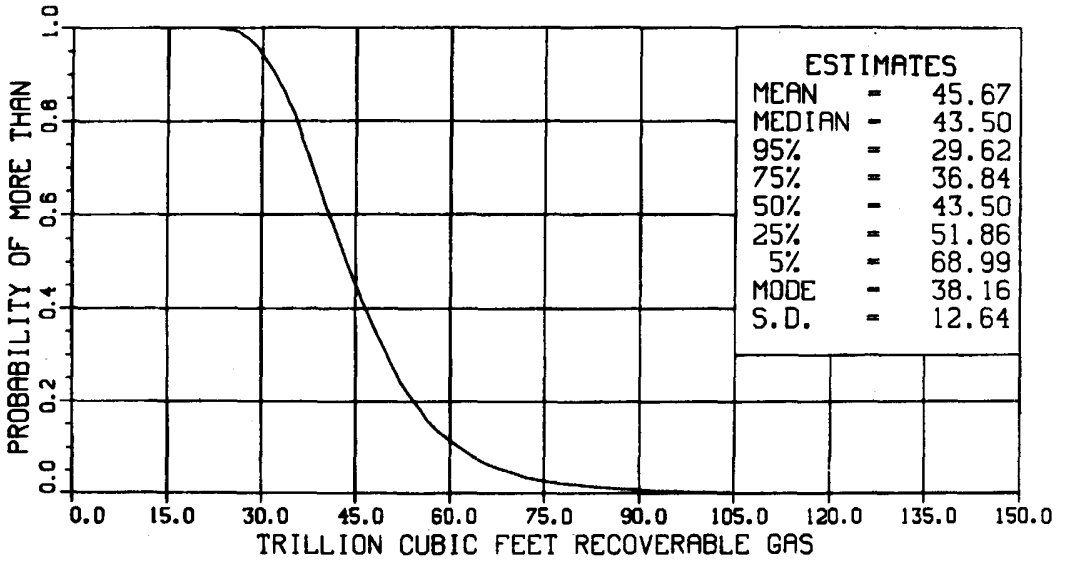

NON-ASSOCIATED GAS

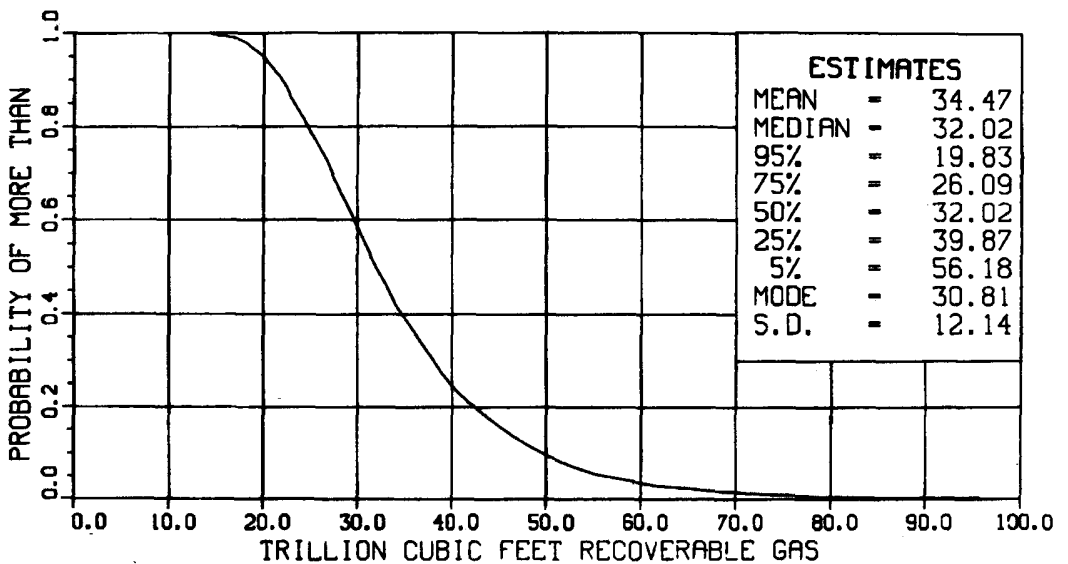

Region 4.--Rocky Mountains and Northern Great Plains 
OIL

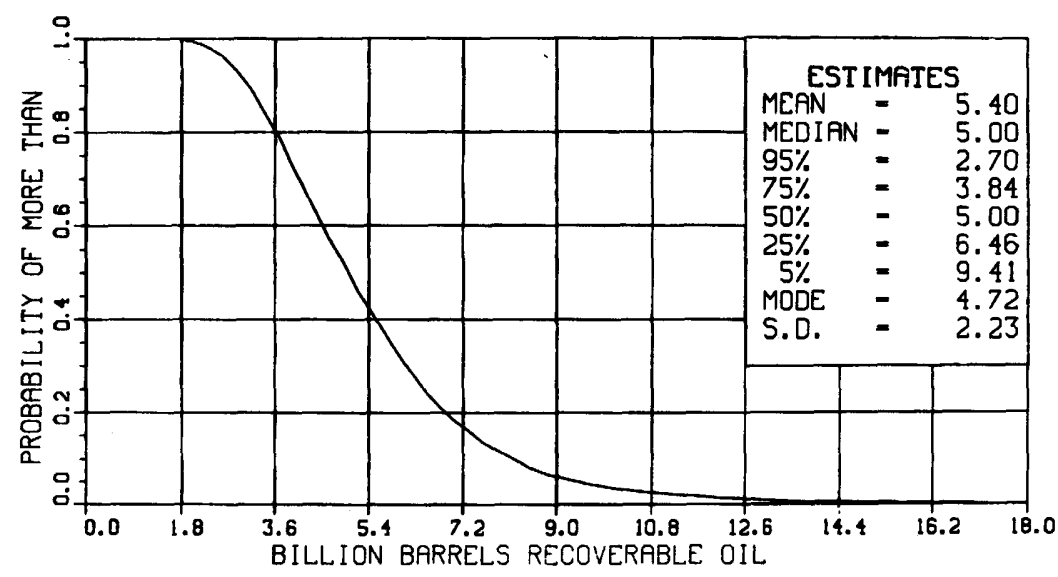

$\stackrel{\infty}{\infty}$ ASSOCIATED-DISSOLVED GAS

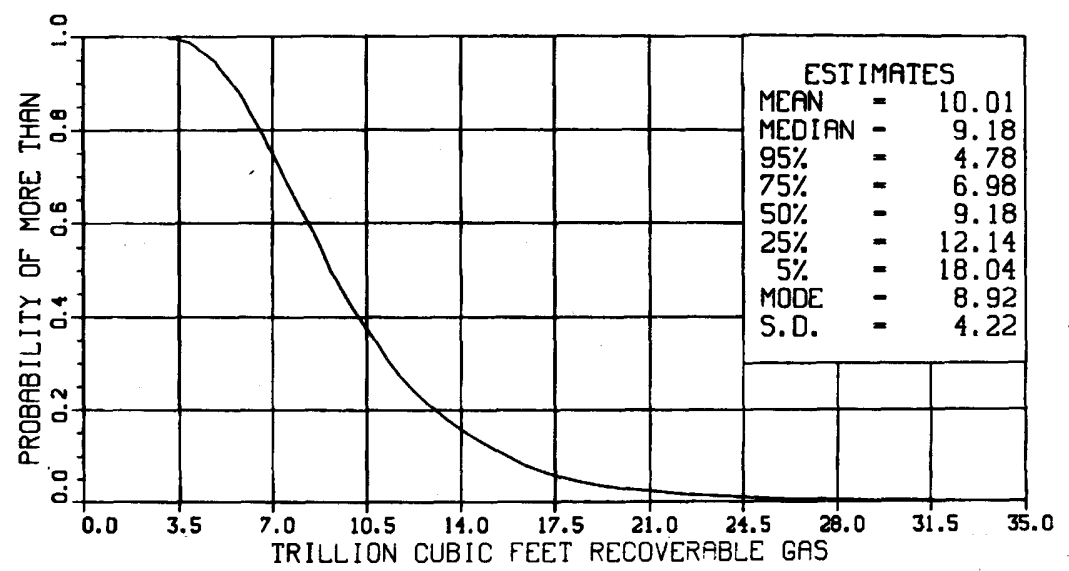

TOTAL GAS

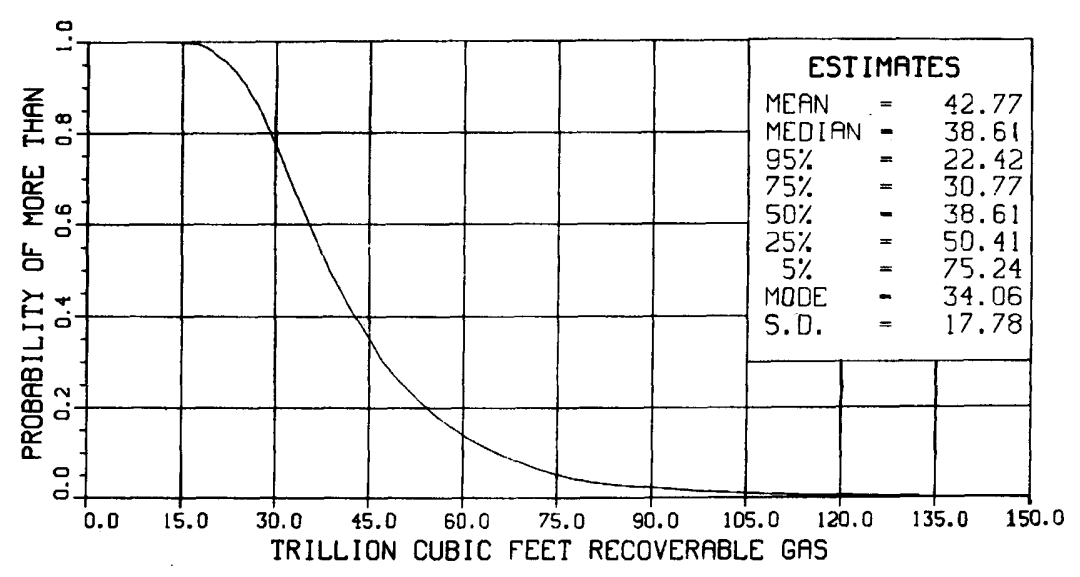

NON-ASSOCIATED GAS

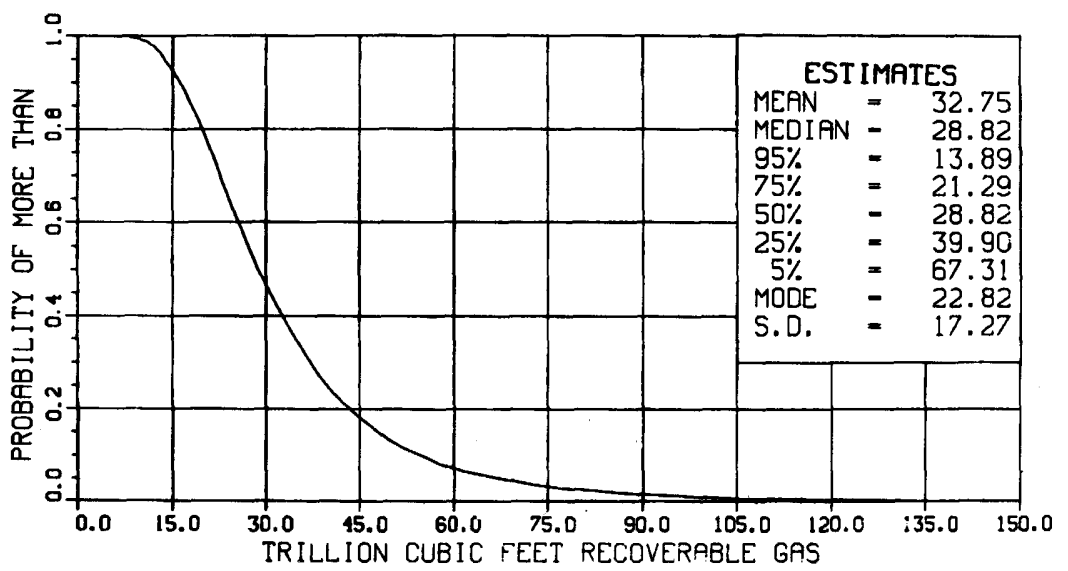

Region 5.--West Texas and Eastern New Mexico 
OIL

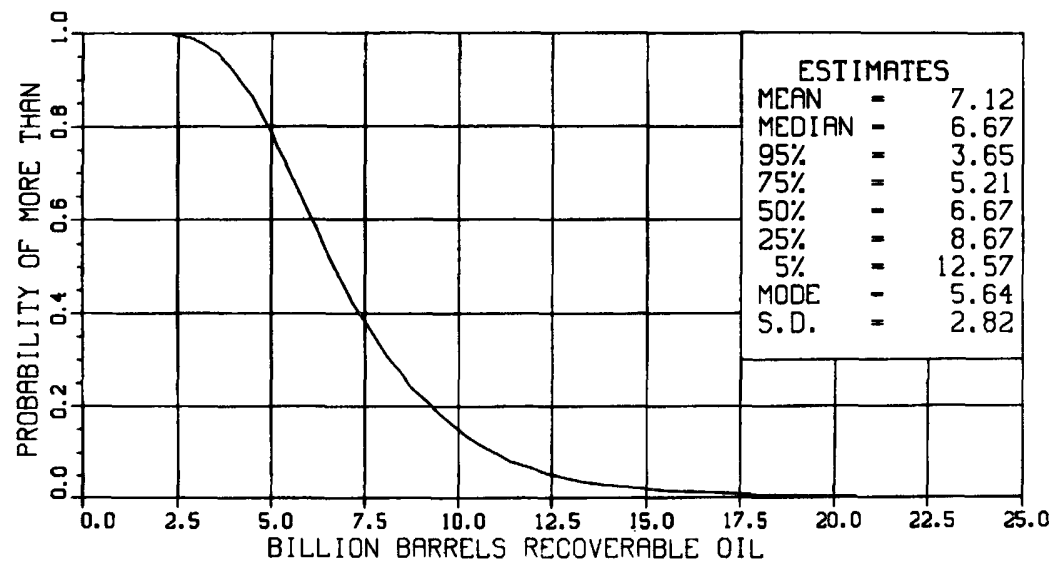

号 ASSOCIATED-DISSOLVED GAS

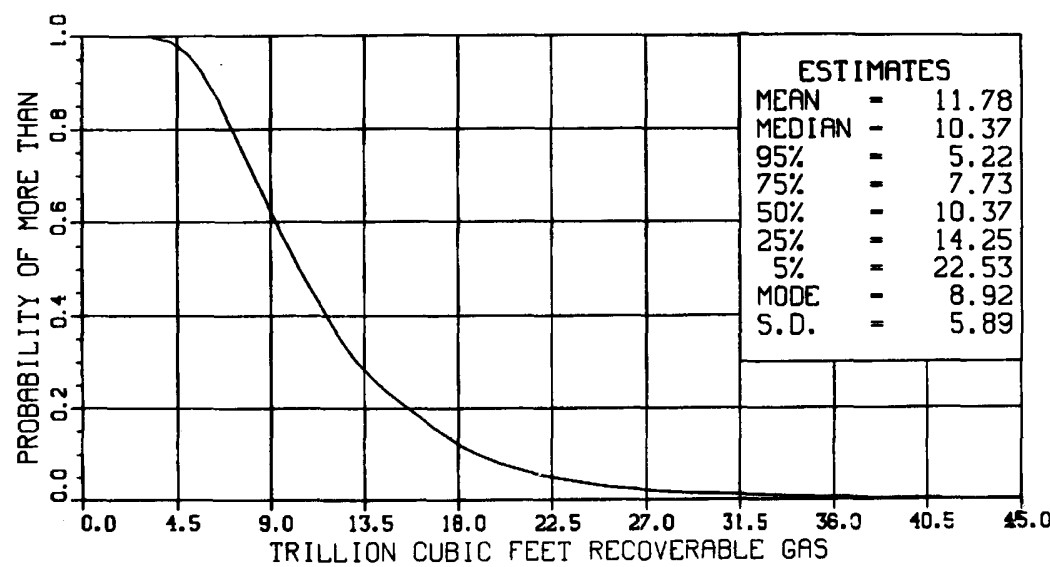

TOTAL GAS

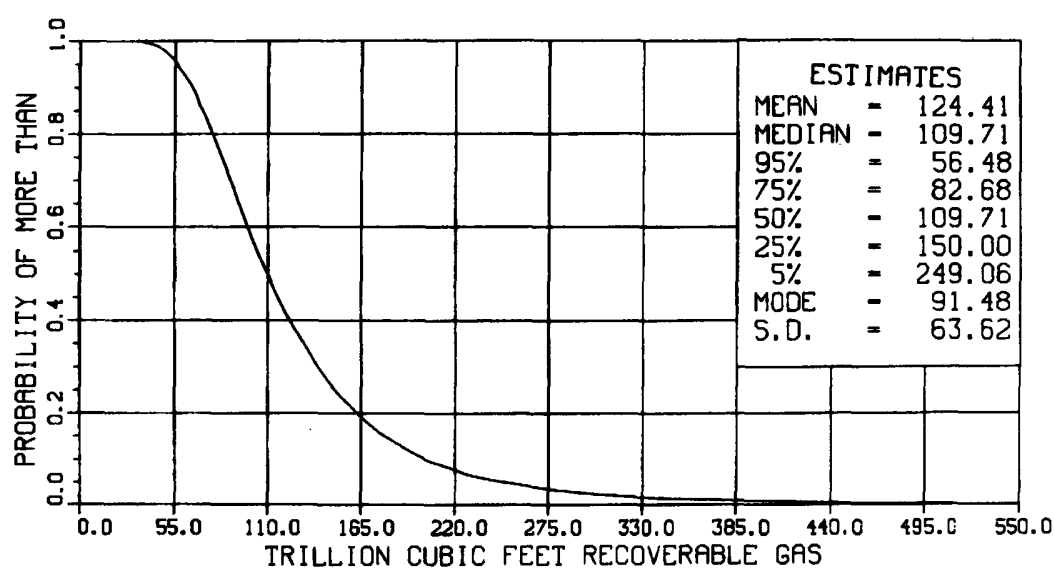

NON-ASSOCIATED GAS

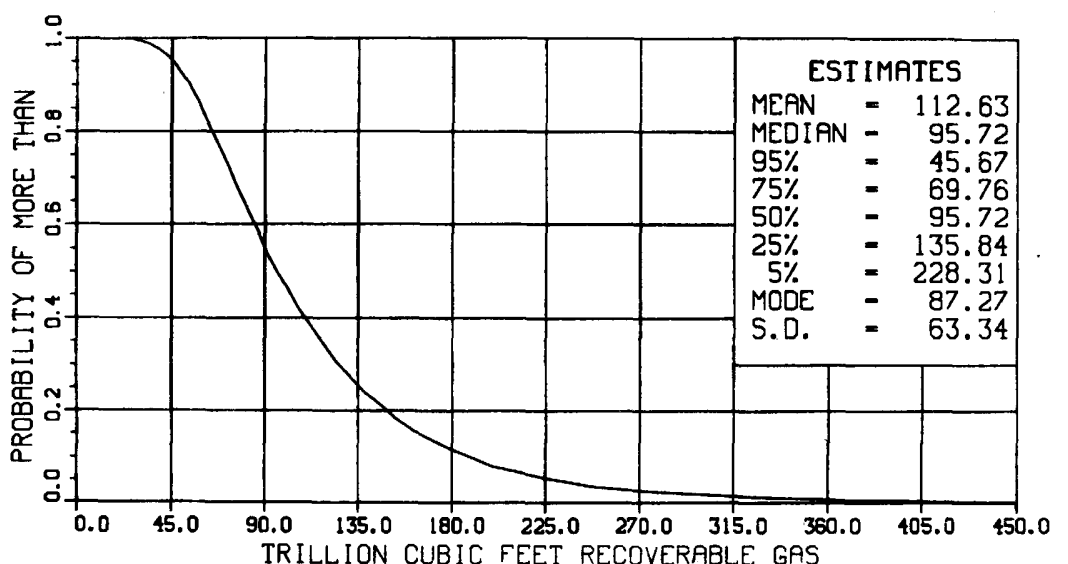

Region 6.--Gulf Coast 
OIL

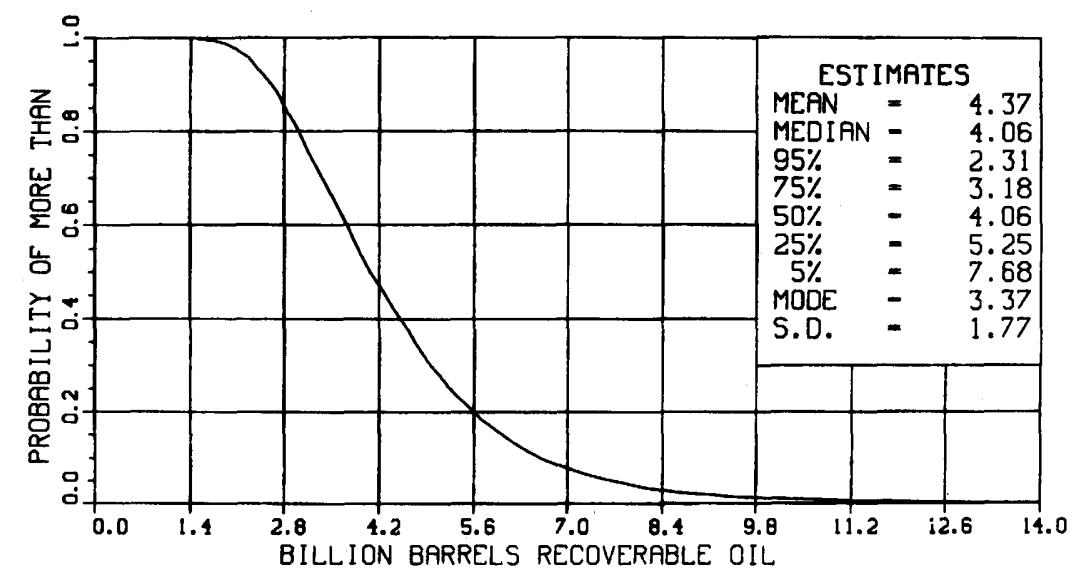

n

GIATED-DISSOLVED GAS

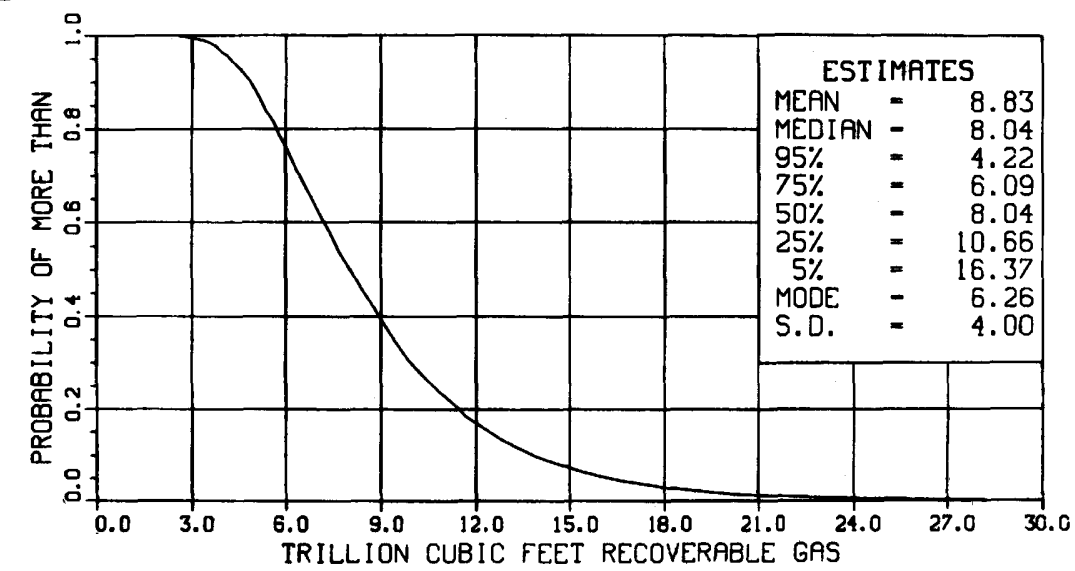

TOTAL GAS

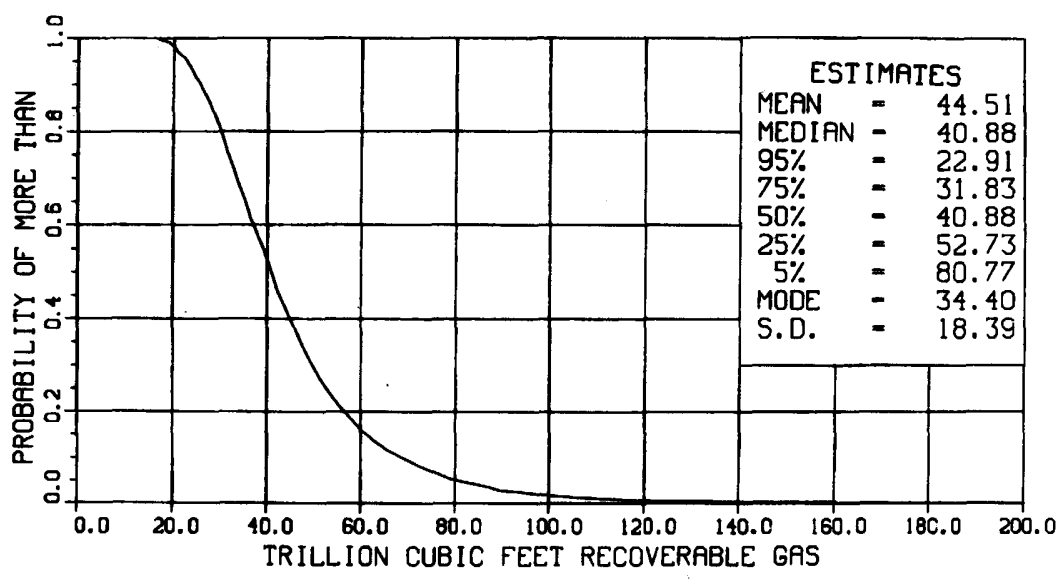

NON-ASSOCIATED GAS

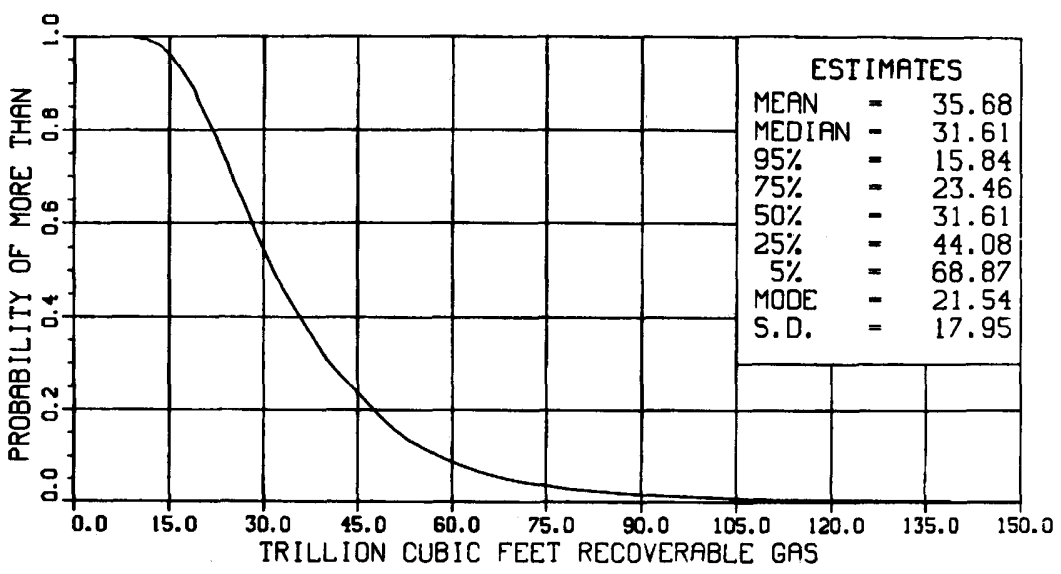

Region 7.--Mid-continent 
OIL

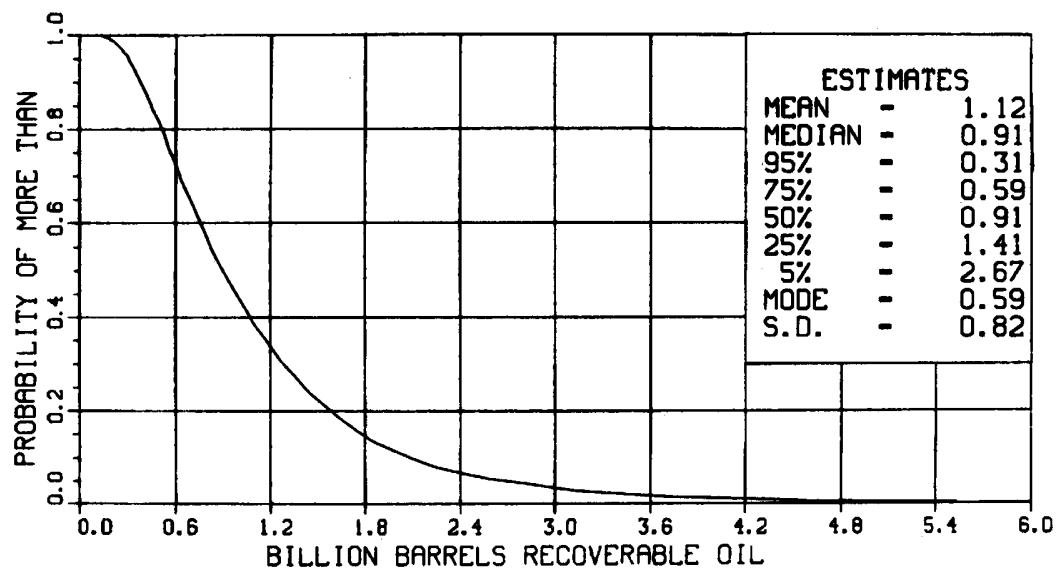

$\cong$ ASSOCIATED-DISSOLVED GAS

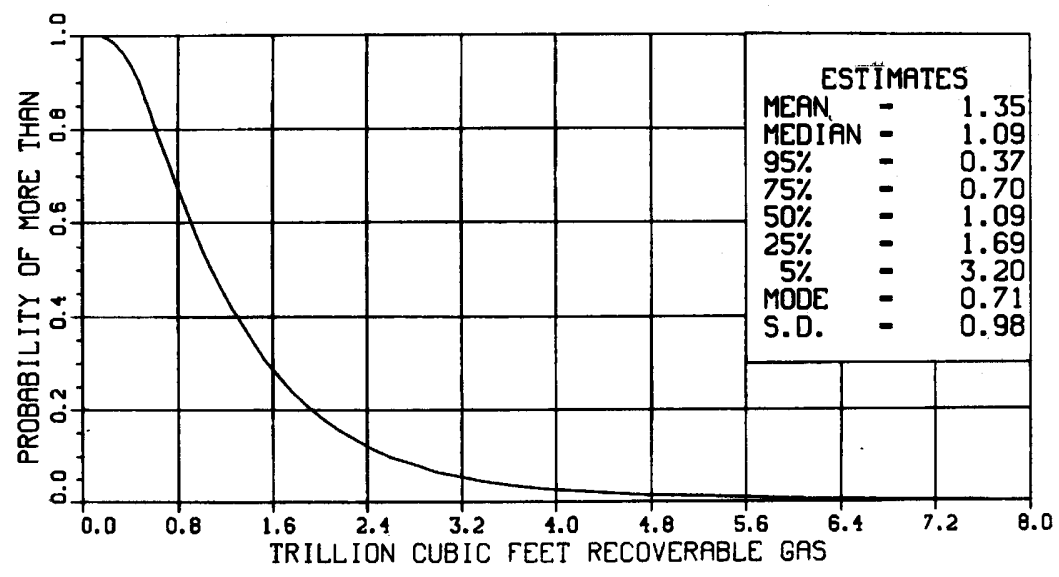

TOTAL GAS

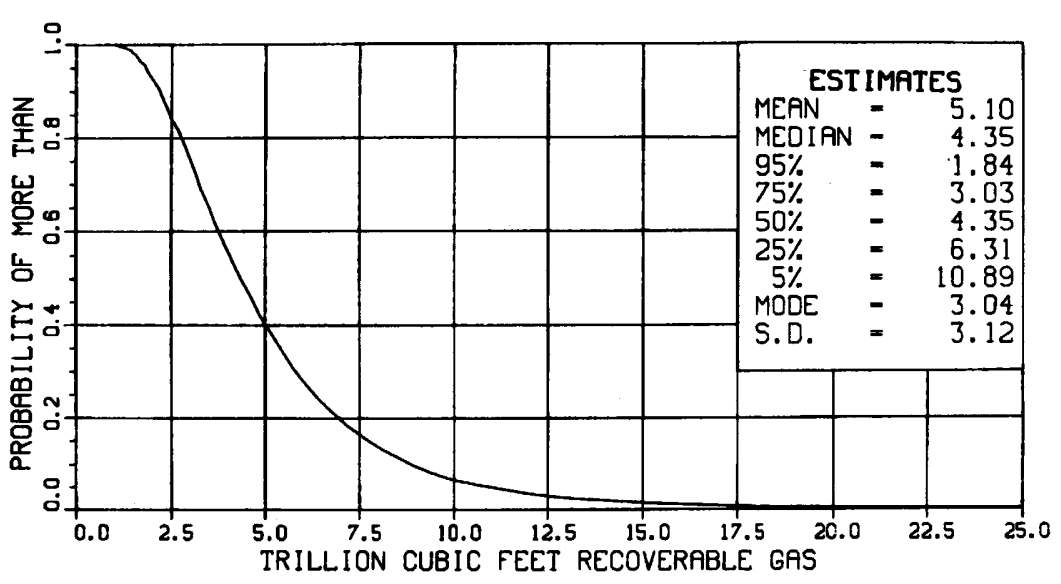

NON-ASSOCIATED GAS

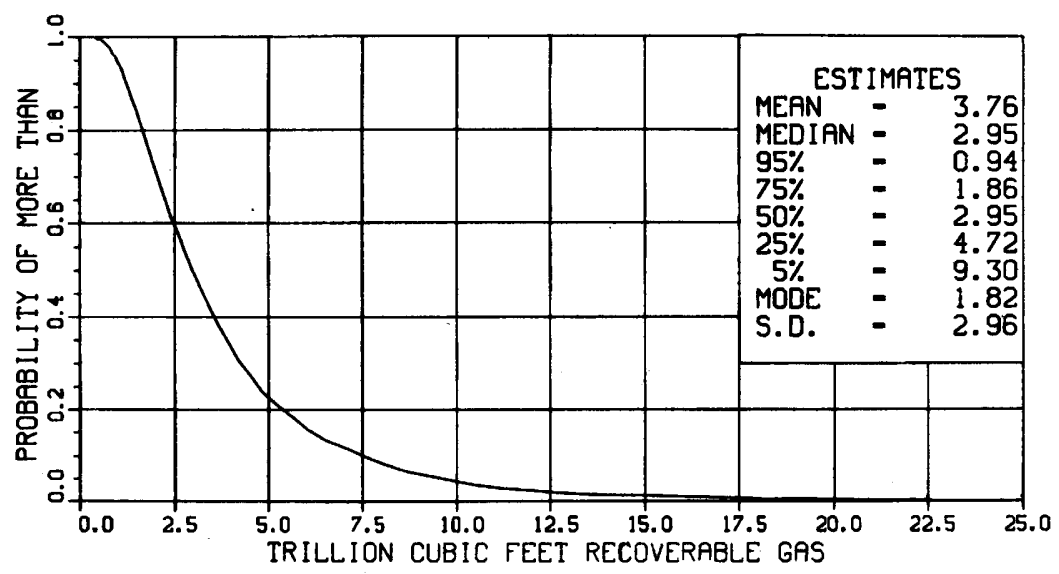

Region 8.--Michigan Basin 
OIL

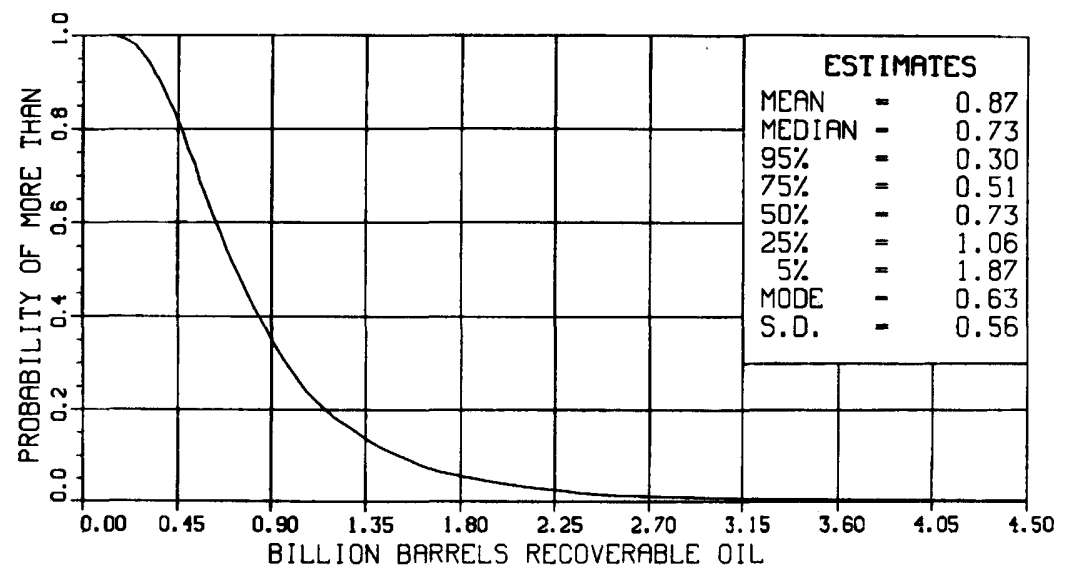

N ASSOCIATED-DISSOLVED GAS

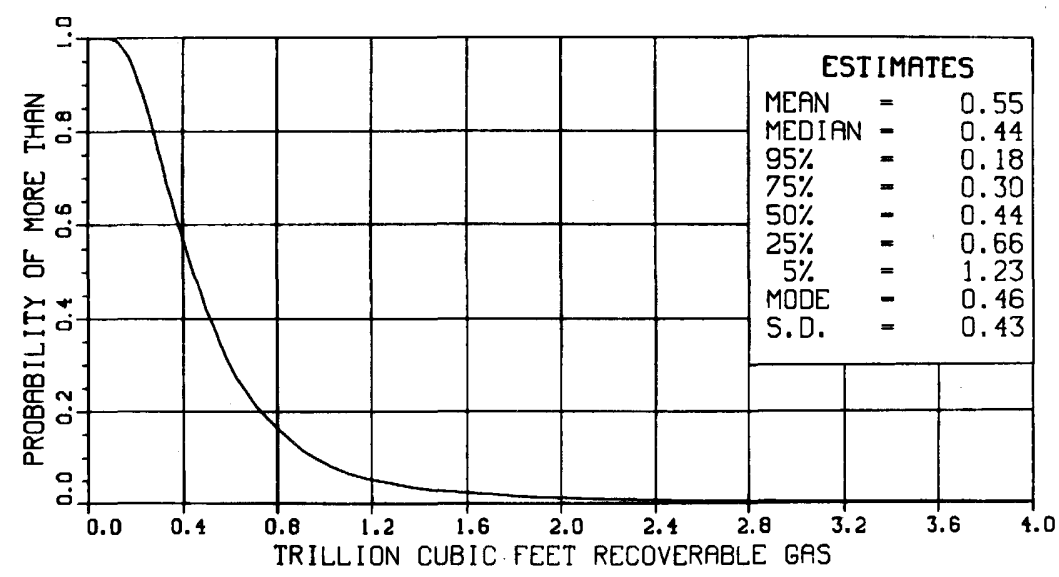

TOTAL GAS

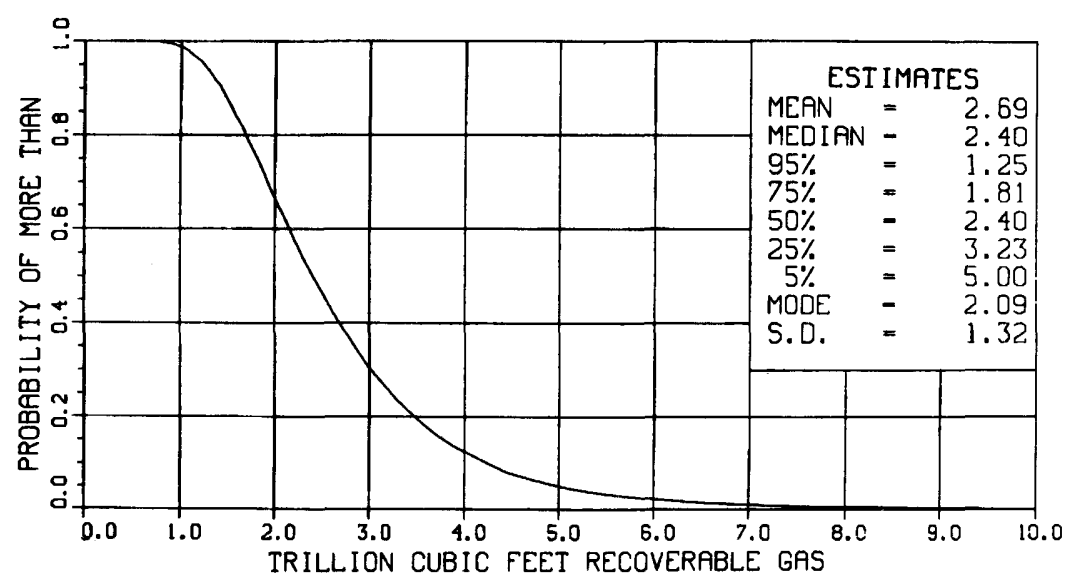

NON-ASSOCIATED GAS

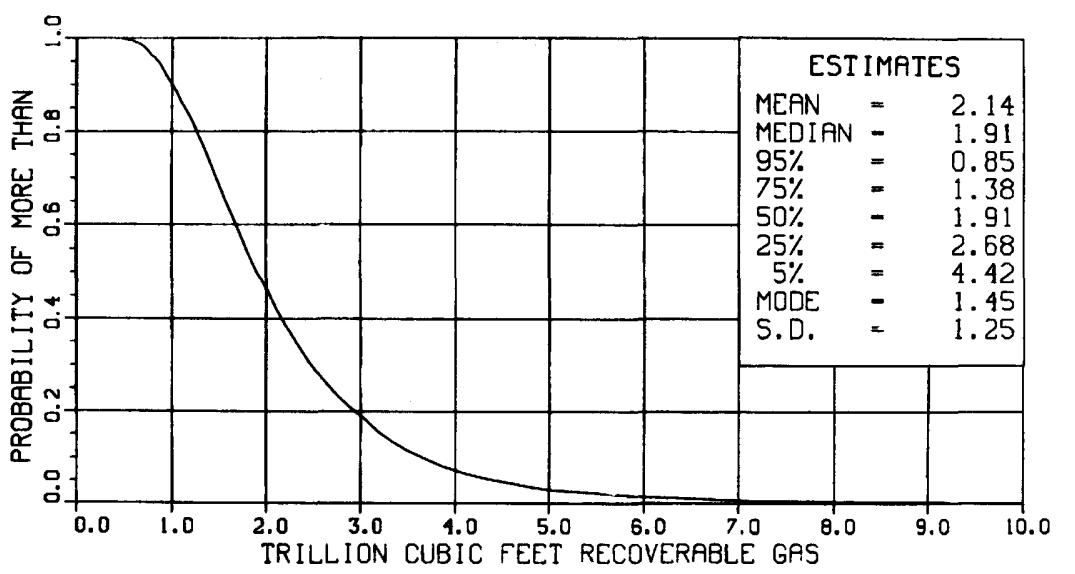

Region 9.--Eastern Interior 
OIL

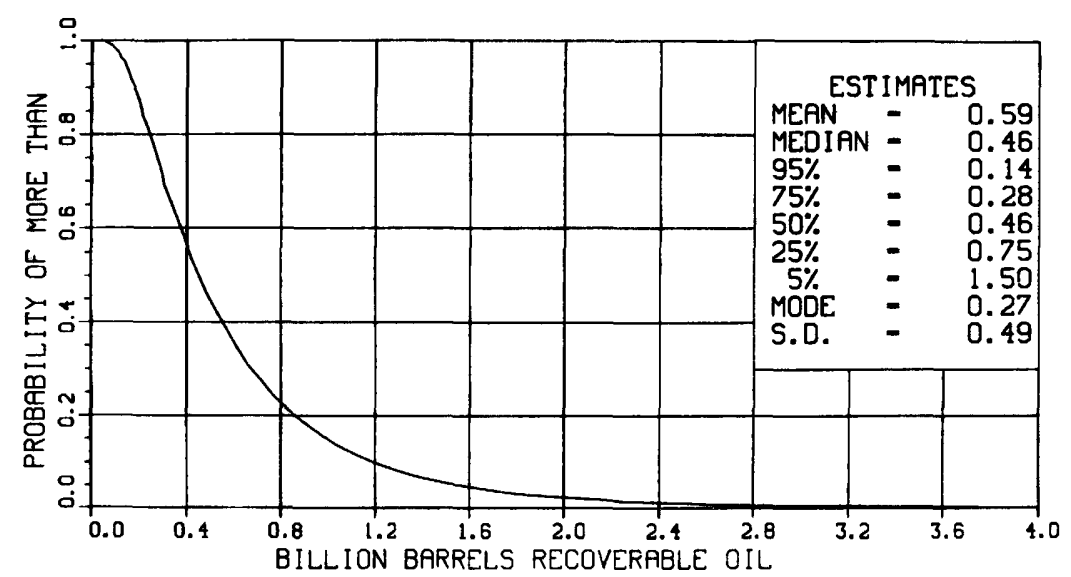

u ASSOCIATED-DISSOLVED GAS

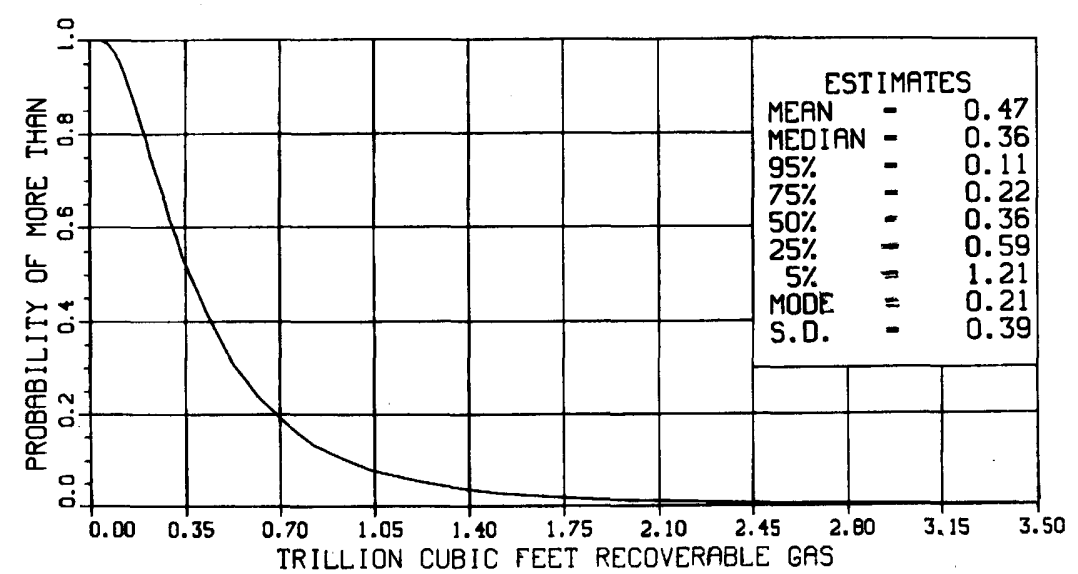

TOTAL GAS

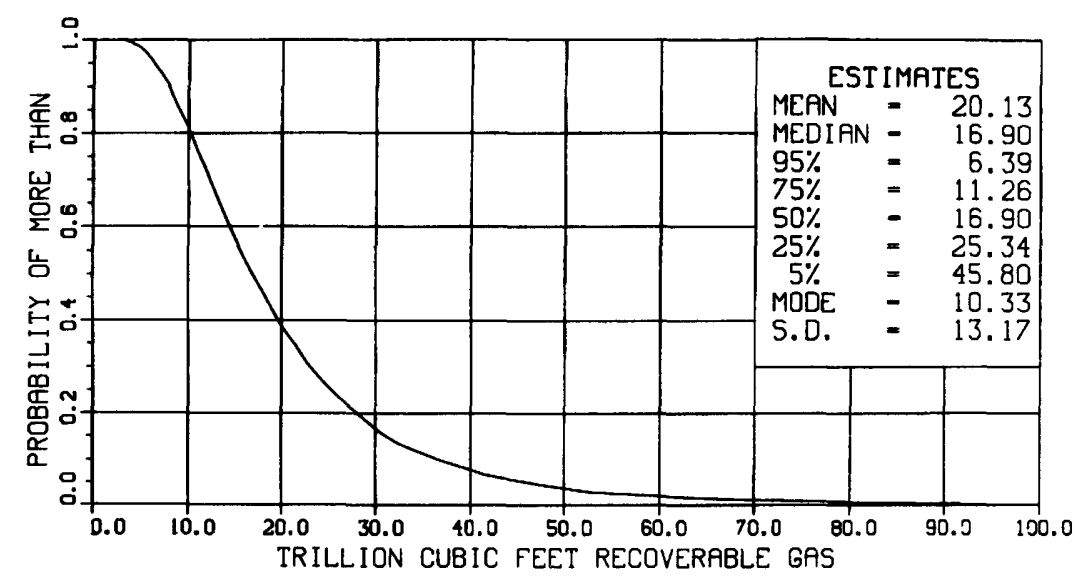

NON-ASSOCIATED GAS

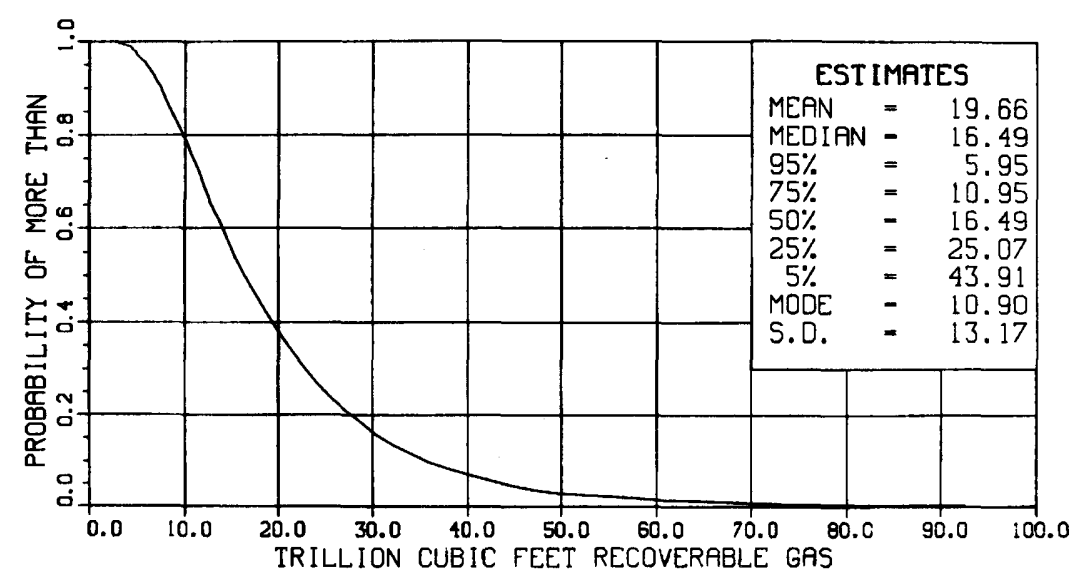

Region 10.--Appalachians 
OIL

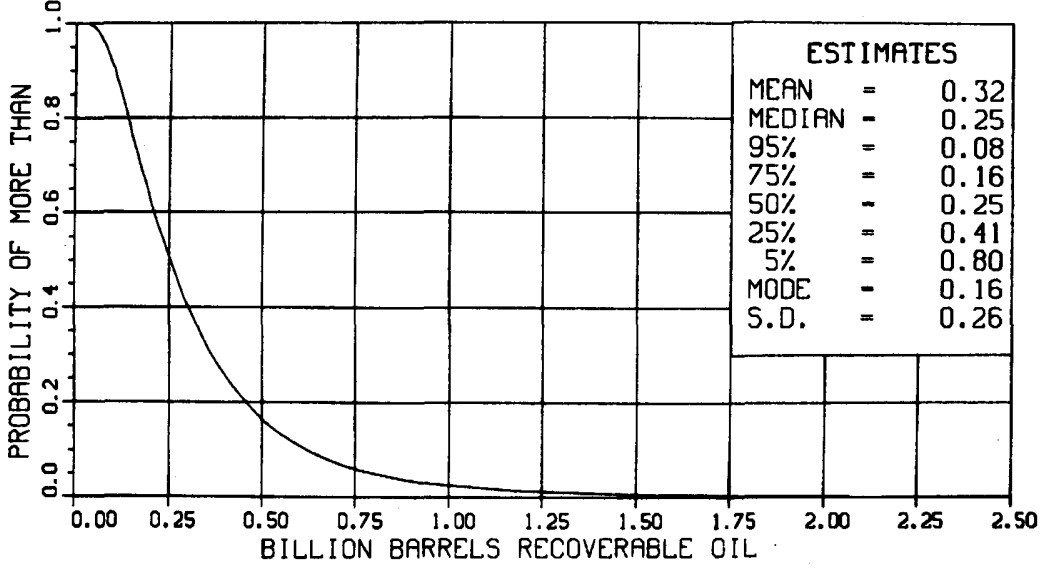

M

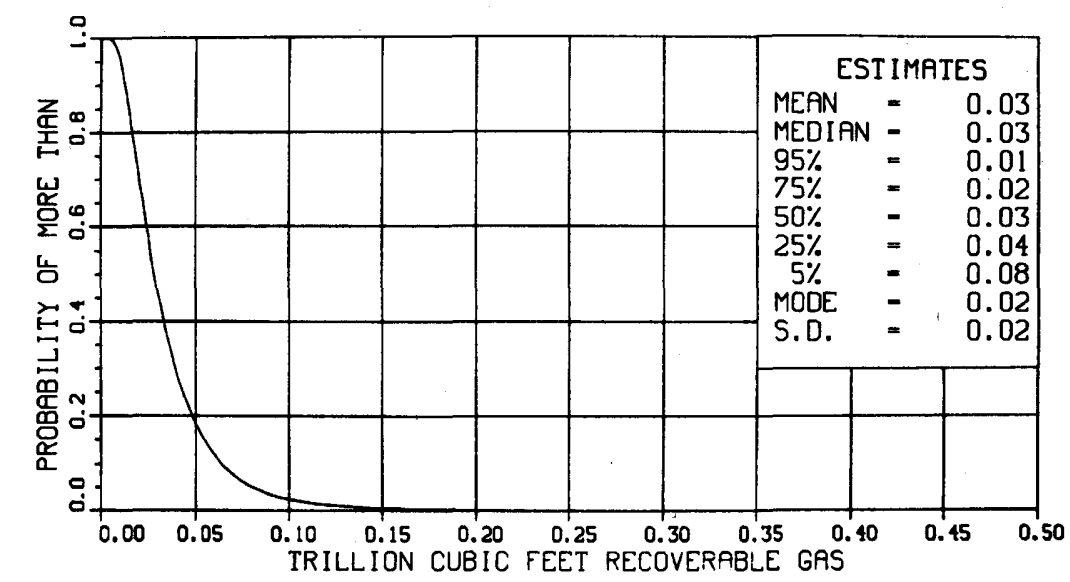

TOTAL GAS

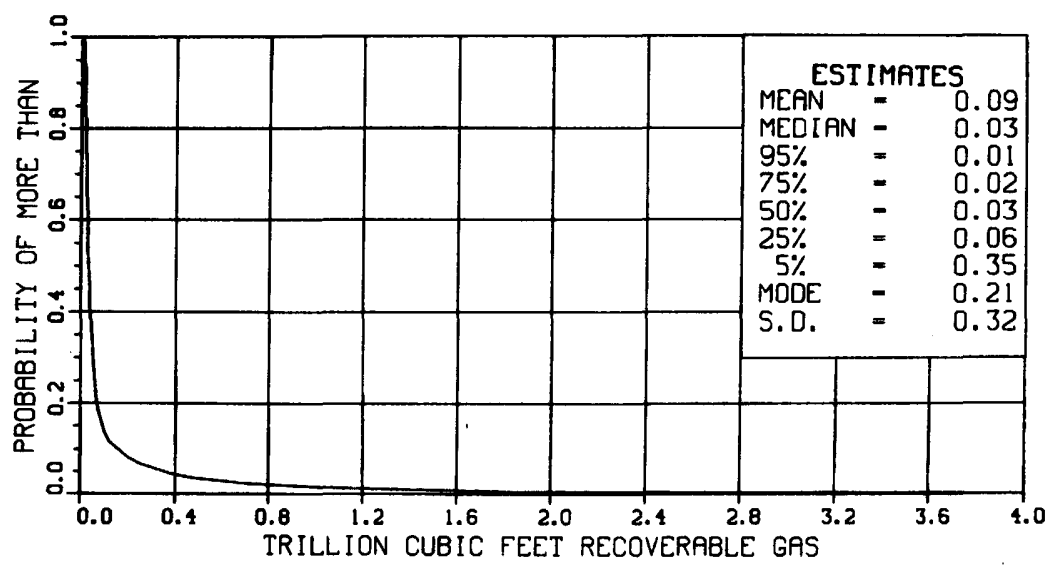

NON-ASSOCIATED GAS

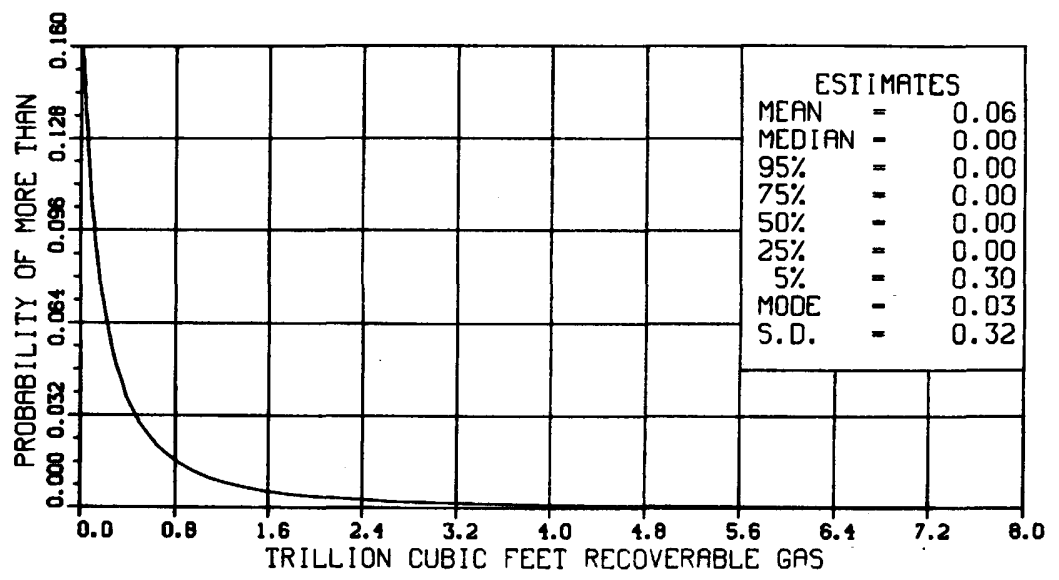

Region 11.--Atlantic Coast 
OIL

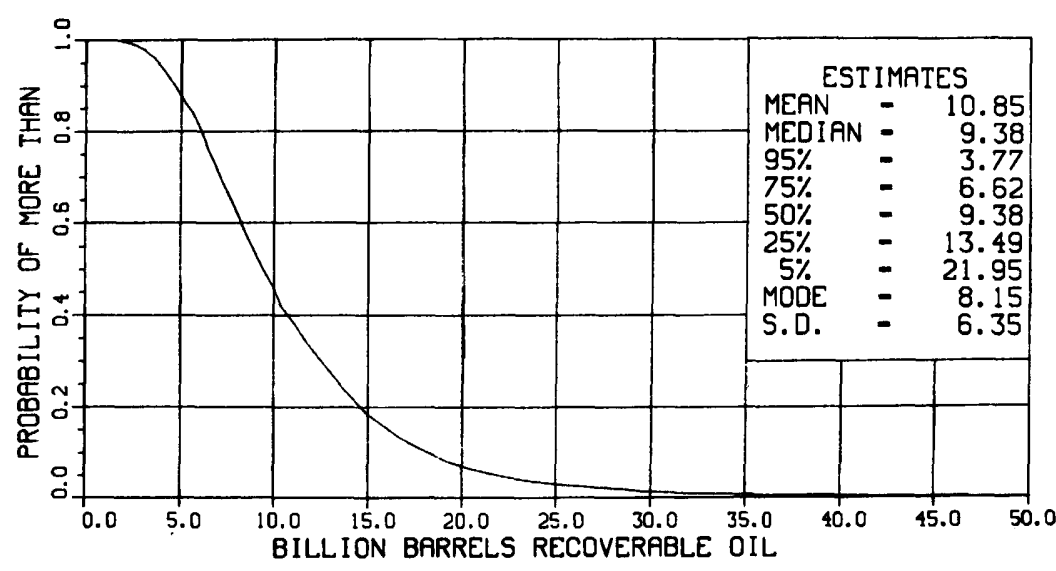

UI ASSOCIATED-DISSOLVED GAS

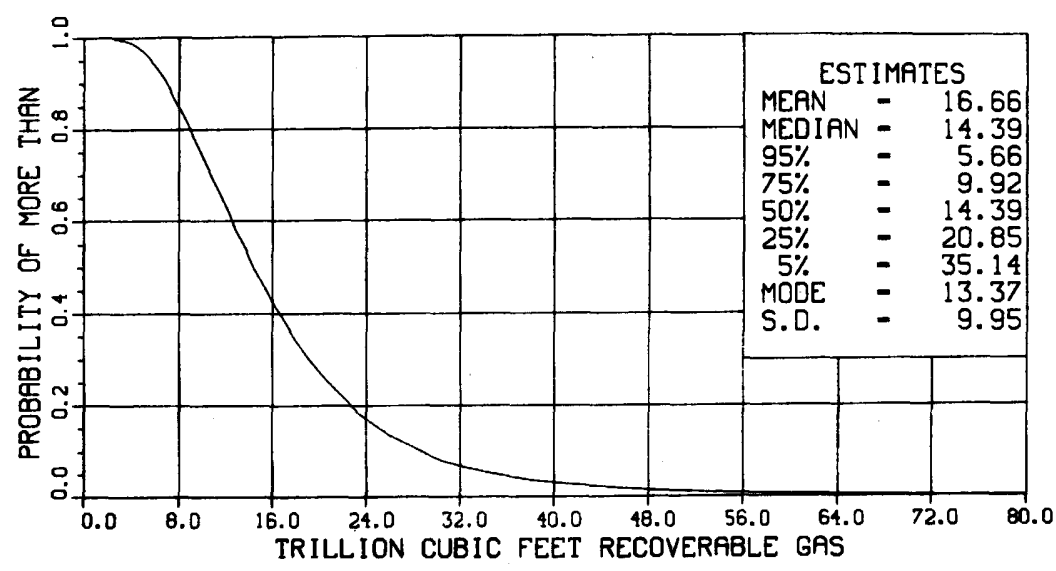

\section{TOTAL GAS}

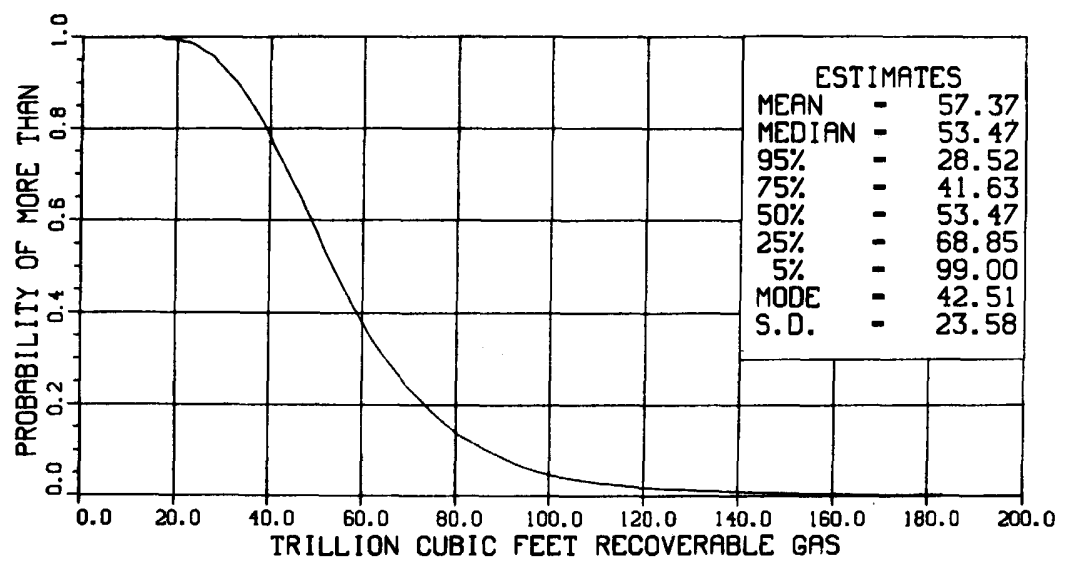

NON-ASSOCIATED GAS

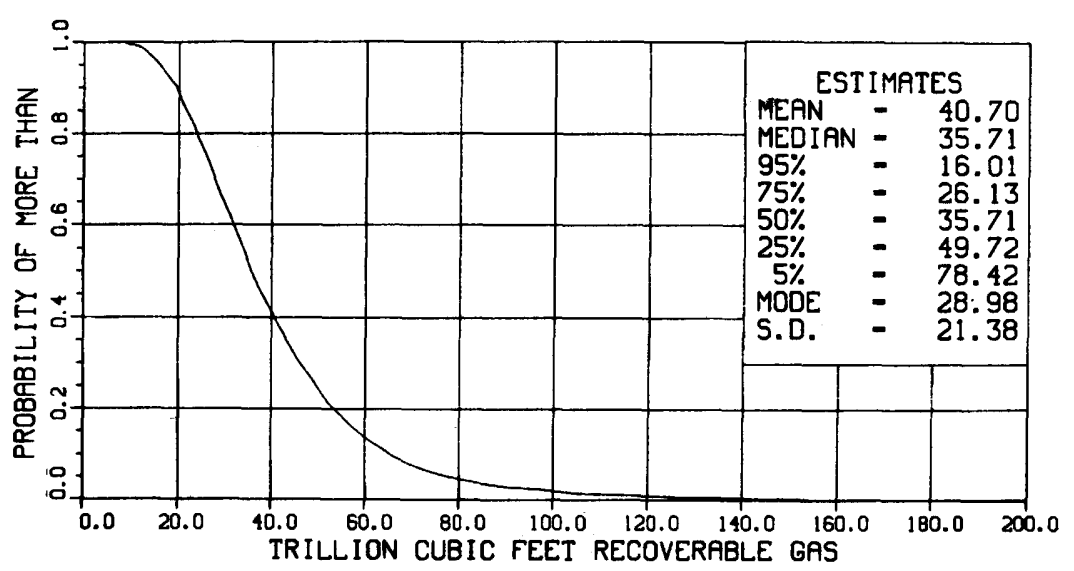

Region 1A.--Alaska shelf 

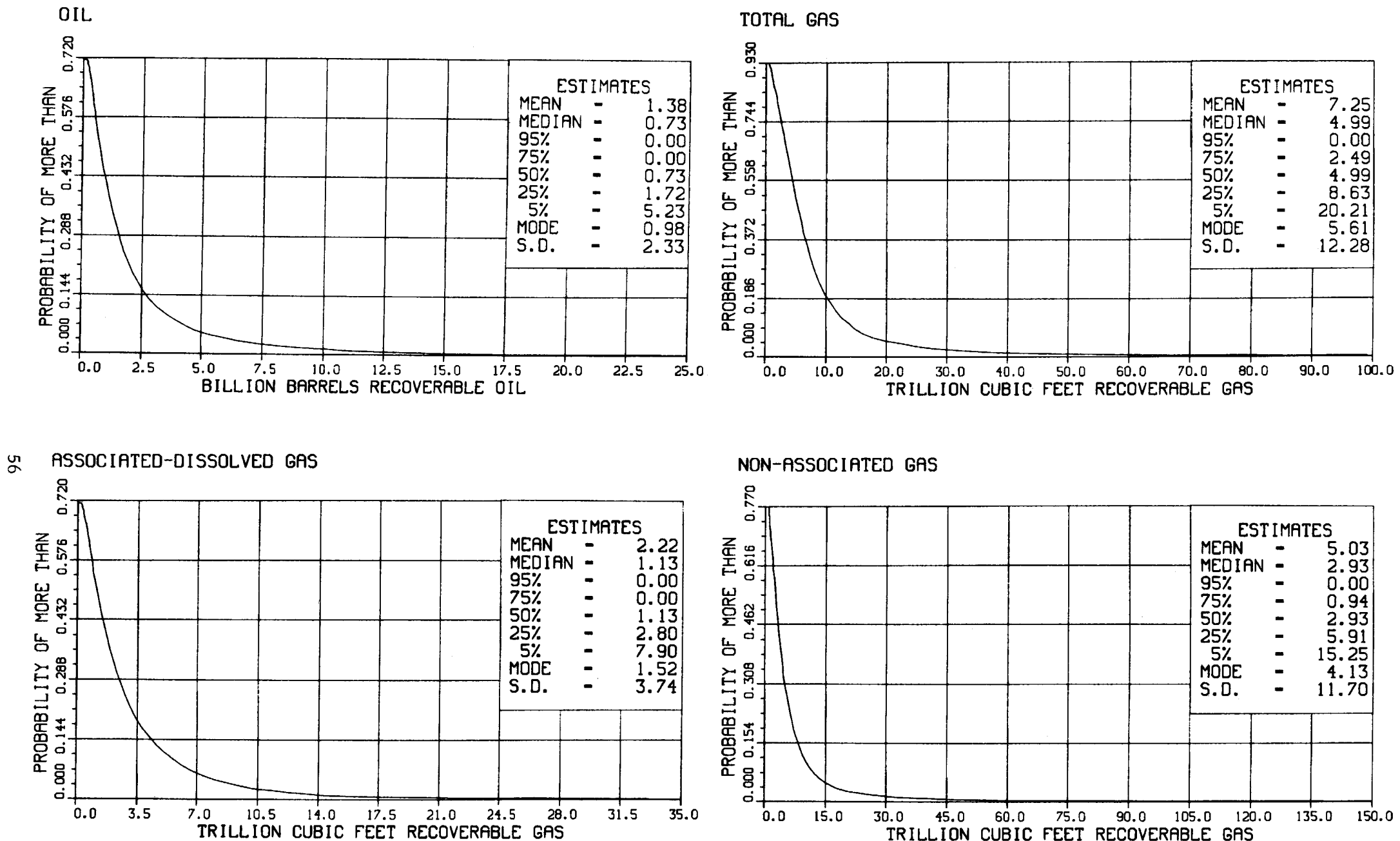

Region 1A.--Alaska slope 
OIL

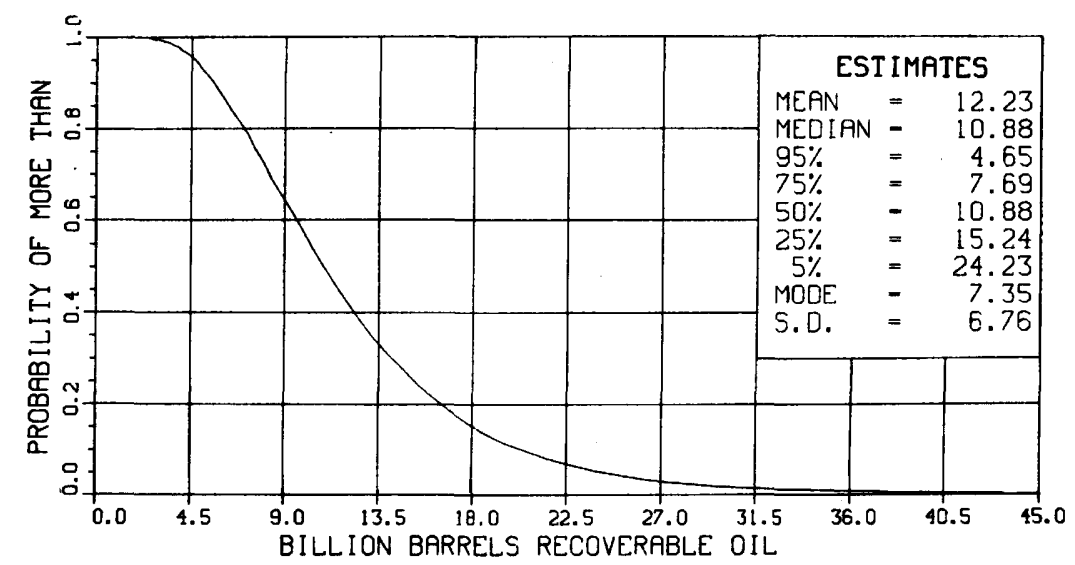

y RSSOCIATED-DISSOLVED GAS

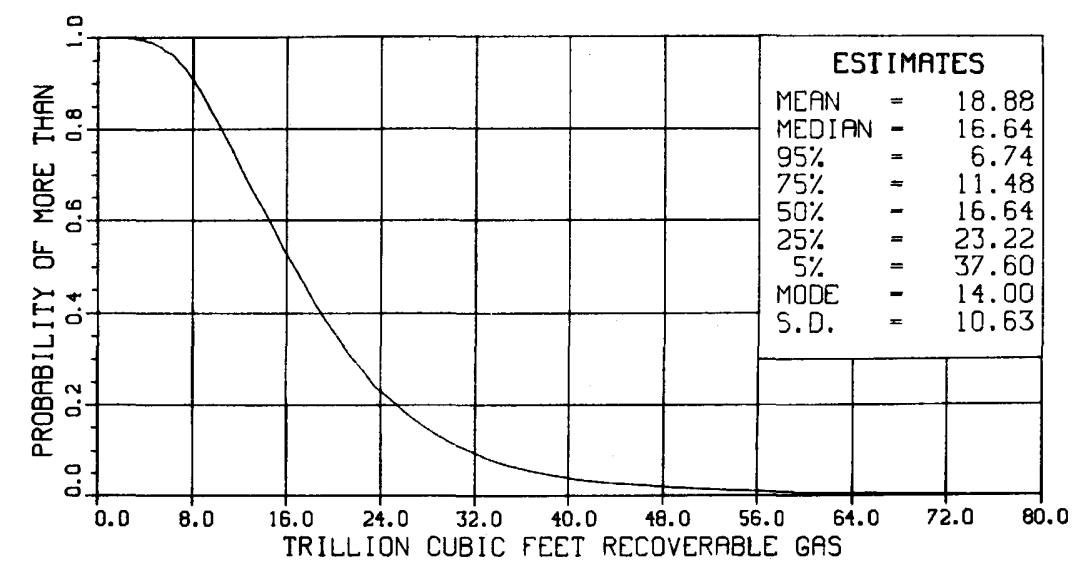

TOTAL GAS

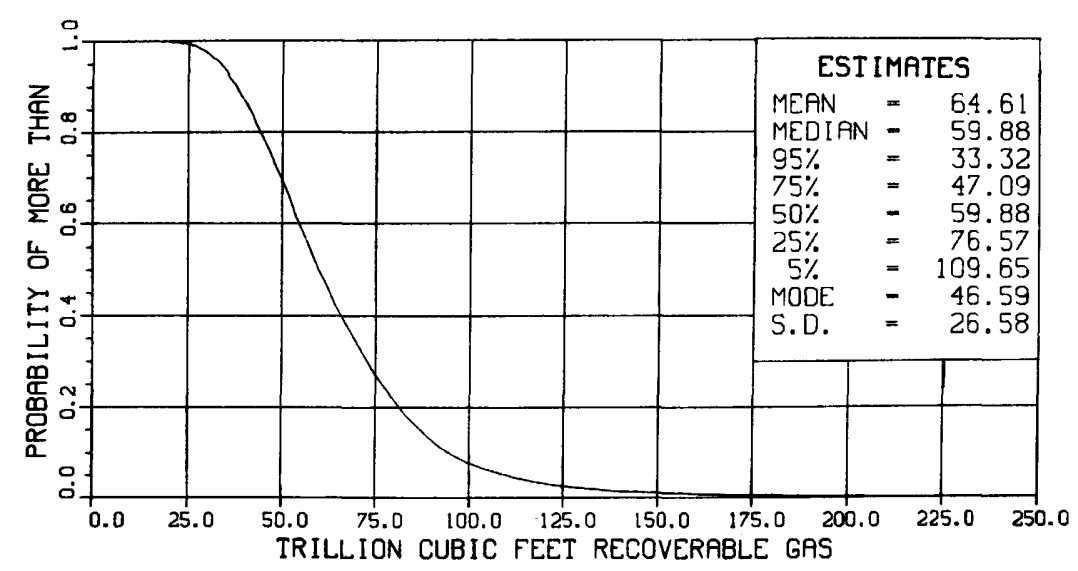

NON-ASSOCIATED GAS

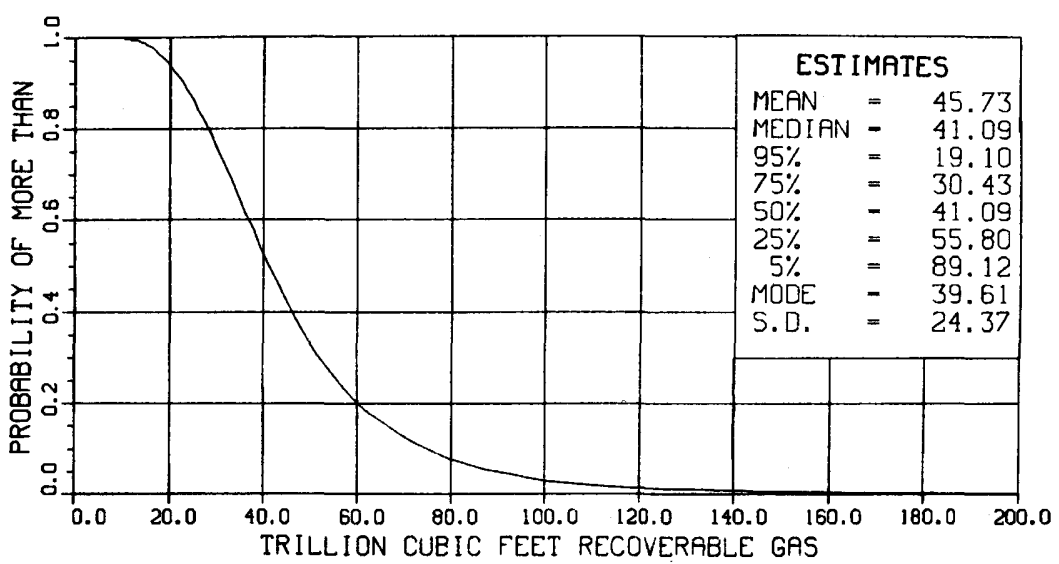

Region 1A.-Alaska entire offshore 
OIL

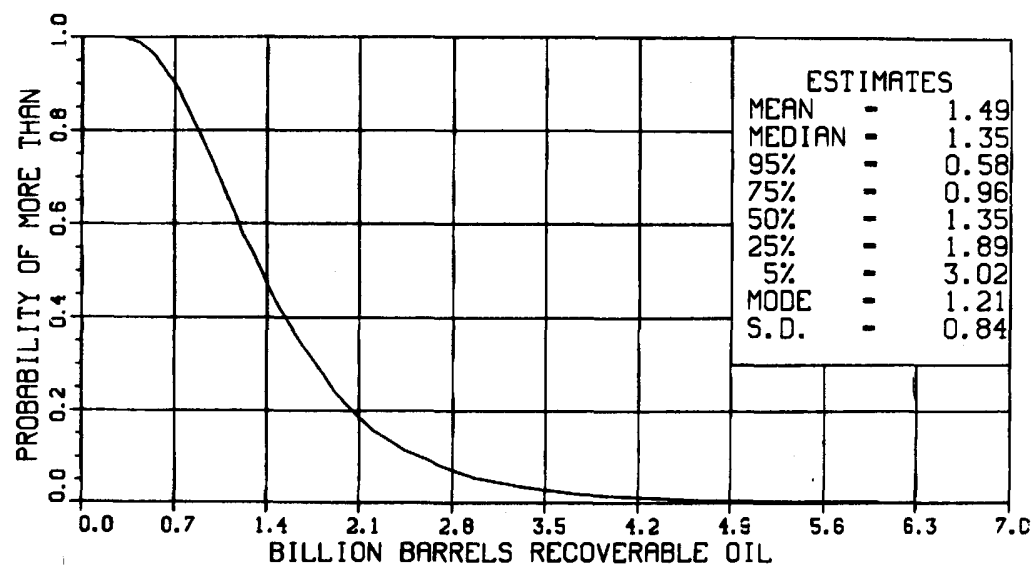

以

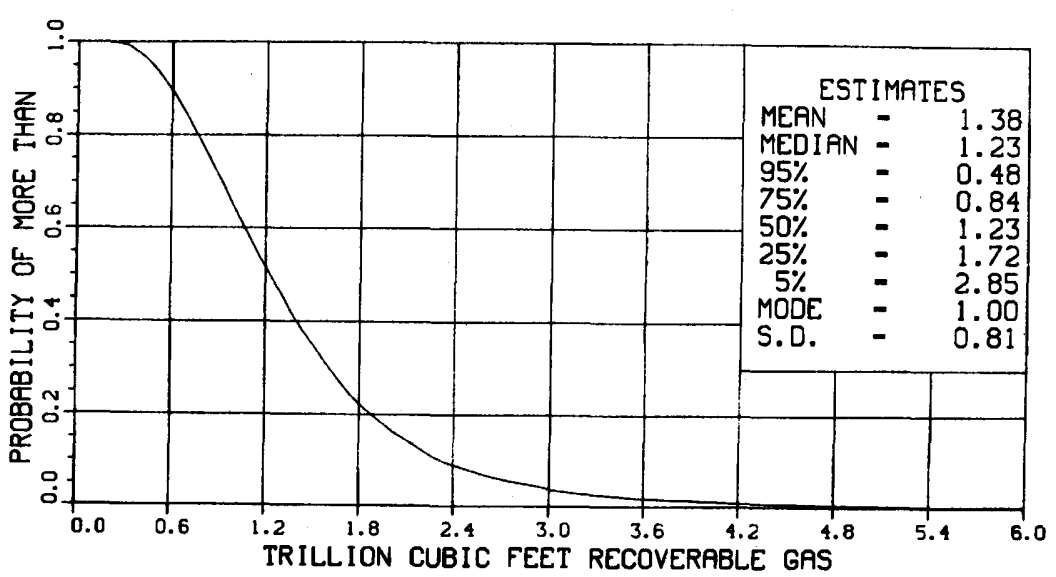

TOTAL GAS

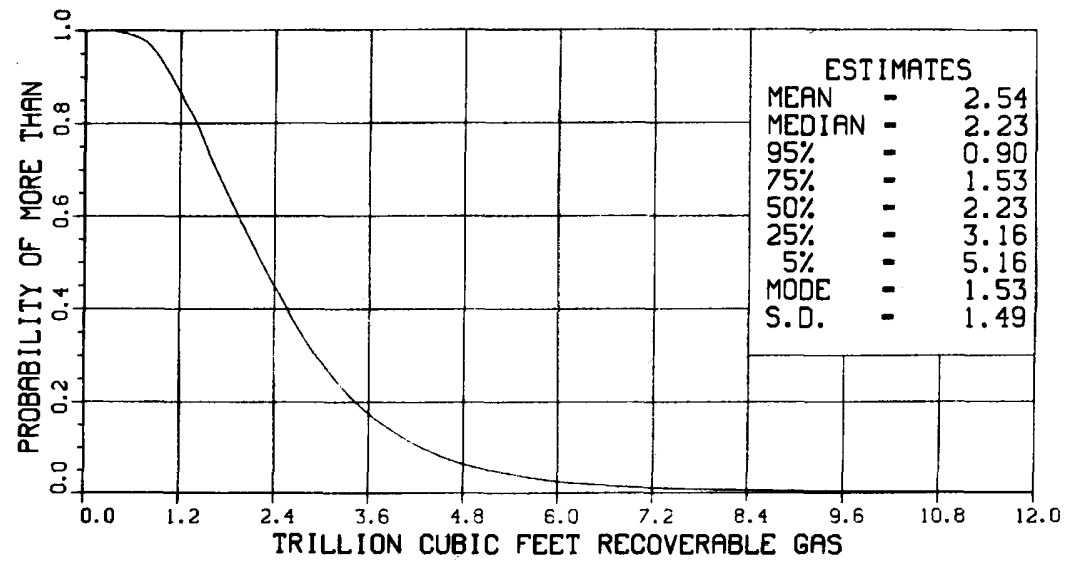

NON-ASSOCIATED GAS

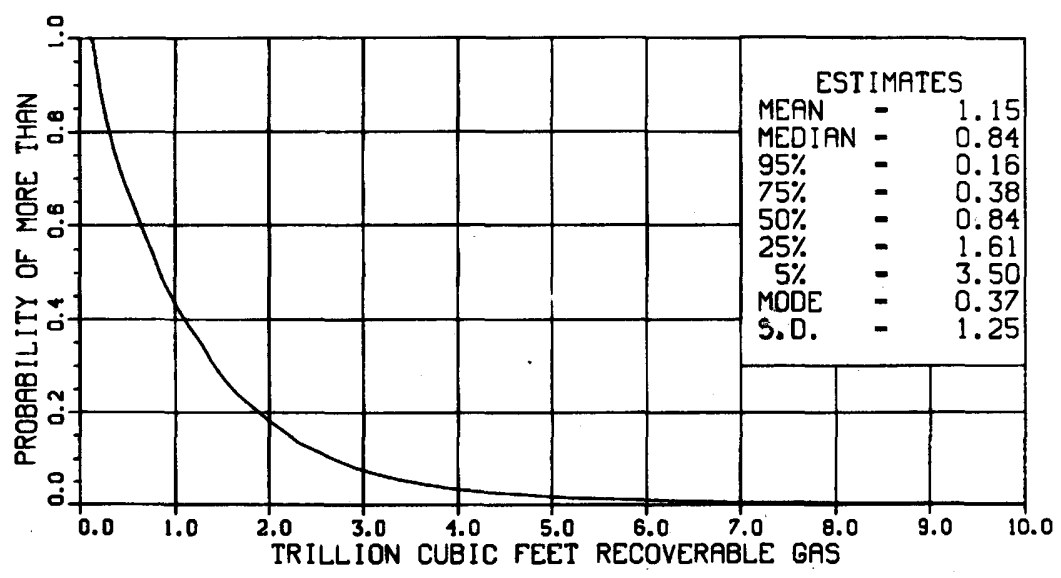

Region 2A.-Pacific Coast shelf 
OIL

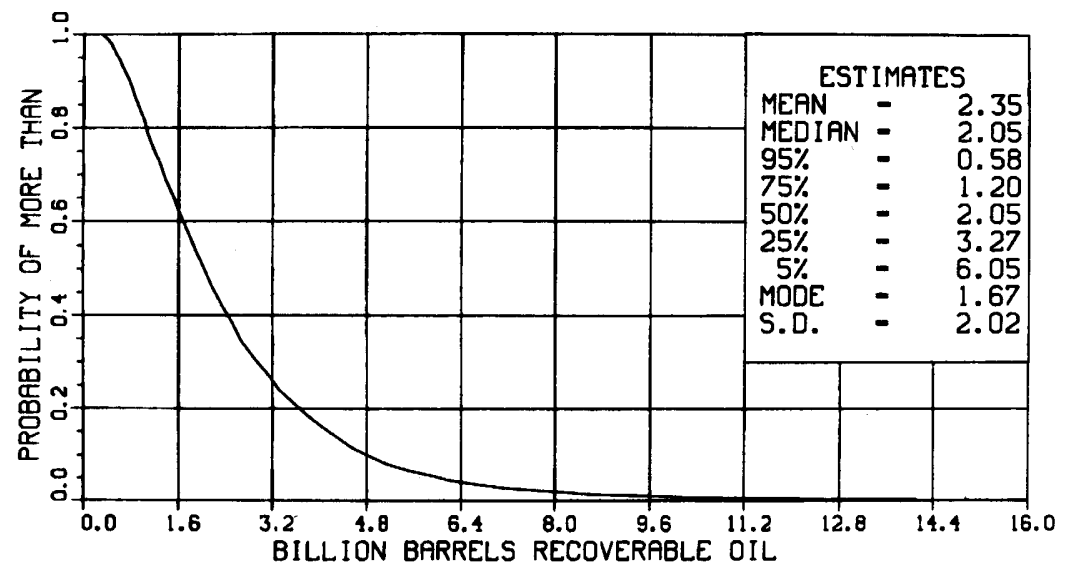

s

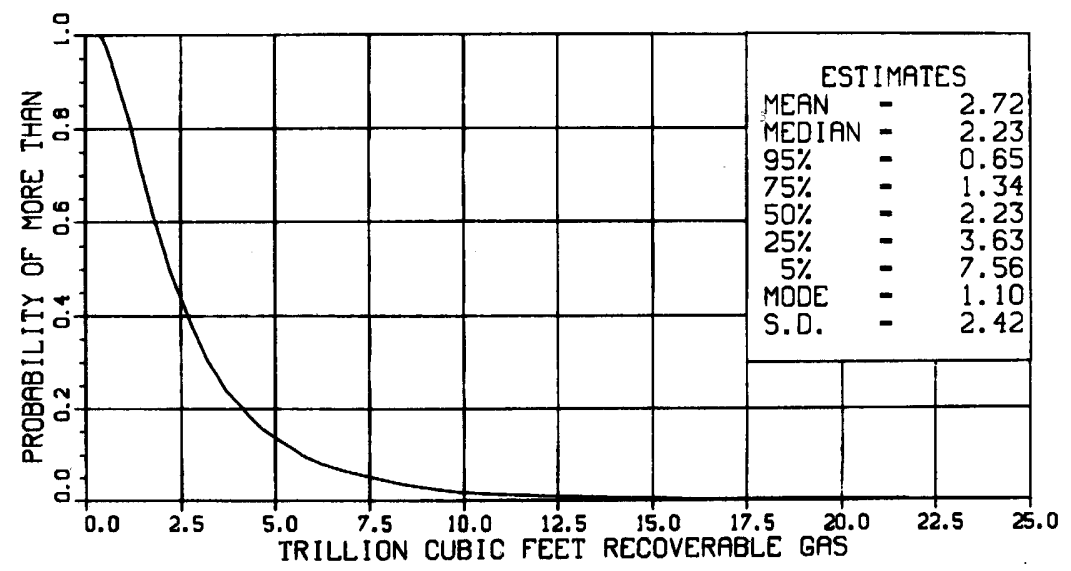

TOTAL GAS

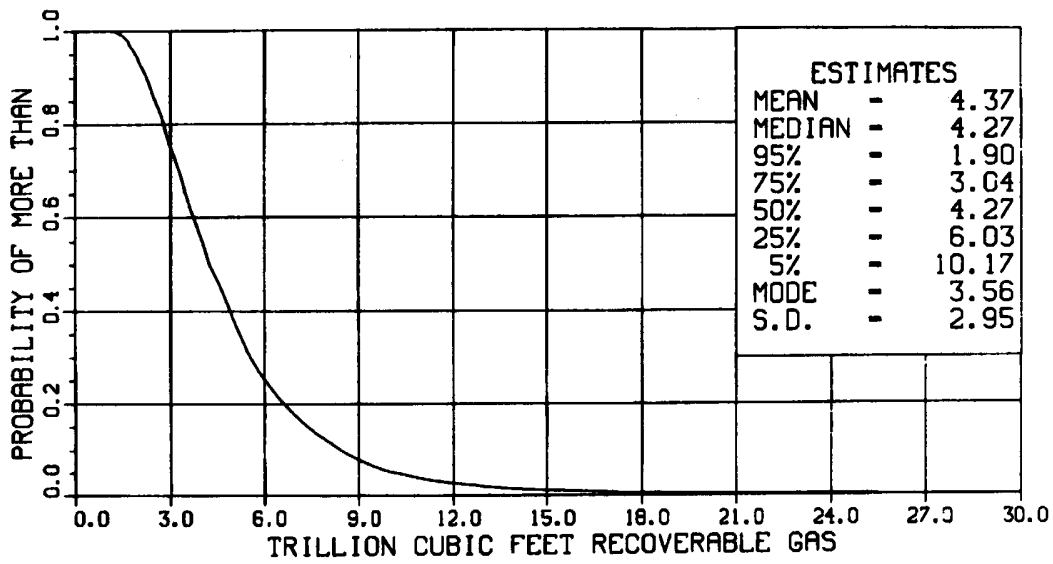

NON-ASSOCIATED GAS

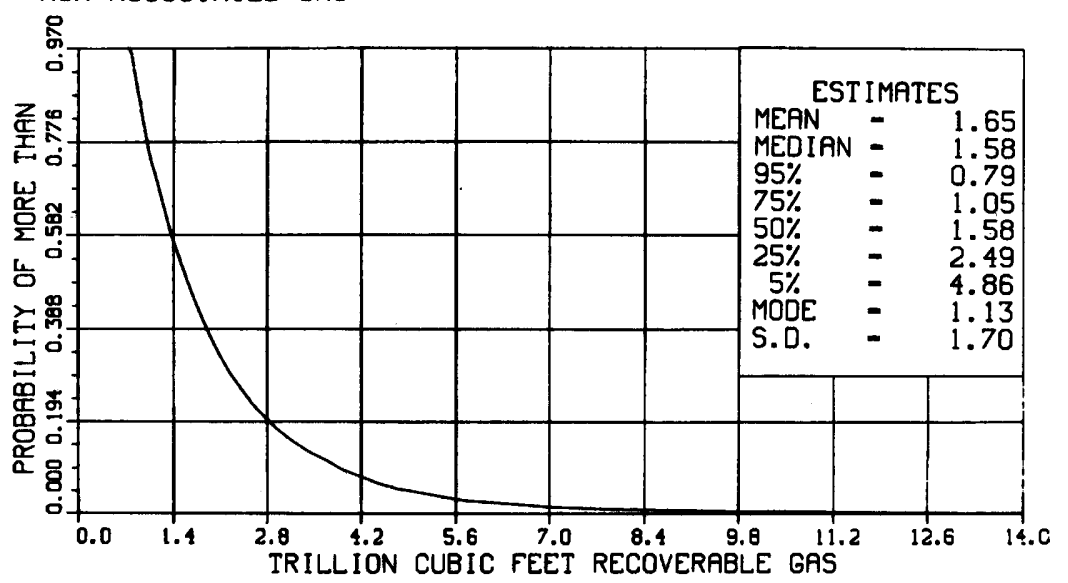

Region 2A.--Pacific Coast slope 
OIL

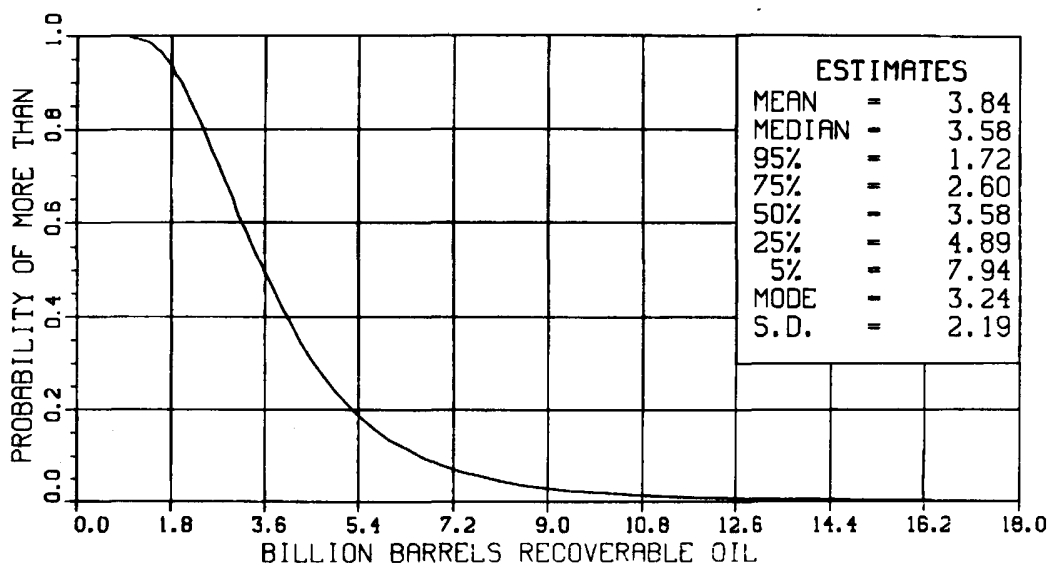

8

ASSOCIATED-DISSOLVED GAS

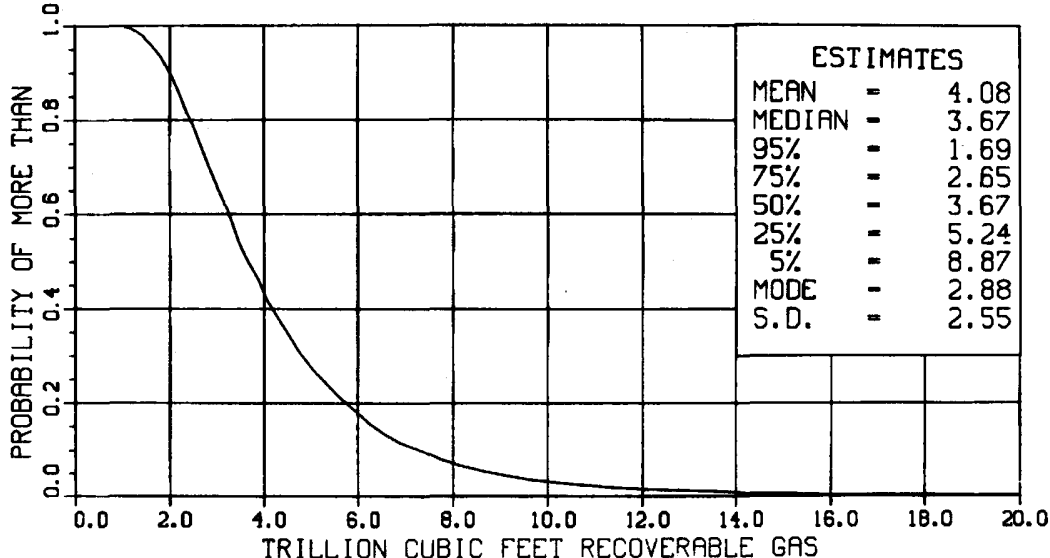

TOTAL GAS

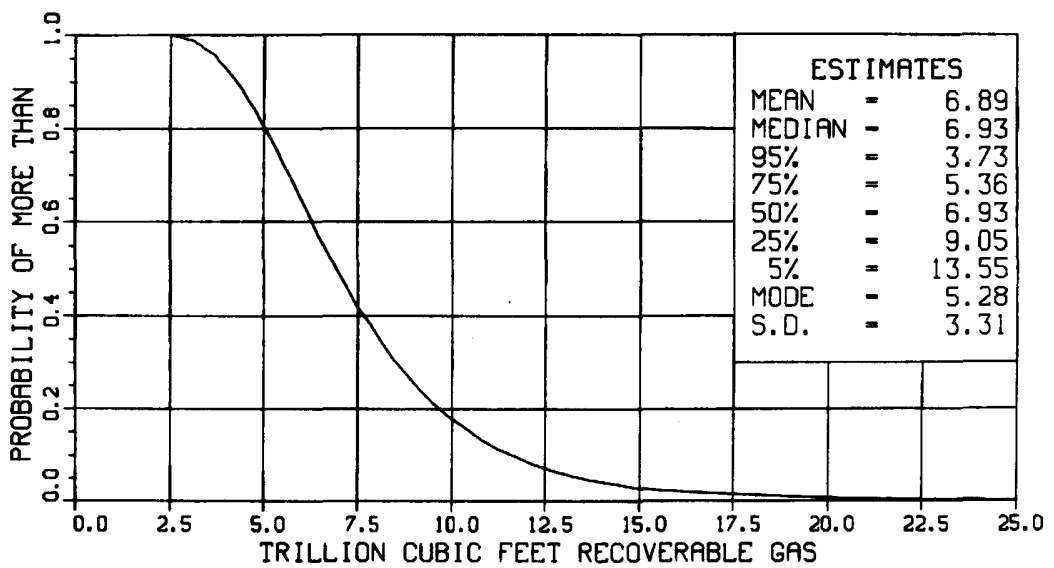

NON-ASSOCIATED GAS

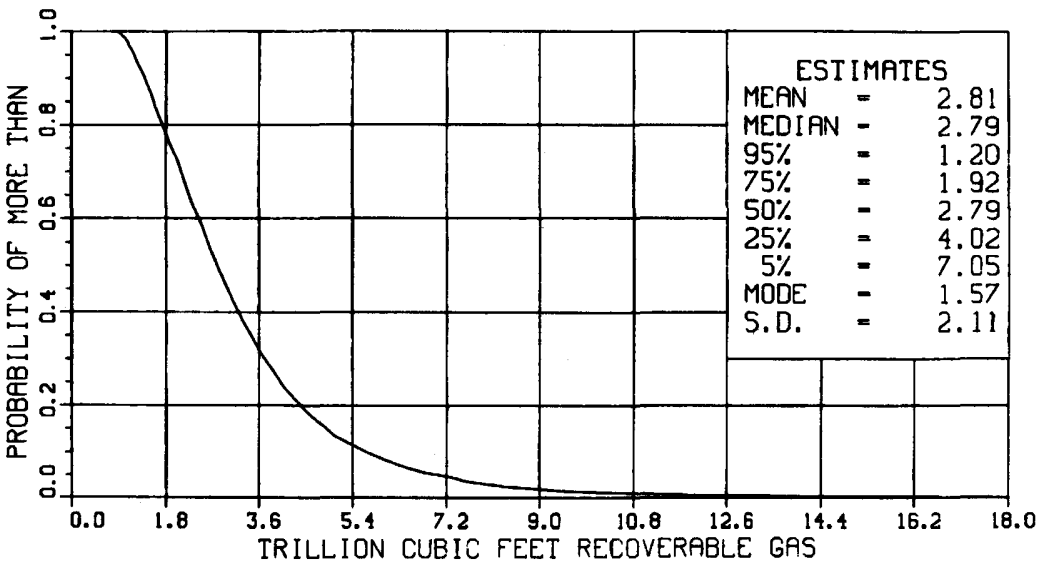

Region 2A.--Pacific Coast entire offshore 
OIL

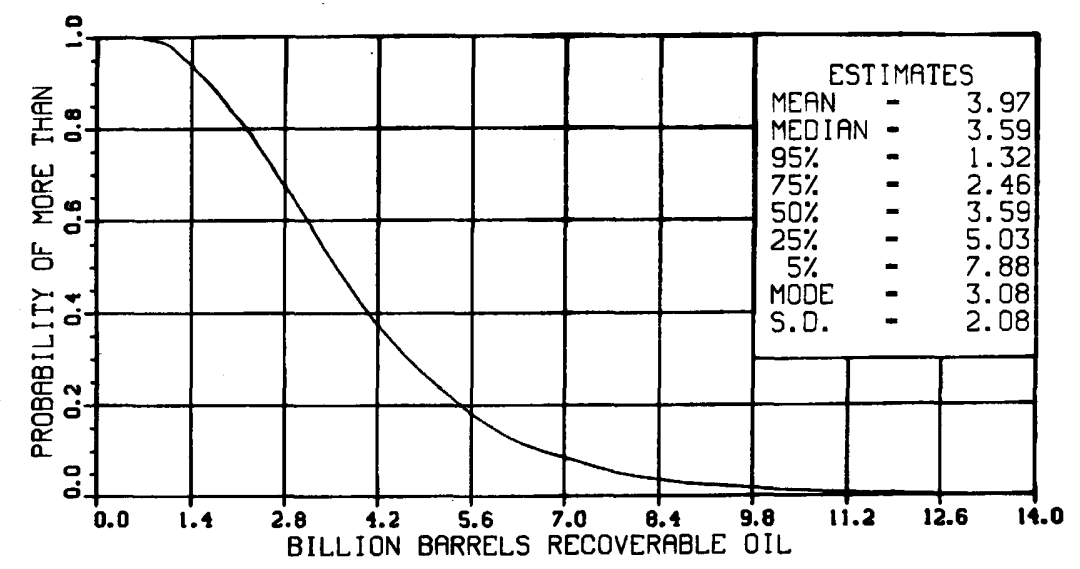

ค ASSOCIATED-DISSOLVED GAS

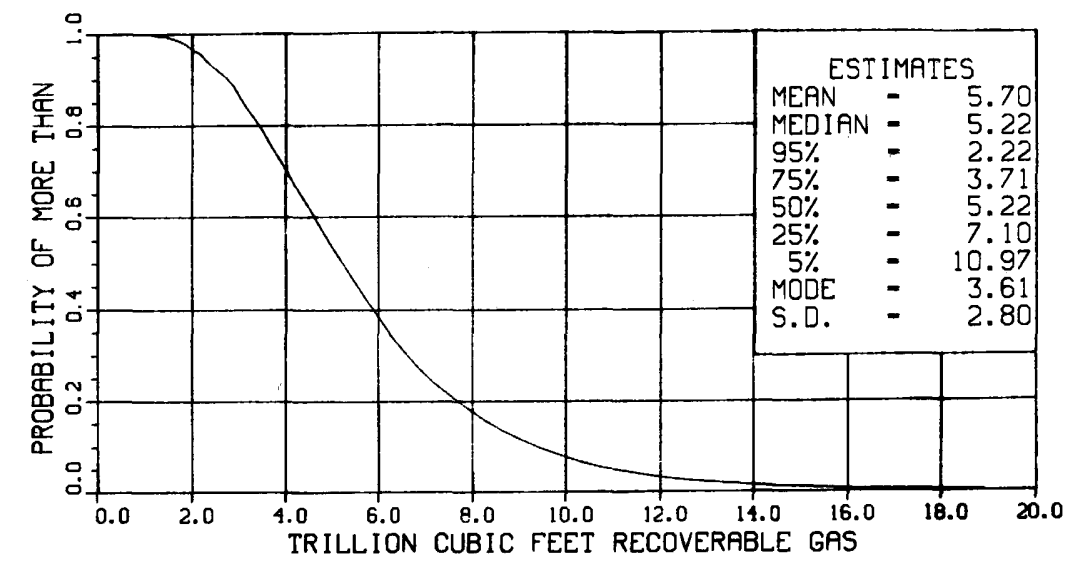

TOTAL GAS

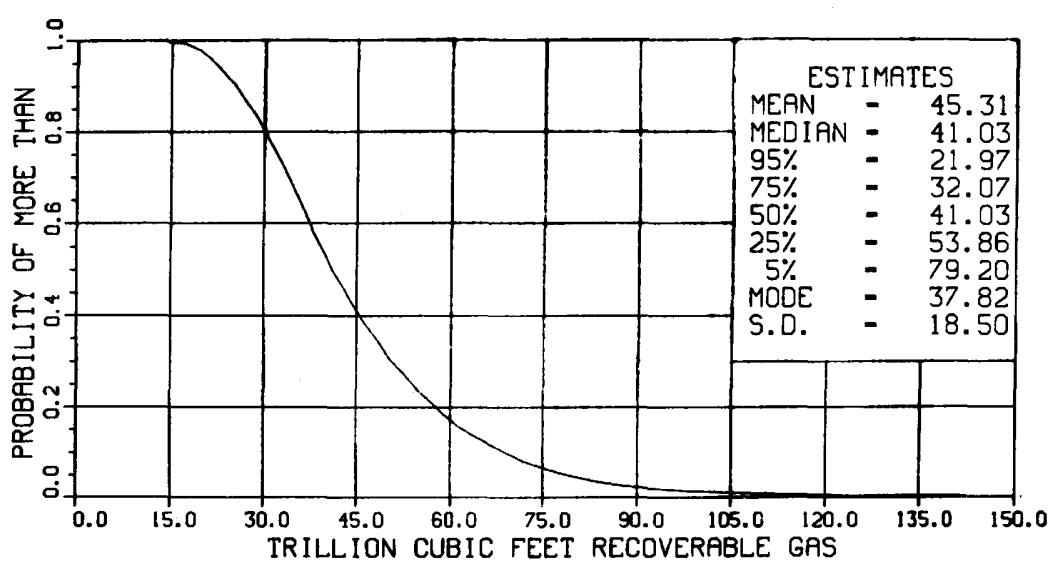

NON-ASSOCIATEO GAS

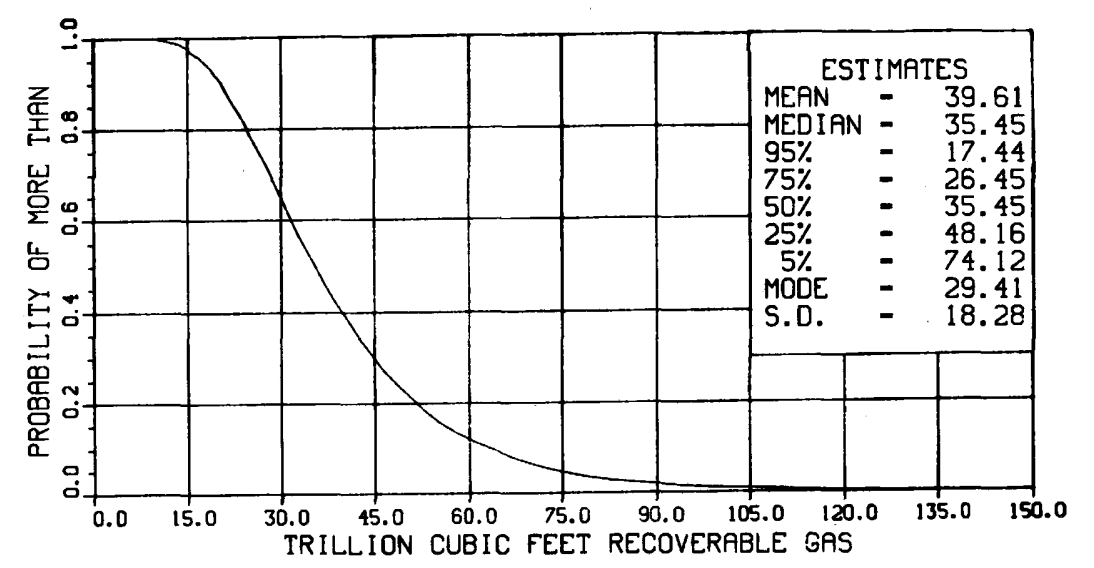

Region 6A.--Gulf of Mexico shelf 
OIL

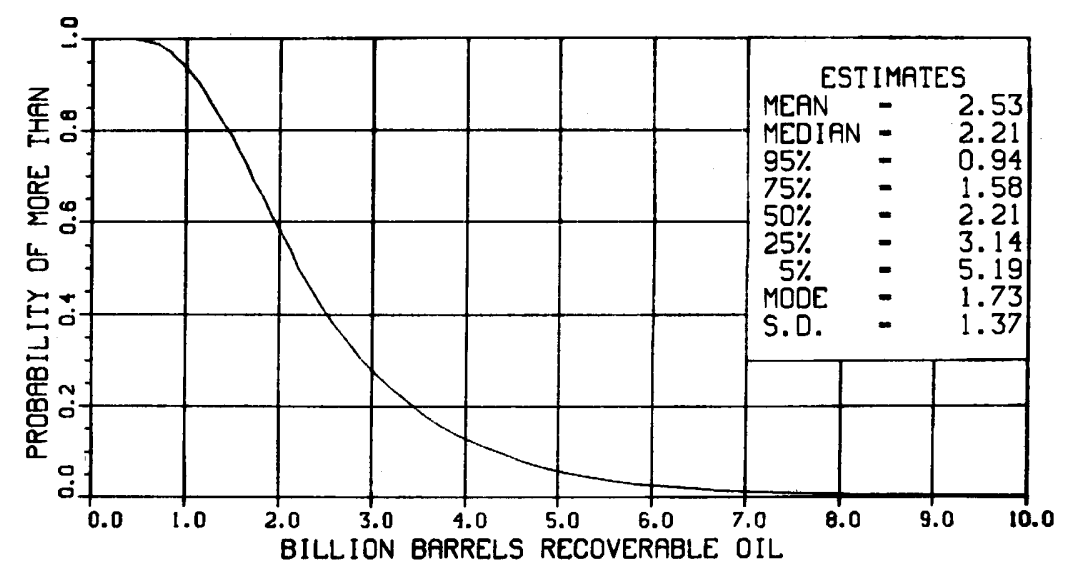

จ

\section{ASSOCIATED-DISSOLVED GAS}

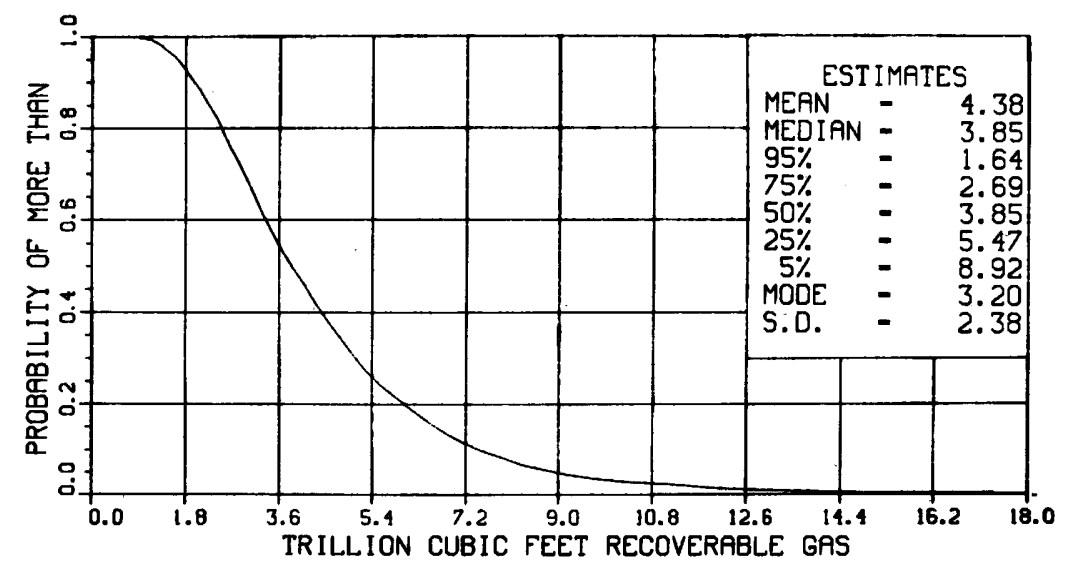

TOTAL GAS

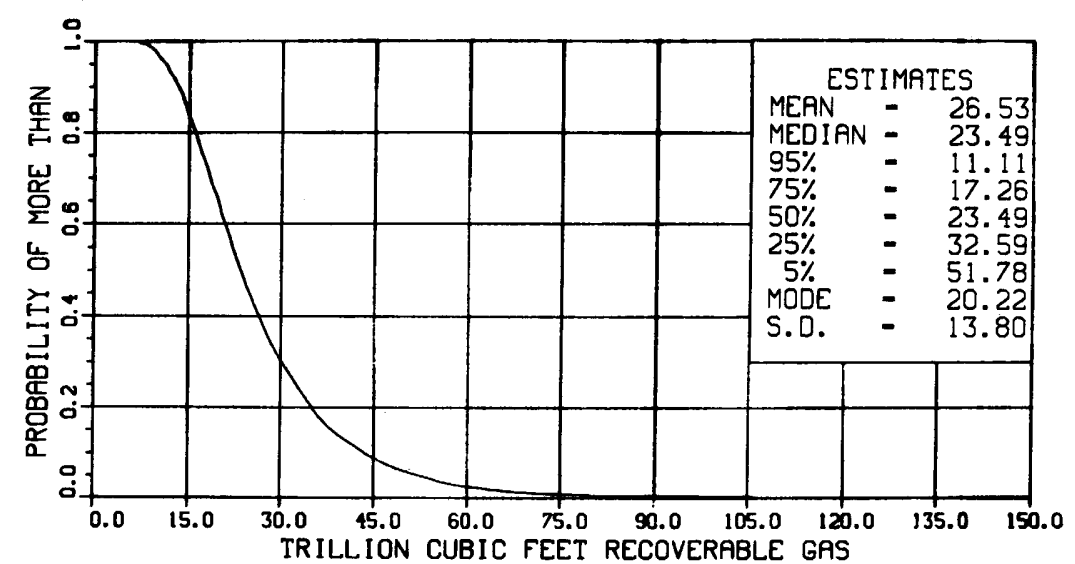

NON-ASSOCIATED GAS

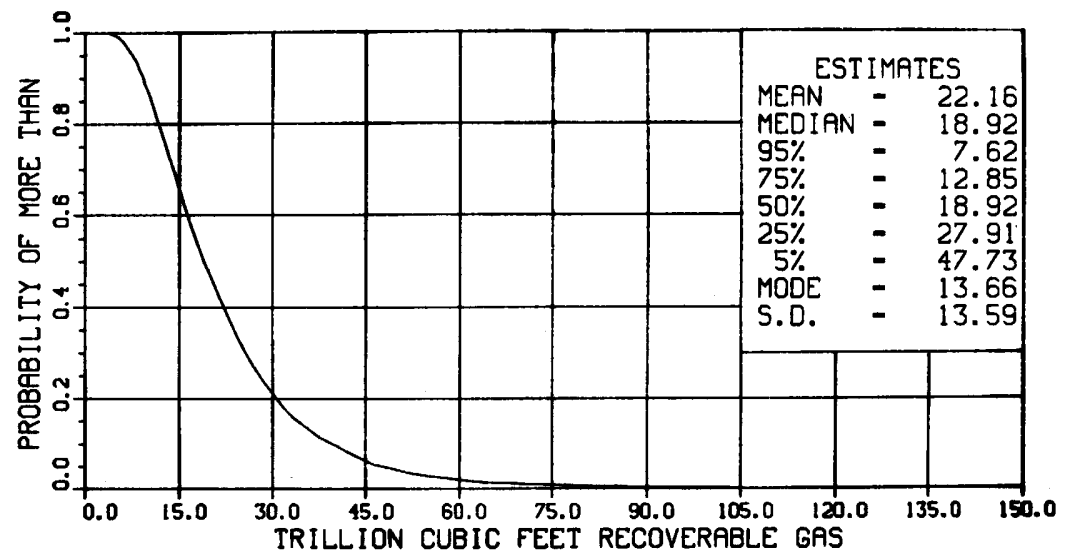

Region 6A.-Gulf of Mexico slope 
OIL

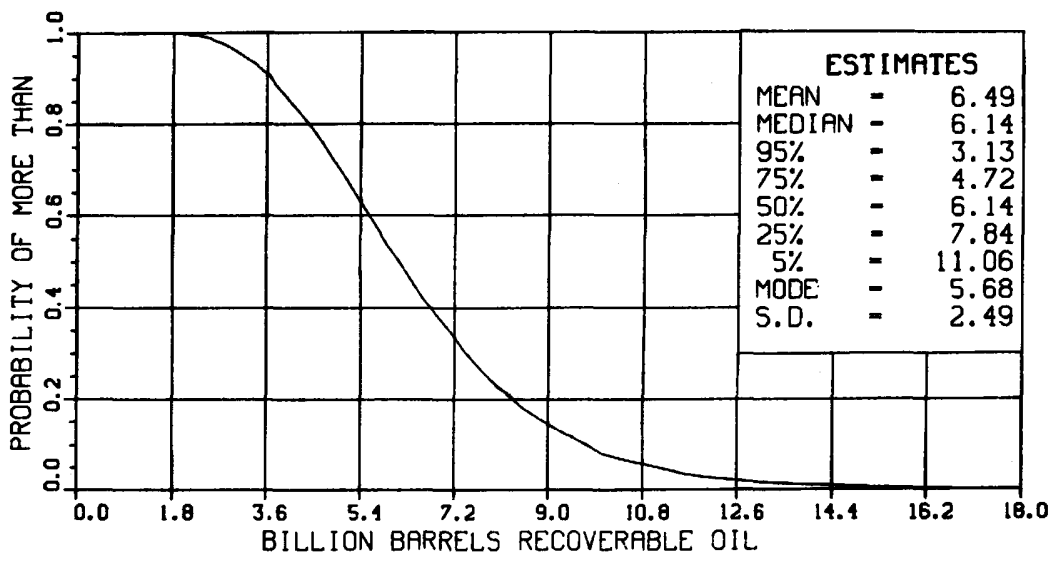

ต

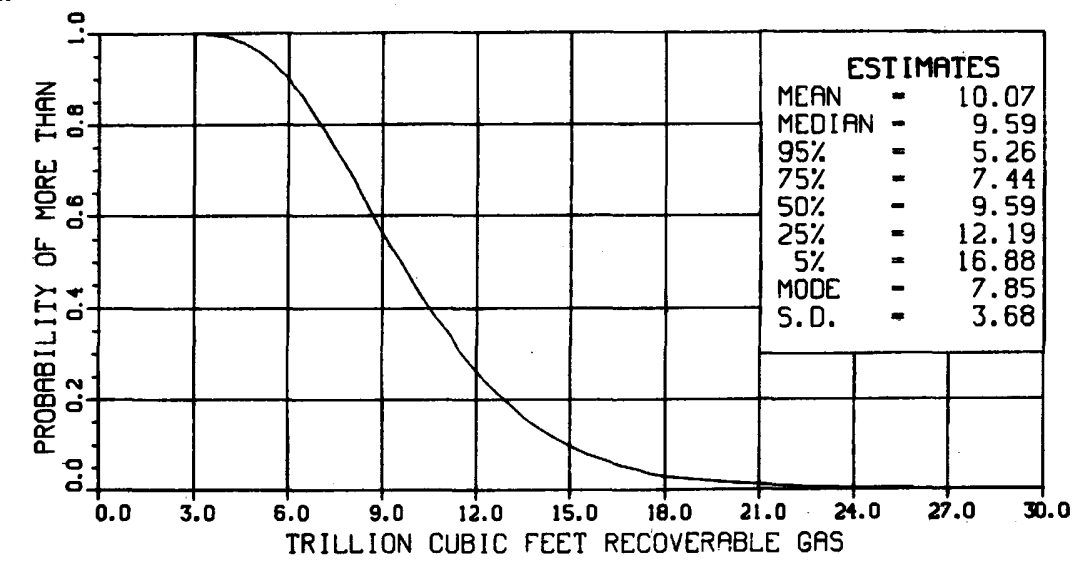

TOTAL GAS

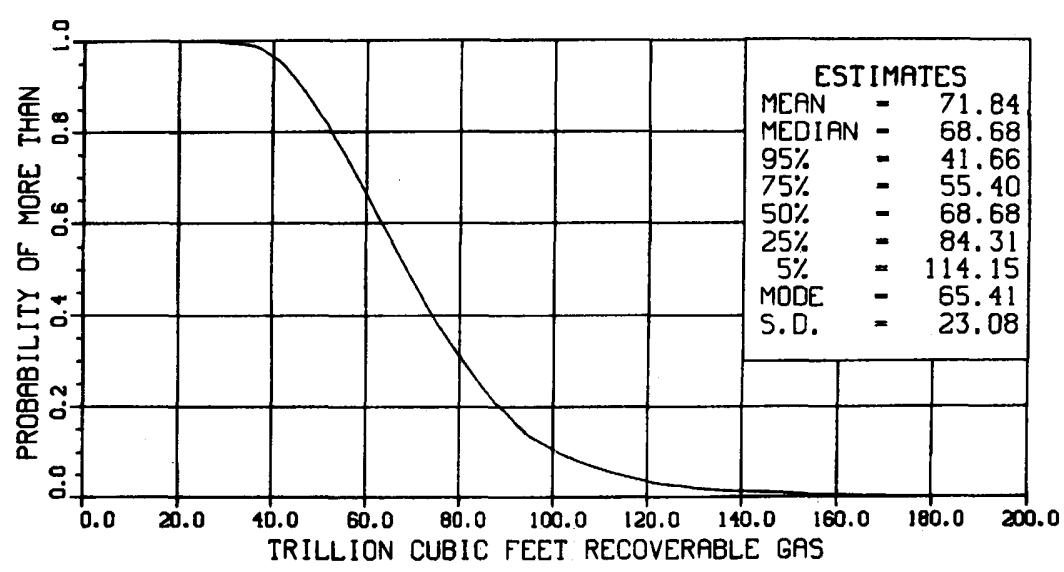

NON-ASSOCIATED GAS

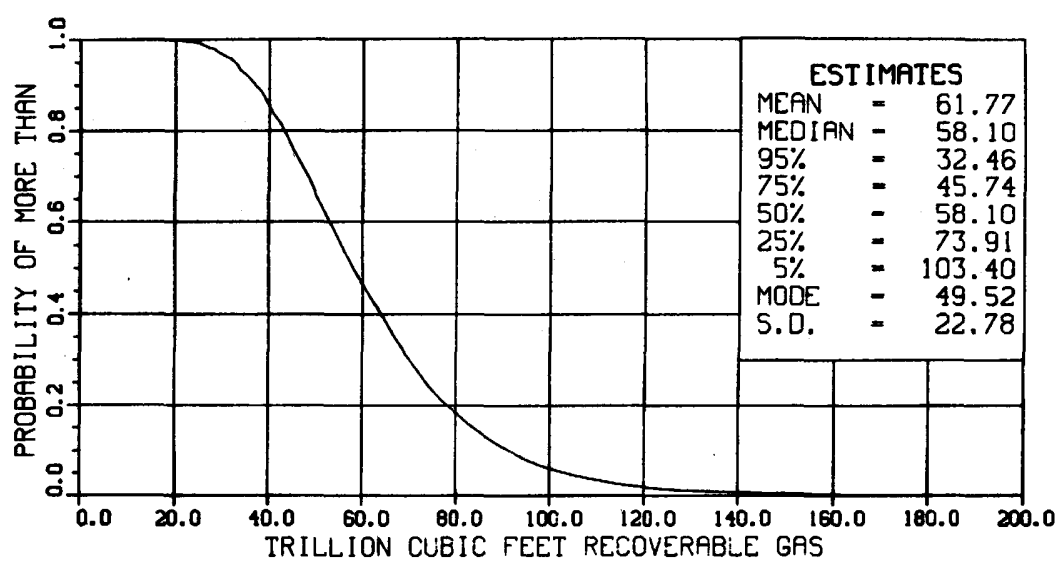

Region 6A.-Gulf of Mexico entire offshore 


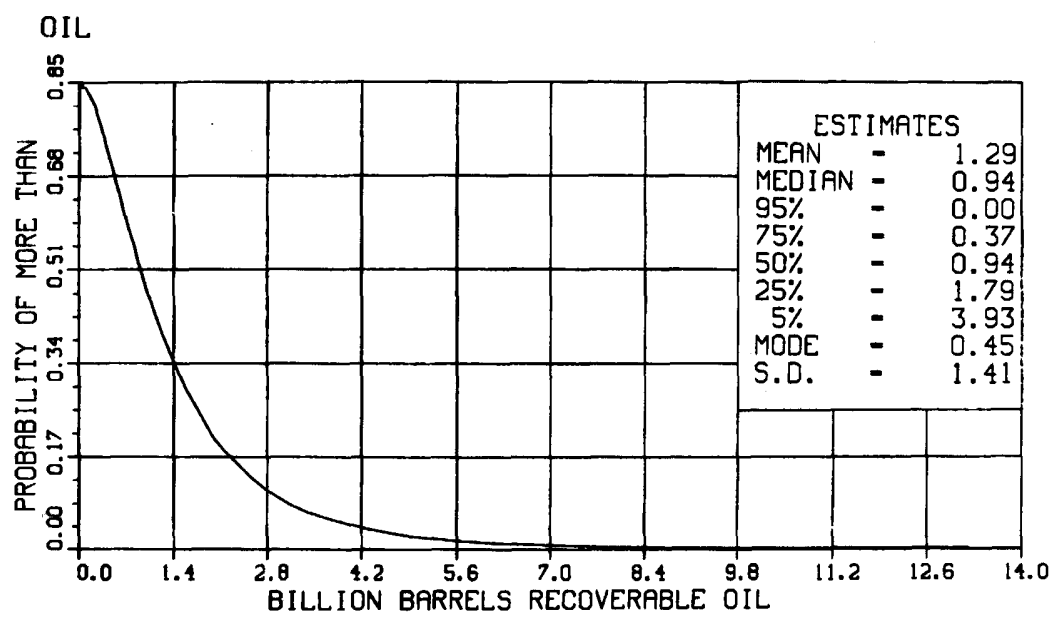

TOTAL GAS

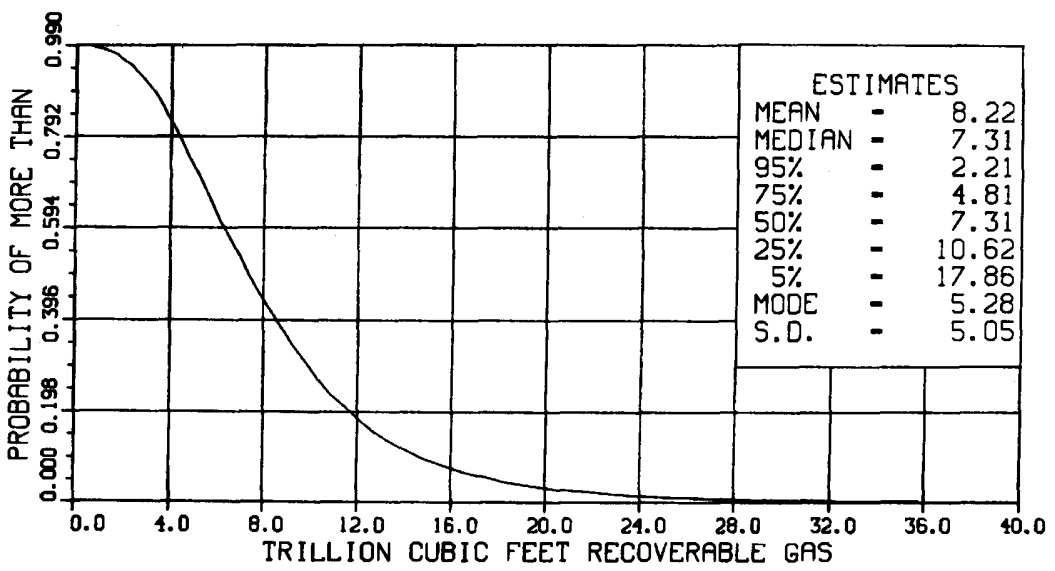

\& ASSOCIATED-DISSOLVED GRS

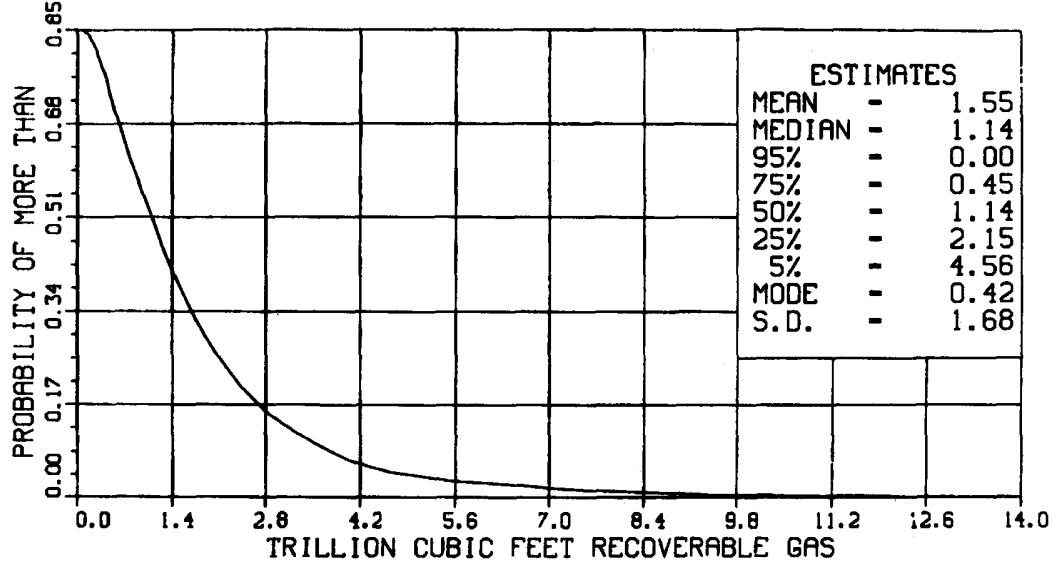

NON-ASSOCIATED GAS

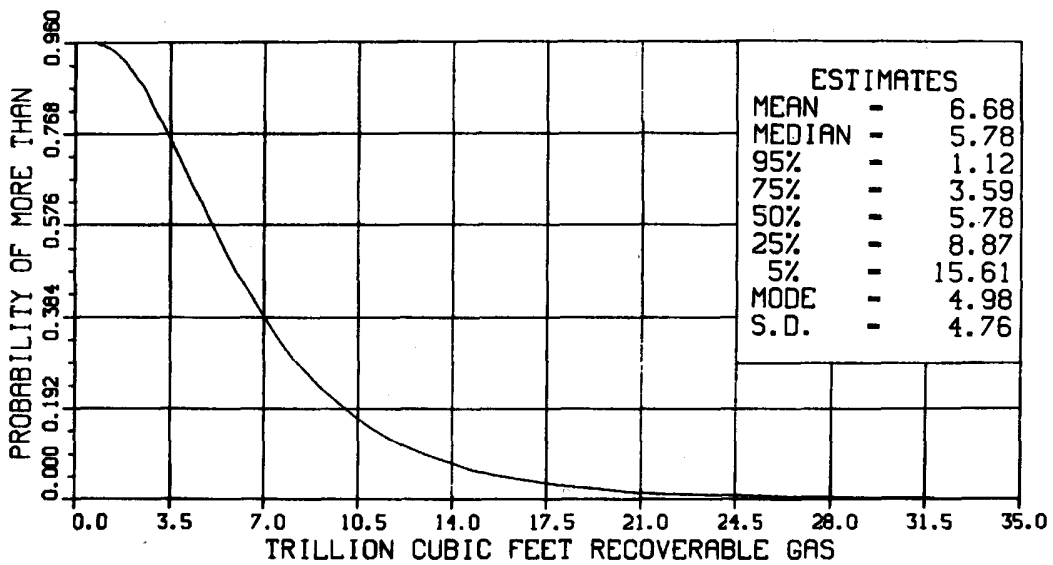

Region 11A.--Atlantic Coast shelf 

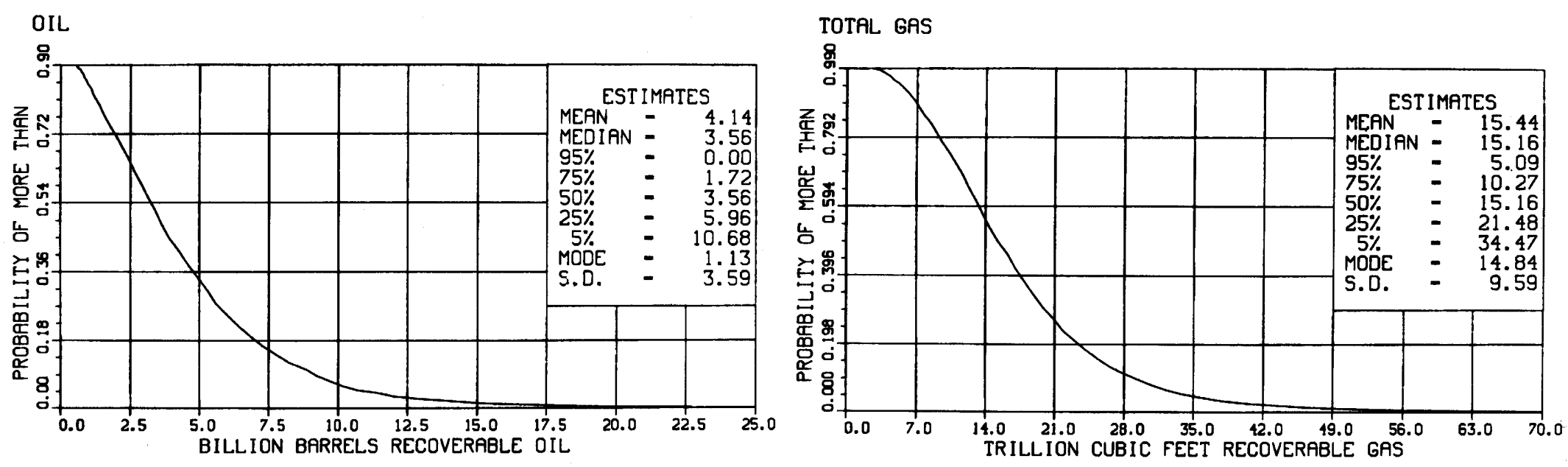

요

\section{ASSOCIATED-DISSOLVED GAS}

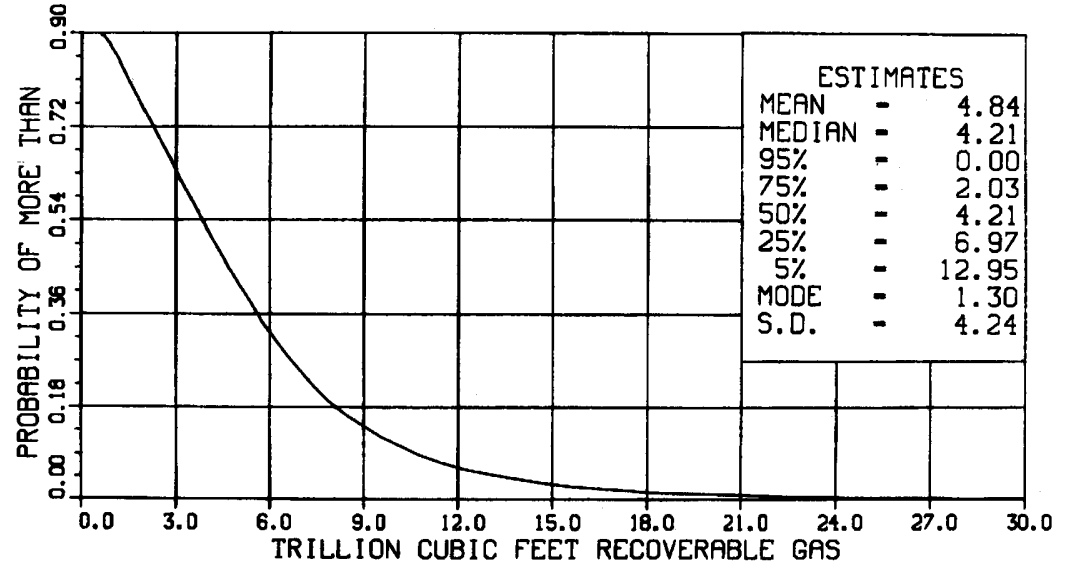

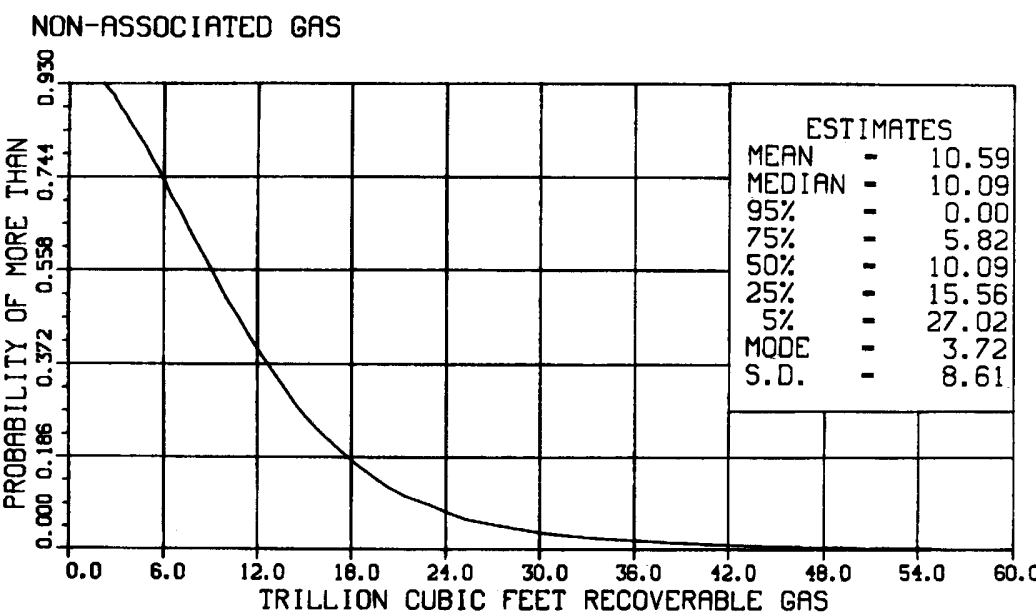

Region 11A.-Atlantic Coast slope 


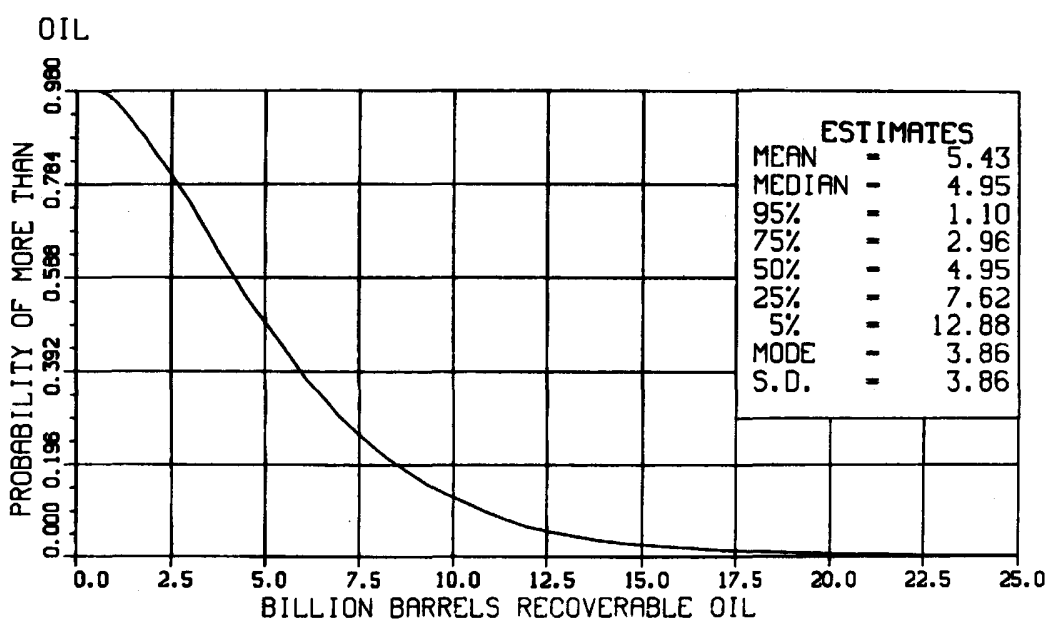

TOTAL GAS

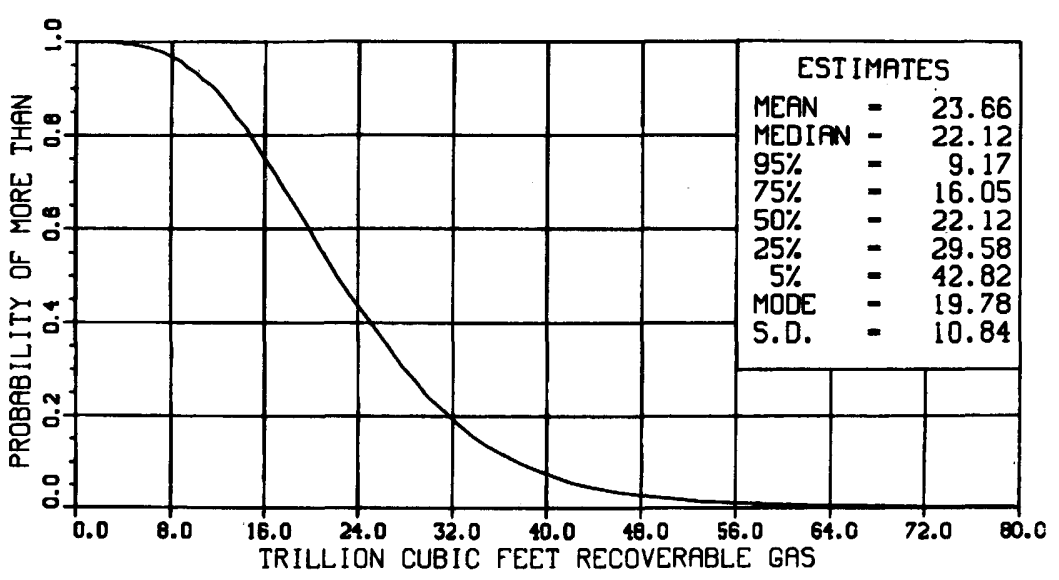

\& ASSOCIRTED-DISSOLVED GAS
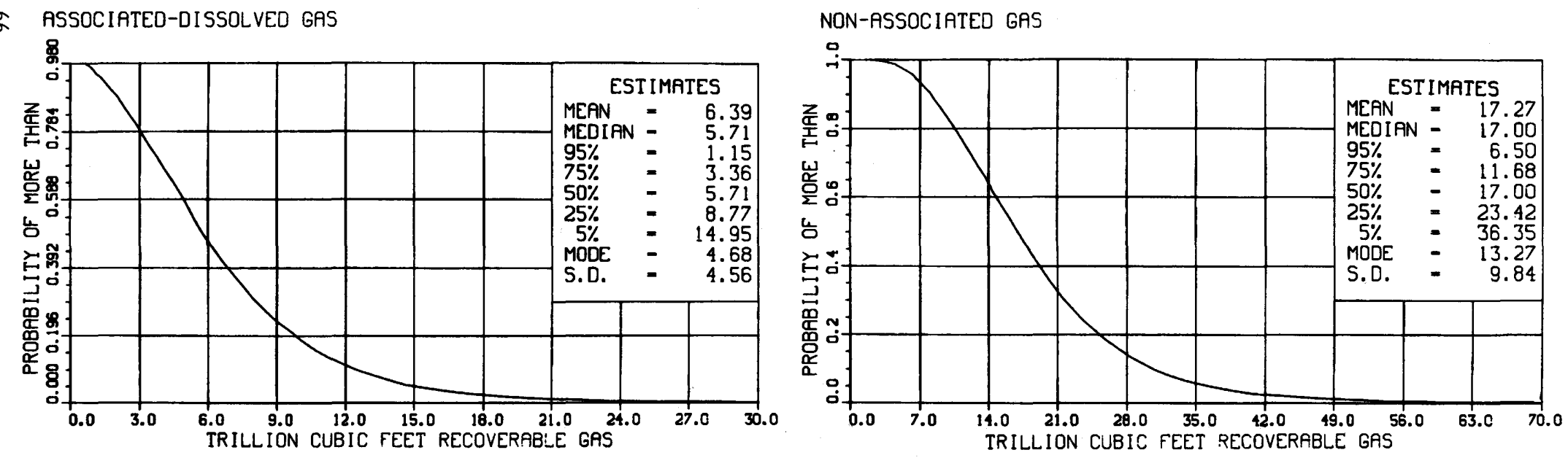

Region 11A.--Atlantic Coast entire offshore 
OIL

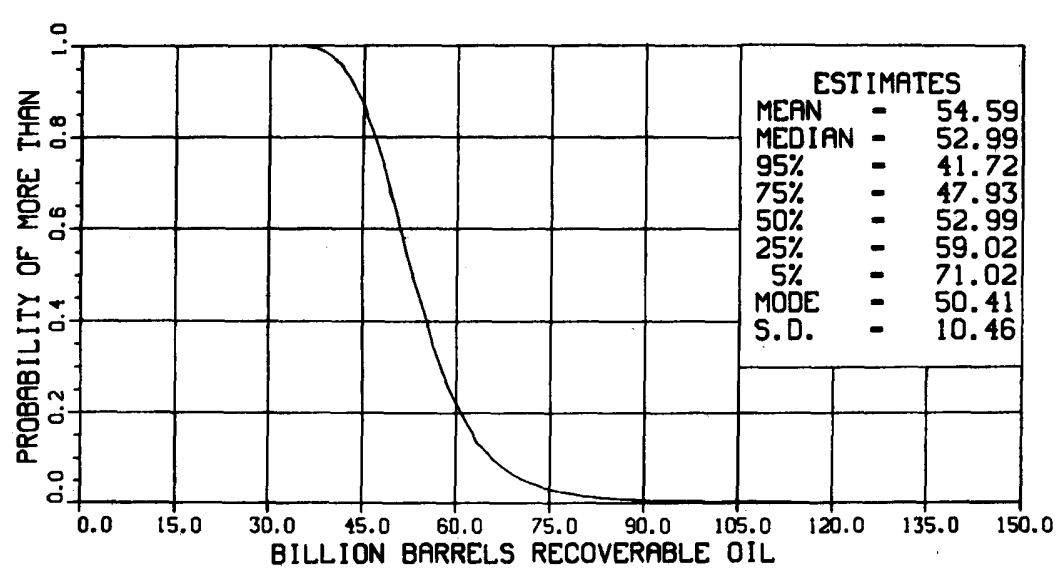

$\approx$ ASSOCIATED-DISSOLVED GAS

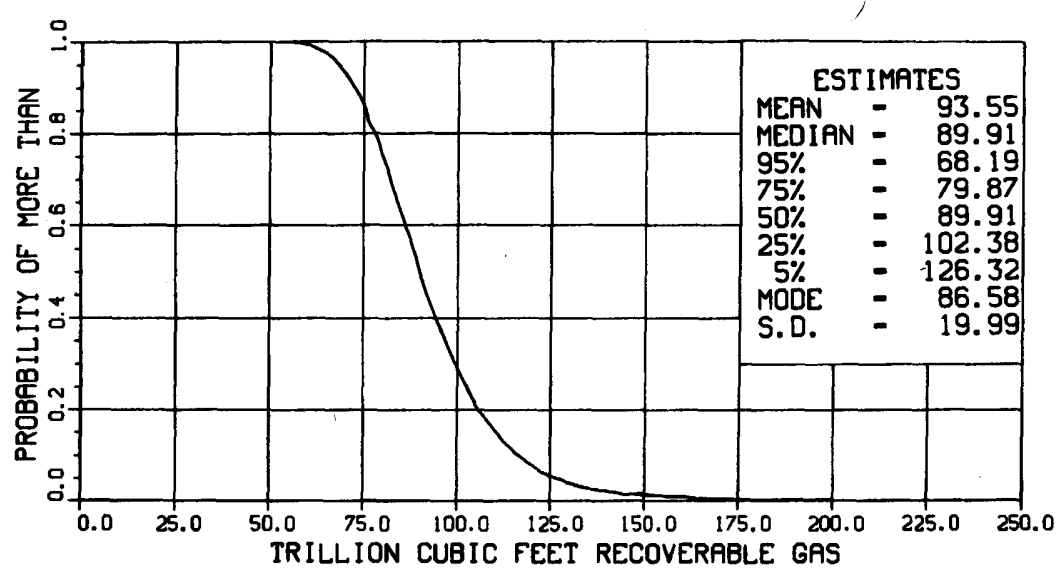

TOTAL GAS

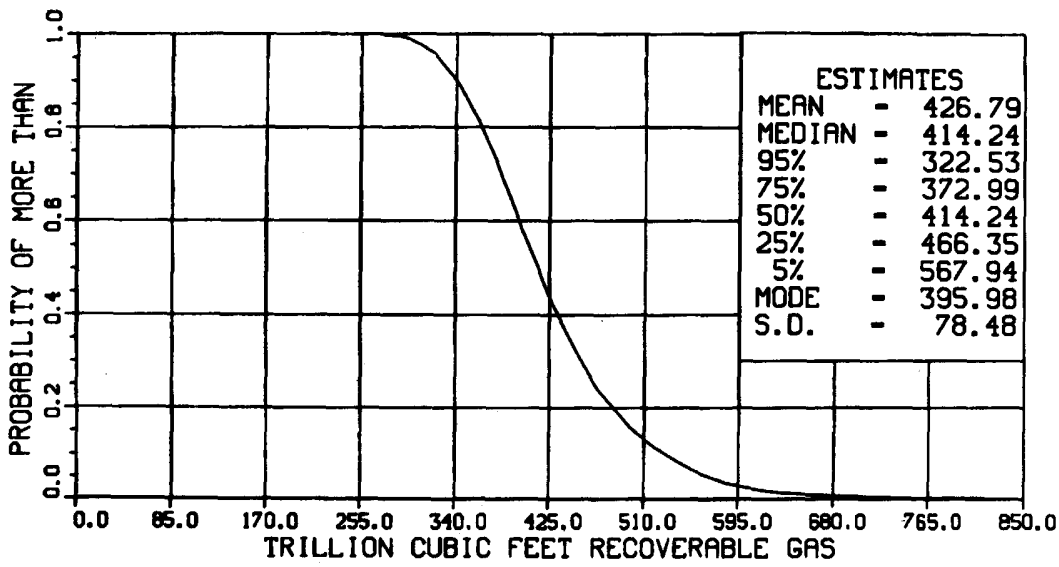

NON-ASSOCIATED GAS

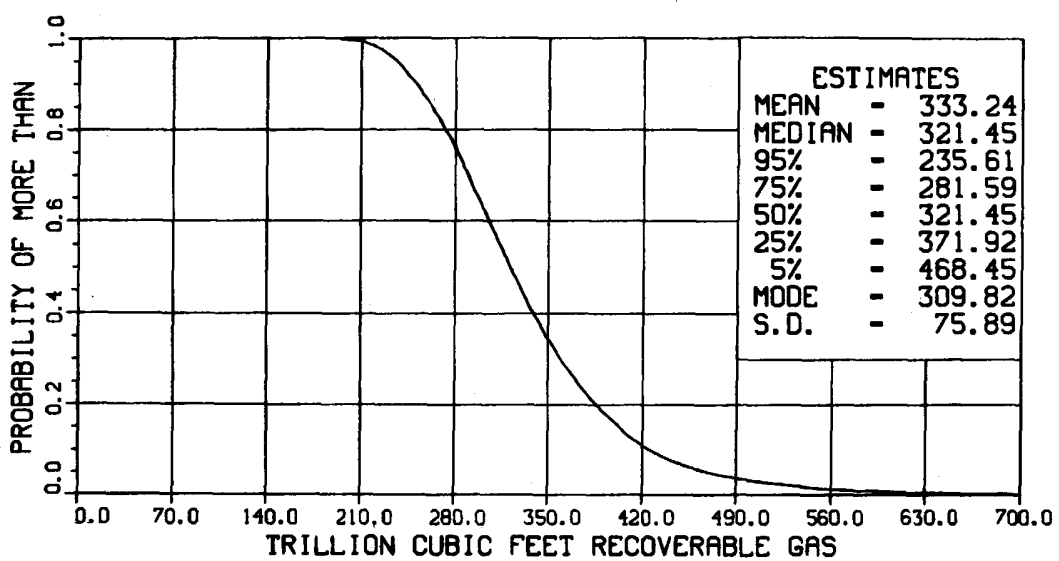

Entire onshore 
OIL

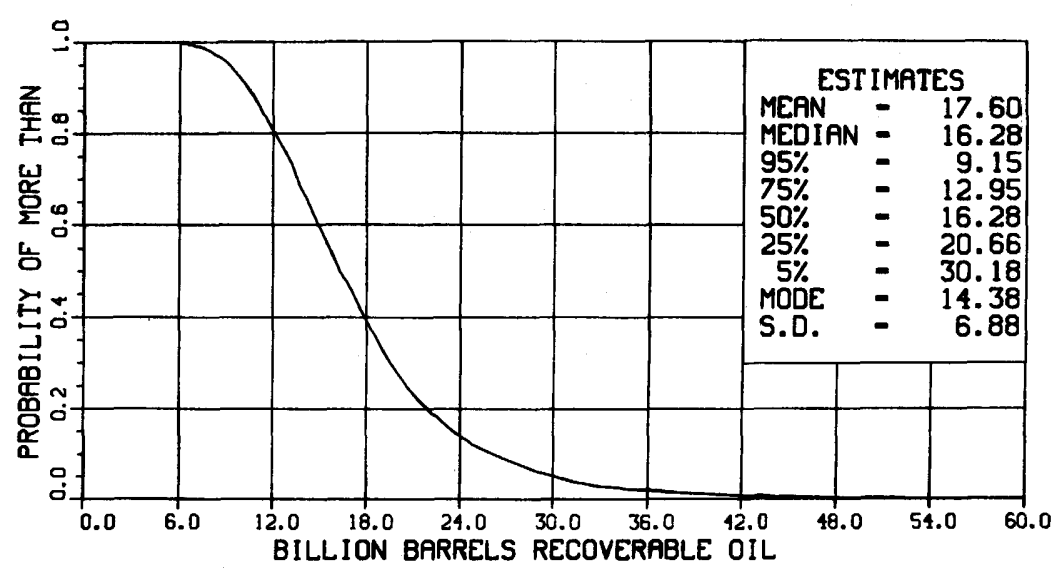

ळ

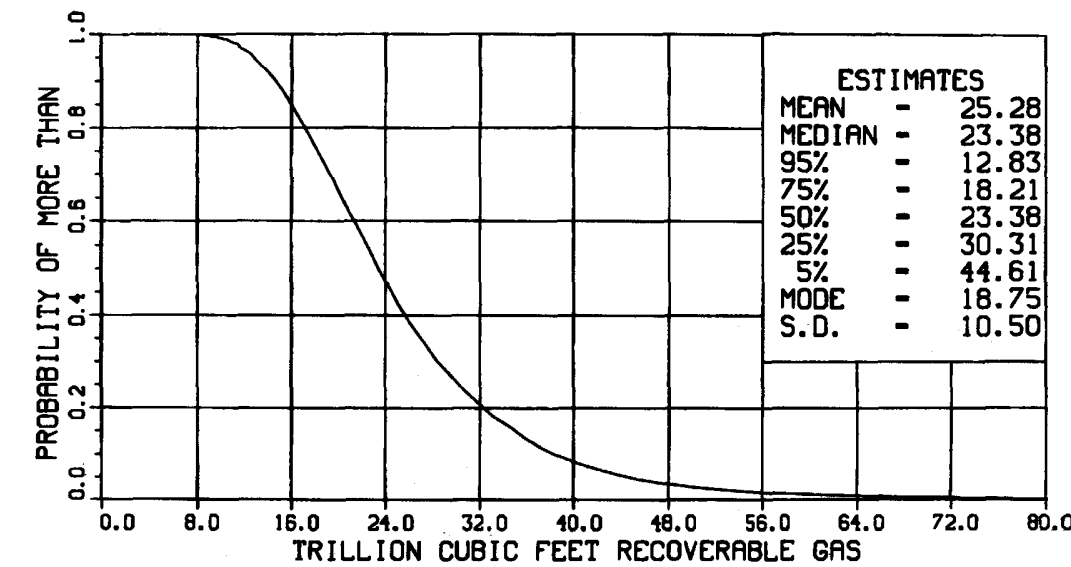

TOTAL GAS

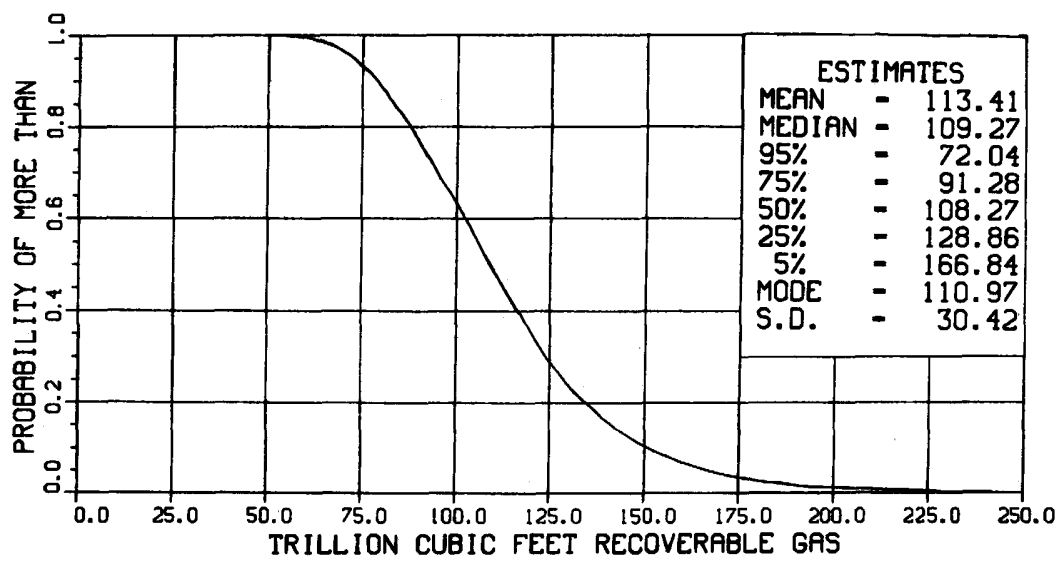

NON-ASSOCIATED GAS

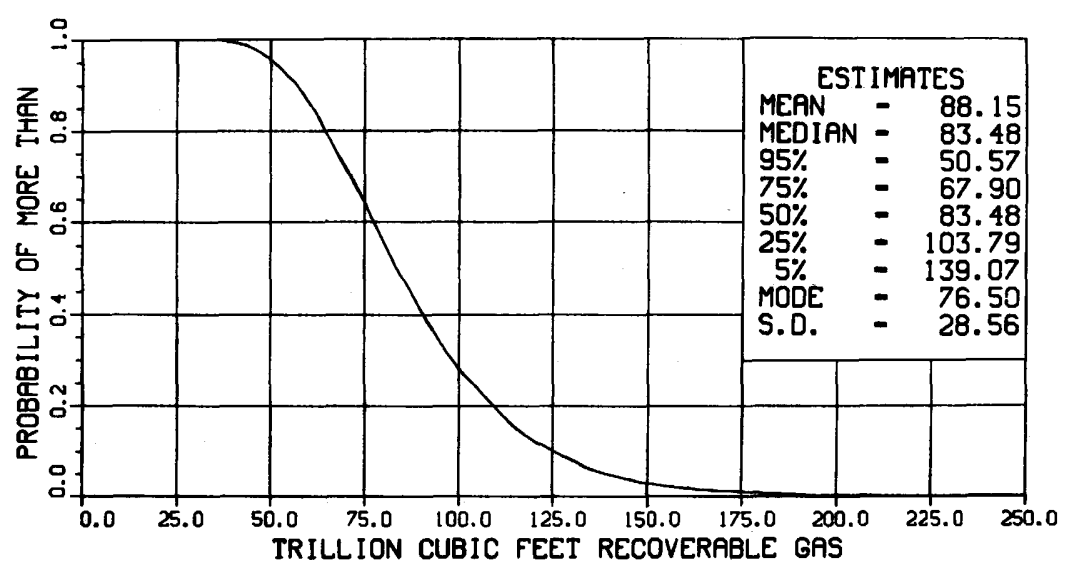

Entire shelf 
OIL

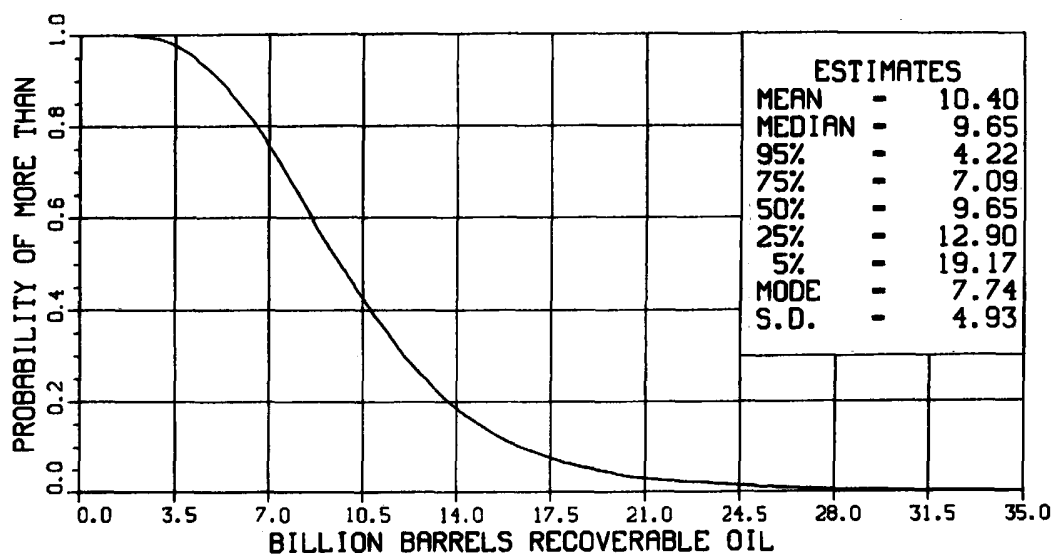

of ASSOCIATED-DISSOLVED GAS

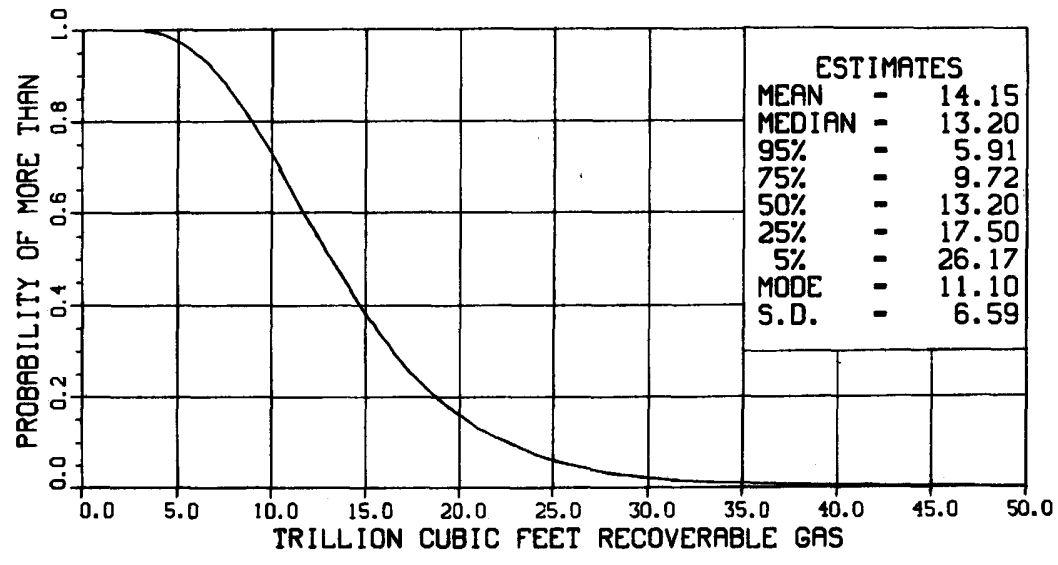

TOTAL GAS

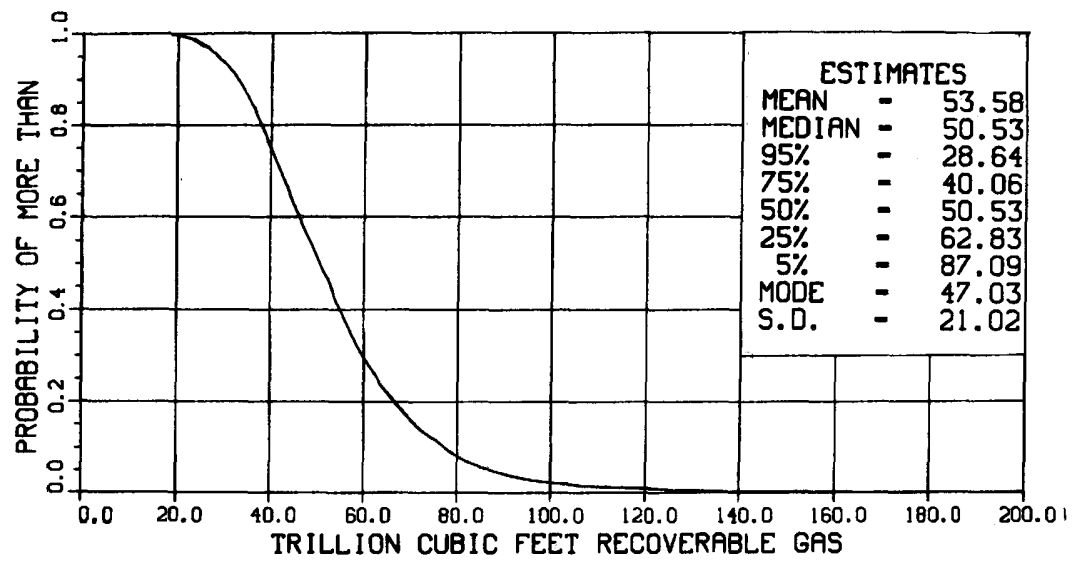

NON-ASSOCIATED GAS

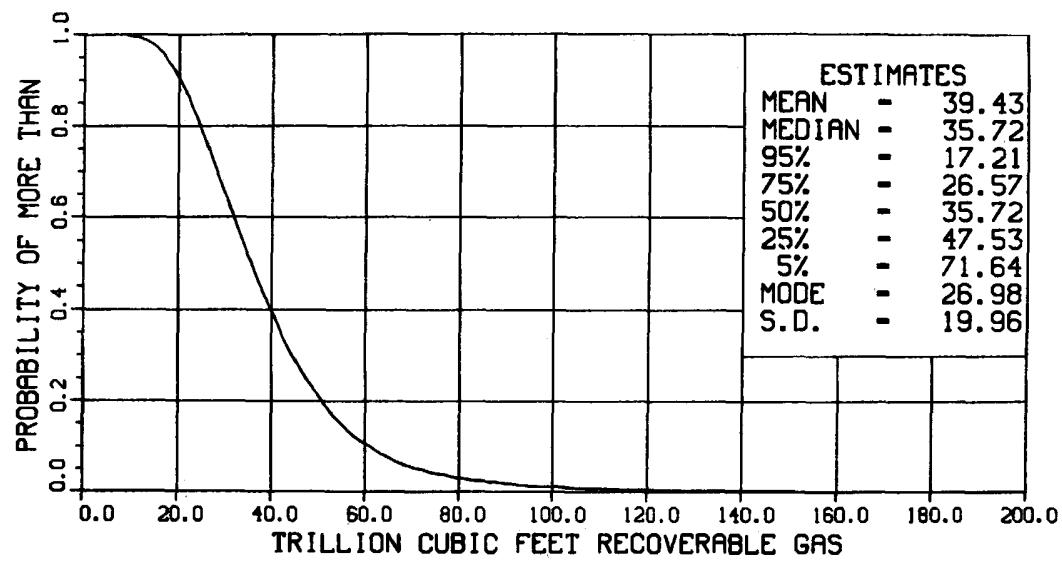


OIL

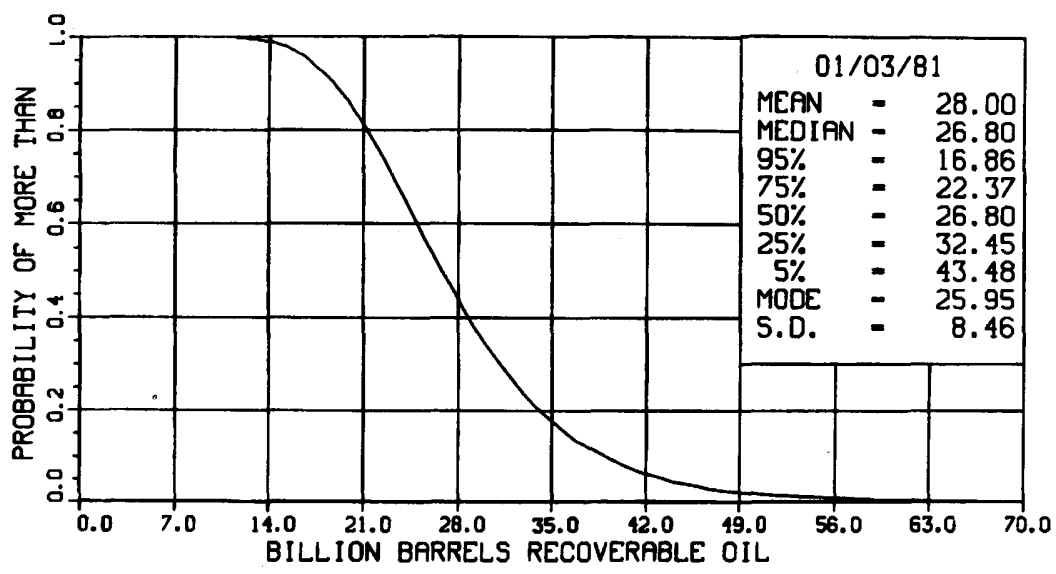

ठ ASSOCIATED-DISSOLVED GAS

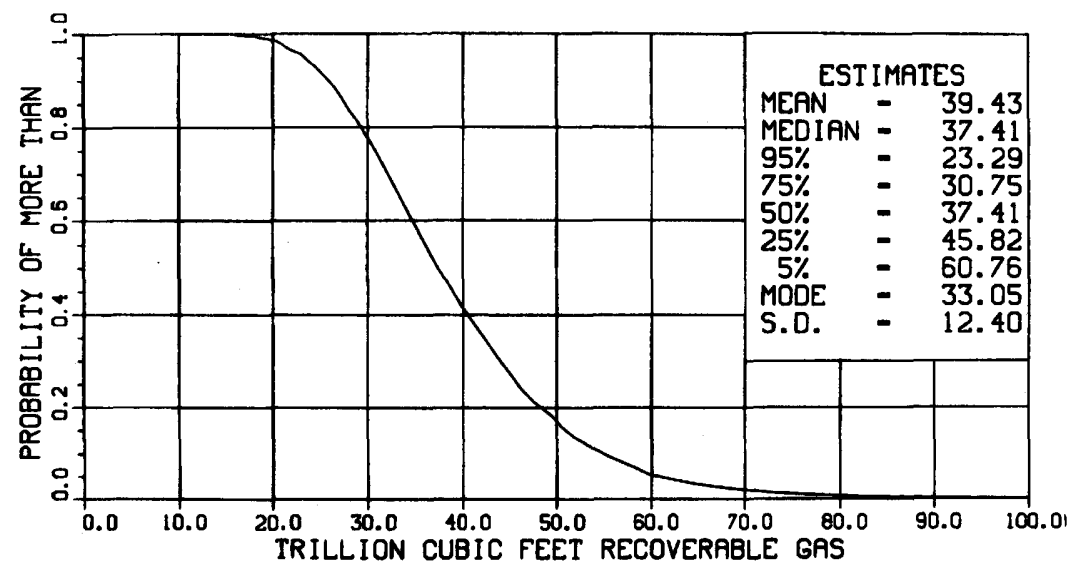

TOTAL GAS

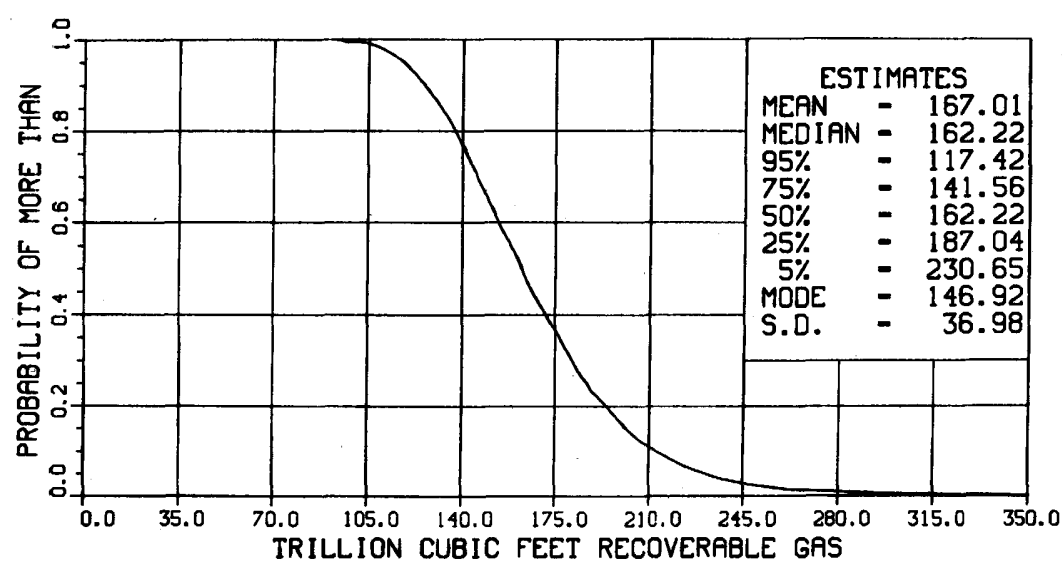

NON-ASSOCIATEO GAS

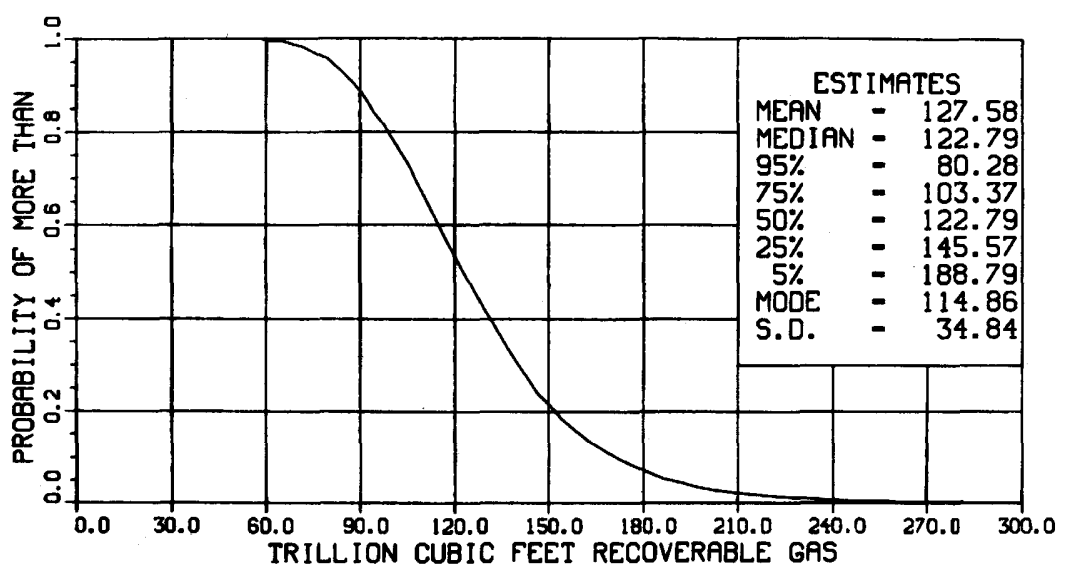

Entire offshore 
OIL

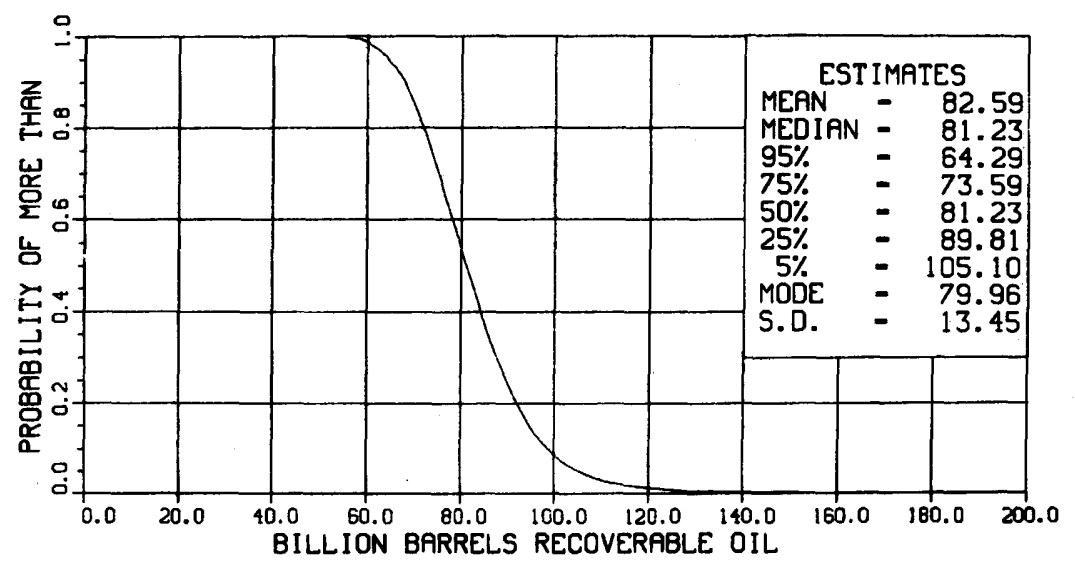

$\beth$

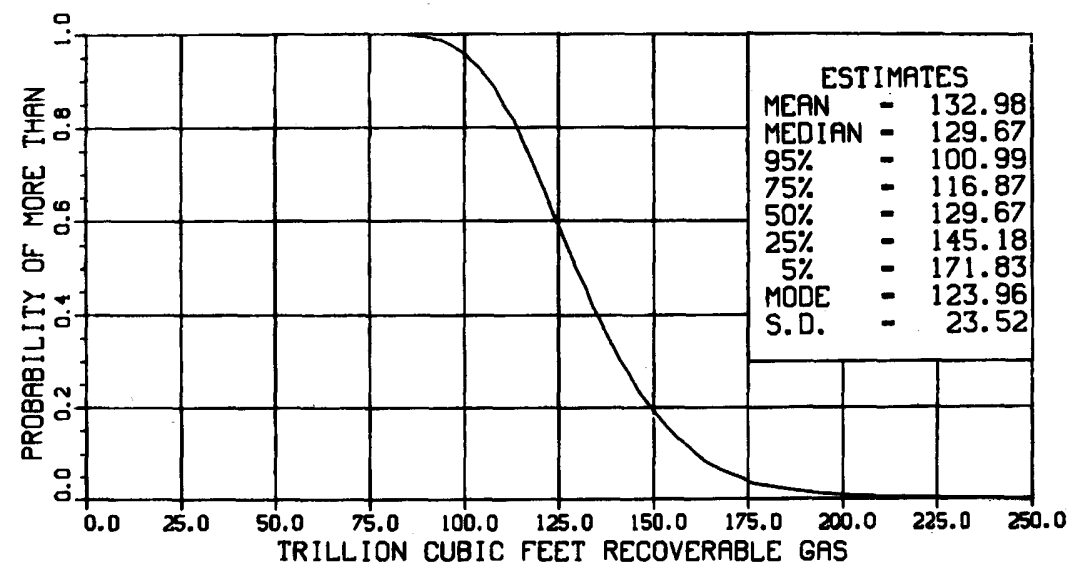

TOTAL GAS

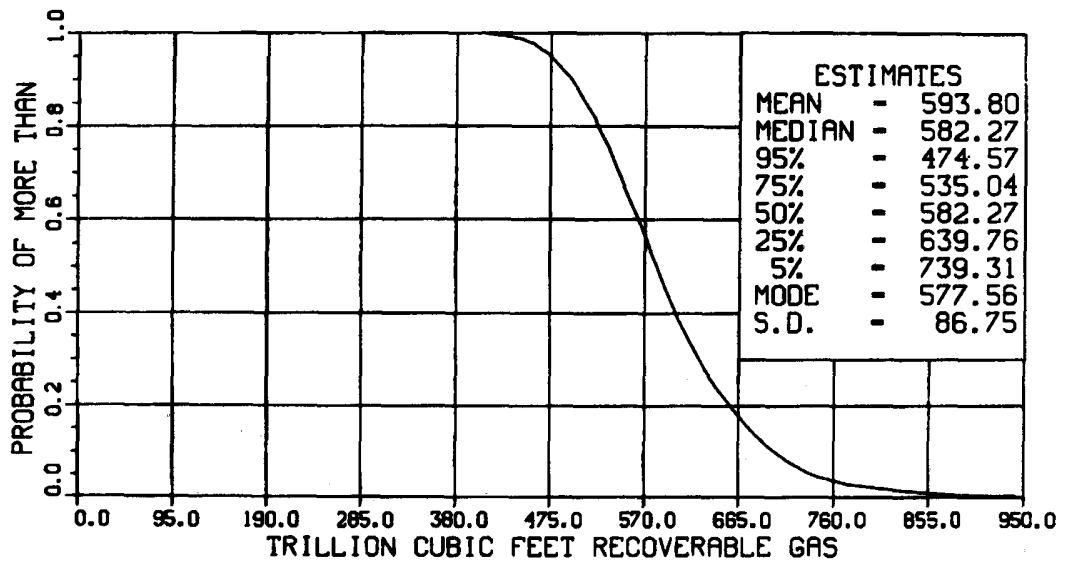

NON-ASSOCIATED GAS

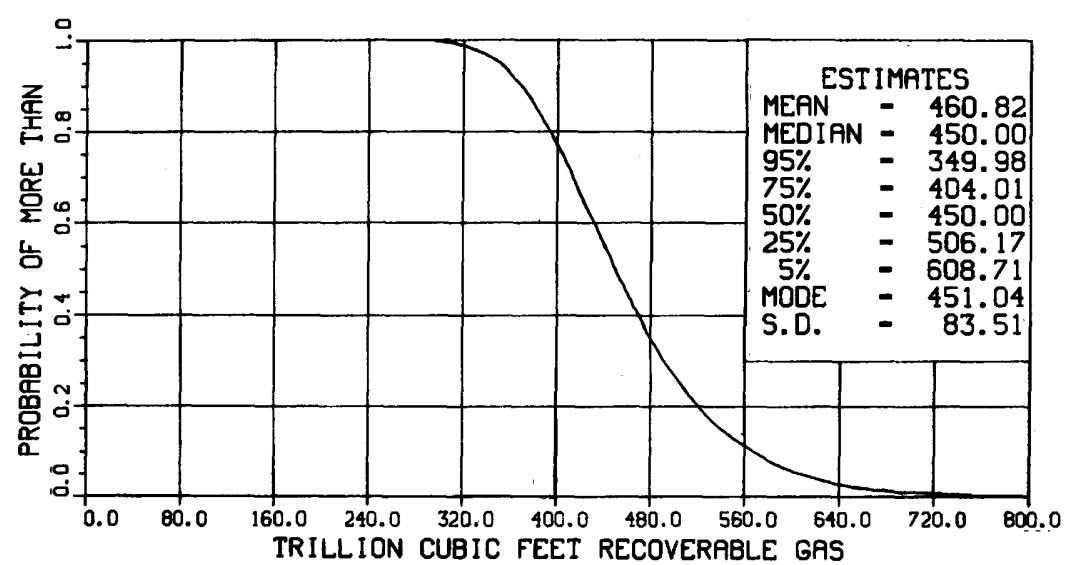

Entire United States 

APPENDIXES B, C, D, AND E 


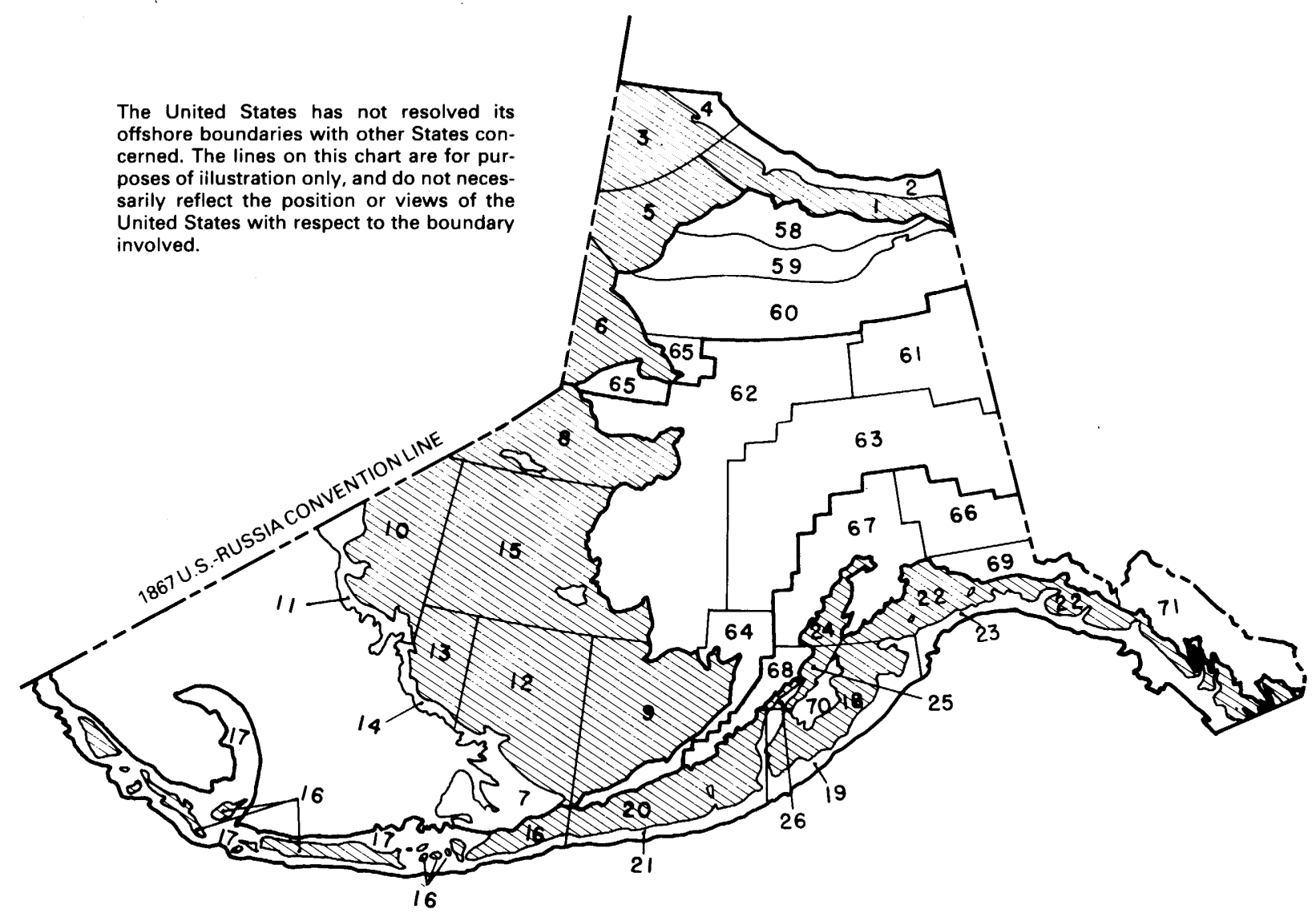

Index map of Alaska showing provinces assessed. Shading denotes offshore shelf areas. Names of onshore provinces are listed numerically in Appendix C. Names of offshore provinces are listed numerically by shelf and by slope in Appendix D. 




Index map of lower 48 States showing provinces assessed. Shading denotes offshore shelf areas. Names of onshore provinces are listed numerically in Appendix C. Names of offshore provinces are listed numerically by shelf and by slope in Appendix D. 
Appendix C

Estimates of undiscovered recoverable oil and gas for onshore provinces in the entire United States.

The following estimates are arranged by Region and province number (see fig. 3 and Appendix B for location). All tabulated values are rounded numbers. Negl., negligible, is less than or equal to 0.05 billion barrels of oil or 0.05 trillion cubic feet of gas. S. D., is standard deviation. $F_{95}$ denotes the $95 \mathrm{th}$ fractile; the probability of more than the amount $\mathrm{F}_{95}$ is 95 percent. $\mathrm{F}_{5}$ is defined similarly. Fractile values are not additive.

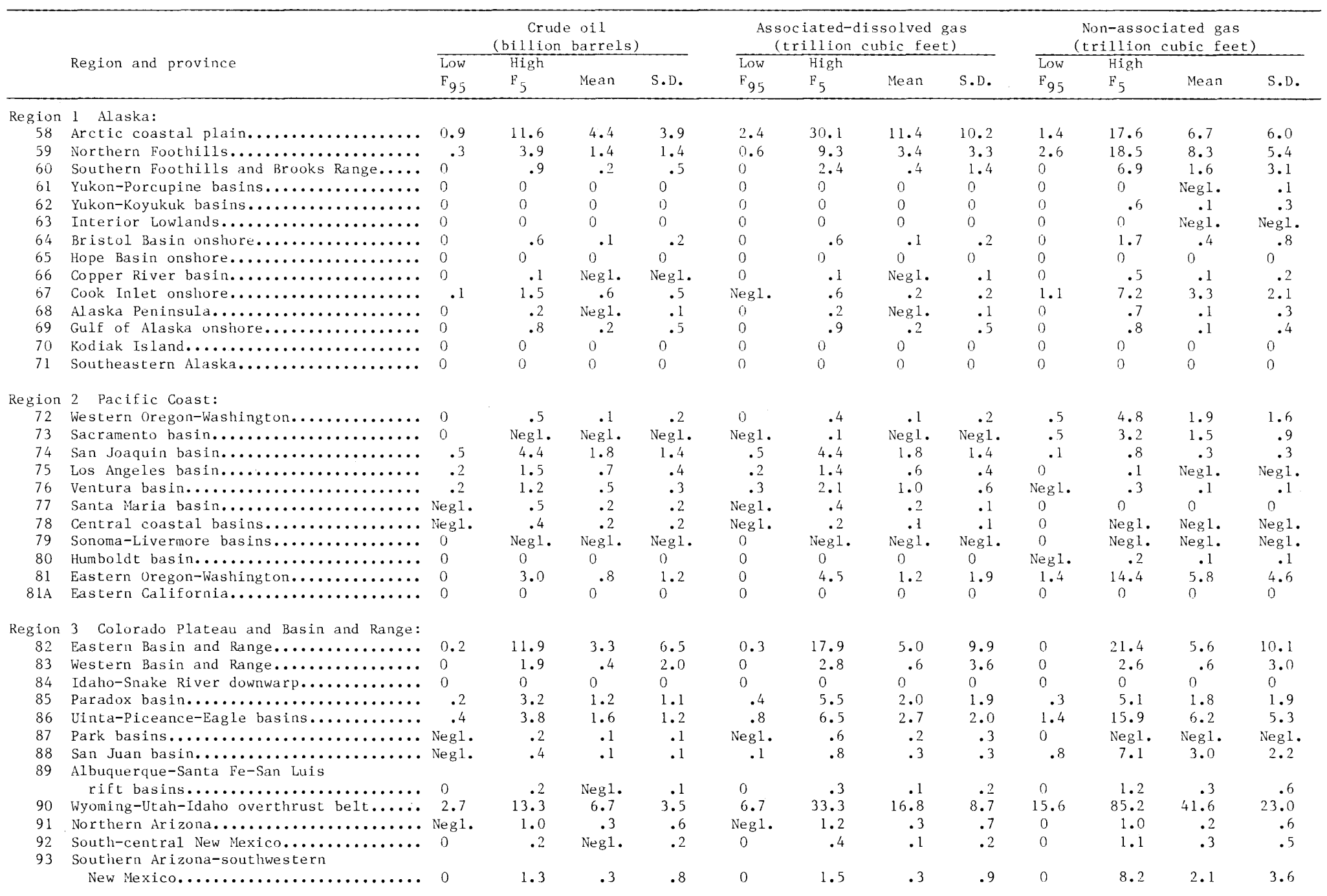


Region 4 Rocky Mountains and Northern Great Plains: 94 williston basin ....................... 0.4 95 Sioux arch................................

96 Sweetgrass arch.........................

97 Central Montana.........................

98 Montana overthrust belt.............. 0

99 Southwestern Montana.................. 0

100 Wind River basin......................

101 Powder River basin....................

102 Southwestern Wyoming basins..............

103 Big Horn basin........................

104 Denver basin.

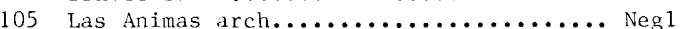

106 Raton Basin-Sierra Grande uplift.......

Region 5 West Texas and eastern New Mexico

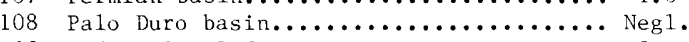

109 Pedernal uplift.........................

110 Bend Arch-Fort Worth basin.............

Region 6 Gulf Coast:

112 Western Gulf basin................. 1.2

113 East Texas basin...................

114 Louisiana-Mississippi sa1t basins...... .8

Region 7 ilid-continent:

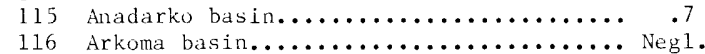

116 Arkoma basin....................... Neg 1.

118 Cherokee platform................... . . .

119 Forest City basin....................... Negl.

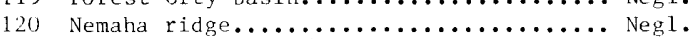

121 Salina basin.......................

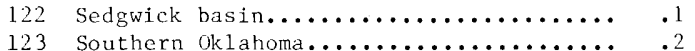

123 Southern ok lahoma $\ldots \ldots \ldots \ldots \ldots \ldots \ldots \ldots \ldots$

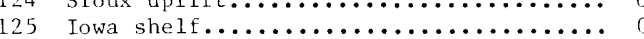

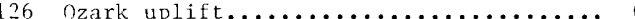

Region 8 Michigan basin:

127 Michigan basin......

Region 9 Eastern Interior:

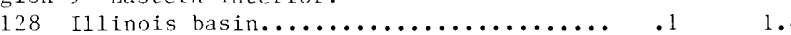

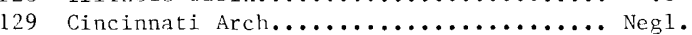

130 Black warrior basin................. Negl.

Region 10 Appalachians:

131 Appalachian basin...................

133 piedmont .............................

134 New England-Adirondack............... 0

Region 11 Atlantic Coast:

135 Atlantic coastal plain................

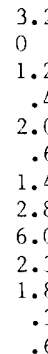

6.2

$\begin{array}{ll}2.9 & 1.7\end{array}$

Neg1. Neg1.

$\begin{array}{lll}4.2 & 2.0 & 1.2\end{array}$

1.7

8.0

2.7

3.6

2.3

5.1
1.0

5.1
1.0
1.0

1.0
1.0
.1

.1
Neg 1.

.6
1.8

0

)

2.7

1. 4

.5
.5

1
0
0
0

0

2.3

1.4

0.8
0
Neg1.
Neg1.
0
0
.1
.8
.9
.2
.2
0
0

5.8

0.4

.2

4.4
.9

.7

6.5

1.6

Neg1.

$$
.6
$$

2.1

0

1.3

12.9

Neg1.

7.5

1.3

3.0

.6

20.0
1.9

4.0

1.6
.1
.1
.1
Neg1.
Neg1.
0
Neg1.
.4
0
0
0

11.9
2.3
.7
2.2
.1
.1
$\operatorname{Neg} 1$.
.4
4.2
0
0
0

$\begin{array}{cc}5.2 & 3.5 \\ .7 & 1.0 \\ .3 & .2 \\ .8 & .8 \\ \text { Negl. } & \text { Neg1. } \\ .1 & \text { Neg1. } \\ \text { Neg1. } & \text { Neg1. } \\ .2 & .1 \\ 1.6 & 1.4 \\ 0 & 0 \\ 0 & 0 \\ 0 & 0\end{array}$

3.6

0.2
0
.6
.1
1.8
0
.7
.1
5.3
.6
.5
.3

1.7
0
6.5
1.6
20.6
.7
4.2
1.2
33.7
3.7
3.1
2.3
1.1

0.8

2.6

.5

8.0
.2

2.0

15.7

1.7

1.4

Negl.

$\begin{array}{lll}6.0 & 3.6 & 9.0\end{array}$

Neg1. Negl. Negl.

27.3

0

1.9

0

9.0
2.9

4.6
.7

0.5

2.1

.6
6.8

. 3

.5

9.0

1.0
.9

.7
.5

17.0

$0^{.2}$

2.3
1.5

62.2

3.8
11.1

0.5
$.529 .5 \quad 17.6$

$\begin{array}{rrrr}.5 & 8.1 & 2.8 & 3.0 \\ .2 & .9 & .4 & .3\end{array}$

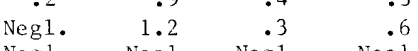

Negl. Negl. Negl. Negl.

0

.2

0

$1.3 \quad .6$

.6
1.8

$0^{.4}$ 
Estimates of undiscovered recoverable oil and gas for offshore provinces in the entire United States.

The following estimates are arranged by shelf and slope; within these two categories the Regions and provinces are listed by number (see fig. 3 and Appendix B for location). All tabulated values are rounded numbers. Neg1., negligible, is less than or equal to 0.05 billion barrels of oil or 0.05 trillion cubic feet of gas. S. D. is standard deviation. F 95 denotes the 95 th fractile; the probability of more than the amount $\mathrm{F}_{95}$ is 95 percent. $F_{5}$ is defined similarly. Fractile values are not additive.

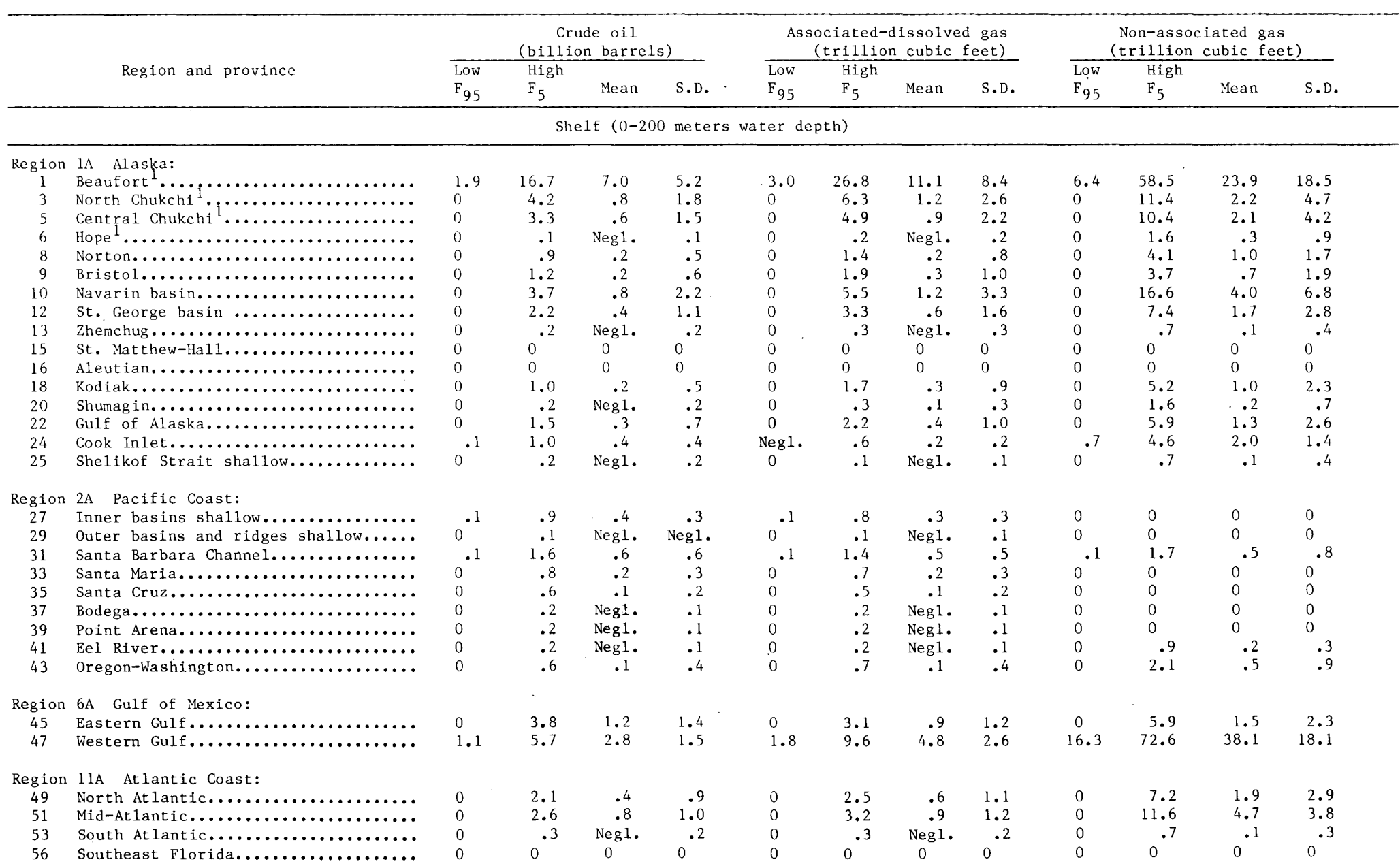


S1ope $(200-2,500$ meters water depth)

\begin{tabular}{|c|c|c|c|c|c|c|c|c|c|c|c|c|c|}
\hline \multicolumn{14}{|c|}{ Region 1A Alaska: } \\
\hline 2 & Beaufort ${ }^{1}, \ldots, \ldots, \ldots, \ldots, \ldots, \ldots, \ldots$ & 0 & 3.6 & 0.8 & 2.0 & 0 & 5.7 & 1.2 & 3.2 & 0 & 12.1 & 3.1 & 11.1 \\
\hline 4 & North Chukchi ${ }^{1} \ldots \ldots \ldots \ldots \ldots \ldots \ldots \ldots$ & 0 & 1.1 & .2 & .6 & 0 & 1.7 & .3 & .9 & 0 & 3.2 & .8 & 3.3 \\
\hline 7 & Umnak Plateau......................... & 0 & 0 & 0 & 0 & 0 & 0 & 0 & 0 & 0 & 0 & 0 & 0 \\
\hline 11 & Navarin basin..$\ldots \ldots \ldots \ldots \ldots \ldots \ldots$ & 0 & .6 & .1 & .3 & 0 & 1.0 & .1 & .4 & 0 & 1.8 & .3 & .8 \\
\hline 14 & Zhemchug $. \ldots \ldots \ldots \ldots \ldots \ldots \ldots \ldots \ldots, \ldots$ & 0 & 0 & 0 & 0 & 0 & 0 & 0 & 0 & 0 & 0 & 0 & 0 \\
\hline 17 & Aleutian........................... & 0 & 0 & 0 & 0 & 0 & 0 & 0 & 0 & 0 & 0 & 0 & 0 \\
\hline 19 & 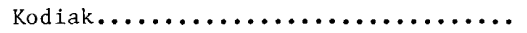 & 0 & 1.0 & .2 & .8 & 0 & 1.8 & .3 & 1.4 & 0 & 2.1 & .4 & 1.2 \\
\hline 21 & Shumagin $. \ldots, \ldots, \ldots, \ldots, \ldots, \ldots, \ldots$ & 0 & .2 & Negl. & .2 & 0 & .3 & .1 & .4 & 0 & 1.6 & .2 & .8 \\
\hline 23 & 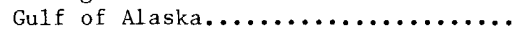 & 0 & .7 & .1 & .4 & 0 & 1.0 & .2 & .6 & 0 & 1.7 & .3 & .8 \\
\hline 26 & Shelikof Strait deep $. . . \ldots \ldots \ldots \ldots . .$. & 0 & 0 & Negl. & Negl. & 0 & 0 & Negl. & Negl. & 0 & 0 & Neg1. & Neg1. \\
\hline \multicolumn{14}{|c|}{ Region 2A Pacific Coast } \\
\hline 28 & Inner basins deep..$\ldots \ldots \ldots \ldots \ldots \ldots$ & 0 & 1.0 & .2 & .5 & 0 & .9 & .2 & .5 & 0 & 0 & 0 & 0 \\
\hline 30 & Outer basins and ridges deep..$\ldots \ldots \ldots$ & 0 & 2.5 & .5 & 1.1 & 0 & 3.7 & .8 & 1.7 & 0 & .7 & .1 & .5 \\
\hline 32 & Santa Barbara Channel deep............. & .1 & 2.1 & .7 & .8 & .1 & 2.5 & .8 & 1.0 & 0 & 1.9 & .7 & .8 \\
\hline 34 & Santa Maria $. \ldots, \ldots \ldots \ldots, \ldots, \ldots, \ldots$ & 0 & 2.2 & .5 & 1.1 & 0 & 2.0 & .4 & 1.0 & 0 & 0 & 0 & 0 \\
\hline 36 & Santa Cruz.......................... & 0 & .5 & .1 & .3 & 0 & .4 & .1 & .3 & 0 & 0 & 0 & 0 \\
\hline 38 & Bodega $. \ldots \ldots \ldots \ldots \ldots \ldots \ldots \ldots \ldots \ldots, \ldots$ & 0 & .2 & Negi. & .1 & 0 & .1 & Neg1. & .1 & 0 & 0 & 0 & 0 \\
\hline 40 & Point Arena........................... & 0 & .4 & .1 & .2 & 0 & .3 & Negl. & .2 & 0 & 0 & 0 & 0 \\
\hline 42 & Eel River $\ldots \ldots \ldots \ldots \ldots \ldots \ldots \ldots \ldots$ & 0 & .2 & Negl. & .2 & 0 & .3 & Negl. & .2 & 0 & 1.2 & .3 & .5 \\
\hline 44 & Oregon-Washington.................. & 0 & 1.3 & .2 & .6 & 0 & 1.6 & .3 & .7 & 0 & 3.0 & .6 & 1.4 \\
\hline \multicolumn{14}{|c|}{ Region 6A Gulf of Mexico: } \\
\hline 46 & Eastern Gulf $\ldots \ldots \ldots \ldots \ldots \ldots \ldots, \ldots$ & 0 & 1.0 & .2 & .4 & 0 & .8 & .2 & .3 & 0 & 1.8 & .3 & .8 \\
\hline 48 & Western Gulf...$\ldots \ldots \ldots \ldots \ldots \ldots \ldots$ & .9 & 4.8 & 2.4 & 1.3 & 1.6 & 8.7 & 4.2 & 2.4 & 7.2 & 47.6 & 21.9 & 13.6 \\
\hline \multicolumn{14}{|c|}{ Region llA At lantic Coast: } \\
\hline 50 & North Atlantic $\ldots \ldots \ldots \ldots \ldots \ldots \ldots \ldots$ & 0 & 3.8 & 1.0 & 1.6 & 0 & 4.6 & 1.1 & 1.9 & 0 & 7.9 & 2.1 & 3.3 \\
\hline 52 & Mid-At1antic $\ldots \ldots \ldots \ldots \ldots \ldots \ldots \ldots \ldots$ & 0 & 7.6 & 2.3 & 2.8 & 0 & 9.1 & 2.7 & 3.4 & 0 & 17.8 & 5.9 & 6.5 \\
\hline 54 & Carolina trough...$\ldots \ldots \ldots \ldots \ldots \ldots$ & 0 & 3.0 & .6 & 1.4 & 0 & 3.3 & .7 & 1.6 & 0 & 9.6 & 2.1 & 4.5 \\
\hline 55 & 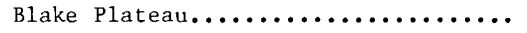 & 0 & 1.7 & .3 & .7 & 0 & 1.7 & .3 & .7 & 0 & 2.4 & .4 & 1.3 \\
\hline 57 & Florida Straits.......................... & 0 & 0 & 0 & 0 & 0 & 0 & 0 & 0 & 0 & 0 & 0 & 0 \\
\hline
\end{tabular}

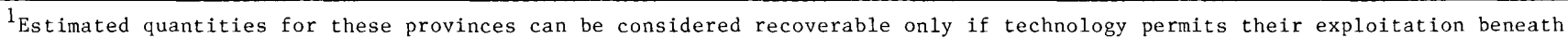

Arctic pack ice--a condition not yet met. 
Estimated Federal ownership of oil and gas resources

The percent of undiscovered recoverable oil and gas resources listed below are for those resources estimated to occur offshore under Federal waters and onshore on non-Indian Federal lands and on patented lands with Federally reserved oil and gas rights. Alaska is not included because land ownership there has not been completely determined. All values are rounded to the nearest 5 percent. Neg1., negligible, is less than 2.5 percent.

\begin{tabular}{|c|c|c|c|}
\hline & Region & $\frac{\text { Percent Federal }}{\text { Oil }}$ & $\frac{\text { Ownership }}{\text { Gas }}$ \\
\hline \multicolumn{4}{|c|}{ Offshore $(0-2500 \mathrm{~m})$ : } \\
\hline $2 \mathrm{~A}$ & 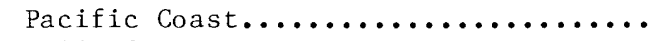 & 85 & 90 \\
\hline & Gulf of Mexico................ & 95 & 95 \\
\hline $11 \mathrm{~A}$ & 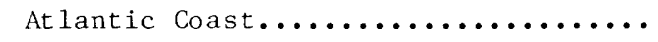 & 100 & 100 \\
\hline Entir & Le Lower 48 States offshore.......... & 95 & 95 \\
\hline \multicolumn{4}{|l|}{ Onshore: } \\
\hline $2 \mathrm{~F}$ & 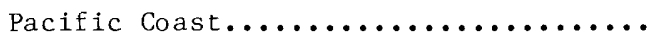 & 10 & 25 \\
\hline $3 c$ & Colorado Plateau and & & \\
\hline & 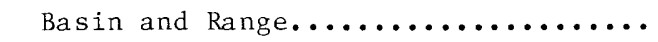 & 70 & 70 \\
\hline $4 \mathrm{~B}$ & Rocky Mountains and & & \\
\hline & northern Great Plains............ & 50 & 55 \\
\hline $5 \mathrm{~h}$ & West Texas and eastern & & \\
\hline & 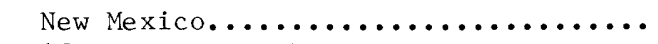 & 5 & 5 \\
\hline 6 & 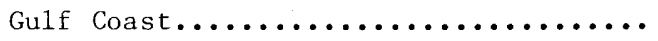 & Neg 1 . & Neg1. \\
\hline 7 & 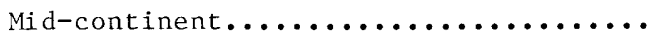 & Negl. & Neg1. \\
\hline $8 x$ & 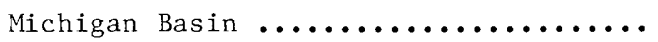 & 5 & 5 \\
\hline $9 \mathrm{H}$ & 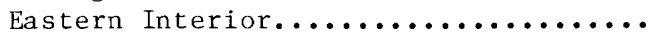 & Neg1. & Neg1. \\
\hline $10 \mathrm{~A}$ & 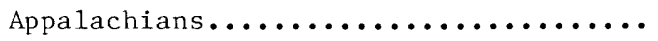 & 5 & 5 \\
\hline $11 A$ & At lantic Coast $\ldots \ldots \ldots \ldots \ldots \ldots \ldots$ & 10 & 5 \\
\hline Lower & 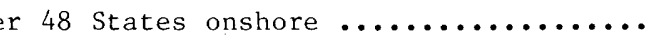 & 30 & 25 \\
\hline
\end{tabular}

${ }^{1}$ Percent of mean resource estimate. 


\section{APPENDIX F}

Estimation of inferred plus indicated reserves for the United States, By D. H. Root 


\section{ILLUSTRATIONS}

Page

Figures F1-F4.--Graphs showing:

F1.--Projected total growth of estimates of the amount

of ultimately recoverable crude oil in fields

discovered before 1979 in the conterminous

United States versus the number of years of

data used...............................

F2.--The growth of estimates of the amount of recoverable oil discovered in a given year in the conterminous United States versus the number of years after the

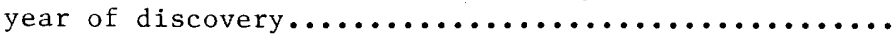

F3.--The growth of estimates of the amount of recoverable natural gas discovered in a given year in the conterminous United States versus the number of

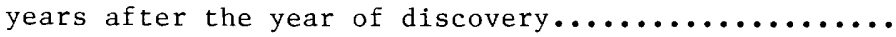

F4.--Projected total growth in estimates of the amount of ultimately recoverable natural gas in fields discovered before 1979 in the conterminous United States versus the number of years of data used...............................

TABLES

Table F1.--Estimated inferred plus indicated reserves of crude oil in fields discovered in the United States exclusive of

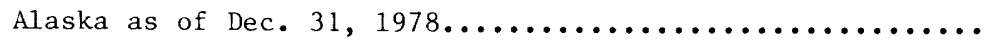

F2.--Estimated inferred reserves of natural gas in fields discovered in the United States exclusive of Alaska as of

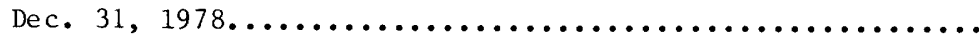




\title{
Estimation of Inferred Plus Indicated Reserves for the United States
}

\author{
By D. H. Root
}

Estimates of the amounts of crude oil and natural gas discovered in the United States and Canada are published by the American Petroleum Institute, the American Gas Association and the Canadian Petroleum Association (API, AGA, and CPA). These estimates have been updated annually since 1967 (API and others, 19671979). Ultimate recovery (defined as past production plus proved reserves) of oil or gas in fields discovered in a given year usually increases from one estimate to the next. Increases are proportionately larger for younger discoveries than for older discoveries.

The changes in estimates of the amounts of oil and gas discovered in a given year could be due to several reasons: (1) drilling could prove that some fields were larger or smaller than had been thought, (2) production experience could indicate that the assumed recovery factors were too high or too low, (3) application of improved recovery techniques could change the anticipated crude-oil recovery, (4) a field could be reported to the reserves committee for the first time several years after its discovery, (5) the discovery year assigned to a field could be changed which would shift the estimate of the field's oil or gas to another discovery year, and (6) new producing zones could be found in an old field.

The phenomenon of growth in estimates of the amount of oil and gas has been studied by many authors (Arrington, 1960; Hubbert, 1974; Marsh, 1971; Mast and Dingler, 1975; Pelto, 1973; and White and others, 1975) in an effort to estimate what future increases could be expected. Methods and data used by those authors to estimate future additions to proved reserves from growth of past discoveries are similar to those used here.

The future growth of estimates of ultimate recovery from fields discovered before 1979 is estimated here under the assumptions that (1) when a field has been known for 59 years, its estimated ultimate recovery will no longer change, and (2) estimates of recoverable oil and gas in recently discovered fields will show the same percentage growth with similar age as do estimates for fields that were discovered years ago. Annual data (API and others, 1967-1979) go back only to 1920; hence, the choice of 59 years in assumption "1." Although this petroleum data series began in 1967 (API and others, 1967), only those books for the years 1971 through 1978 were used to estimate growth factors for recoverable oil. The length of the data series used has an effect on the estimated future growth. Figure $\mathrm{Fl}$ shows how varying the number of years of data changes the estimated future additions to reserves from pre-1979 fields. Use of 1971 through 1978 data gives an average amount of growth.

The growth remaining in the fields discovered in a given year is calculated by estimating the expected percentage growth for each year of aging until the fields become 59 years old and then accumulating the 1-year growth factors. The calculation of the amount of growth from the first to the second estimate serves as an example. Several estimates of ultimate recovery are available for oil fields discovered in the years 1971 through 1977; they

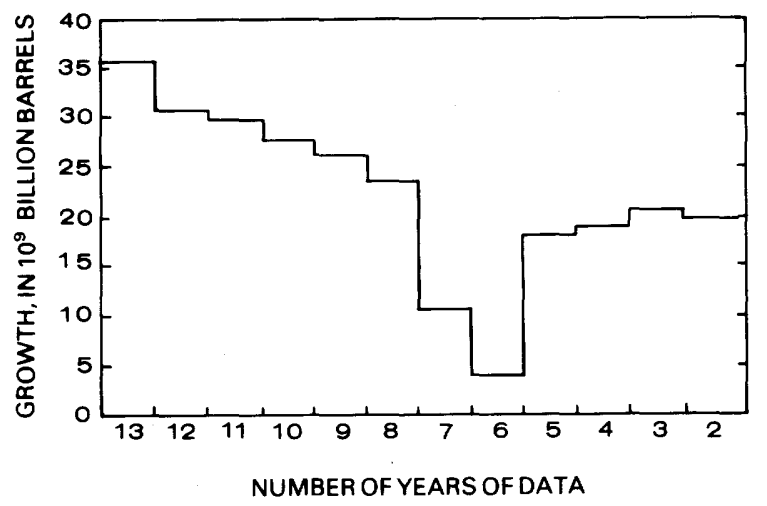

Figure F1.--Projected total growth of estimates of the amount of ultimately recoverable crude oil in fields discovered before 1979 in the conterminous United States versus the number of years of data used. Thirteen years of data are from 1966 to 1978; two years of data are from 1977 to 1978 (American Petroleum Institute and others 1967-1979). 
include estimates made at the end of the year of their discovery and estimates made 1 year after that. From these estimates, the expected percentage increase between the first and second estimate can be calculated. Let $w(i, j)$ be the estimate as of the end of year $j$ of recoverable oil in all fields discovered during year $i$. The estimated 1-year growth factor from the first to the second estimate is then given by the ratio

$$
\frac{i=\frac{1971}{1977} w(i, i+1)}{i=1977} w(i, i)
$$

In genera1, the estimated 1-year growth factor from the $n-1$ year estimate to the nth year estimate is given by

$$
\frac{\sum_{\text {max }}^{1978-n} w(i, i+n)}{i=\operatorname{mof} 1972-n, 1919}=r(n)
$$

For the purposes of these calculations, a11 fields discovered before 1920 were credited to 1919. The amount by which the estimate of the recoverable oil discovered in the conterminous United States in a given year is expected to increase is obtained by multiplying the 1978 estimated ultimate recovery estimate by all the $r(n)$ from equation (2) where $n$ is greater than the difference between 1978 and the discovery year and is less than 60. The growth factor for an estimate as of Dec. 31, 1978 of recoverable

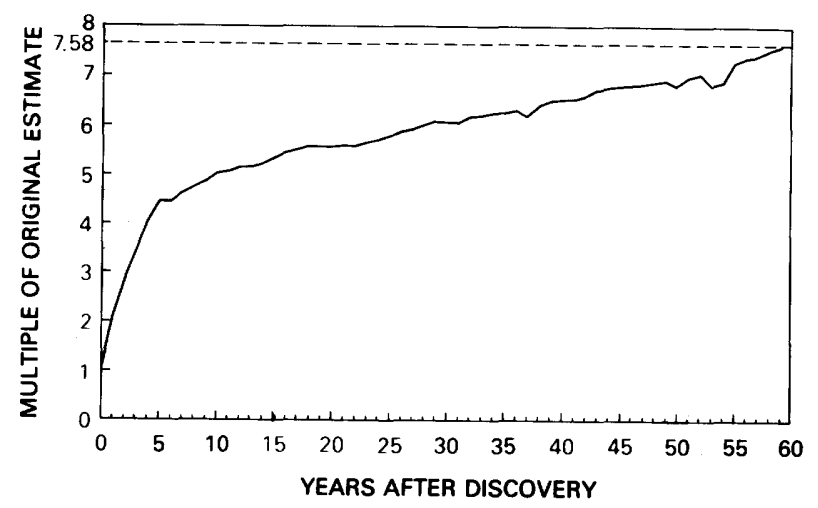

Figure F2.--The growth of estimates of the amount of recoverable oil discovered in a given year in the conterminous United States versus the number of years after the year of discovery. Data from the American Petroleum Institute and others (1972-1979, v. 26 through 33). oil in fields discovered $n-1$ years ago as of Dec. 31, 1978 is given by $R(n)$, the product of a11 the 1-year growth factors, $r(i)$ where $i$ is greater than $\mathrm{n}-1$.

$$
R(n)=\prod_{i=n}^{59} r(i)
$$

Figure F2 shows how the estimate of recoverable oil discovered in a given year in the conterminous United States is projected to increase from its first estimate to its fiftyninth estimate. Similar growth curves can be calculated for individual reporting areas. The estimated known ultimate production from known oil fields (including growth) was calculated by applying the growth factors for each reporting area to the corresponding oil-discovery data. The estimated inferred and indicated reserves are derived from these figures by subtraction of API cumulative production and proved reserves. The results of the individual State calculations are presented in table F1. Note that the sum of the State estimates differs somewhat from the estimate calculated for the conterminous United States as a whole.

The American Gas Association estimates of the amount of natural gas discovered in the United States are divided by geographic location, year of discovery, and whether the gas is associated with crude oil or not (API and others, 1967-1979). Growth factors for natural gas were calculated in the same manner as for oil. In addition to the growth factors calculated for total natural gas (fig. F3), individual growth factors for associated and non-associated natural gas also were calculated. Calculations indicated that most of the growth in natural gas is expected to be in non-associated gas; not much growth in associated gas. Because trends in natural gas

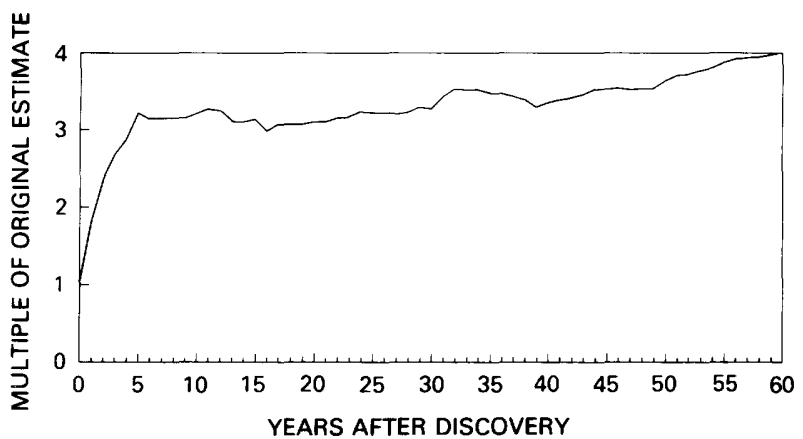

Figure F3.--The growth of estimates of the amount of recoverable natural gas discoverd in a given year in the conterminous United States versus the number of years after the year of discovery. Data from the American Petroleum Institute and others (1971-1979, v. 25 through 33). 
Table F-1.--Tstimated inferred plus indicated reserves of crude oil in fields discovered in the United States exclusive of Alaska as of Dec. 31, 1978

[Tabulated values are compiled from American Petroleum Institute data (American Petroleum Institute and others, 1967-1979). Values shown are in thousand barrels. Asterisk, *, indicates that the offshore is included]

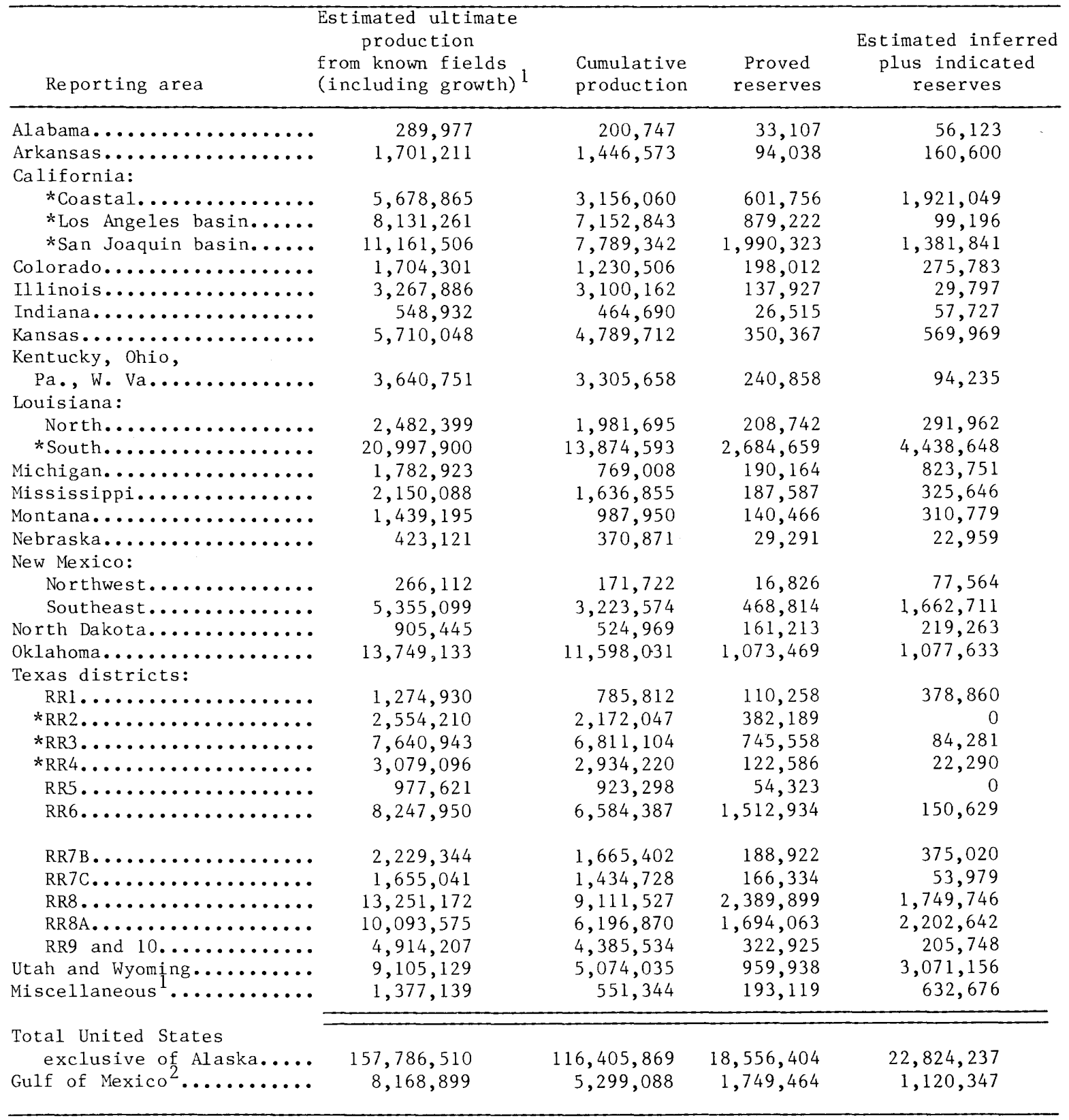

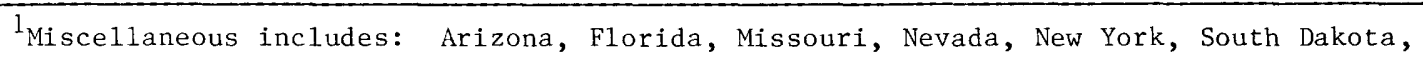
Tennesse, Virginia, and Washington.

${ }^{2}$ Gulf of Mexico offshore is included in Texas and Louisiana above, but is also 1 isted as separate entry here to be consistent with American Petroleum Institute practice. 
Table F-2.--Estimated inferred reserves of natural gas in fields discovered in the United States exclusive of Alaska as of Dec. 31, 1978

[Tabulated values are compiled from American Gas Association data (American Petroleum Institute and others, 1967-1979). Values shown are in million cubic feet. Asterisk, *, indicates that the offshore is included]

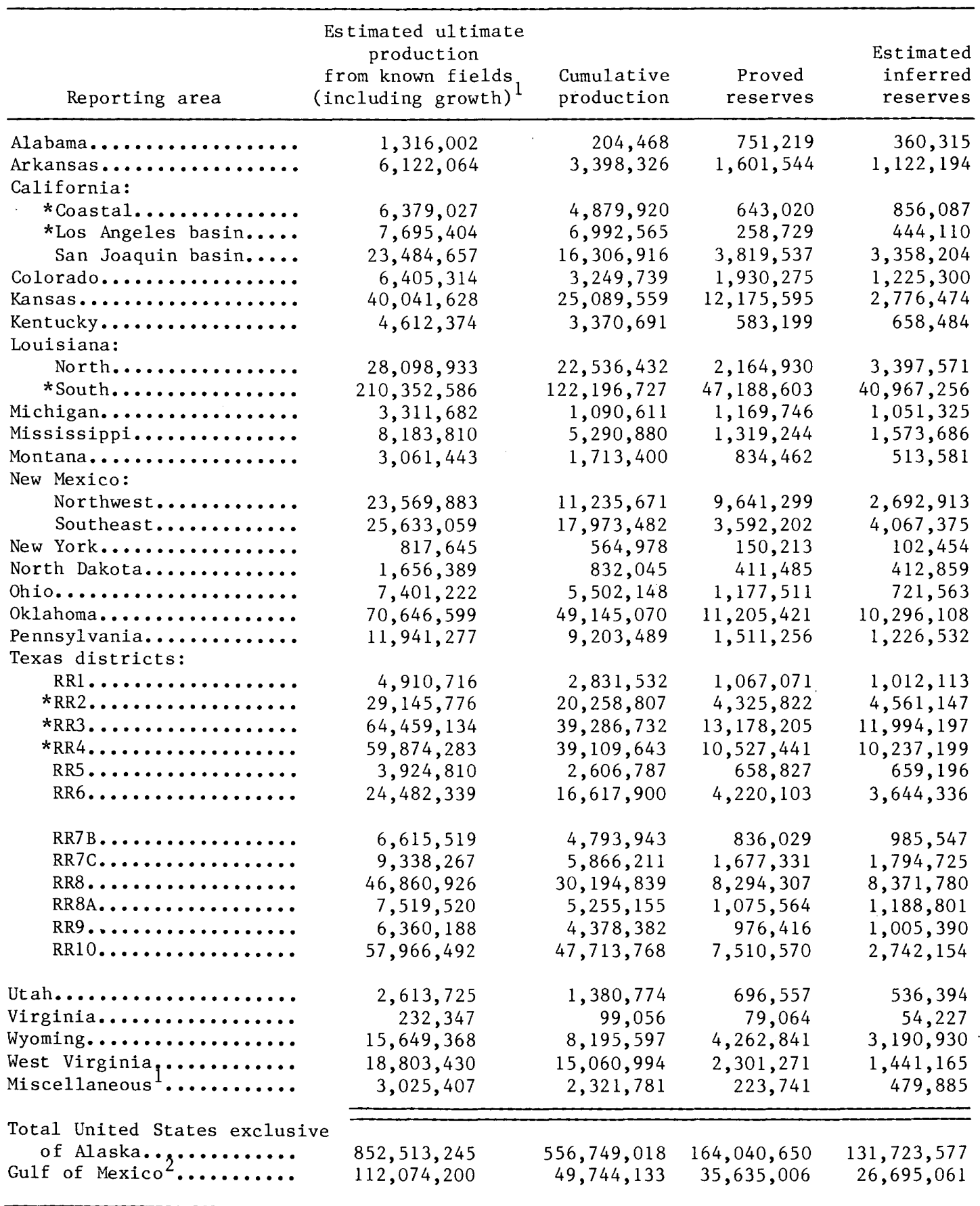

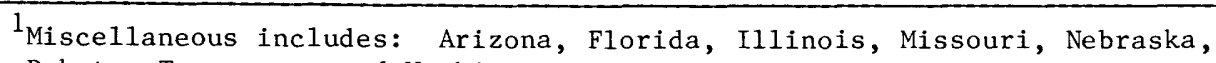
South Dakota, Tennessee, and Washington.

${ }^{2}$ Gulf of Mexico offshore is included in Texas and Louisiana above, but is also listed as a separate entry here to be consistent with American Petroleum Institute practice. 


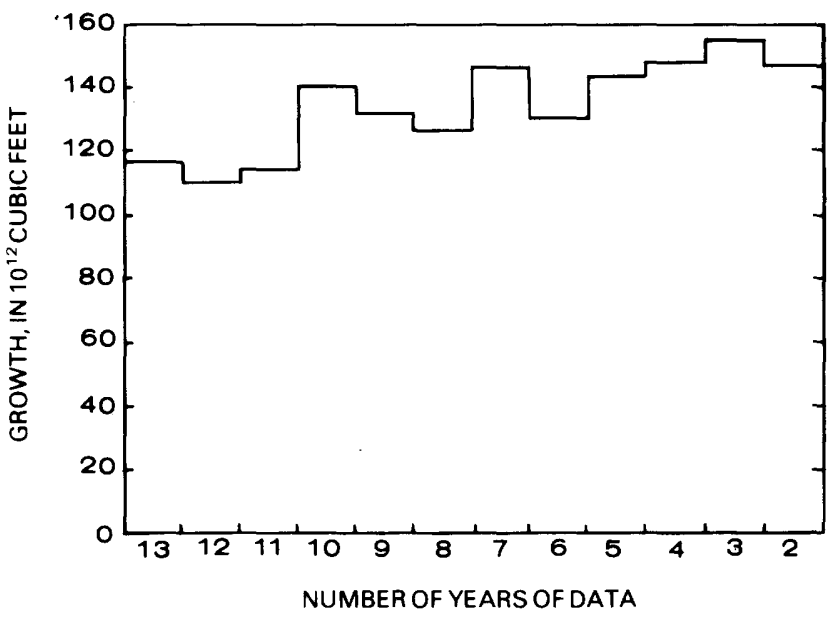

Figure F4.--Projected total growth in estimates of the amount of ultimately recoverable natural gas in fields discovered before 1979 in the conterminous United States versus the number of years of data used. Thirteen years of data are from 1966 to 1978 ; two years of data are from 1977 to 1978 (American Petroleum Institute and others, 1967-1979).

data are too erratic to permit the calculation of growth factors on a State by State basis, the table of inferred reserves for the States (table F2) was calculated by applying the growth factors calculated for the conterminous United States as a whole to the State natural-gas discovery data. The growth curve (fig. F4) for recoverable natural gas was calculated by the same method that was used for recoverable oil, except that for gas, nine years of data--19701978--were used instead of eight. Figure F4 shows how varying the length of the data series changes the estimate of growth of gas reserves. Again, the length of the data series was chosen to give an average amount of growth. Inferred reserves for natural gas were calculated in a manner similar to that for oil. For both oil and gas, the growth factors were calculated for a particular data series, and to apply the factors to another data series, for example, to individual field data, would be inappropriate. Late reporting of discoveries probably is responsible for much of the apparent growth in the first two or three years after discovery. If this is true, then those fields that have been reported grow much less than the calculated growth curves might at first lead one to believe.

\section{REFERENCES CITED}

American Petroleum Institute, American Gas Association, and Canadian Petroleum Association, 1967-1979, Reserves of crude oil, natural gas liquids, and natural gas in the United States and Canada [annual volumes for the years 1966-1978]: New York, American Petroleum Institute.

Arrington, J. R., 1960, Size of crude reserves is key to evaluating exploration programs: $0 i 1$ and Gas Journal, v. 58, no. 9, Feb. 29, p. 130-134.

Hubbert, M. K., 1974, U.S. energy resources, a review as of 1972 , pt. 1, in A national fuels and energy policy study: U.S. 93rd. Congress, $2 \mathrm{~d}$ session, Senate Committee on Interior and Insular Affairs, Committee Print, Serial No. 93-40 (92-75), 267 p.

Marsh, G. R., 1971, How much oil are we really finding: Oil and Gas Journal, v. 69, no. 14, Apri1 5, p. 100-104.

Mast, R. F., and Dingler, Janet, 1975, Estimates of inferred + indicated reserves for the United States, in Miller, B. M., Thomsen, H. L., Dolton, G. L., Coury, A. B., Hendricks, T. A., Lennartz, F. E., Powers, R. B., Sable, E. G., and Varnes, K. L., Geological estimates of undiscovered recoverable oil and gas resources in the United States: U.S. Geological Survey Circular 725, p. 73-78.

Pelto, C. R., 1973, Forecasting ultimate oil recovery, in symposium on petroleum economics and evaluation: Society of Petroleum Engineers, American Institute of Mining and Metallurgical Engineers, Dallas section, SPE 4261, p. 45-52.

White, D. A., Garrett, R. W., Jr., Marsh, G. R., Baker, R. A., and Gehman, H. M., 1975, Assessing regional oil and gas potential, in Haun, J. D., ed., Methods of estimating the volume of undiscovered oil and gas resources: American Association of Petroleum Geologists, Studies in geology, no. 1, p. 143-159. 
